\title{
EVANDRO FIORIN
}

\section{Arquitetura paulista: do modelo à miragem}

Tese apresentada à Faculdade de Arquitetura e Urbanismo da Universidade de São Paulo para obtenção do título de Doutor em Arquitetura e Urbanismo.

Área de Concentração: Projeto, Espaço e Cultura

Orientadora: Profa. Dra. Vera Maria Pallamin 


\section{FOLHA DEAPROVAÇÃO}

Evandro Fiorin

Arquitetura paulista: do modelo à miragem

Tese apresentada à Faculdade de Arquitetura e Urbanismo da Universidade de São Paulo para obtenção do título de Doutor em Arquitetura e Urbanismo.

Área de Concentração: Projeto, Espaço e Cultura.

Aprovado em:

Banca Examinadora:

Prof. Dr.

Instituição:

Assinatura:

Prof. Dr.

Instituição:

Assinatura:

Prof. Dr.

Instituição:

Assinatura:

Prof. Dr.

Instituição:

Assinatura:

Prof. Dr.

Instituição: Assinatura: 
Para minha avó Zelinda (in memorian). 


\section{AGRADECIMENTOS}

À minha orientadora Prof. ${ }^{a}$ Dr. ${ }^{a}$ Vera Maria Pallamin pela oportunidade, confiança depositada e respeito a este trabalho, embora não se alinhe com os argumentos aqui defendidos.

À UNIFEV - Centro Universitário de Votuporanga-SP, pelo auxílio docente concedido para a realização dessa tese.

Aos docentes: Lucrécia D’Aléssio Ferrara, Luis Antonio Jorge, Paulo J. V. Bruna, Lucio G. Machado, Mônica J. de Camargo, Celso M. Lamparelli, Maria R. A. de Sampaio, José T. C. de Lira, Cibele S. Rizek e Luiz A. Recamán. Aos colegas e funcionários da FAU/Maranhão. À minha esposa Arlete, companheira de idéias para sempre. Ao meu filho Enrico, pelo ânimo e à Paula, pelo cuidado com ele.

À minha grande família e agregados, em especial, minha mãe, meu pai, meus avós e ao meu irmão Eliel, pelo apoio.

Aos docentes da UNIFEV, especialmente ao casal André e Júlia, pela ajuda, aos funcionários, sobretudo, ao Francisco Alves da Silva Jr., aos alunos e orientandos.

Aos docentes, funcionários e alunos das Faculdades Integradas D. Pedro II de São José do Rio

Preto-SP.

À Lúcia Lima Polacchini, pelas gentilezas. Ao casal Osny e Mara pela cooperação.

A todos que colaboraram para que esse trabalho pudesse ser realizado. Uma tarefa solitária, penosa, de dramas e recompensas pessoais, que esperamo s poder render alguma contribuição. 
"Como se pode lutar por uma nova arquitetura sem fazer nenhuma?"

João Batista Vilanova Artigas, 1980. 


\section{RESUMO}

FIORIN, Evandro. Arquitetura paulista: do modelo à miragem 2009. Tese (Doutorado em Arquitetura) - Faculdade de Arquitetura e Urbanismo, Universidade de São Paulo, São Paulo, 2009. $190 \mathrm{f}$.

Esta tese parte da atitude crítica do arquiteto Vilanova Artigas diante das contradições da década de 1950 para compreender, por meio de algumas obras, sua contribuição política na constituição de uma promessa coletiva para a arquitetura. Um modelo consubstanciado num projeto de progresso econômico e social, mas que, frente à crise desenvolvimentista dos anos 70, deixa ver seu fundo falso, revelando um desígnio às avessas. A partir daí, a técnica passa a ser álibi em trabalhos de arquitetos como Paulo Mendes da Rocha, pois o que se observa é o abrandamento dos embates no âmbito do projeto arquitetônico para alterar a dura realidade brasileira, caracterizando o que chamamos de um encastelamento estético e político da arquitetura. Assim, nos anos 90, em face das desigualdades sociais e das condições materiais e tecnológicas desfavoráveis do país, obras emblemáticas de arquitetos paulistas se apropriam de uma linguagem convalidada na década de 60 , porém se esvaziam de sentido político crítico, sendo entendidas, portanto, como imagens de si mesmas.

Palavras-chave: Arquitetura moderna - São Paulo(SP). Projeto de aquitetura. Arquitetura paulista. 


\begin{abstract}
FIORIN, Evandro. São Paulo architecture: from the model to the mirage. 2009. Thesis (Doctorate in Architecture) - School of Architecture and Urbanism, University of São Paulo, São Paulo, 2009. 190 p.

The starting point of this thesis is the critical attitude of the architect, Vilanova Artigas, in the face of the contradictions of the 50's, and to understand, by the study of some his projects, his political contribution for the constitution of a collective promise to architecture. A model consubstantiated to a social and economic progress project, but, which, in view of the developmentalist crisis of the 70's, lets the fake backdrop be seen, revealing an opposing plan. From this point onwards, the technique becomes an alibi in the work of architects such as Paulo Mendes da Rocha, since what is observed is the appeasement of the assaults on the extent of the architectural project to alter the hard Brazilian reality, characterizing what we call an aesthetic and political enclosure within the walls of architecture. Therefore, in the 90 's, in view of social inequality and the country's unfavorable technological and material conditions, representative projects by São Paulo architects assume a language based on the 60 's, however, they are now devoid of political critical meaning, thus being perceived as images of themselves.
\end{abstract}

Keywords: Modern architecture - São Paulo(SP). Architectural project. São Paulo architecture. 


\section{LISTA DE FIGURAS}

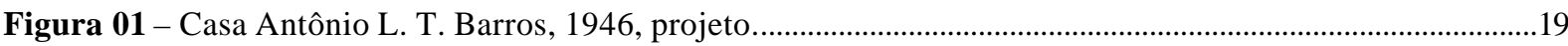

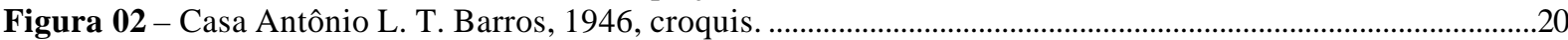

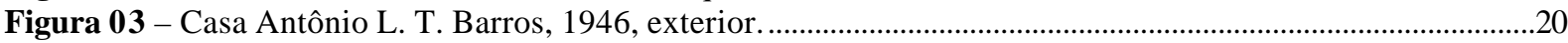

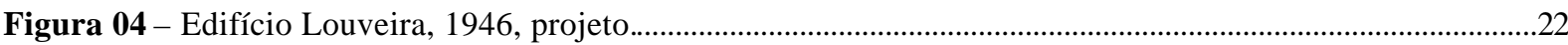

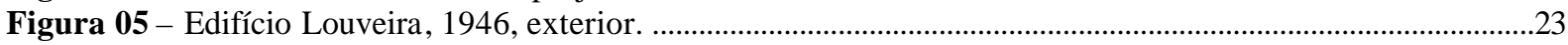

Figura 06 e 07 - Edifício Louveira, 1946, detalhe ..................................................................................................23

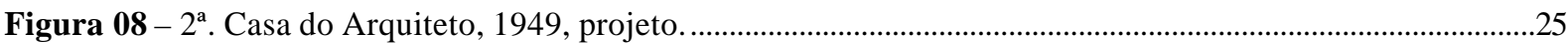

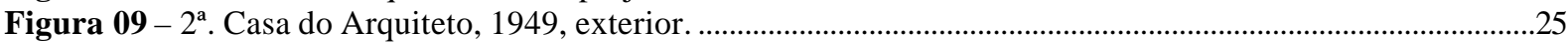

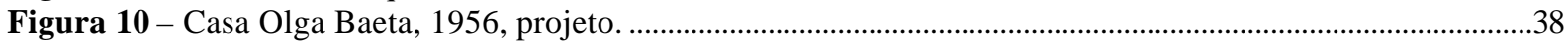

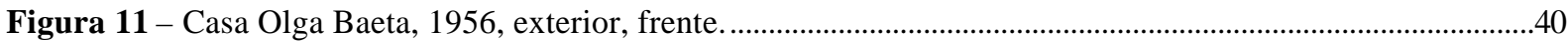

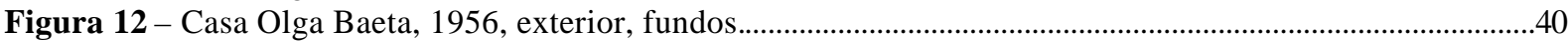

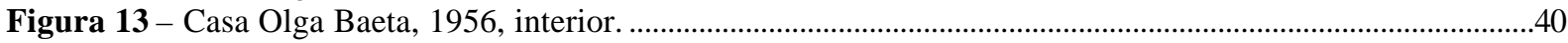

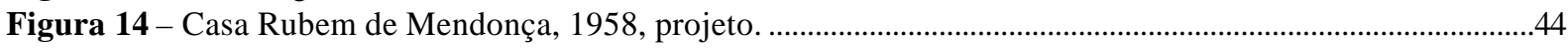

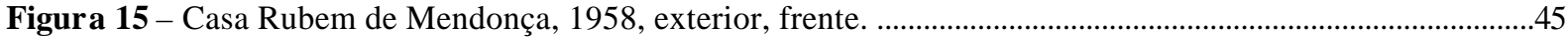

Figura 16 - Casa Rubem de Mendonça, 1958, exterior, fundos............................................................................45

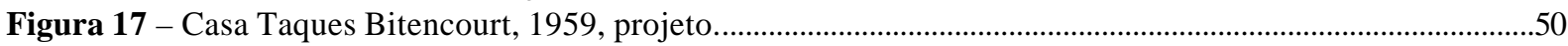

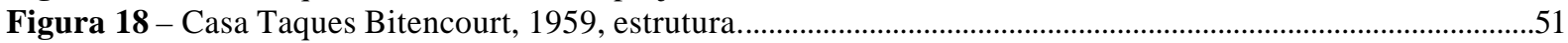

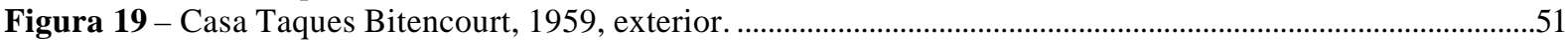

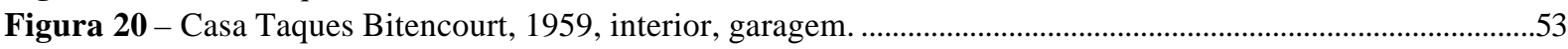

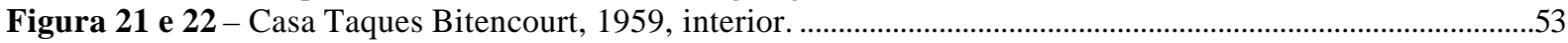

Figura 23 - Ginásio de Itanhaem, 1959, projeto. ................................................................................................56

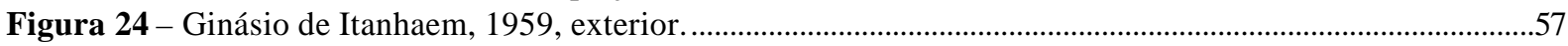

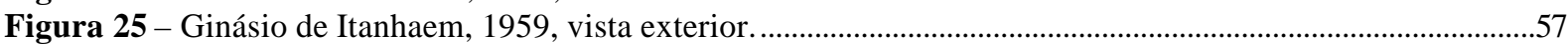

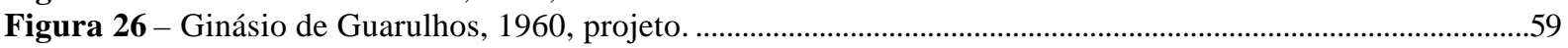

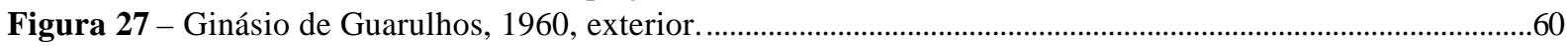

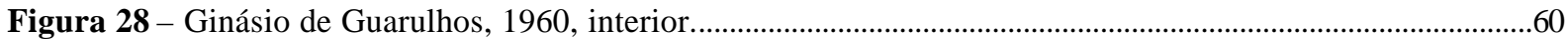

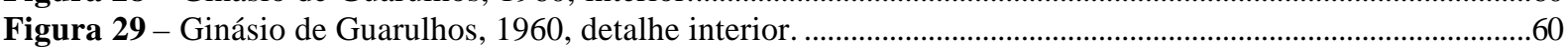

Figura 30 - Faculdade de Arquitetura e Urbanismo da Universidade de São Paulo, 1961, construção..................62

Figura 31 - Faculdade de Arquitetura e Urbanismo da Universidade de São Paulo, 1961, exterior. ......................63

Figura 32 - Faculdade de Arquitetura e Urbanismo da Universidade de São Paulo, 1961, interior. ......................63

Figura 33 e 34 - Xilogravura, Feininger, 1919; Logomarca da FAU/USP, Martino, 1961.....................................64

Figura 35 - Faculdade de Arquitetura e Urbanismo da Universidade de São Paulo, 1961, vista aérea. .................65

Figura 36 - Faculdade de Arquitetura e Urbanismo da Universidade de São Paulo, 1961, Salão Caramelo.........66

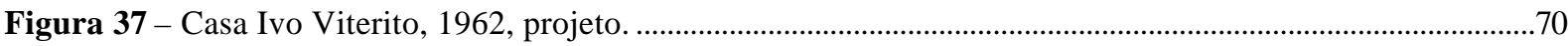

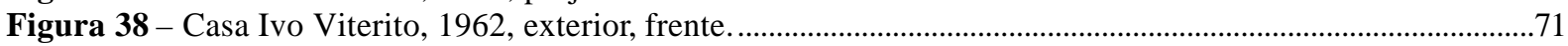

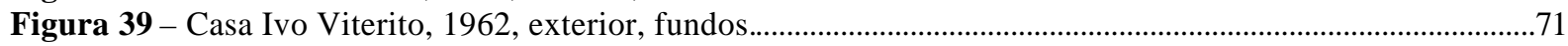

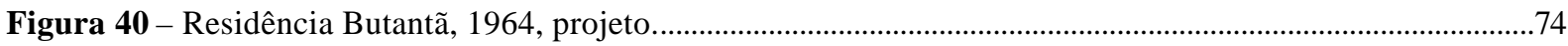

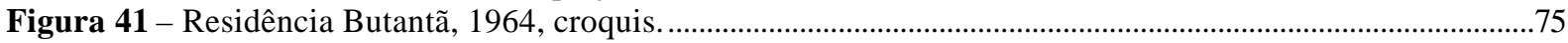

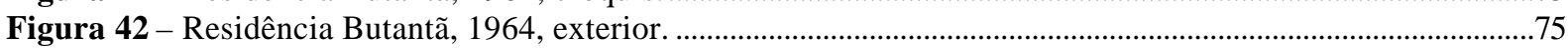

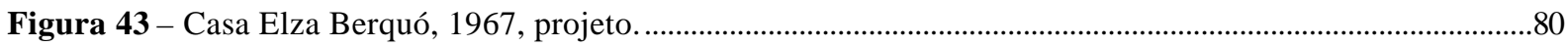

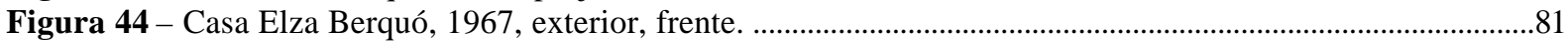

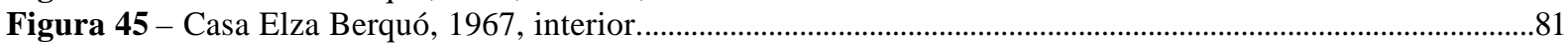

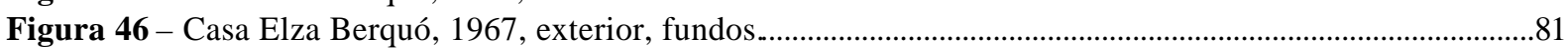

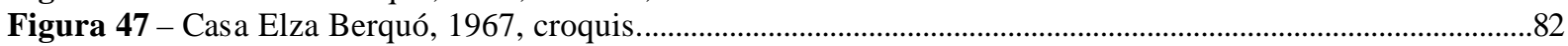

Figura 48 - Conjunto Zezinho Magalhães, 1967, projeto original com componentes industrializados.................84

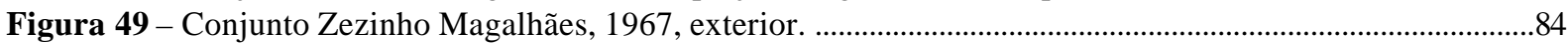

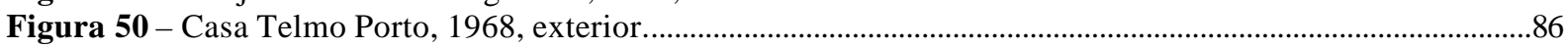

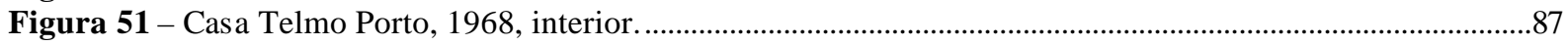

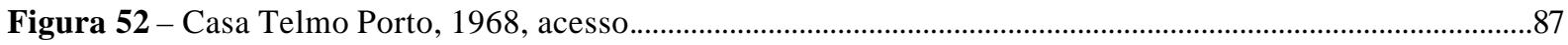

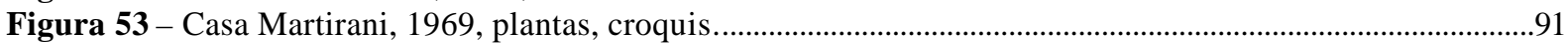

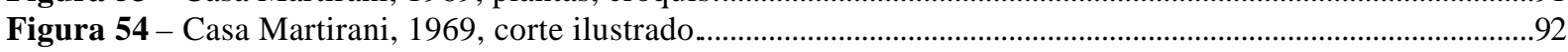

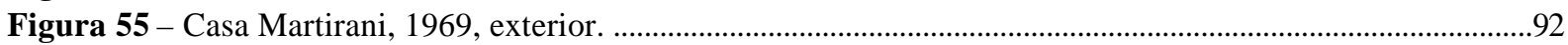

Figura 56 - Pavilhão do Brasil para a Expo' 70 de Osaka, 1969-70, plantas........................................................97

Figura 57 - Pavilhão do Brasil para a Expo' 70 de Osaka, 1969-70, cortes. ..........................................................98

Figura 58 - Pavilhão do Brasil para a Expo' 70 de Osaka, 1969-70, elevações........................................................98 
Figura 59 e 60 - Pavilhão do Brasil para a Expo' 70 de Osaka, 1969-70, maquete. ...............................................99

Figura 61 e 62 - Pavilhão do Brasil para a Expo' 70 de Osaka, 1969-70 ..............................................................99

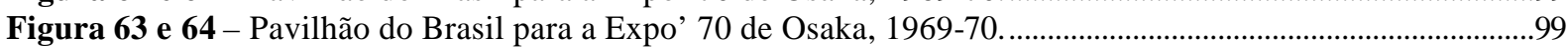

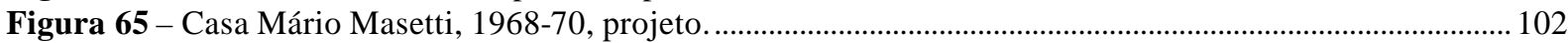

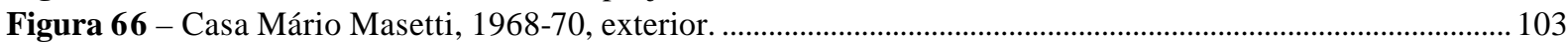

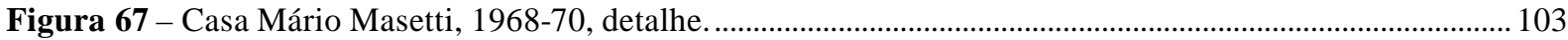

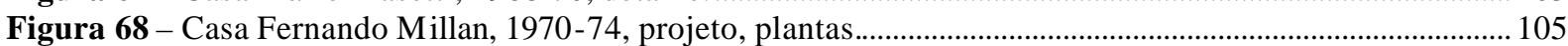

Figura 69 - Casa Fernando Millan, 1970-74, projeto, cobertura e corte.................................................................. 106

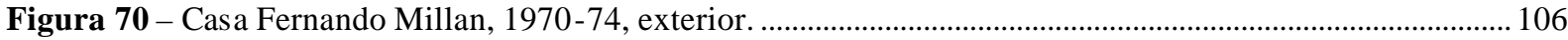

Figura 71 e 72 - Casa Fernando Millan, 1970-74, sala; cobertura....................................................................... 107

Figura 73 e 74 - Casa Fernando Millan, 1970-74, interior; exterior. ....................................................................... 107

Figura 75 e 76 - Casa James King, 1972-74, exterior e vegetação....................................................................... 108

Figura 77 e 78 - Casa James King, 1972-74, exterior e pátio.................................................................................. 108

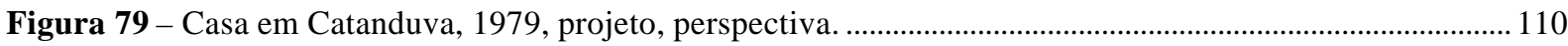

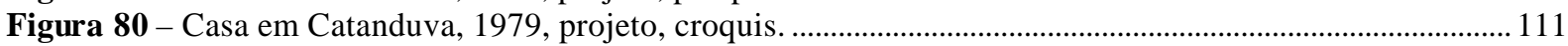

Figura 81 - Casa em Catanduva, 1979, projeto, croquis, unidade tripartida........................................................ 112

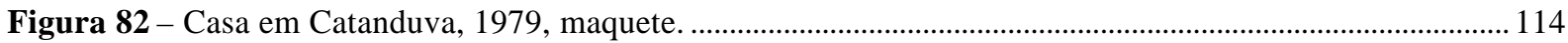

Figura 83 - Casa em Catanduva, 1984 (2 $2^{\circ}$. Projeto), vista do pátio interno.......................................................... 116

Figura 84 - Museu Brasileiro da Escultura, 1986-95, projeto (1) ...................................................................... 118

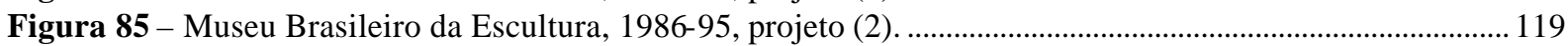

Figura 86 - Museu Brasileiro da Escultura, 1986-95, croquis............................................................................. 119

Figura 87, 88, 89 - Museu Brasileiro da Escultura, 1986-95, exterior................................................................... 120

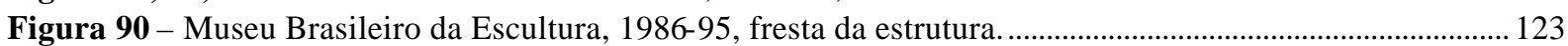

Figura 91 - Museu Brasileiro da Escultura, 1986-95, praça. ............................................................................ 123

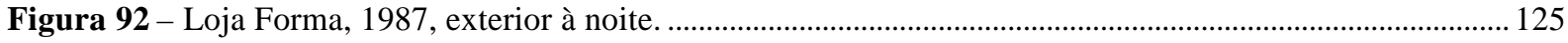

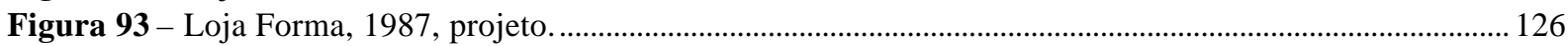

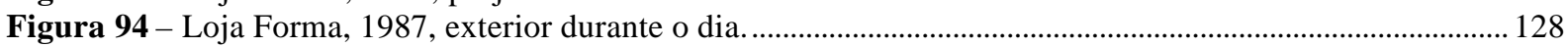

Figura 95 - Pavilhão do Brasil para a Expo' 92, em Sevilha, 1990-91, croquis, exterior. ....................................132

Figura 96 - Pavilhão do Brasil para a Expo' 92, em Sevilha, 1990-91, projeto (1)............................................ 132

Figura 97 - Pavilhão do Brasil para a Expo' 92, em Sevilha, 1990-91, projeto (2)............................................ 133

Figura 98 - Pavilhão do Brasil para a Expo' 92, em Sevilha, 1990-91, projeto (3)................................................. 134

Figura 99 - Pavilhão do Brasil para a Expo' 92, em Sevilha, 1990-91, maquete. .................................................. 138

Figura 100 - Pavilhão do Brasil para a Expo' 92, em Sevilha, 1990-91, maquete. .............................................. 140

Figura 101 - Pavilhão do Brasil para a Expo' 92, em Sevilha, 1990-91, maquete. .............................................. 140

Figura 102 - Pavilhão do Brasil para a Expo' 92, em Sevilha, 1990-91, croquis, interior.....................................143

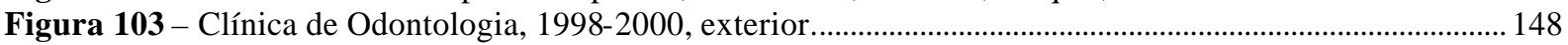

Figura 104 - Clínica de Odontologia, 1998-2000, edifício e entorno (1)...........................................................149

Figura 105 - Clínica de Odontologia, 1998-2000, edifício e entorno (2) . .............................................................. 149

Figura 106 - Clínica de Odontologia, 1998-2000, edifíc io e entorno (3). ................................................................ 149

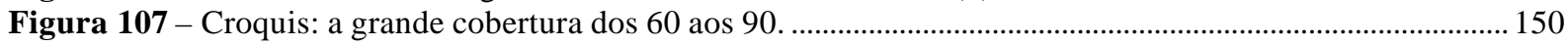

Figura 108 - Clínica de Odontologia, 1998-2000, projeto, planta nível $(-1,48)$................................................. 151

Figura 109 - Clínica de Odontologia, 1998-2000, projeto, planta nível $(+1,12)$................................................. 151

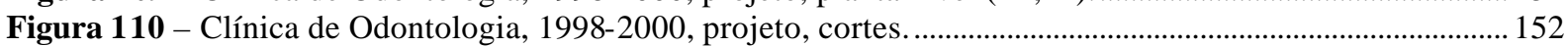

Figura 111 - Clínica de Odontologia, 1998-2000, projeto, corte D. ......................................................................... 153

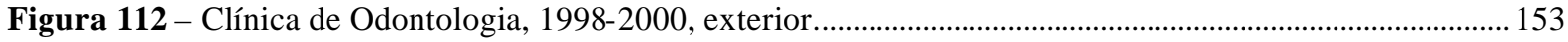

Figura 113 e 114 - Clínica de Odontologia, 1998-2000, recuos integrados............................................................... 155

Figura 115 e 116 - Clínica de Odontologia, 1998-2000, exterior, brises de madeira..............................................156

Figura 117 e 118 - Clínica de Odontologia, 1998-2000, interior, transparências................................................... 156

Figura 119 e 120 - Clínica de Odontologia, 1998-2000, estrutura, vértices de luz. ...........................................156

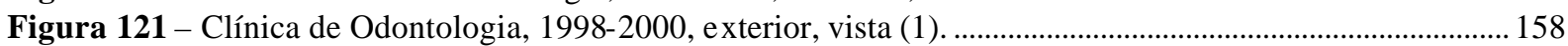

Figura 122 - Clínica de Odontologia, 1998-2000, exterior, vista (2) ................................................................... 158

Figura 123 - Clínica de Odontologia, 1998-2000, exterior à noite (foto de Nelson Kon).....................................162 


\section{LISTA DE SIGLAS}

$\mathrm{ABI}$

BIA

FAU/USP

$\mathrm{IAB}$

IPESP

MES

MuBE

$\mathrm{PC}$

SAM
Associação Brasileira de Imprensa

Bienal Internacional de Arquitetura

Faculdade de Arquitetura e Urbanismo da Universidade de São Paulo

Instituto de Arquitetos do Brasil

Instituto de Previdência do Estado de São Paulo

Ministério da Educação e Saúde

Museu Brasileiro da Escultura

Partido Comunista

Sociedade de Amigos dos Museus 


\section{SUMÁRIO}

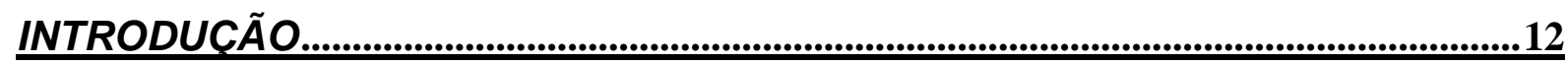

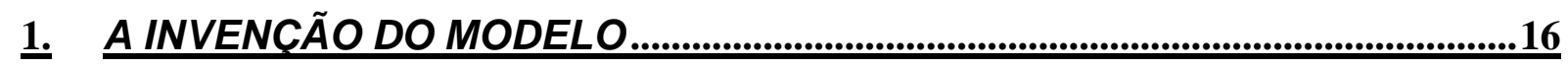

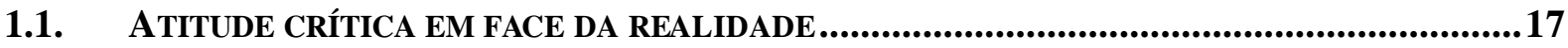

1.2. A POSTURA POLÍTICA NAOPÇÃO PELO CONCRETO ARMADO..........................................33

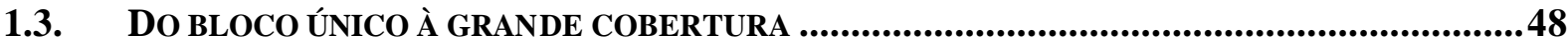

2. OENCASTELAMENTO ESTÉTICO E POLÍTICO DA ARQUITETURA............67

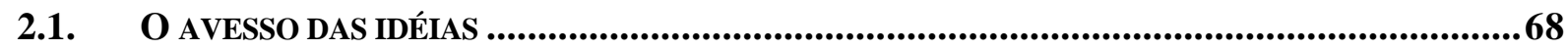

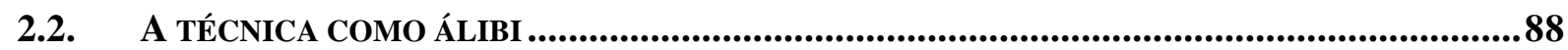

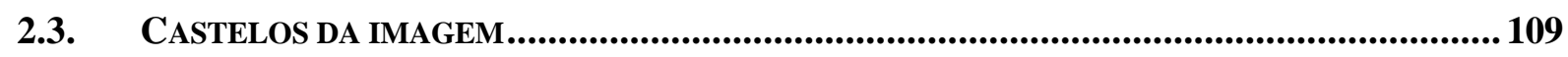

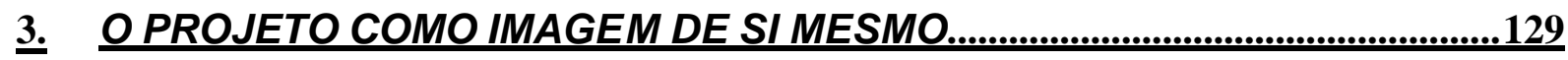

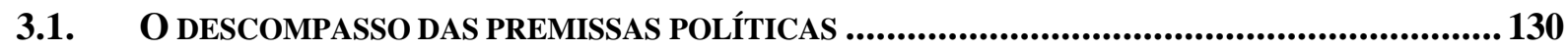

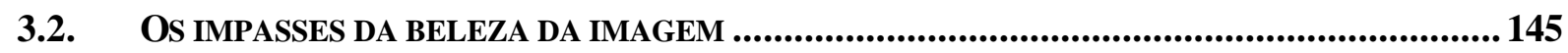

ALGUMAS CONSIDERACÕES SOBRE A MUDANCA DE SENTIDO DA

ARQUITETURA ........................................................................................................163

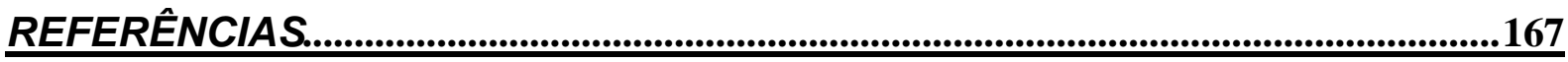




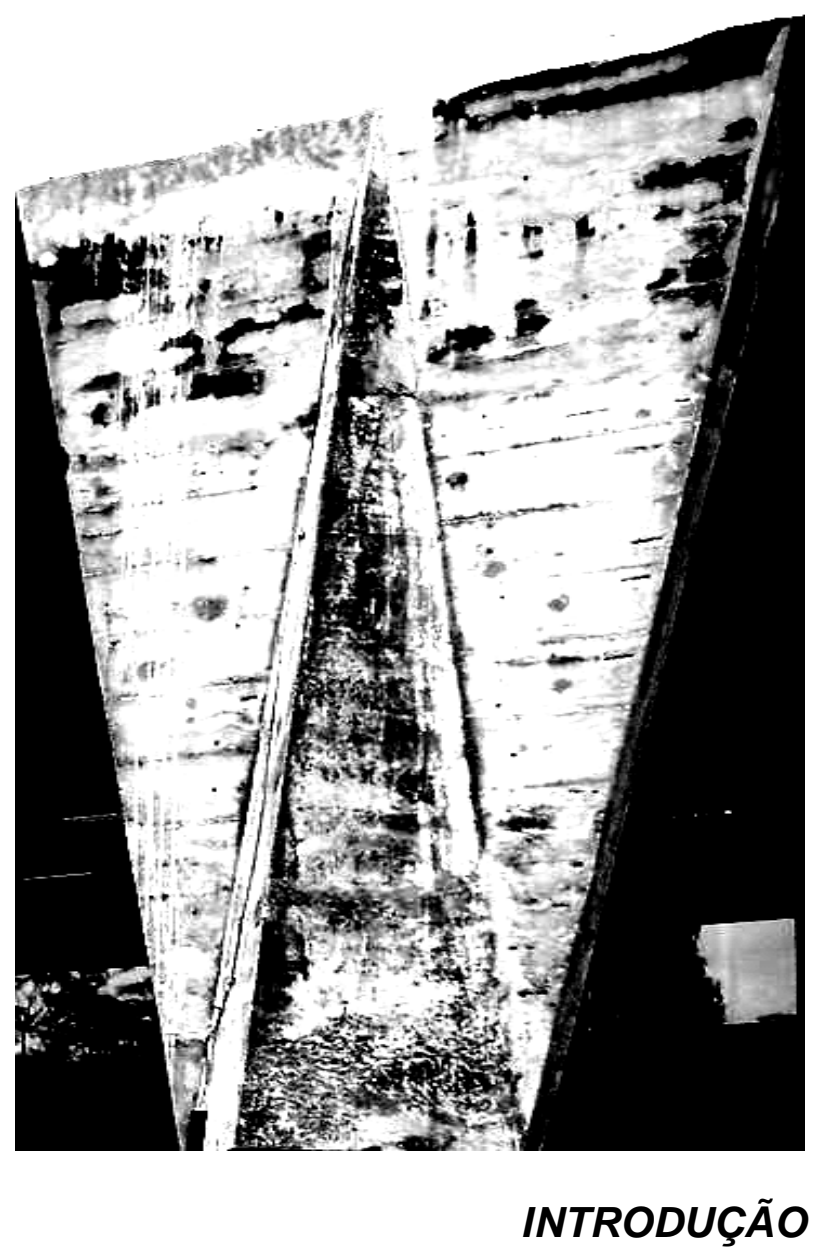


Durante a década de 1950, por meio do trabalho do arquiteto Vilanova Artigas, se verifica uma posição acurada diante da constituição da arquitetura moderna no Brasil. O que, até então, tinha como características, a liberdade formal e os valores plásticos de uma produção marcada pela criatividade de traços soltos, que se convencionou chamar de “arquitetura carioca", ganha contornos austeros, mediante a produção e reflexão política deste arquiteto.

A dura realidade desse período, num país marcado por contrastes, não impediu que Artigas nutrisse uma atitude crítica em face aos descalabros de uma cidade como São Paulo, em vias de industrialização, mas com a maioria de sua população carente de todo o tipo de infra-estrutura. Suas concepções arquitetônicas eram imbuídas de pressupostos sociais, técnicos e econômicos os quais, em sua visão, poderiam levar à democratização dos recursos da nação, contribuindo para a constituição de um projeto cultural que almejava uma reviravolta política.

Desse modo, as premissas políticas de Artigas foram responsáveis pela geração de uma arquitetura que tinha, como preconização, o enfrentamento das nossas contradições, ao mesmo tempo em que trazia, consigo, uma promessa coletiva que visava a melhoria de vida de toda a sociedade. Nesse caso, tanto a conformação espacial das suas casas - como bloco único introspectivo que se opunha ao entorno fragmentado, ambicionando sua reordenação -, bem como a concepção da grande cobertura - como espaço privilegiado de encontros, passível de ser constituído pela industrialização da construção - resultaram na invenção de um "modelo" que passou a ser chamado de "arquitetura paulista".

Até então, raríssimos foram os momentos da história da arquitetura brasileira em que o engajamento político crítico tivera tanto peso - indo além da própria concepção arquitetônica -, sendo decorrente da "tomada de consciência" dos graves problemas presentes no quadro 
econômico e social do país, num esforço de confrontá-los. Todavia, depois do golpe militar, diante de um "aprofundamento da decomposição estrut ural do país", a técnica permaneceu como justificativa da construção formal, enquanto se abrandou consideravelmente os embates no âmbito do projeto arquitetônico.

Nas últimas décadas, após os ideais socialistas terem se exaurido, a arquitetura produzida no país é cada vez mais pautada por imposições da mídia e do mercado, ao mesmo tempo em que os pressupostos políticos, outrora patentes, têm se escasseado. Dessa maneira, se em muitos casos da produção paulista contemporânea, a organização espacial e programática do projeto arquitetônico permanece intocada, por outro lado, sofre uma brusca redução das políticas em relação à arquitetura. Este problema transcende a disciplina, sobretudo, pelo agravamento da situação sócio-econômica do Brasil, durante os anos 90, no qual registroutse o arrefecimento das ações públicas.

Mediante essa problemática, entendemos que, em presença do desequilíbrio da sociedade brasileira e de uma posição desfavorável da nossa economia, dentre outras tantas deficiências reveladas pelas ambigüidades de um país construído às avessas, o "know-how" de um repertório - neste caso, aquele associado à chamada "arquitetura paulista" - não é capaz de uma incisiva transformação cultural sem que seja acompanhado de uma atitude crítica que possa dar lastro ao projeto arquitetônico. Nesses termos, defendemos a hipótese de que a "arquitetura paulista", na sua derivação recente, transformou o seu "modelo" em imagem de sim mesmo, porque esvaziado de conteúdo político crítico.

Nesta tese, assumimos como premissa o próprio princípio gerador da chamada "arquitetura paulista", qual seja, a conjunção entre reflexão espacial e reflexão crítico-política, resultando em uma concepção arquitetural coerente e significativa em ambos os sentidos. 
No exame da formação desse "modelo" em suas transformações, partimos, no primeiro capítulo, dos pressupostos políticos da obra do arquiteto Vilanova Artigas, nos anos 50 e 60, detendo-nos em algumas de suas construções, a fim de apontar suas afirmações e seus conflitos em relação ao papel da arquitetura diante da realidade díspar do país. Tem-se, como contraponto, a sua confiança na técnica do concreto armado para a constituição de um modelo que pudesse solucionar os problemas sociais por meio da arquitetura.

O trajeto sobre o desenrolar dessa produção perpassa, no segundo capítulo, por certos projetos específicos do arquiteto Paulo Mendes da Rocha, entendendo que alguns elementos presentes nesses trabalhos possam dar pistas para a compreensão do que chamamos de um encastelamento estético e político da arquitetura, na medida em que o discurso sócio-cultural das obras aqui selecionadas, realizadas a partir dos anos 70, passa a ser afirmado pela técnica como um álibi, em defesa de questões de ordem universal.

No terceiro capítulo, o trabalho vencedor do Pavilhão da Expo'92 em Sevilha atua como um elo de passagem para a consideração de certa produção mais recente, buscando-se configurar o caminho tomado pela "arquitetura paulista". Analisamos a maneira como se deu a apropriação de uma linguagem convalidada na década de 60, porém apresentando-se agora como imagem de si mesma.

Neste percurso, as transformações conceituais efetivadas em relação ao "modelo" inicial da chamada "arquitetura paulista" conformam um caso especial e significativo para pensarmos sobre a mudança de sentido da arquitetura nos dias de hoje. 


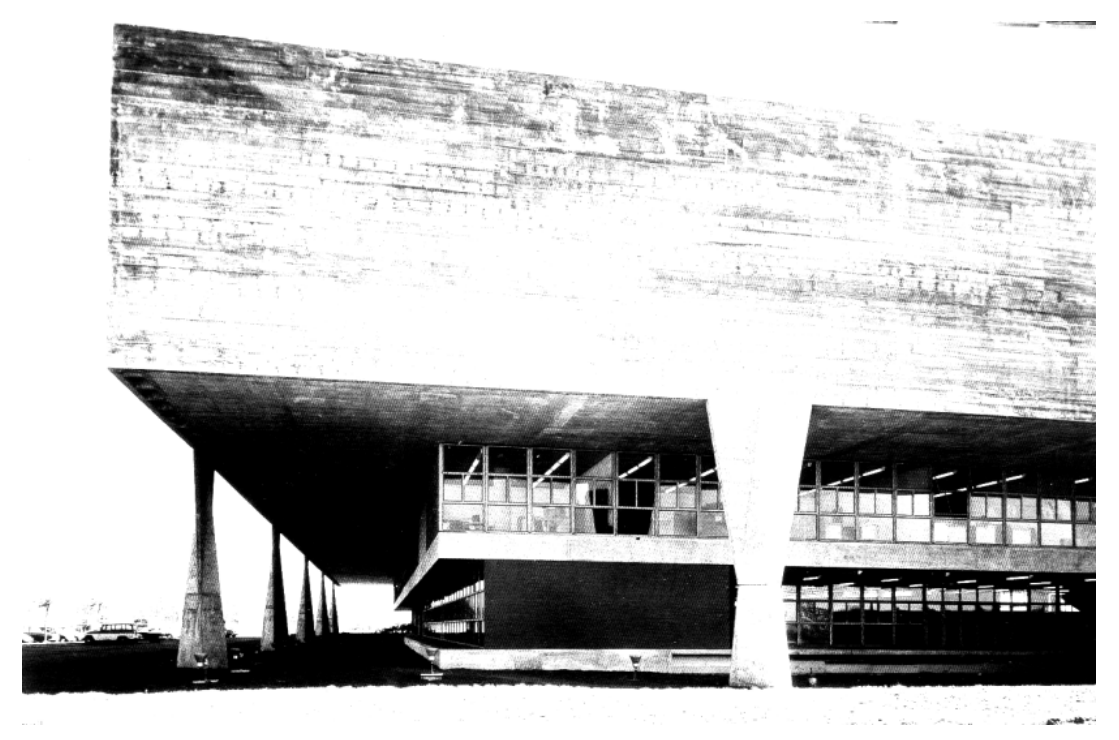

1. A INVENÇÃO DO MODELO 


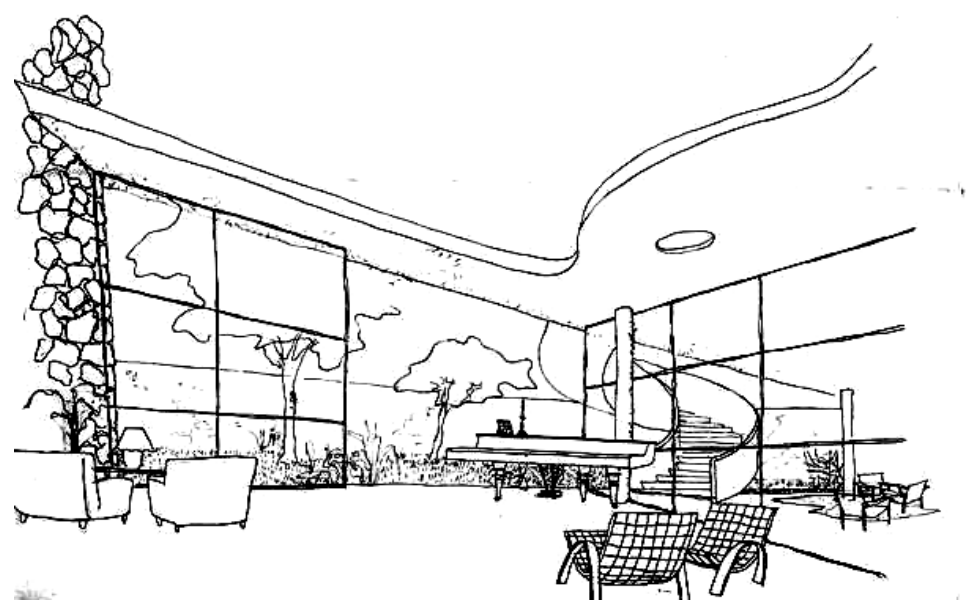

1.1. Atitude crítica em face da realidade 
O catálogo que leva o mesmo nome da mostra "Brazil Builds: Arquitetura Nova e Antiga, 1652-1942", de Philip Goodwin (1943), destaca o "caminho próprio" que os arquitetos cariocas deram à arquitetura moderna construída no Brasil. Os seus textos referendam, nas linhas mais marcantes desses edifícios, as soluções criativas ao adaptar o racionalismo modernista aos trópicos, tais como no Ministério da Educação e Saúde (193745), no Rio de Janeiro e nos prédios de Oscar Niemeyer, pela liberdade formal e franca abertura da edificação para a paisagem. ${ }^{1}$

Uma produção, cujos valores plásticos alimentam o intento de constituição de uma “identidade” proposta pelo Estado Varguista (de cunho autoritário), empenhado na construção ideológica da nacionalidade. Desta maneira, a busca por uma originalidade e pela criação de uma linguagem autenticamente brasileira se deu pela incorporação, de modo livre e particular, dos pressupostos da ortodoxia funcionalista, caracterizando o que se convencionou chamar de "arquitetura carioca". Esta seria reconhecida, em âmbito internacional, por meio da imagem de algumas obras emblemáticas construídas em um país periférico e, por isso, tratadas como “revelação". ${ }^{2}$

A casa Antônio L. T. de Barros (1946), construída em São Paulo pelo arquiteto Vilanova Artigas, revela traços característicos dessa arquitetura até então produzida no país, pois a sinuosa marquise de concreto armado que demarca a entrada da residência possibilita certa liberdade formal. Todavia, outras recorrências podem ser lidas, seja nas transparências

\footnotetext{
${ }^{1}$ GOODWIN, P. L. Brazil Builds: Arquitetura Nova e Antiga, 1652-1942. Nova York, The Museum of Modern Art, 1943, p. 94.

${ }^{2}$ COSTA, L. Relato Pessoal. In: COSTA, L. Lúcio Costa: registro de uma vivência. São Paulo, Empresa das Artes, 1995, p. 137. (artigo originalmente publicado em: Módulo, Rio de Janeiro, n. 40, 1975). O Ministério da Educação e Saúde - MES (1937-45), no Rio de Janeiro, de Lúcio Costa, Affonso Eduardo Reidy, Carlos Leão, Ernani Vasconcelos, Jorge Machado Moreira e Oscar Niemeyer, a Associação Brasileira de Imprensa - ABI (1936-38), no Rio de Janeiro, dos irmãos MM Roberto, o conjunto de edifícios em torno da lagoa da Pampulha (1942-43), em Belo Horizonte, de Oscar Niemeyer e os Edifícios do Parque Guinle (1948-54), no Rio de Janeiro, de Lúcio Costa, podem ser alguns desses exemplos. Como descreve Costa (1975), a arquitetura brasileira tornouse parada obrigatória para os arquitetos do exterior, que vinham até o Brasil exclusivamente, "[...] para conhecer o Ministério, a ABI, a Pampulha, o Parque Guinle [...]”.
} 
que buscam uma integração entre o interior-exterior ou na cobertura em tesoura invertida uma particular apropriação da laje plana que rememora a obra de Oscar Niemeyer.
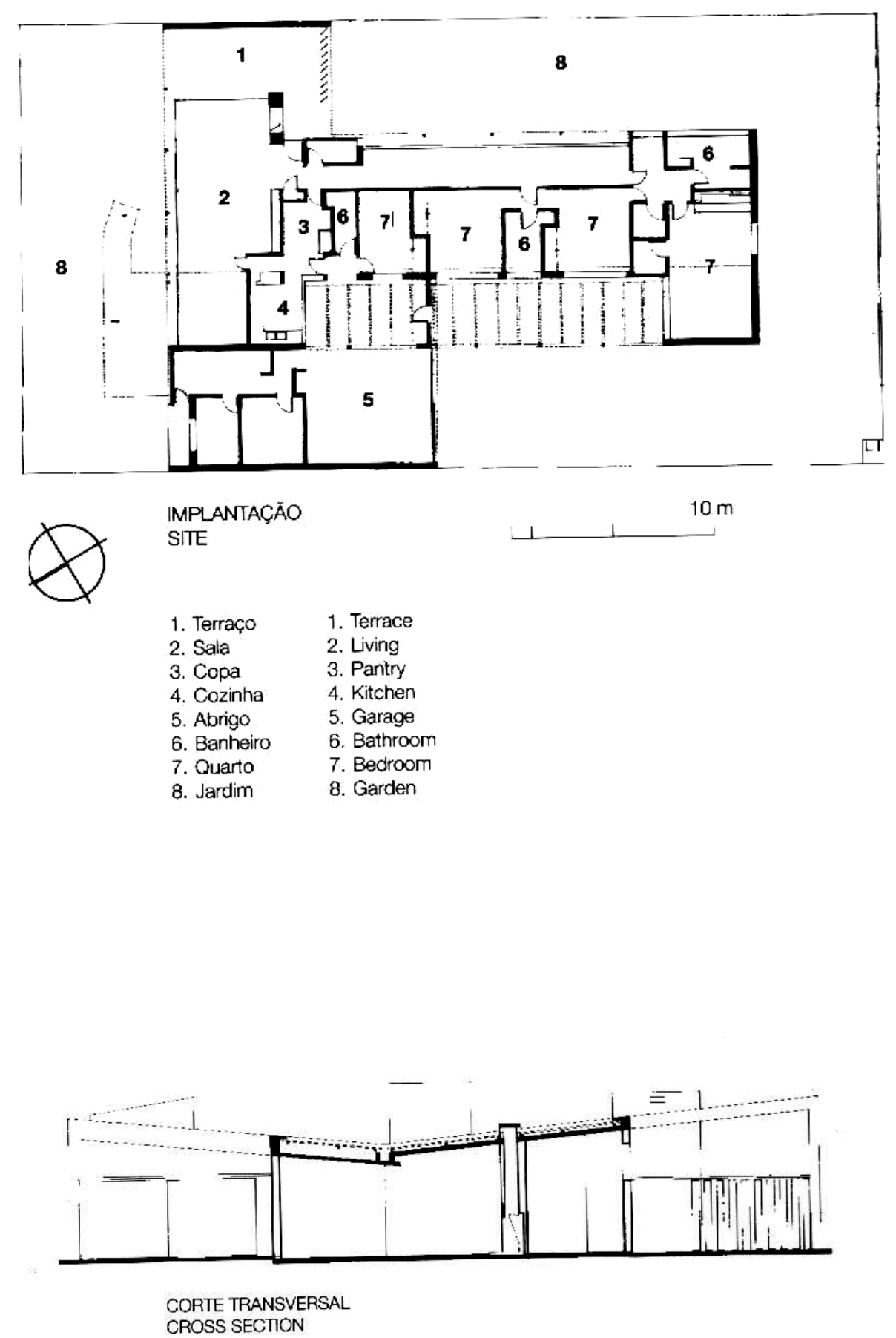

Figura 01 - Casa Antônio L. T. Barros, 1946, projeto. Fonte: Artigas (1997, p. 54). 


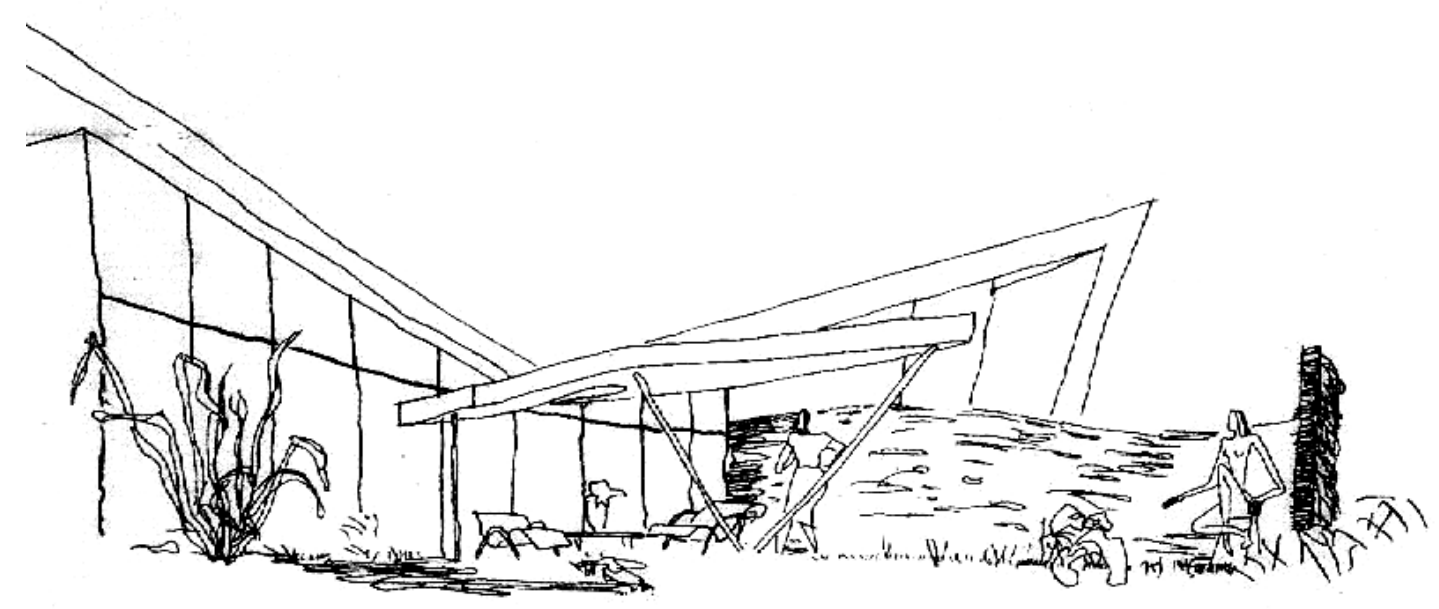

Figura 02 - Casa Antônio L. T. Barros, 1946, croquis. Fonte: Artigas (1997, p. 53).

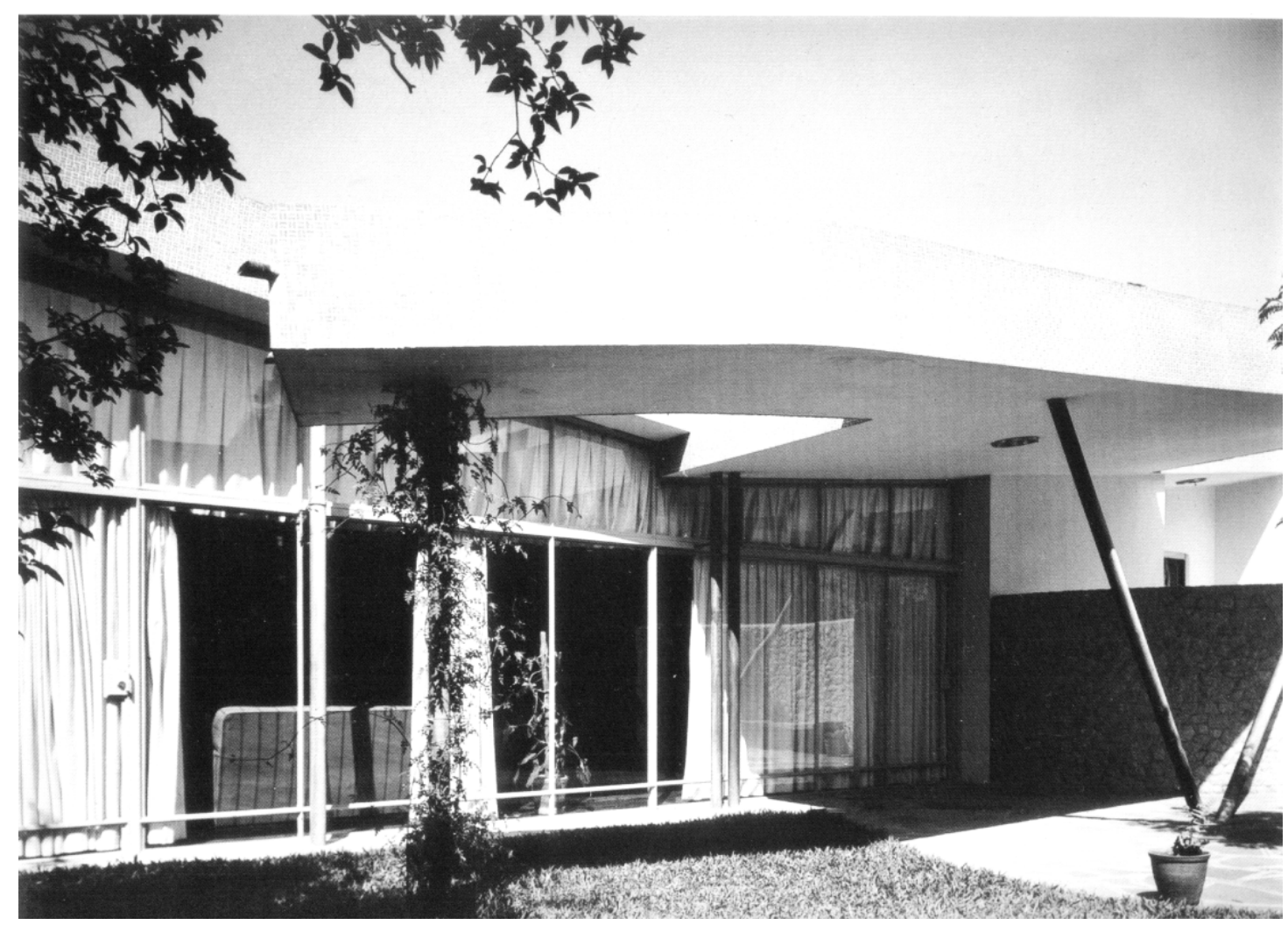

Figura 03 - Casa Antônio L. T. Barros, 1946, exterior. Fonte: Artigas (1997, p. 54). 
Entretanto, durante a segunda metade dos anos 40, a conformação urbana de São Paulo revelava uma acelerada especulação fundiária, cujo resultado foi a saturação das áreas centrais e a ocupação quase que total do solo urbano. Isto viria a dificultar uma franca apropriação dessas formas e a promoção das generosas implantações semelhantes àquelas que caracterizavam os edifícios modernos cariocas que tinham, como pano de fundo, uma paisagem natural. ${ }^{3}$ Também porque, na capital paulista, o Estado não era um importante agente promotor da arquitetura, impedindo, em grande medida, a constituição de um continuum entre "linguagem arquitetônica" e "proposições urbanísticas". 4

Nesse contexto, o edifício Louveira (1946), projetado em São Paulo pelos arquitetos Vilanova Artigas e Carlos Cascaldi, se transforma num exemplo para alguns arquitetos paulistas, pelo “[...] tipo de aproveitamento do terreno e de forma do edifício [...]". ${ }^{5}$ Nesse conjunto, dois prédios de apartamentos são ajustados nos extremos do lote urbano para conseguir um vazio central ambientado por vegetação, como extensão da área arborizada defronte ao terreno. Essa clareira urbana contínua é pontuada por duas rampas curvas de concreto armado que convidam à entrada no espaço não construído, como num balé em sobrevôo. Essa transição confere fluidez ao complexo edificado, além de configurar o acesso aos blocos diretamente em contato com a Praça Vilaboim.

\footnotetext{
${ }^{3}$ Vale lembrar que o Rio de Janeiro era então a capital administrativa do país e dispunha, na área central, de amplos terrenos vagos, os quais foram decorrentes dos desmanches dos morros do Castelo e do Santo Antônio, onde foram construídos alguns edifícios tais como: o MES, a ABI, a Estação de Hidroaviões (1937-38), de Atílio Correia Lima, o Aeroporto Santos Dumont (1937-44), dos irmãos Roberto, o Parque do Flamengo (1953-62) e o Museu de Arte Moderna do Rio de Janeiro (1953-68), de Affonso Eduardo Reidy, além de inúmeros outros projetos.

4 MARTINS, C. A. F. Construir uma Arquitetura, Construir um País. In: SHWARTZ, J. (Org.). Da Antropofagia a Brasília: Brasil 1920-1950. São Paulo, FAAP/ Cosac Naify, 2002, p. 378. Para esse autor, a continuidade entre espaço arquitetônico e urbano era comum à arquitetura moderna carioca, sobretudo, pela influência de Le Corbusier na constituição do MES. Os croquis que antecederam a proposta definitiva elaborada pelos arquitetos brasileiros, revelam a preocupação de Le Corbusier em abarcar, por meio da amplitude do pano de vidro do edifício, as visuais exuberantes da paisagem do Rio de Janeiro. Esta concepção logo depois irá se traduzir em uma pretensa continuidade espacial na cortina de vidro e no grande vão livre do prédio do MES, na busca por integrar a obra, o lote e a quadra.

5 ARTIGAS, V. Vilanova Artigas: arquitetos brasileiros. São Paulo, Instituto Lina Bo e P. M. Bardi / Fundação Vilanova Artigas, 1997, p. 55.
} 

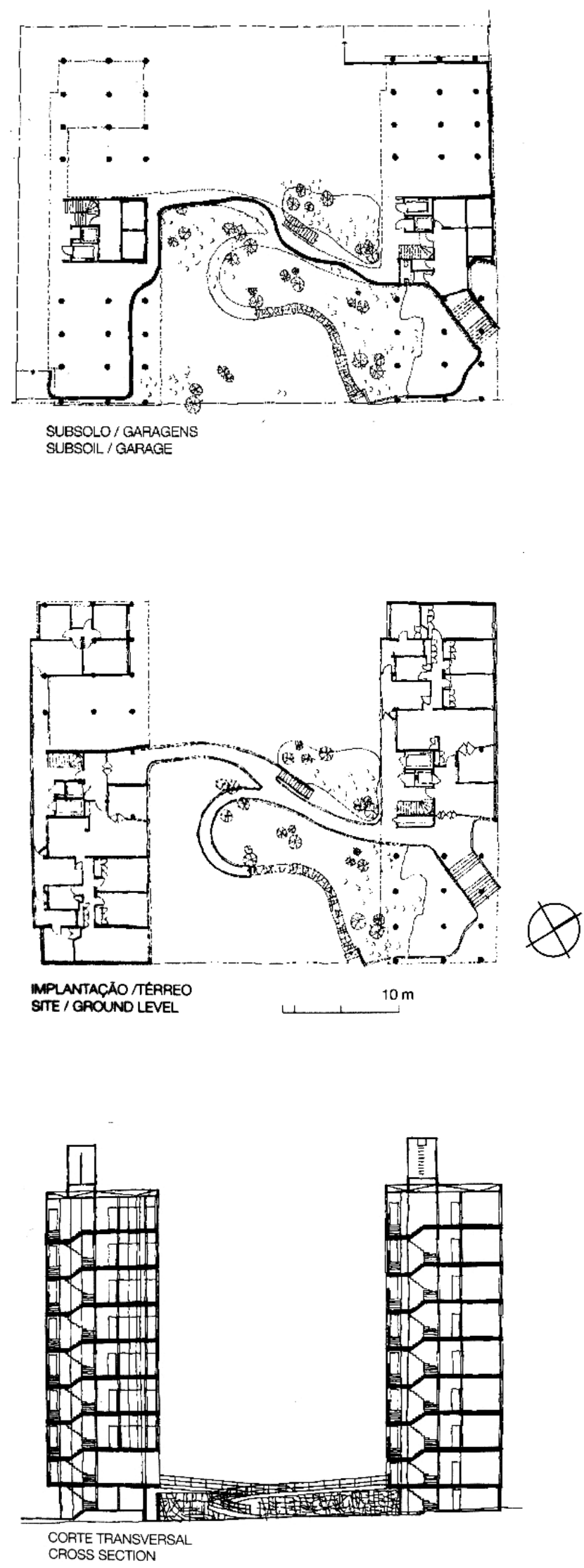

Figura 04 - Edifício Louveira, 1946, projeto. Fonte: Artigas (1997, p. 56). 


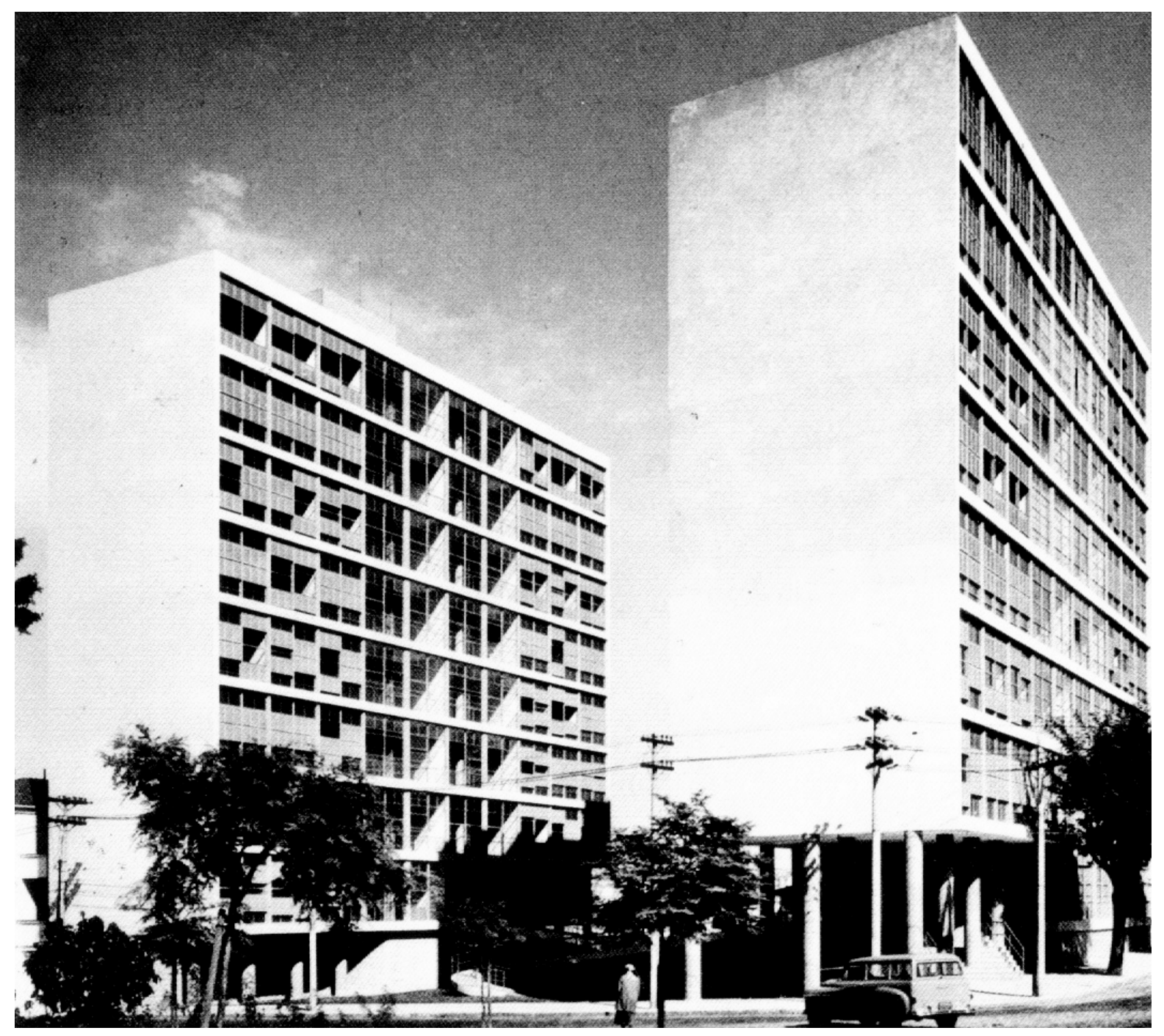

Figura 05 - Edifício Louveira, 1946, exterior. Fonte: Artigas (1997, p. 56).
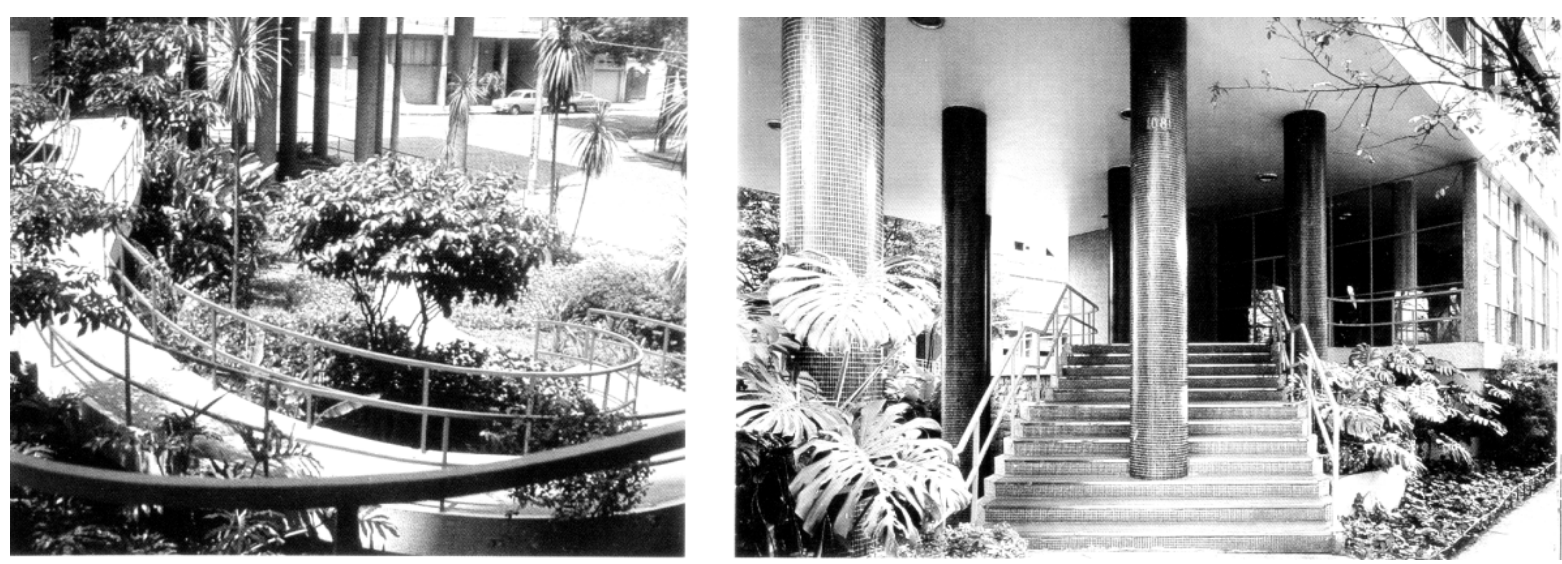

Figura 06 e 07 - Edifício Louveira, 1946, detalhe. Fonte: Artigas (1997, p. 57). 
Uma edificação que serviu de base para a construção de vários outros prédios na capital paulista, pois, em relação ao tipo de arquitetura produzida na época, configurou avanços do ponto de vista estrutural e programático. Além disso, vislumbrou possibilidades de interconexão com seu entorno imediato, apesar de deixar expostos os impasses dessa ação. Isto porque, o hiato entre as empenas cegas se constituiu apenas como uma estreita faixa - o quinhão que pôde restar do espaço privado, em um horizonte que perderia o seu ponto de fuga, pela rapidez com que se processaria o adensamento vertical na cidade. ${ }^{6}$

Sob a ótica da diferenciação entre a amplitude da paisagem do Rio de Janeiro e o panorama urbano da capital paulista condensado pela verticalização, o edifício Louveira poderia ser compreendido como uma obra contraditória, pois está circunscrito ao típico programa destinado a um condomínio residencial de alto padrão, enquanto tenta driblar a lógica da propriedade da terra, ao constituir uma espécie de pátio semi-público, sob o desejo de incorporar o edifício à cidade - talvez, como um espólio da lição carioca. ${ }^{7}$

A $2^{\text {a }}$. casa de Artigas (1949) revela o nó de tentar formular uma concepção que corroborasse para assegurar a continuidade espacial entre arquitetura e urbanismo. Um exemplar racionalista, todo envidraçado, rememorando uma habitação corbusieriana que busca construir uma ligação entre interior-exterior, mesmo não podendo existir uma relação com o seu entorno. Ao tentar abarcar as visuais de uma paisagem entrecortada pelo domínio particular, o desejo de uma amplitude espacial se circunscreve ao perímetro do próprio lote. ${ }^{8}$

\footnotetext{
${ }^{6}$ Durante as décadas de 1940 e 1950, acentua-se o processo de verticalização no centro da cidade de São Paulo. No entanto, esse fenômeno não está circunscrito apenas às áreas mais valorizadas, porque nesse período, o adensamento vertical também vai se "espraiando" para regiões menos valorizadas. Cf. SOMEKH, N. A (des) verticalização de São Paulo. São Paulo, dissertação de mestrado apresentada à FAU-USP, 1987, p. 84.

7 “[...] Nos anos 50 a cidade de São Paulo surge como força urbano-industrial, o que exige uma outra formulação arquitetônica em relação à síntese ligada ao Estado nacional e à capital federal [...]”. Cf. RECAMÁN, L. Curvas e Retas não alcançam as cidades no Brasil. Vitruvius. Disponível em:

<http://www.vitruvius.com.br/arquitextos/arq000/esp394.asp>. 2006. Acesso em: 25 abr. 2008, p. 02.

${ }^{8}$ Esse projeto foi construído para ser uma casa de fim de semana, ao lado da casinha (1942), de Artigas - projeto de influência organicista, com telhado em águas, tal como os ensinamentos wrightianos.
} 

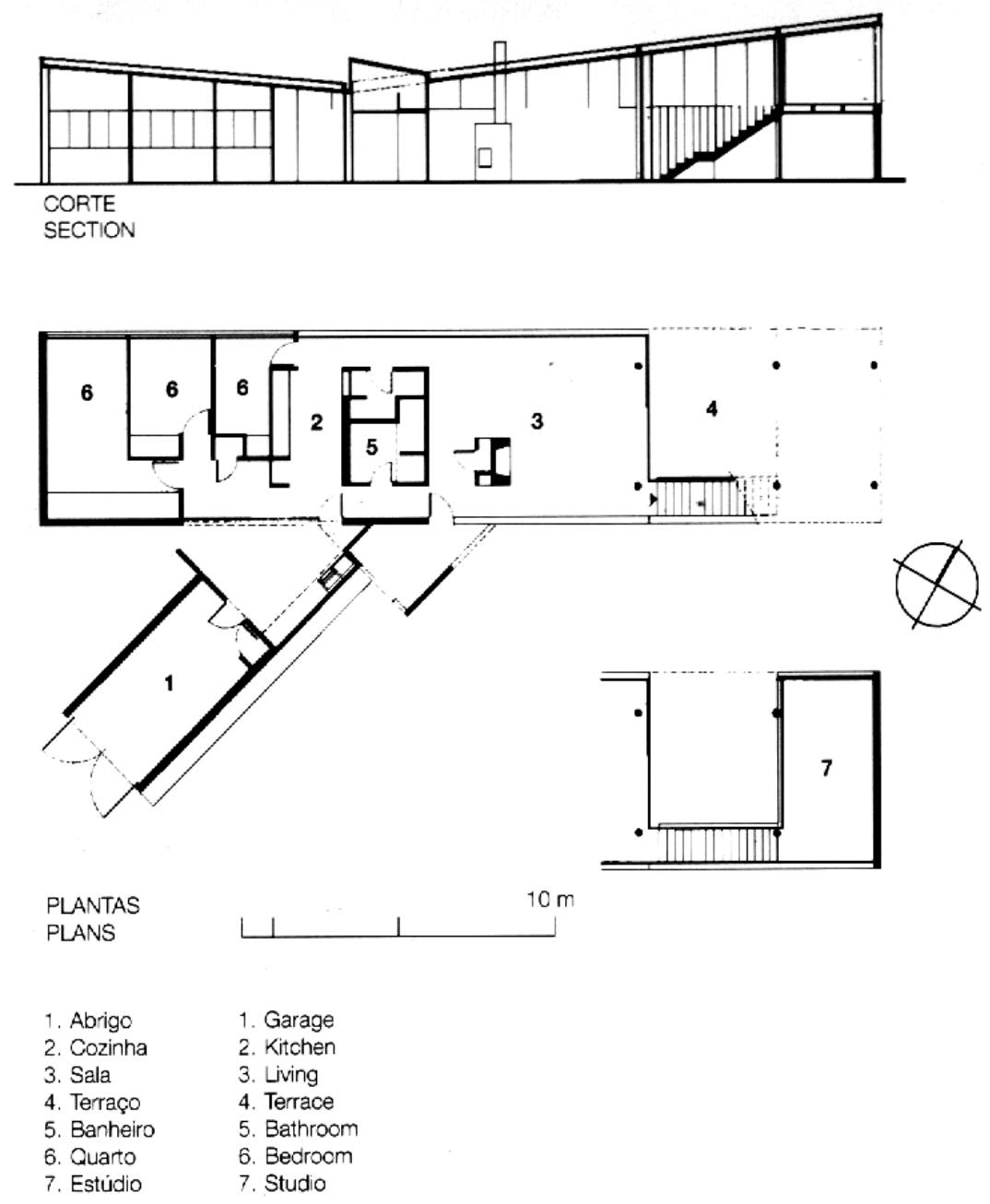

Figura 08 $-2^{\text {a }}$. Casa do Arquiteto, 1949, projeto. Fonte: Artigas (1997, p. 62).

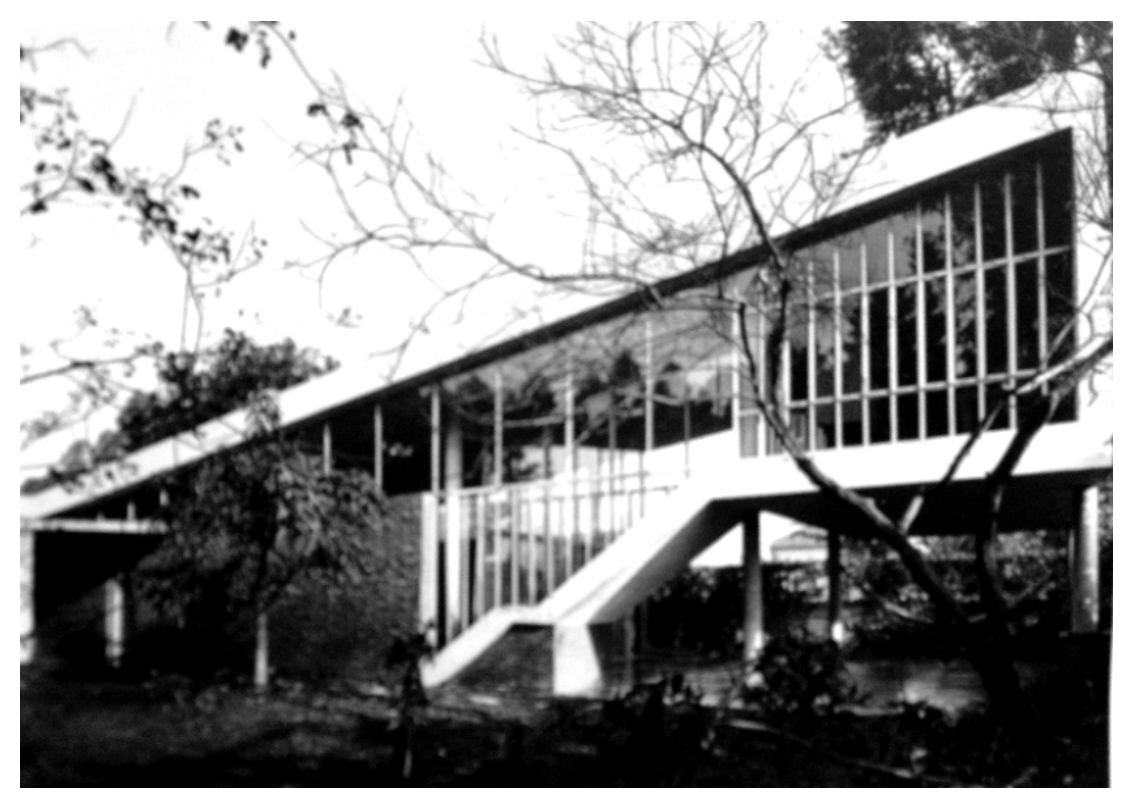

Figura 09-2 $2^{\mathrm{a}}$. Casa do Arquiteto, 1949, exterior. Fonte: Artigas (1997, p. 62). 
Por esse motivo, a percepção de que a exteriorização da arquitetura contradizia uma cidade que cada vez mais se interiorizava, pelos limites do parcelamento do solo urbano, não tardou a aparecer. Na visão de Artigas, a São Paulo do final dos anos 40 revelava a incongruência de se projetar num lugar onde a possibilidade de constituição dos espaços coletivos esbarrava nas empreitadas da "ganância imobiliária". Idéias que irão se acirrar quando Artigas se envolve "mais assiduamente" com as ações políticas do Partido Comunista - PC, a “[...] começar pelo seu ingresso no conselho de redação da revista Fundamentos, no princípio um periódico dedicado à cultura brasileira, mas logo dominado pelo grupo ligado ao partido". 9

No início dos anos 50, nas páginas desse periódico, Artigas então se volta contra o vocabulário dos "líderes do movimento modernista", sobretudo Le Corbusier, acreditando que o ideário que acompanhara a sua produção sempre privilegiara a ordem burguesa. Assim, sua postura passa a cobrar, dos profissionais brasileiros, uma "ideologia de reação" que pudesse levar em conta os avanços técnicos que foram conseguidos pela nossa produção arquitetônica, sem se submeter ao que chama de um "formalismo servil". 10

Diante do desconforto de perceber que, até meados da década de 50, os ideais socialistas, supostamente alcançáveis pelo racionalismo arquitetônico, ainda não haviam sido consumados, Artigas busca um realinhamento dos pressupostos modernos, de modo que estes

\footnotetext{
${ }^{9}$ KAMITA, J. M. Vilanova Artigas. São Paulo, Cosac Naify, 2000, p. 122. Depois da fundação do Instituto de Arquitetos do Brasil - IAB (1944), Artigas tem uma importante participação política no cenário paulista e também nacional. Em 1945 colabora na realização do $1^{\circ}$. Congresso Brasileiro de Arquitetos, organizado pelo IAB. Nesse mesmo ano filia -se com a esposa ao PC. De acordo com Kamita (2000), "[...] por meio do grupo Santa Helena, o casal passa a se relacionar com artistas e intelectuais de esquerda, interessados na experiência do socialismo soviético como fonte nspiradora na luta contra o Estado Novo." Em 1948 Artigas projeta as instalações do Museu de Arte Moderna de São Paulo, no centro da cidade, e colabora na fundação da Faculdade de Arquitetura e Urbanismo da Universidade de São Paulo - FAU/USP, no prédio da Rua Maranhão.

${ }^{10}$ Neste momento, para Artigas, os líderes do movimento modernista sempre mantiveram uma ligação com as classes dominantes. Assim, ao contrário de antes, Artigas incita o repúdio aos ideais de Le Corbusier - o que chegará a beirar certo extremismo -, por acreditar que seu livro "O Modulor" contém idéias que são contra o povo e a serviço do imperialismo americano. Cf. ARTIGAS, V. Le Corbusier e o imperialismo. In: ARTIGAS, V. Caminhos da Arquitetura. São Paulo, Cosac Naify, 2004, p. 28. (artigo originalmente publicado em: Fundamentos, Revista de Cultura Moderna, São Paulo, ano 3, n. 18, maio 1951, p. 8-9, 27).
} 
não se reduzam somente ao aspecto formal da produção arquitetônica, em uma cidade construída de maneira não igualitária, mas que possam se traduzir como luta pela melhoria de vida do homem oprimido, contra os ditames do international style e, principalmente, contra a vinculação do desenvolvimento da nação em associação aos interesses estrangeiros.

Vale ressaltar que durante o mandato de Vargas desses anos, a atração de capital externo alicerçava a indústria e a conseqüente modernização do país. No entanto, essa situação era contestada pelas premissas dos comunistas, na medida em que muitos partidários contavam com a superação do país agrário por meio de uma industrialização financiada pela nação, pois, nesse caso, o proletariado poderia ter o domínio sobre os meios de produção, promovendo a revolução operária e, então, "pular etapas", passando do capitalismo ao socialismo.

Porém, de acordo com essa noção "etapista" desenvolvimentista, primeiro, havia a necessidade de se ind ustrializar para, depois, estender as suas benesses. Isto não deixava de ser um contra-senso, pois a possibilidade de emancipação social não se faria apenas com a ruptura da dependência internacional, mas, também, com o próprio projeto de desenvolvimentismo - que via na implantação da indústria, a possibilidade de construir um Brasil pujante, mesmo sem as bases para tanto. Assim, segundo Schwarz (1970), de forma controvertida, os ideais reformistas do PC se ligavam aos interesses da burguesia industrial, nacional e progressista, para então combater os latifundiários, pró-americanos e retrógrados. ${ }^{11}$

Nesse sentido, essas idéias inflamadas que circulavam no partido irão, a partir de 1951, alimentar a discurso político de Artigas, deflagrando o seu profundo sentimento antiimperialista, avesso a qualquer interferência externa em nossa cultura e a favor de um projeto de progresso econômico e social dado pelo incremento da indústria. A sua ação irá

\footnotetext{
${ }^{11}$ SCHWARZ, R. Cultura e Política, 1964-1969. In: SCHWARZ, R. Cultura e Política. São Paulo, Paz e Terra, 2001, p. 12. (texto originalmente publicado em francês, em 1970).
} 
emergir da propositura de que, eliminando-se a influência norte-americana, o país poderia alcançar soberania e, consequentemente, por meio de um desenvolvimento endógeno, seria possível alterar a sua estrutura de classes.

Artigas (1951b) sustenta a idéia de que, para uma possível transformação das relações sociais do país, seria preciso que os artistas, em geral, se colocassem diante de um propósito ético, em favor dos reais problemas do povo. Talvez aí estivesse a veia de ligação com os antigos ideais revolucionários das vanguardas que ainda se acreditavam possíveis - a arte como forma de politização. Essa força de mobilização deveria lutar com os meios que lhe fossem peculiares, contra o imperialismo americano, mas, também, contra as condições precárias nas quais vivia a população. ${ }^{12}$

De acordo com o pensamento de Artigas, esse era o dilema a ser desfeito para se chegar a uma sociedade mais justa, na qual a produção arquitetônica não fosse a "arma de opressão da classe dominante”. Assim, nesse momento, seu trabalho como arquiteto estará envolvido mais com a militância que propriamente com a construção de obras - exceto pelo Estádio do Morumbi (1952).

Nesses anos, o tom do discurso de Artigas envereda para a busca de "uma nova teoria para a arquitetura moderna" que pudesse trazer ganhos para a sociedade como um todo. Partindo desse propósito, Artigas (1952) denuncia as promessas que não foram cumpridas pela arquitetura funcionalista e também revela o despropósito de se ordenar cidades que refletem a construção dos ideais burgueses, antes de atender às melhorias da coletividade. Nesse sentido, o arquiteto demarcará alguns dos principais problemas da urbanização

\footnotetext{
12 ARTIGAS, V. A Bienal é contra os artistas brasileiros. In: ARTIGAS, V. Caminhos da Arquitetura. São Paulo, Cosac Naify, 2004, p. 34. (artigo originalmente publicado em: Fundamentos, Revista de Cultura Moderna, São Paulo, ano 4, n. 23, dez. 1951, p. 10-12).
} 
brasileira, sobretudo, os da cidade de São Paulo, expondo a sua "agonia de viver dentro do caos urbano". (Artigas, 1952).

Essa expressão não trata apenas da verificação da ineficiência das planificações para conter o avanço da miséria urbana, em decorrência do crescimento desordenado da cidade, mas da desconfiança de que os planos não mais podiam resolver os problemas oriundos da mudança econômico-produtiva do país, sobretudo, aqueles realizados pelos norte-americanos, sobre quem recaia o repúdio imperialista - como no caso de Robert Moses que elaborava um planejamento para a capital paulista. Assim, o "caos urbano", sublinhado por Artigas, diz respeito à sua amargura diante da manutenção da matriz fundamental do sistema capitalista, a qual ele denomina: "a exploração do homem pelo homem" e não somente à desordem propriamente dita. (Artigas, 1952).

Nesse sentido, Artigas (1952) buscará revelar as contradições de um país que, mesmo sem dispor dos "mais elementares serviços públicos", se apresenta, por meio da chamada "arquitetura carioca", aclamada pelo mundo afora, como moderna e progressista. Desta maneira, o arquiteto faz um reexame da arquitetura produzida no Brasil, tentando então desmistificá-la, por considerá-la uma "demagogia desenfreada". Para ele, esta produção se produzia alijada dos princípios coletivos e a favor da "dominação ianque". Apesar do programa variado do intento da modernização, as mazelas continuavam "pululando" no Brasil.

No bojo das considerações de Artigas, a arquitetura moderna brasileira já havia se tornado parte do nexo do capital, em uma desvirtuação que concorria para um reforço da "penetração do imperialismo". Além disso, o modo como era propagandeada pela mídia internacional, que a colocou "ombro a ombro" com a realidade de outros países do globo, mascarava a possibilidade de um juízo acurado sobre o seu caráter produtivo, acalentando 
descompassos que, por vezes, favoreciam a simples assimilação estilística pelos jovens arquitetos do país. ${ }^{13}$

Sob esse ângulo, Artigas advogará por uma saída que não será nem estática à espera de uma nova sociedade, que para ele se caracterizava pela postura dos arquitetos cariocas, nem a do completo abandono da tarefa do arquiteto rumo a um engajamento revolucionário. Sua posição buscará expurgar as ilusões da arquitetura que se apresentavam até então, tomando partido da situação para que, ao mesmo tempo, se pudesse lutar pelo progresso do país e, aos poucos, selecionar as formas que levariam a uma emancipação nacional.

Nessa proposição, é evidente a vontade de reintegração de uma causa ao projeto arquitetônico que pudesse ir de encontro às necessidades do povo, mesmo porque, nas palavras do próprio Artigas (1952), apenas fazendo parte dele seria possível formular o "espírito crítico" capaz de criar uma "espontaneidade nova”, como uma "interpretação direta dos verdadeiros anseios populares".

No entanto, há também uma consciência de que essa ligação com a massa não poderia ser prontamente estabelecida, porque subentendia a superação de uma série de empecilhos, já que nenhuma transformação efetiva havia acontecido, enquanto o desenvolvimento, implementado pelo governo Vargas (1951-1954), só agravava os disparates sociais. Essa

\footnotetext{
13 A crítica estrangeira, amparada pela criteriosa distribuição do catálogo "Brazil Builds: Arquitetura Nova e Antiga, 1652-1942", de Philip Goodwin (1943) - que fora levado para "os mais afastados rincões do planeta", com a ajuda do Departamento de Estado norte-americano -, é o instrumento que vai postular os traços emblemáticos da produção arquitetônica nacional durante a ditadura do presidente Getúlio Vargas. Os dispositivos de controle da insolação dos edifícios brasileiros, além da desenvoltura plástica da arquitetura de Oscar Niemeyer referendavam as características marcantes dessa produção. Serão essas questões que passarão a ocupar as páginas da mídia especializada internacional, sem que houvesse, por parte desses veículos de informação, outros trabalhos com maior afinco realizados no sentido de construir um aprofundamento sobre o panorama da nova arquitetura frente às dificuldades a serem enfrentadas pelo país. Por isso, o meio que difunde a arquitetura moderna desse período é o mesmo que a mantém sob as amarras de uma relação tributária entre países centrais e periféricos. Cf. CAVALCANTI, L. Moderno e Brasileiro: a história de uma nova linguagem na arquitetura, (1930-60). Rio de Janeiro, Jorge Zahar, 2006, p. 171.
} 
situação fez com que o arquiteto adotasse o que chamou de "atitude crítica em face da realidade". ${ }^{14}$

Uma reflexão que admite, inclusive, um conflito com alguns partidários do PC, pois não empunha uma bandeira de cunho "regionalista", tal como fazia m os "sectários" gaúchos, os quais, de acordo com Artigas, punham em xeque os "avanços técnicos" em relação ao concreto armado, indo contra os excessos formalistas da chamada "arquitetura carioca" e em favor da expressão de um sentimento popular. Este que, para eles, apenas se resumia em desenhar o "homem com laço e cavalo de fronteira", o que para Artigas era uma "visão pobre". 15

Ao mesmo tempo, Artigas não se rende aos valores plásticos, em que se converteu a arquitetura brasileira pelas mãos dos cariocas. Assim, sua defesa se comprometeria em buscar alternativas, mesmo frente às dificuldades de implantação do socialismo no Brasil, desde que os seus esforços rumassem para a reflexão dos limites e possibilidades dos preceitos modernos perante as contradições da cidade e do país e não se traduzissem como um retorno ao nosso passado colonial para a afirmação de uma "identidade nacional". Diante dessa postura, "o caráter local" da produção brasileira não diria respeito ao uso de recursos peculiares à tradição vernacular da arquitetura, pois, para Artigas (1988), essa condição também podia ser entendida como uma forma de servidão. Além disso, era incapaz de "valorizar o conhecimento" construtivo de outros momentos da história, tal como o trabalho dos mestres-de-obras do ecletismo.

\footnotetext{
${ }^{14}$ ARTIGAS, V. Os caminhos da arquitetura moderna. In: ARTIGAS, V. Caminhos da Arquitetura. São Paulo, Cosac Naify, 2004, p. 50. (artigo originalmente publicado em: Fundamentos, Revista de Cultura Moderna, São Paulo, n. 24, jan. 1952, p. 20-25).

15 ARTIGA S, V. As posições dos anos 50. In: ARTIGAS, V. Caminhos da Arquitetura. São Paulo, Cosac Naify, 2004, p. 154. (entrevista de Vilanova Artigas a Aracy Amaral realizada em 1980, originalmente publicada em: Projeto, São Paulo, n. 109, abr. 1988, p. 95-102).
} 
O que está em jogo, nesse momento, é a arquitetura moderna como afirmação da técnica, já que, no pensamento de Artigas, esta não exclui os ganhos conseguidos por todas as outras produções anteriores. Além disso, se a arquitetura brasileira fosse assim compreendida, poderia contribuir para um projeto coletivo, na medida em que buscasse os meios capazes de proporcionar uma solução que pudesse ser estendida para o processo de industrialização, do qual ainda se esperava fazer parte. ${ }^{16}$

$\mathrm{Na}$ verdade, depois da primeira viagem de Artigas à União Soviética (1953), a realidade da arquitetura desse país se mostrou "antiquada e de mau gosto" ${ }^{17}$, de acordo com um de seus companheiros na ida até Moscou. Houve, portanto, da parte de Artigas, uma decepção diante da resposta arquitetônica do socialismo soviético. O que reforçou sua busca pela experimentação das possibilidades da técnica do concreto armado, mesmo que estivessem ligadas, em um primeiro momento, ao âmbito burguês. Assim, se era preciso industrializar para fazer a "casa para todos", enquanto a indústria nacional não pudesse servir para constituição da habitação popular, seria mais honesto utilizar os recursos que as classes dominantes deixavam à disposição, que fingir resolver o problema. ${ }^{18}$

\footnotetext{
16 “[...] Sempre tive certeza de que haveria uma revolução proletária e que o desenvolvimento resultaria na criação de uma indústria nacional capaz de servir ao nosso povo e de propiciar o surgimento de uma classe operária, tal qual a pensada por Marx, que, acumulando um conhecimento geral e mais a modificação da estrutura decorrente, abria-se o caminho para o socialismo, enfim para uma sociedade mais elevada. O que se deu foi o contrário. As lideranças operárias formadas nos últimos anos não são exatamente iguais às que eu tinha imaginado". Cf. ARTIGAS, V. Depoimento. In: XAVIER, A. (Org.). Arquitetura Moderna Brasileira: depoimento de uma geração. São Paulo, Pini, 1987, p. 188. (artigo originalmente publicado em: A Construção São Paulo, São Paulo, n. 1910, p. 14-22, set. 1984).

${ }^{17}$ GORENDER, J. Expressão extraída do livro de João Masao Kamita. KAMITA, J. M. Vilanova Artigas. São Paulo, Cosac Naify, 2000, p. 123.

18 QUEIROZ, M. V. de. Arquitetura e Desenvolvimento. (artigo originalmente publicado em: Revista do Instituto de Ciências Sociais, Rio de Janeiro, (1): 171-198, 1962.). In: XAVIER, A. (Org.). Arquitetura Moderna Brasileira: depoimento de uma geração. São Paulo, Pini, 1987, p. 166.
} 


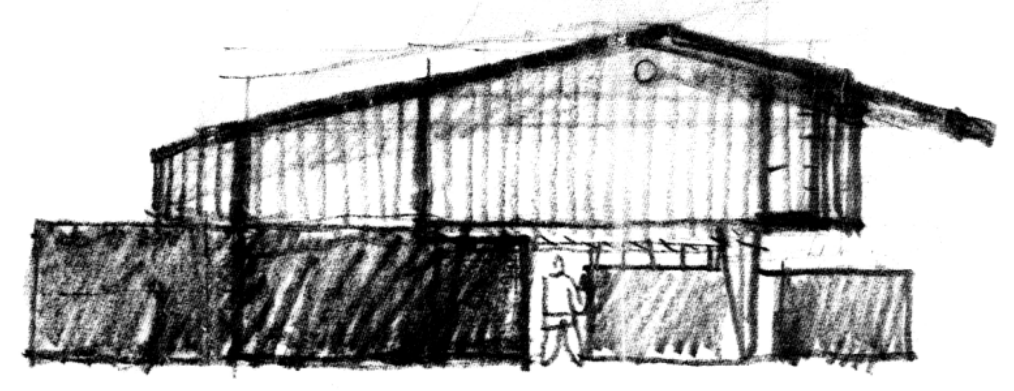

1.2. A postura política na opção pelo concreto armado 
Durante os anos de 1956-61, no governo de Juscelino Kubitschek, o Brasil assistirá o seu maior desenvolvimento econômico-industrial, vivenciando um momento único no que diz respeito ao volume de investimentos estrangeiros que financiarão as prioridades do Estado em infra-estrutura e o incremento do processo de industrialização. Os reflexos dessa dinâmica poderão ser evidenciados na cidade de São Paulo, uma vez que a capital paulista será a "porta de entrada do capital internacional". As transformações ocorridas nessa jovem metrópole, durante a década de 50, foram inúmeras, pois a concentração industrial e econômica, a rápida urbanização, a burocratização e a institucionalização das atividades se constituíram como “chave" da "modernização". 19

Nesses anos, segundo Regina Meyer (1991), irá se compor uma sociedade de massas configurada por uma série de contradições intermediadas, principalmente, pelo "modo periférico de expansão" da cidade paulista. Isto porque, a organização urbana de São Paulo na sola do sistema capitalista e envolta na promessa desenvolvimentista - foi engendrada por uma atividade especulativa sem precedentes, fazendo com que a classe trabalhadora fosse empurrada para as bordas, carentes de todo o tipo de infra-estrutura. Diante dessa situação, contrariamente ao que fora afirmado no discurso populista do Estado, a melhoria das condições de vida da população, apenas podia ser percebida às avessas.

Nesse caso, a aplicação do desenho moderno às medidas urbanísticas promoverá um sucessivo arrendamento da cidade, uma vez em que a lógica funcionalista agirá em benefício da constituição de um comércio do solo urbano. O trabalho de Feldman (1996) aponta que, durante a década de 50, haverá uma maciça demarcação das zonas funcionais em São Paulo,

\footnotetext{
${ }^{19}$ MEYER, R. M. P. Metrópole e Urbanismo São Paulo anos 50. São Paulo, tese de doutoramento apresentada à FAU-USP, 1991, p. 27.
} 
favorecendo a expulsão de possíveis "usos indevidos” em áreas valorizadas, o que também colaborou para o traçado dos bairros exclusivamente residenciais. ${ }^{20}$

No caso paulista, a casa operária - auto-construída - estava relegada ao imperativo de permanecer nas franjas urbanas, ao lado das indústrias, enquanto o ideário arquitetônico do Movimento Moderno era assimilado pelo ritmo acelerado de construção requerido pelo mercado imobiliário, sobretudo, em edifícios verticais sob pilotis, com grandes panos de vidro, localizados em áreas privilegiadas da cidade de São Paulo. Além disso, os signos característicos da arquitetura moderna configuravam peça importante na constituição de uma imagem "cosmopolita" e também, na incorporação dos novos condomínios destinados à burguesia paulistana. ${ }^{21}$

Nesse sentido, o trabalho de Artigas (1956) procurará questionar uma indevida apropriação da arquitetura moderna brasileira, já que esta havia se tornado parte de uma lógica comercial, na maneira como servia às necessidades dos lançamentos imobiliários, aflorando em São Paulo como uma alternativa de vida metropolitana, numa conformação citadina cada vez mais cercada pelas disparidades sociais. Artigas, contudo, acreditava que, aproveitando-se os meios técnicos apreendidos nas obras emblemáticas que foram erguidas pela chamada "arquitetura carioca", chegaríamos à consecução democrática da arquitetura.

O notório domínio da técnica do concreto armado encarnava, pela arquitetura brasileira, grande parte da esperança de Artigas em formular respostas contundentes na busca

\footnotetext{
20 FELDMAN, S. Planejamento e Zoneamento, São Paulo 1947-1972. São Paulo, tese de doutoramento apresentada à FAU-USP, 1996, p. 110.

21 "[...] A linguagem moderna - dos postulados de Le Corbusier que os arquitetos cariocas tão bem se apropriaram e desenvolveram -, vai sendo definitivamente incorporada no desenho dos edifícios [...]" paulistanos, porque ela "[...] facilitou a maior racionalização do processo construtivo pela padronização de elementos, pela modulação estrutural que otimizou o uso das fôrmas de concreto, pela concentração das prumadas hidráulicas e elétricas [...]". Cf. VILARIÑO, M. C. do. Habitação verticalizada na cidade de São Paulo dos anos 30 anos 80. Investigação acerca da contribuição dos arquitetos modernos ao tema. Estudo de casos. São Paulo, dissertação de mestrado apresentada à FAU-USP, 2000, p. 91. Vale ressaltar que são desse período os edifícios: Copan (1951), de Oscar Niemeyer, Conjunto Nacional (1955), de David Libeskind e Itália (1956), de Adolf Franz Heep, dentre outros.
} 
por uma solução para os "problemas da construção no Brasil". No entanto, ao mesmo tempo em que a relevância no manuseio desse material era, na fala de Artigas (1956), comparável à “dos países mais adiantados do mundo", também havia a consciência de que ainda convivíamos com inúmeros entraves conjunturais na nação que iam, desde os problemas de âmbito físico, até as deficiências no campo da educação e saúde.

Para Artigas (1956), a "audácia técnica" de nossa arquitetura se mostraria incompatível se o povo não pudesse se libertar do "atraso" em que vivia. Desta forma, para o arquiteto, seria ainda preciso superar uma "contradição básica" de nossa realidade social, porque enquanto tínhamos incontáveis riquezas e a possibilidade de expressar nosso conhecimento, demonstrando a "ousadia" nacional por meio da técnica, grande parte da população das cidades, especialmente a de São Paulo, estava renegada de sua própria organização urbana. ${ }^{22}$

Na postura de Artigas, a aceitação da técnica como solução para a superação dos problemas do país estava em constante conflito com a consciência da realidade díspar da população brasileira - um desacerto que, fatalmente, se espelhava no canteiro de obras, pois as próprias forças produtivas traduziam as nossas incongruências. A indústria ainda não era capaz de dar cabo do desdobramento técnico necessário para que os arquitetos pudessem buscar as saídas construtivas para atenuar os problemas de moradia.

De acordo com Artigas, a viabilidade da industrialização da construção era, de um lado, castrada por uma dependência da nossa matriz econômica aos interesses do capitalismo internacional e, de outro, por todo o grau de insuficiências incrustadas no país, sobretudo, a tecnológica. Na visão do arquiteto, ao lado da peleja para a independência econômico-social

\footnotetext{
22 ARTIGAS, V. Aos Formandos da FAUUSP. Discurso de Paraninfo na colação de grau dos arquitetos formados pela FAUUSP em 1955. In: ARTIGAS, V. Caminhos da Arquitetura. São Paulo, Cosac Naify, 2004, p. 62. (texto originalmente publicado em: AD Arquitetura e Decoração, São Paulo, ano 4, n. 17, maio/jun. 1956).
} 
do Brasil, havia também o posicionamento nevrálgico de escancarar os contrates de toda a ordem que se faziam presentes na concreção da arquitetura moderna, de modo que estes pudessem vir à tona, contribuindo, assim, para uma atitude crítica em face da realidade. Por esse motivo, na percepção de Artigas, enquanto Niemeyer se esforçava "para resolver as contradições numa síntese harmoniosa", ele as expunha claramente, já que em sua opinião: "[...] o papel do arquiteto não consiste numa acomodação", na medida em que "[...] não se deve cobrir com uma máscara elegante as lutas existentes, é preciso revelá-las sem temor". ${ }^{23}$

Nesse sentido, Artigas (1956) irá constituir, em alguns projetos de residências voltados para a classe intelectual, uma radical oposição aos aspectos estéticos modernos que formulavam o gosto burguês. Se o domínio dos meios de produção não estava à disposição, restava experimentar possibilidades que pudessem levar na direção de uma emancipação cultural, pois, na opinião do arquiteto, promovendo-se uma reinvenção do espaço da casa burguesa, também estaria sendo gestada uma arquitetura que pudesse servir para fins mais nobres.

Artigas imaginava que nessas residências poderia, em termos técnicos, conseguir resolver os problemas da casa popular, além de antecipar as modificações sociais desejadas. Nas casas burguesas também era possível denunciar os contra-sensos do país. O projeto da casa Olga Baeta (1956-57), no bairro do Butantã, em São Paulo, é uma prova desse escopo, pois suas empenas conformam um prédio cerrado que rechaça a rua, se opondo à desvirtuação do discurso funcionalista em relação à cidade, formulando, assim, uma nova concepção espacial.

\footnotetext{
${ }^{23}$ ARTIGAS, V. Depoimento a Yves Bruand. In: BRUAND, Y. Arquitetura Contemporânea no Brasil. São Paulo, Perspectiva, 1981, p. 302.
} 

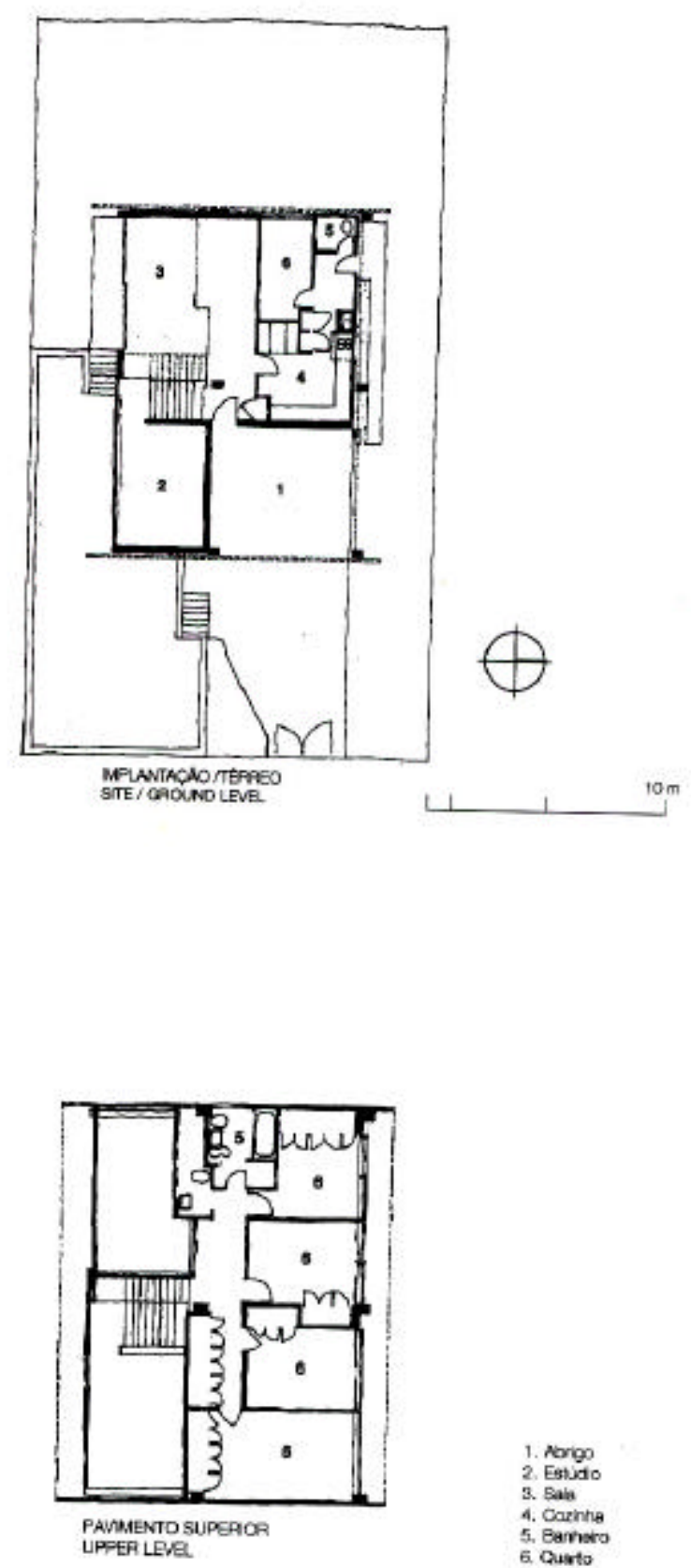

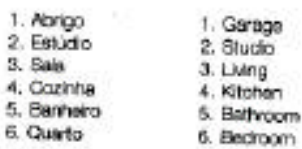

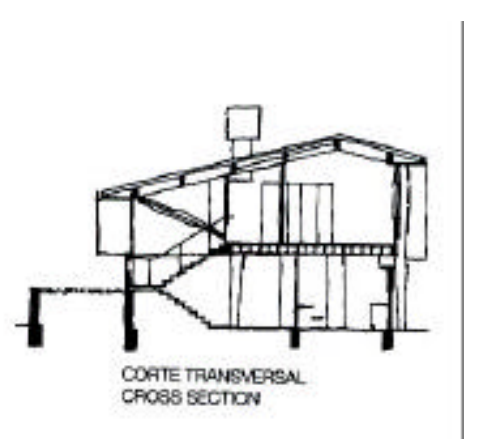

Figura 10 - Casa Olga Baeta, 1956, projeto. Fonte: Artigas (1997, p. 73). 
Diante dessa leitura, a casa Olga Baeta busca romper com uma inter-relação com o entorno porque, ao contrário da liberdade formal dos desenhos sinuosos das marquises e das transparências que propunham a ligação interior-exterior, as empenas cegas de sua construção configuram fachadas iguais, rebatendo os valores plásticos como forma de distinção. Sendo assim, essa obra constitui um volume que refuta a paisagem, mantendo certo distanciamento dela, cindindo as mais emblemáticas características dos projetos edificados pelo repertório dos cariocas, até as suas assimilações pelo mercado imobiliário paulistano.

Em seu recolhimento, a casa Olga Baeta se fecha sobre suas elevações. Apenas suas laterais são fendidas, mas, mesmo assim, demarcadas pelo exíguo terreno. Então, perante essa espacialização, Artigas buscará não apenas demonstrar a inadequação de se constituir uma arquitetura em contato com o exterior, devido à especulação do solo urbano, mas também procurará por uma ocupação mais racional da casa, em uma cidade empreitada pelo capital. Desse ponto de vista, Artigas destitui a tradicional compartimentação da residência burguesa, abolindo a garagem como "cocheira" e as dependências de serviço como edificação separada, de modo a unificá-las ao corpo da casa.

Essa tentativa de atualização da habitação à vida contemporânea já vinha sendo experimentada em alguns projetos anteriores de Artigas, mas, no projeto da casa Olga Baeta, assumirá uma constituição que altera a percepção dos novos materiais, inclusive, da técnica moderna. Ao inverso dos arranjos com grandes plano s de vidro de outrora, o concreto armado agora deflagra, na empena cega, as objeções de Artigas em relação às agruras do contexto urbano e à opressão do sistema vigente, traduzindo-as em uma inversão do próprio sentido de progresso requerido. 


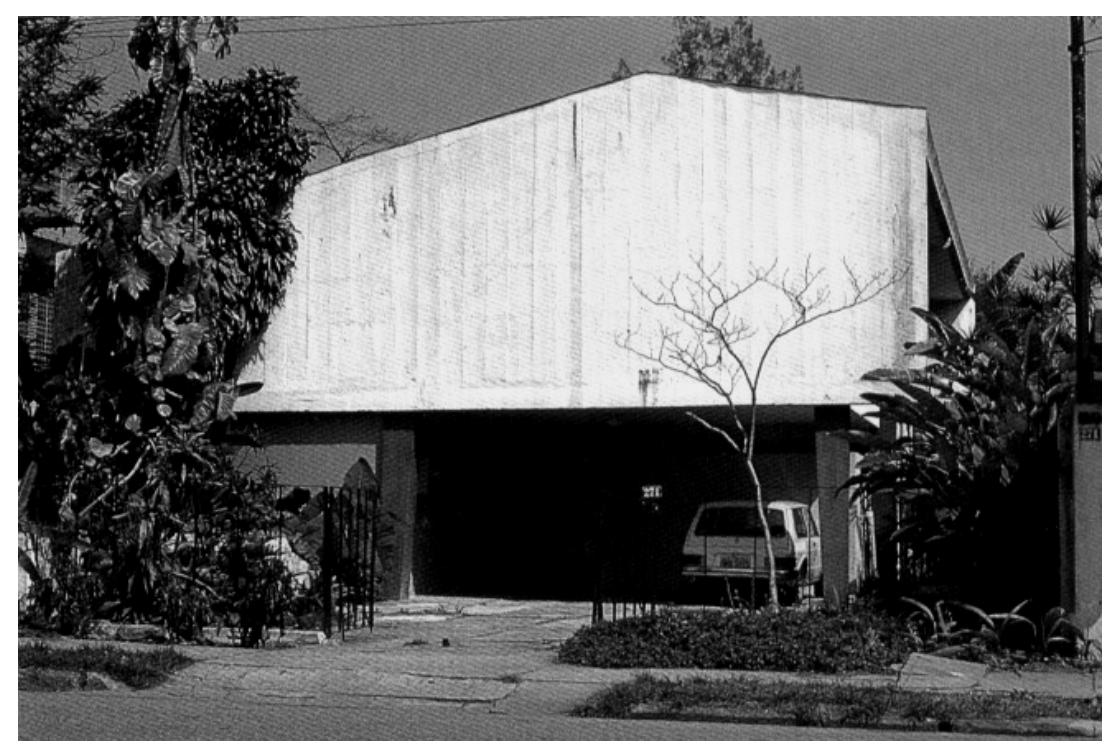

Figura 11 - Casa Olga Baeta, 1956, exterior, frente. Fonte: Artigas (1997, p. 73).

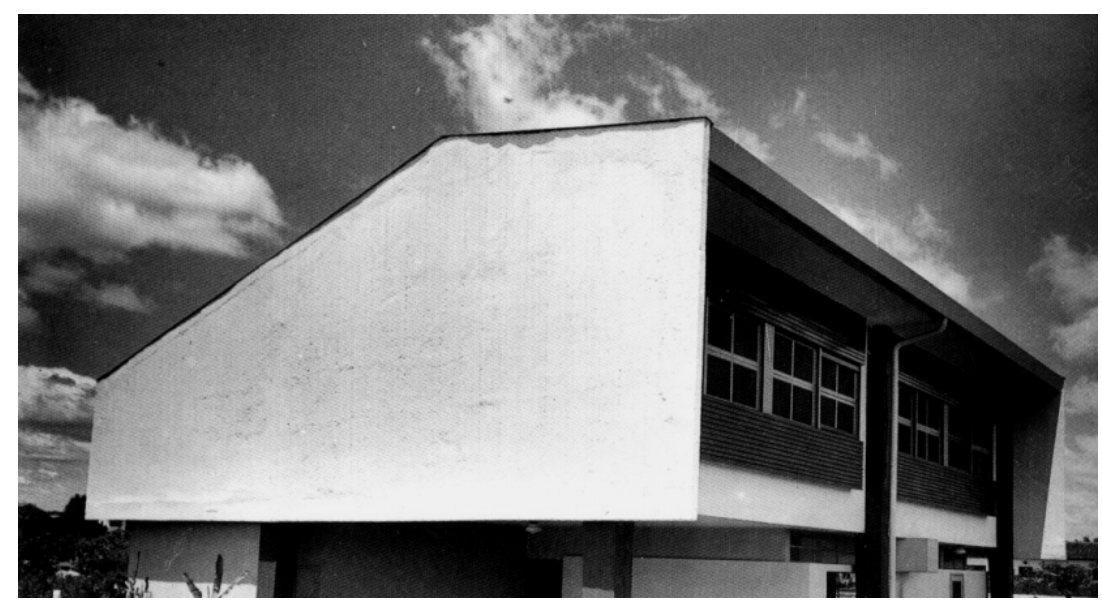

Figura 12 - Casa Olga Baeta, 1956, exterior, fundos. Fonte: Artigas (1997, p. 73).

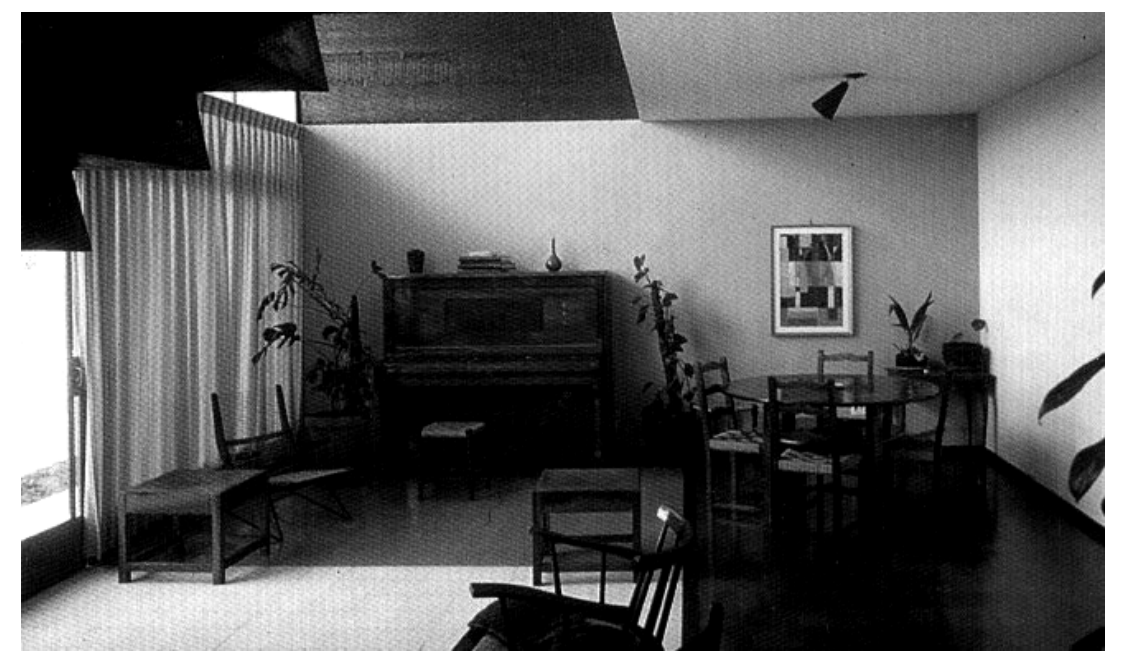

Figura 13 - Casa Olga Baeta, 1956, interior. Fonte: Artigas (1997, p. 73). 
A grande empena frontal da casa Olga Baeta é uma forma de contestação, porque atesta as peculiaridades do seu método de construção, já que a madeira grossa que havia sido utilizada como fôrma, quando retirada, revelou um resultado "hediondo", segundo Artigas (1997). Os elementos e os procedimentos empregados na cura do concreto dessa obra, enquanto derivam dos avanços conseguidos pela arquitetura brasileira, não escamoteiam nossas mazelas, pautadas, sobretudo, na imprevisibilidade e no arremedo.

As imperfeições de uma arquitetura produzida manualmente, ao contrário do ideário mecanicista, passam a ser a tradução do arcaísmo dos materiais empregados, das falhas originadas no processo construtivo e das adversidades enfrentadas pela baixa qualidade da mão-de-obra. Dessa maneira, as desventuras para a consecução de uma mudança de paradigma passam a ser parte visível das discrepâncias presentes na condição socioeconômica do país. Logo, as ranhuras deixadas no concreto armado da casa Olga Baeta são, neste momento, índices da nossa realidade de despautérios. Desse modo, essa obra de Artigas estilhaça a imagem polida dos grandes baluartes da produção nacional difundida pela mídia internacional, expressando também uma reação às convenções de catálogo.

Todavia, apesar desse teor contestatório, o projeto da casa Olga Baeta, em seu interior, admite aproximações com as idéias de um espaço contínuo, mantendo forte ligação com os pressupostos das vanguardas européias do início do século XX. Assim, o piso todo colorido dos ambientes sociais, tal como um quadro de Mondrian, subentende uma divisão do espaço que se pressupõe em suspenso, promovendo uma constante interpenetração das funções composição que pode sugerir uma materialização do traço neoplasticista, presente na Maison Particulière (1923), dos arquitetos do De Stijl.

Embora essa conotação não seja explicitada, é possível que contenha, em seu bojo, uma vontade de formulação de um espaço coletivo. Desse modo, enquanto a cidade não podia 
ser a expressão desse ideário, o espaço da casa tenderia a assumir essa qualidade, já que o concreto armado possibilitava que as paredes estruturais fossem abolidas, fazendo do antigo interior burguês - até então subdivido em muitos cômodos -, um amplo espaço destinado ao uso comum. Essa espacialização pretendia a recondução das relações sociais, uma vez em que, nas palavras de Artigas, a "relação de visualidade do total do espaço" compreendia um desejo de "educação da família". ${ }^{24}$

Dessa maneira, se, externamente, o projeto da casa Baeta se apresentava austero e em oposição à cidade, internamente, o seu espaço despojado e acolhedor se pretendia instrutivo do ponto de vista de uma moradia. Artigas acreditava, portanto, que a residência unifamiliar, desprovida de esnobismos poderia servir como um instrumento de caráter pedagógico que, ao longo do processo do desenvolvimento da nação, poderia ser a semente revolucionária capaz de dotar o espírito burguês do sentido reformador de toda a sociedade.

Entretanto, ainda que uma função educativa estivesse presente no cerne da arquitetura moderna, a adoção da continuidade espacial como conceito que corroborasse para a democracia e a apropriação de formas nuas como artifício para uma padronização, nunca haviam sido pensadas para que a burguesia pudesse se somar à causa coletiva, mas sim, o contrário. Nesse sentido, esse empenho de Artigas também poderia corresponder à vã tentativa de politização do usuário. Mesmo assim, sua proposição visualizava, incubada na casa burguesa, a possibilidade de uma reviravolta. ${ }^{25}$

\footnotetext{
${ }^{24}$ ARTIGAS, V. Vilanova Artigas: arquitetos brasileiros. São Paulo, Instituto Lina Bo e P. M. Bardi / Fundação Vilanova Artigas, 1997, p. 72.

25 " [...] Pode-se dizer que, ao contrário dos países centrais, o desenho moderno não era uma das consequiências da revolução burguesa, mas sim anterior a ela, pretendendo antecipá-la. Ou seja, [no Brasil] se o desenho ainda não atingira todas as classes, dirigia-se ao menos à parcela da elite que, naquele momento, era entendida como capaz de realizar as reformas democráticas e a ruptura anti-imperialista." Cf. ARANTES, P. F. Arquitetura Nova: Sérgio Ferro, Flávio Império e Rodrigo Lefèvre, de Artigas aos mutirões. São Paulo, Editora 34, 2002, p. 37.
} 
Por conta disso, a racionalidade construtiva era tida, por Artigas, como solução para baratear o custo da obra. A sistematização modular procurará revelar o uso mínimo de apoios para a economia de meios. A prova desse intento são as colunas da casa Olga Baeta que tiram partido da contenção por meio de um desenho enviesado, pois como se sabe, os esforços requeridos na junção entre pilar-viga-laje são sempre mais elevados, requerendo, assim, maior robustez da armadura de concreto exatamente nesse ponto de encontro.

Nesse caso, a resposta arquitetônica da casa Olga Baeta depende, essencialmente, da adaptabilidade no trato da técnica. Os seus seis pilares e as duas empenas em balanço constituem a apropriação do concreto armado como uma saída frente aos obstáculos, almejando que se constituam formas que possam reverter a débâcle social do país. Uma ação engendrada sempre em conflito, porque enquanto firma um pacto com a burguesia progressista para elaborar um desenho-desígnio, não se aproxima do povo.

A casa construída por Artigas se mantém como um ensaio utópico, que tem como cerne a aura de um objeto dessacralizante, pois, se até então, não podia servir para a concreção de uma nova sociedade, era prenhe de significado político, materializado pelas aflições do arquiteto diante da disparidade que assolava a realidade brasileira, na vontade de dirimir o sofrimento da população. Nesse sentido, as empenas que Artigas projeta em concreto armado deflagram a sua ativa participação na idéia de alterar o curso do país, mesmo que sob a tutela de um desenho destinado à burguesia. ${ }^{26}$

Deste modo, Artigas segue com a idéia da elaboração da "ossatura" do edifício como uma “expressão formal do projeto". Na casa Rubem de Mendonça (1958), também conhecida como a "casa dos triângulos", o empenho de Artigas estará em revelar a estrutura como parte

\footnotetext{
${ }^{26}$ Por seu valor histórico, o sobrado foi comprado no final da década de 1990, pelo irmão do arquiteto Ângelo Bucci, que também promoveu sua adaptação e reforma. Cf. TEIXEIRA, C; BAVA, C. Dos anos 50 aos 90 . Casa Baeta. Arquitetura \& Construção, São Paulo, n. 03, p. 28-37, mar. 1998.
} 
primordial da pesquisa arquitetural. Logo, o que na casa Olga Baeta eram apenas colunas enviesadas, na casa Rubem de Mendonça, se converte numa insígnia presente em todos os espaços - uma tradução das possibilidades do concreto armado na constituição plástica do edifício racionalizado. Nesse sentido, como uma maneira de deflagrar essa preocupação, é agregado, à fachada dessa casa, um grande mural, elaborado juntamente com o artista Mário Gruber, na tent ativa de fazer ver "uma nova linguagem". 27
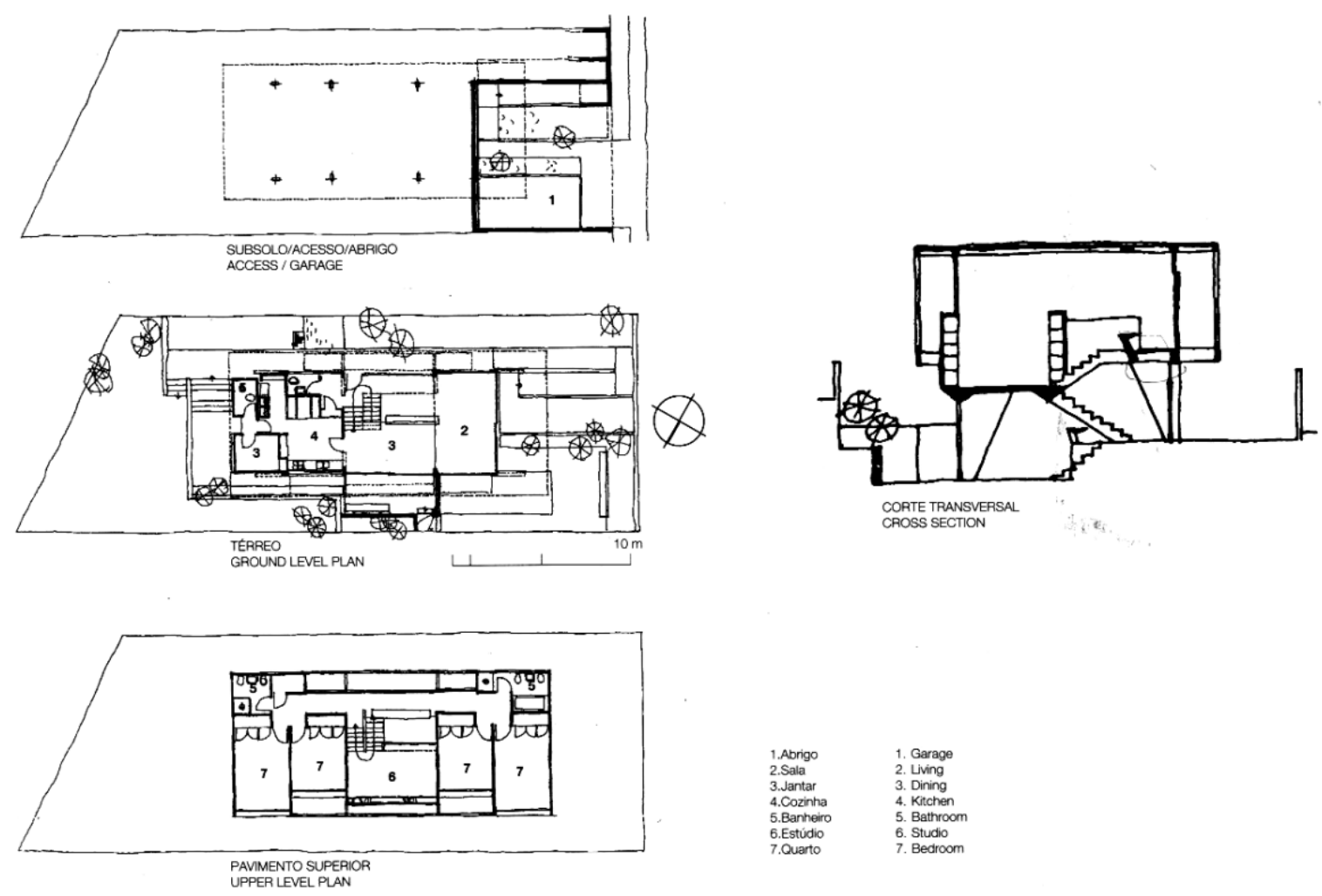

Figura 14 - Casa Rubem de Mendonça, 1958, projeto. Fonte: Artigas (1997, p. 79).

\footnotetext{
27 ARTIGAS, V. Vilanova Artigas: arquitetos brasileiros. São Paulo, Instituto Lina Bo e P. M. Bardi / Fundação Vilanova Artigas, 1997, p. 78.
} 

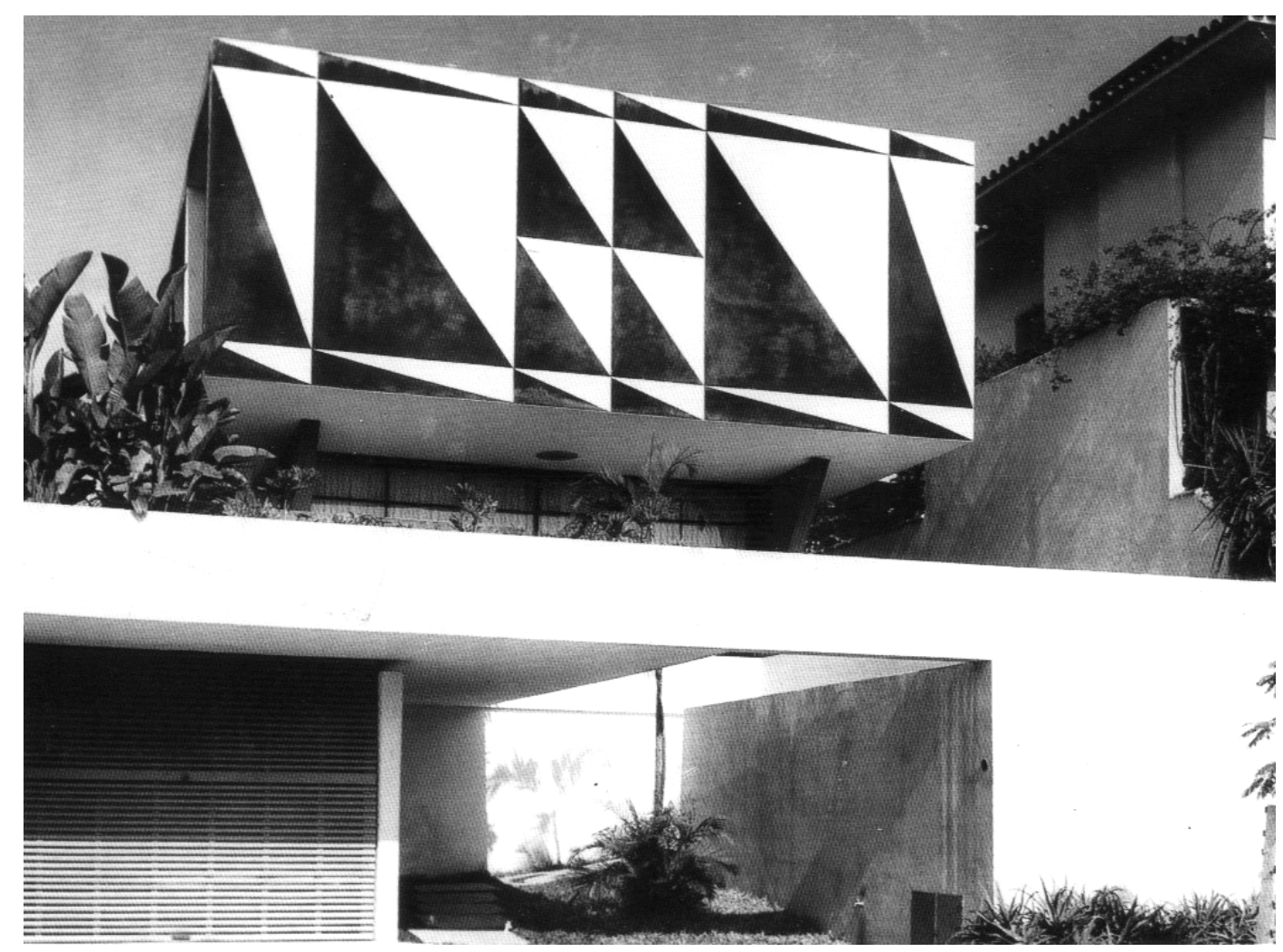

Figura 15 - Casa Rubem de Mendonça, 1958, exterior, frente. Fonte: Artigas (1997, p. 80).

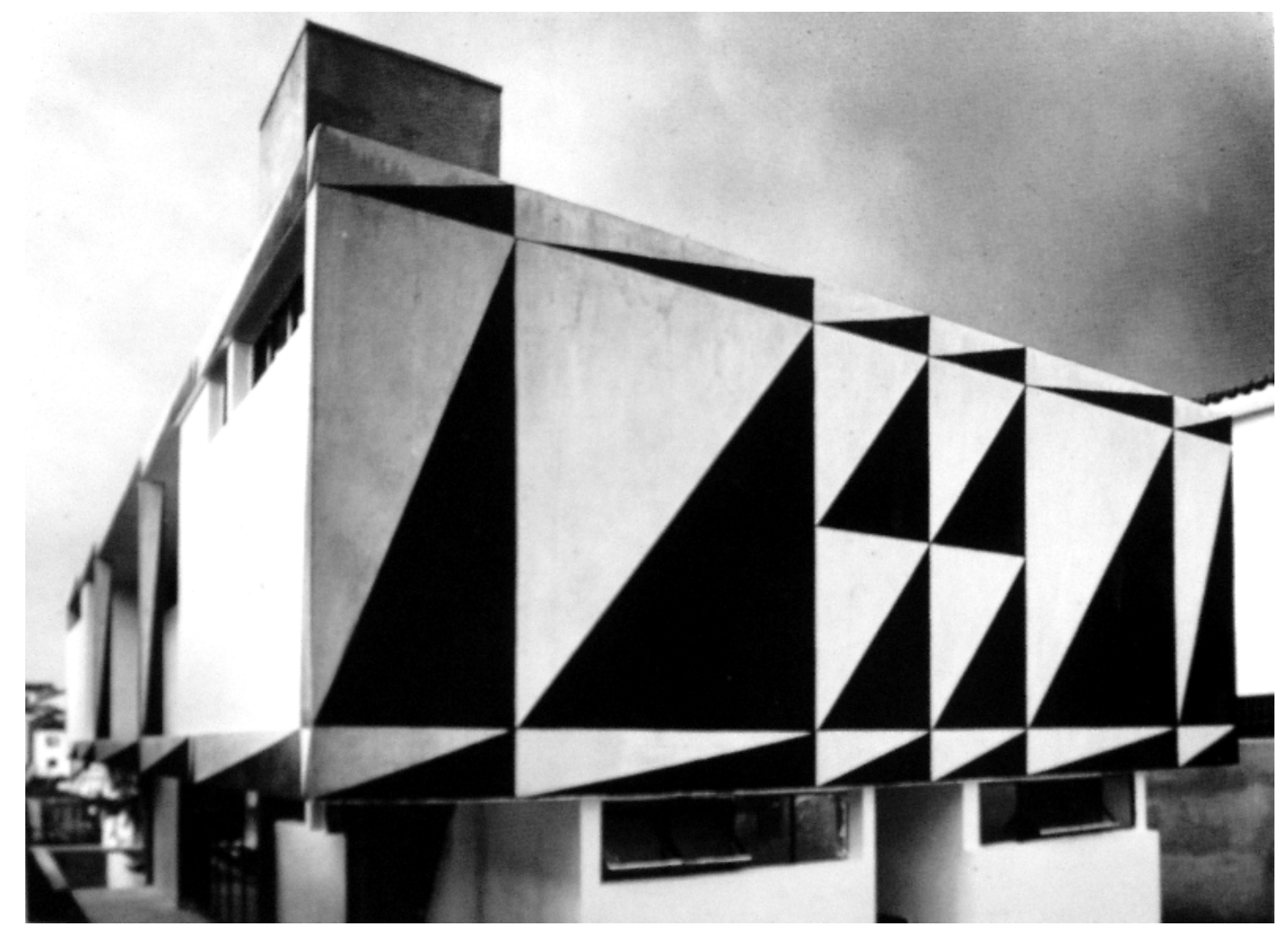

Figura 16 - Casa Rubem de Mendonça, 1958, exterior, fundos. Fonte: Artigas (1997, p. 79). 
Esta proposta acaba por expor, ao inverso de um volume opaco, uma superfície transparente, porque, apesar da grande empena cega se compor como uma barreira visual para o interior da casa, o afresco incrustado ao concreto armado, constituído por "triângulos concretistas azuis", tende a funcionar como espécie de quadro explicativo que comunica, ao exterior, a lógica do partido da residência. Dessa proposição, emana a interação dúbia entre o lado de dentro e o de fora da casa que, simultaneamente, vela e desvela as vísceras do projeto.

A composição dos triângulos da elevação principal da casa Rubem de Mendonça se refere então aos elementos portantes do bloco residencial, dimensionados por uma severidade construtiva. As suas formas enviesadas não são, portanto, mera elaboração estética, mas uma apropriação rigorosa dos recursos disponíveis para evitar, ao máximo, o desperdício. Sendo assim, a mensagem subliminar constituída como imagem abstrata informa, agora, o compromisso de Artigas com uma nova ética que confronta os valores puramente plásticos, buscando restabelecer a importância estrutural na concepção da arquitetura.

Essa preocupação de Artigas ganha maior reverberação quando da publicação da autocrítica de Oscar Niemeyer, em 1958. Esse momento culmina com a construção de Brasília, no qual o arquiteto carioca fará seu próprio balanço da arquitetura moderna brasileira, preconizando o "lastro social" e rechaçando sua possível desvirtuação. Nesse sentido, Oscar Niemeyer reconhece os desvios da produção arquitetônica nacional que, indubitavelmente, partiram de sua obra - muito ligada a uma excessiva originalidade - e sinaliza as possibilidades para um novo caminho, o da "própria estrutura, devidamente integrada na concepção plástica". ${ }^{28}$

\footnotetext{
${ }^{28}$ NIEMEYER, O. Depoimento. In: XAVIER, A. (Org.). Arquitetura Moderna Brasileira: depoimento de uma geração. São Paulo, Pini, 1987, p. 222. (publicado originalmente em: Módulo, Rio de Janeiro, n. 9, fev. 1958, p. 3-6).
} 
Nesse mesmo ano, Artigas prontamente escreve o artigo no qual consolida uma espécie de reconciliação com o trabalho de Oscar Niemeyer, deixando claro o que será o âmago da produção arquitetônica paulista nessa etapa. Aponta sua repulsa quanto a "certos aspectos decorativos" que passaram a caracterizar a expressão da arquitetura nacional, ratificando o discurso do arquiteto carioca. Artigas afirma o sentido do seu traço, numa concepção do edifício como estrita tradução de sua estrutura, "capaz de novas e mais elevadas manifestações formais". 29

A partir daí, a necessidade de implementar um maior domínio técnico passará a ser a chave argumentativa de Artigas (1959a), pois, para o arquiteto, com essa premissa, seria possível revelar não apenas uma distinção da produção brasileira num contexto dualizado por países centrais e periféricos, mas, também, resolver os problemas sociais da nação. Na opinião de Artigas, para que a arquitetura fosse a "expressão cultural de um povo" de modo a exercer uma "influencia criadora", precisaria se servir do "avanço técnico" e da "produção industrial".

O trabalho de Artigas nos próximos anos estará comprometido com a busca de "novas formas" e "novas estruturas", derivadas da capacidade de conciliar a prática arquitetônica no manuseio do concreto armado à tarefa da racionalização. Assim, sua responsabilidade era refutar o "aproveitamento de valores estrangeiros" e se adiantar na invenção de desenhos “tecnicamente justificáveis”. Estes, para ele, evitariam incorrer nos erros do passado, abrindo os caminhos para a industrialização da construção e para a superação do “subdesenvolvimento". 30

\footnotetext{
29 ARTIGAS, V. Revisão Crítica de Niemeyer. In: ARTIGAS, V. Caminhos da Arquitetura. São Paulo, Cosac Naify, 2004, p. 100. (artigo originalmente publicado em: Acrópole, n. 237, São Paulo, ano 20, p. 420, jul. 1958). ${ }^{30}$ ARTIGAS, V. Aos formandos da FAUUSP. Discurso de Paraninfo na colação de grau dos arquitetos formados pela FAUUSP em 1958. In: ARTIGAS, V. Caminhos da Arquitetura. São Paulo, Cosac Naify, 2004, p. 73. (texto originalmente publicado em: Acrópole, São Paulo, ano 21, n. 244, p. 125, fev. 1959).
} 


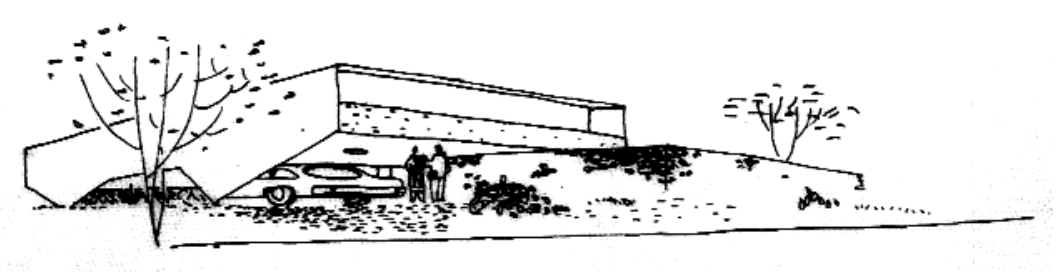

1.3. Do bloco único à grande cobertura 
O projeto da casa Taques Bitencourt (1959) se constitui numa obra chave do trabalho de Artigas, pois arranja o espaço destinado à residência em uma unidade. A ala social, as dependências de serviço e a área íntima estão circunscritas em um volume encerrado no terreno que se dispõe em torno de um pátio central. Essa organização do programa habitacional concebida em uma só massa garantiria uma concisa formalização geométrica, evitando as chamadas "edículas" e um máximo aproveitamento dos limites do lote, diante do regime vigente de propriedade da terra.

Então, esse exame projetivo corresponde a duas preocupações de Artigas: a primeira, tem o intuito de racionalidade construtiva, pois a casa configura um sistema estrutural preciso que busca a eliminação dos excessos e a padronização das peças em concreto armado e a segunda questão está ligada à procura pela otimização espacial do traçado da cidade de São Paulo, já que o bloco único poderia ser capaz de "concorrer para uma reorganização dos bairros residenciais" lidos, pelo arquiteto, como tendo um "aspecto anárquico". ${ }^{31}$

A concepção da casa Taques Bitencourt expressa o otimismo de Artigas em encontrar novas soluções para um reordenamento da sociedade e da cidade. No entanto, não deixa de evidenciar os conflitos do arquiteto em relação à opressão social, que podem ser lidos na oposição entre as empenas laterais da casa que encerram as extremidades do lote, evitando o contato com a vizinhança e a fachada frontal que, apesar dos caixilhos de vidro que promovem insolação e ventilação, não permite a visão do que acontece em seu interior.

O muro de pedras que se ergue defronte à calçada é mais um obstáculo que impede a intermediação entre os lados de dentro e de fora. Assim, a impressão que se tem é a desse elemento se configurar como um entrave para o exterior, já que está colocado sobre o perímetro da lavanderia e dependências de serviços, dispostas no subsolo, cujas aberturas se

\footnotetext{
31 ARTIGAS, V. Vilanova Artigas: arquitetos brasileiros. São Paulo, Instituto Lina Bo e P. M. Bardi / Fundação Vilanova Artigas, 1997, p. 82.
} 
organizam em sua base - ladeada por uma esguia depressão resultante do manejo da topografia e do feitio de um talude. Um arranjo que se constitui como uma trincheira para a rua.
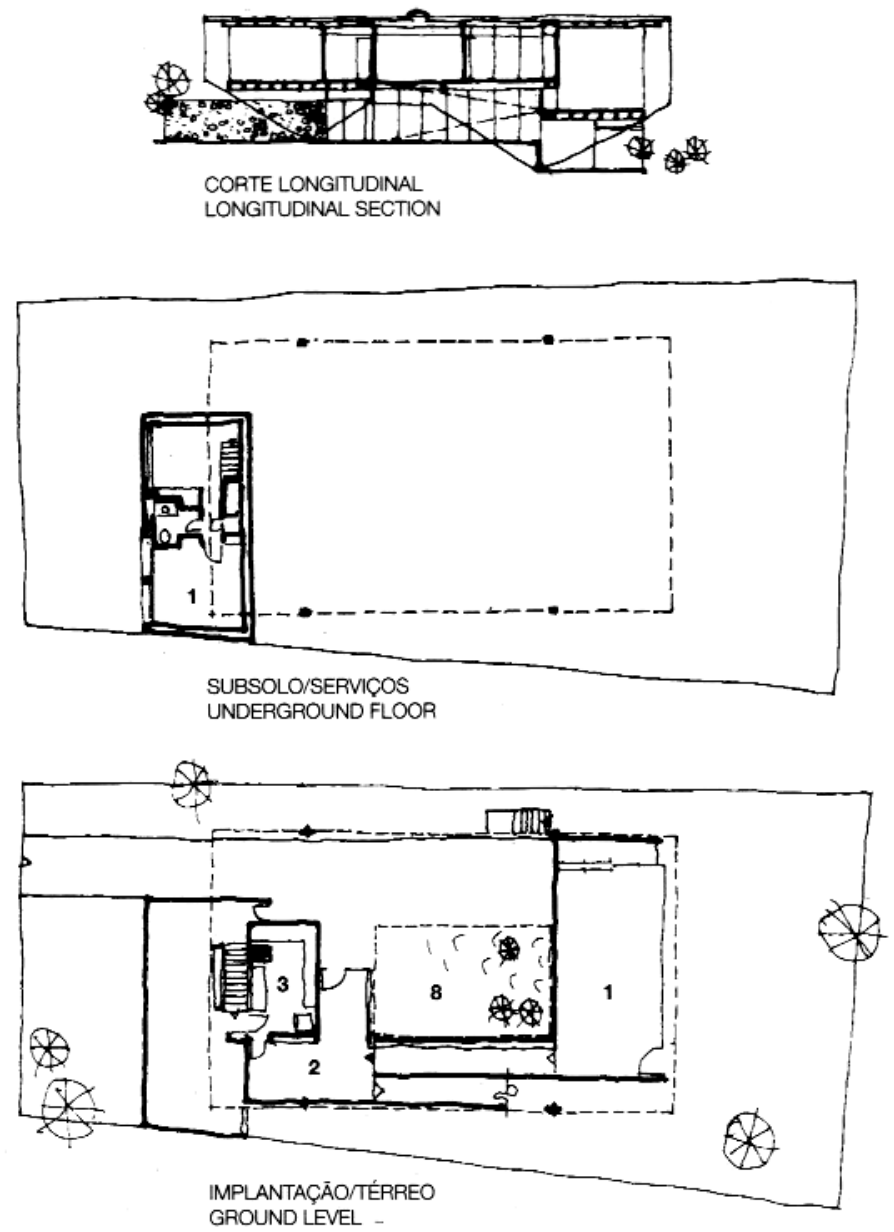
UUNDLEL -
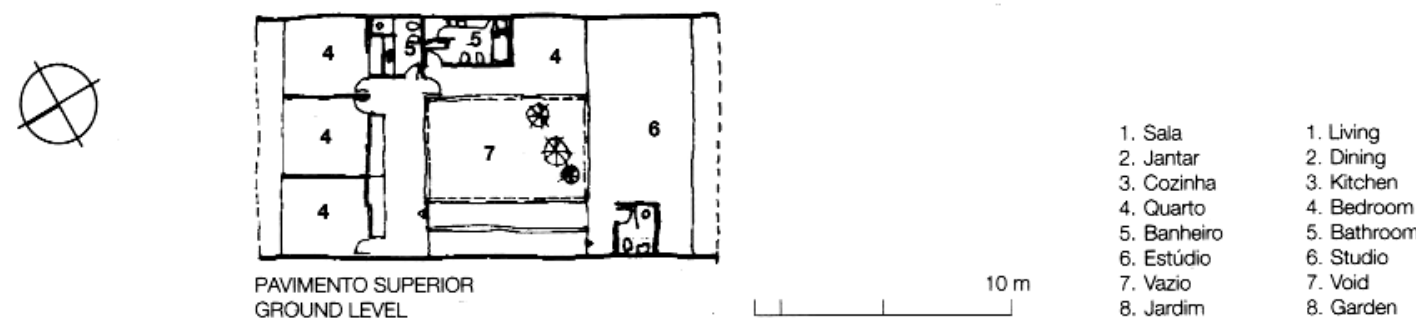

Figura 17 - Casa Taques Bitencourt, 1959, projeto. Fonte: Artigas (1997, p. 82). 


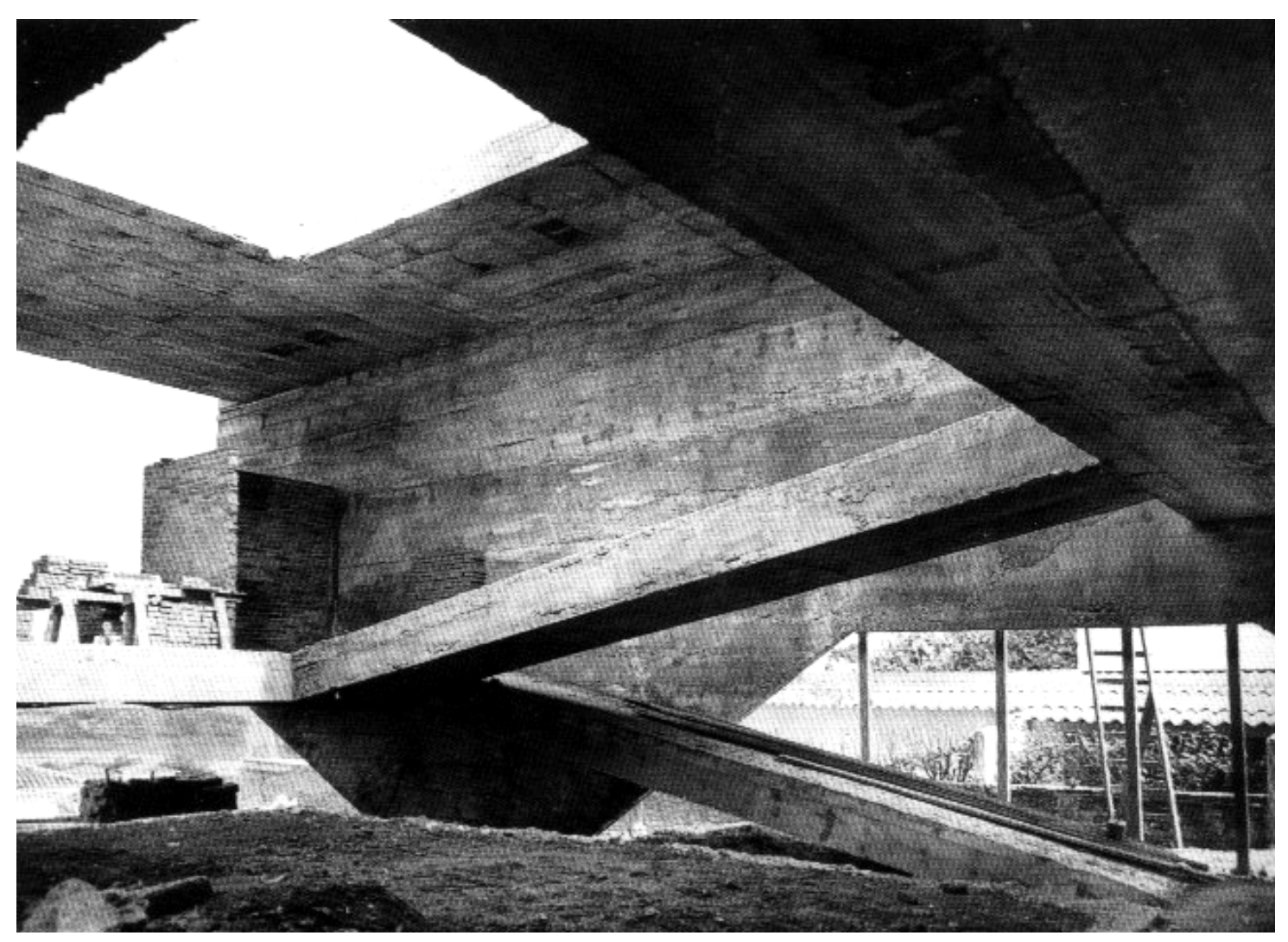

Figura 18 - Casa Taques Bitencourt, 1959, estrutura. Fonte: Artigas (1997, p. 82).

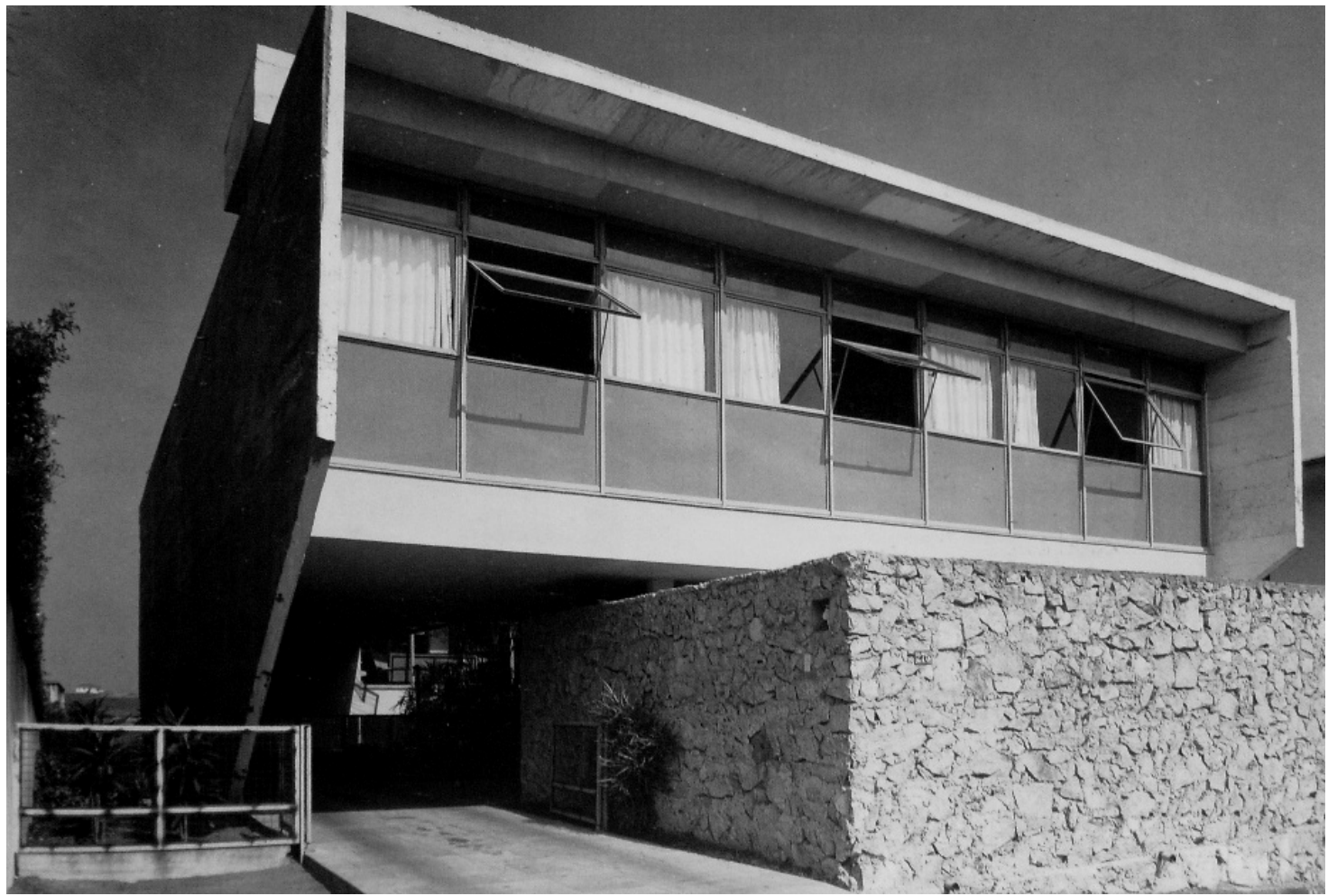

Figura 19 - Casa Taques Bitencourt, 1959, exterior. Fonte: Artigas (1997, p. 83). 
Ao inverso da $2^{\mathrm{a}}$. casa de Artigas que pousa sobre uma área arborizada e procura abarcar a paisagem ao seu redor, a casa Taques Bitencourt se ajusta por entre o exíguo terreno característico do loteamento paulistano, porque o contexto passa a ser tratado como algo a ser contraposto. Nesse caso, enquanto, externamente, essa construção funciona como bloco cerrado em pedra e concreto, internamente, se constitui como um espaço fendido que rompe hierarquias, buscando constituir um horizonte possível.

Sob o vão da casa Taques Bitencourt, o espaço comum se constitui, apesar de inerente à esfera familiar. Dessa maneira, essa construção em concreto armado é a senda que constituirá um novo partido arquitetural, como possibilidade de concreção dos ideais coletivos apregoados por Artigas. Ensaio de um recinto para uma "sociedade democrática" justificado como prática arquitetônica, supostamente capaz de articular princípios mais dignos - um "modelo ideal". 32

Nesse ambiente ideado da casa Taques Bitencourt, o interior também faz as vezes de exterior, como pode ser atestado pelo painel de cerâmica criado por Francisco Brennand localizado externamente na lateral da porta de entrada, porém paralelo ao acesso realizado pela garagem. Assim, se na casa Rubem de Mendonça, o mural estava presente na fachada, mediando uma relação com o espaço público, nesse projeto, a concepção do artista se volta para o lado de dentro, informando o edifício fechado que, em seu âmago, contraditoriamente, se pretende como um lugar aberto.

Desse modo, o espaço adquire certa amplitude devido à aeração e iluminação vindas do jardim nuclear e da fluidez do espaço interno. A continuidade espacial passa a se dar pelas rampas que intercomunicam os pavimentos e por planos de vidro voltados para um rígido

\footnotetext{
32 SEGAWA, H. Arquiteturas no Brasil: 1900-1990. São Paulo, Edusp, 2002, p. 151. Devo as premissas iniciais desse trabalho à discussão realizada por Hugo M. Segawa, sobre a difusão da "arquitetura paulista" como "modelo", a partir da obra de Vilanova Artigas.
} 
polígono verde. Nele, se constitui uma natureza artificializada, seja pela vegetação retificada ou mesmo pela filtragem da luz. Um continuum conseguido pela introversão, em repulsa ao entorno - uma inversão dos pressupostos modernos das primeiras habitações funcionalistas de Artigas que se voltam para o exterior.

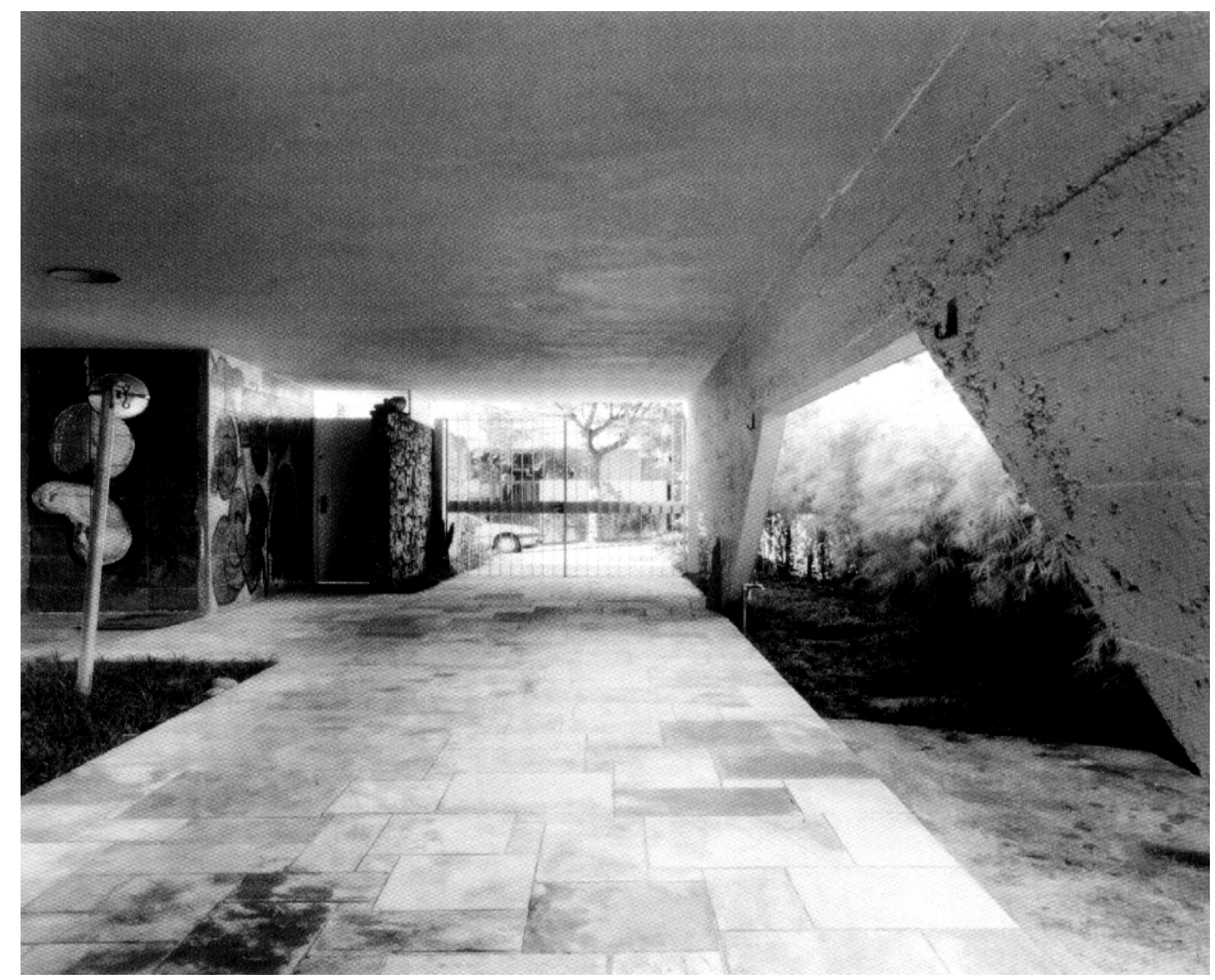

Figura 20 - Casa Taques Bitencourt, 1959, interior, garagem. Fonte: Kamita (2000, p. 70).
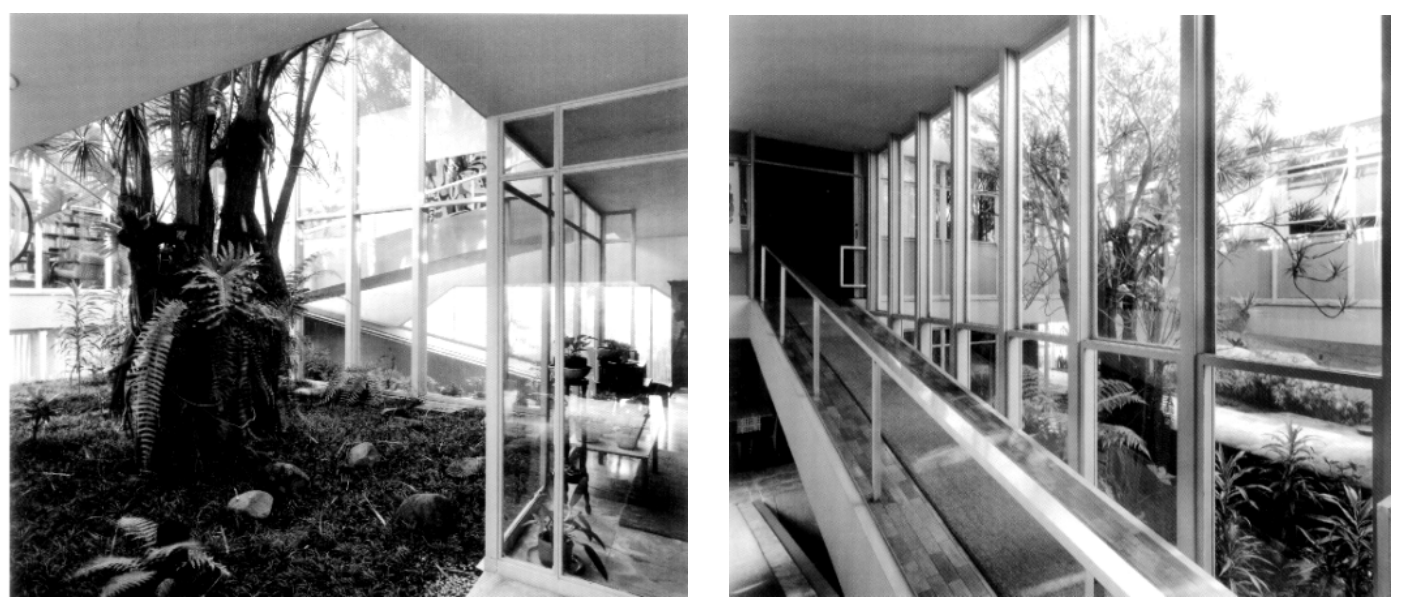

Figura 21 e 22 - Casa Taques Bitencourt, 1959, interior. Fonte: Kamita (2000, p. 72). 
Na casa Taques Bitencourt, a laje se converte em um plano que se dobra, já que as colunas que suspendiam o edifício do solo são reduzidas a duas empenas que funcionam, ao mesmo tempo, como uma viga-pilar, apoiando-se em apenas quatro pontos. A diminuição, ao mínimo, dos elementos essenciais para uma edificação parar de pé, compõe, assim, uma estrutura "standard". Desse modo, ao refutar o "caráter estético" e valorizar a "técnica estrutural", Artigas imagina imprimir, às formas construtivas, "as características culturais nacionais", buscando "canalizar para a indústria da construção a influência de sua atividade criadora". 33

A casa Taques Bitencourt torna possível o desejo de configurar um partido que fosse extensivo a outros programas, sobretudo pela racionalização estrutural. Nesse sentido, mesmo sem as mudanças requeridas pela área social, a forte crença no desenvolvimento da nação, por meio do incremento da industrialização, irá sustentar a promessa de que a técnica, evidenciada pela economia de meios, encadearia a sistematização de componentes em concreto armado, solucionando o problema da casa popular.

Apesar dos contra-sensos desse comprometimento, foram feitas tentativas de transportar os resultados obtidos no conjunto estrutural da casa Taques Bitencourt para obras com uma envergadura coletiva. Assim, a laje fundida aos apoios triangulares que pousam sobre o terreno passa a ser um esquema para a solução da grande cobertura. De tal sorte que, segundo Acayaba (1985), a casa Mário Taques Bitencourt pode ser entendida como a origem do "edifício público". ${ }^{34}$

\footnotetext{
33 ARTIGAS, V. Arquitetura e Cultura Nacionais. In: ARTIGAS, V. Caminhos da Arquitetura. São Paulo, Cosac Naify, 2004, p. 75. (aula inaugural ministrada na Faculdade de Arquitetura e Urbanismo da Universidade Federal do Rio Grande do Sul em 1959. Publicado em: Cadernos de Estudos, Porto Alegre, Centro dos Estudantes Universitários de Arquitetura, n. 6, 1959).

${ }^{34}$ ACAYABA, M. M. Vilanova Artigas, amado mestre. Tendências Atuais da Arquitetura Brasileira: Vilanova Artigas 1915/1985. São Paulo, ed. esp., 1985, p. 51.
} 
O Ginásio de Itanhaem (1959), projetado por Artigas, é o exemplo mais próximo na transição das proposições realizadas no âmbito residencial para um edifício de maior escala. A grande cobertura passa então a abrigar todas as funções educacionais, supondo o dimensionamento de um amplo espaço comum, ambiente integrado e passível de ser vivenciado como uma experiência coletiva. Desse modo, a nova estrutura arquitetônica, apoiada sobre um conjunto de pórticos seriados, permite a concepção de um espaço integrado que abandona o sentido da escola como um galpão para configurar um pátio coberto. ${ }^{35}$

Este edifício é constituído como percurso longelíneo e ininterrupto, pois desde a entrada, pontuada por um painel de cerâmica retratando Anchieta, concebido por Francisco Brennand, até os limites do prédio - espaço imaginado para ser usado em festas e atividades esportivas - está subentendida uma promenade para a re-educação do individuo: um compromisso pautado pela confiança de que a arquitetura seria capaz de lançar um outro olhar sobre a nossa história e aumentar o convívio entre as pessoas.

Esse edifício apenas foi possível devido ao impulso inicial dado pelo Instituto de Previdência do Estado de São Paulo - IPESP, já que esse órgão passou a chamar arquitetos para projetarem obras escolares. Nesse rumo, o Governador Carvalho Pinto, em um esforço de diminuir o déficit de salas de aulas em São Paulo, ratificou essa ação e o Estado tornou-se, nesse sentido, o principal agente financiador das premissas em elaboração por Artigas. A partir do Ginásio de Itanhaem, os profissionais paulistas passam a ser convidados a projetar obras públicas. ${ }^{36}$

\footnotetext{
35 ARTIGAS, V. Vilanova Artigas: arquitetos brasileiros. São Paulo, Instituto Lina Bo e P. M. Bardi / Fundação Vilanova Artigas, 1997, p. 85.

${ }^{36}$ FERREIRA, A. F. de; CORRÊA, M. E. P.; MELlO, M. G. de. (Org.). Arquitetura Escolar Paulista. São Paulo, FDE/ Imprensa Oficial do Estado, 1998, p. 32.
} 

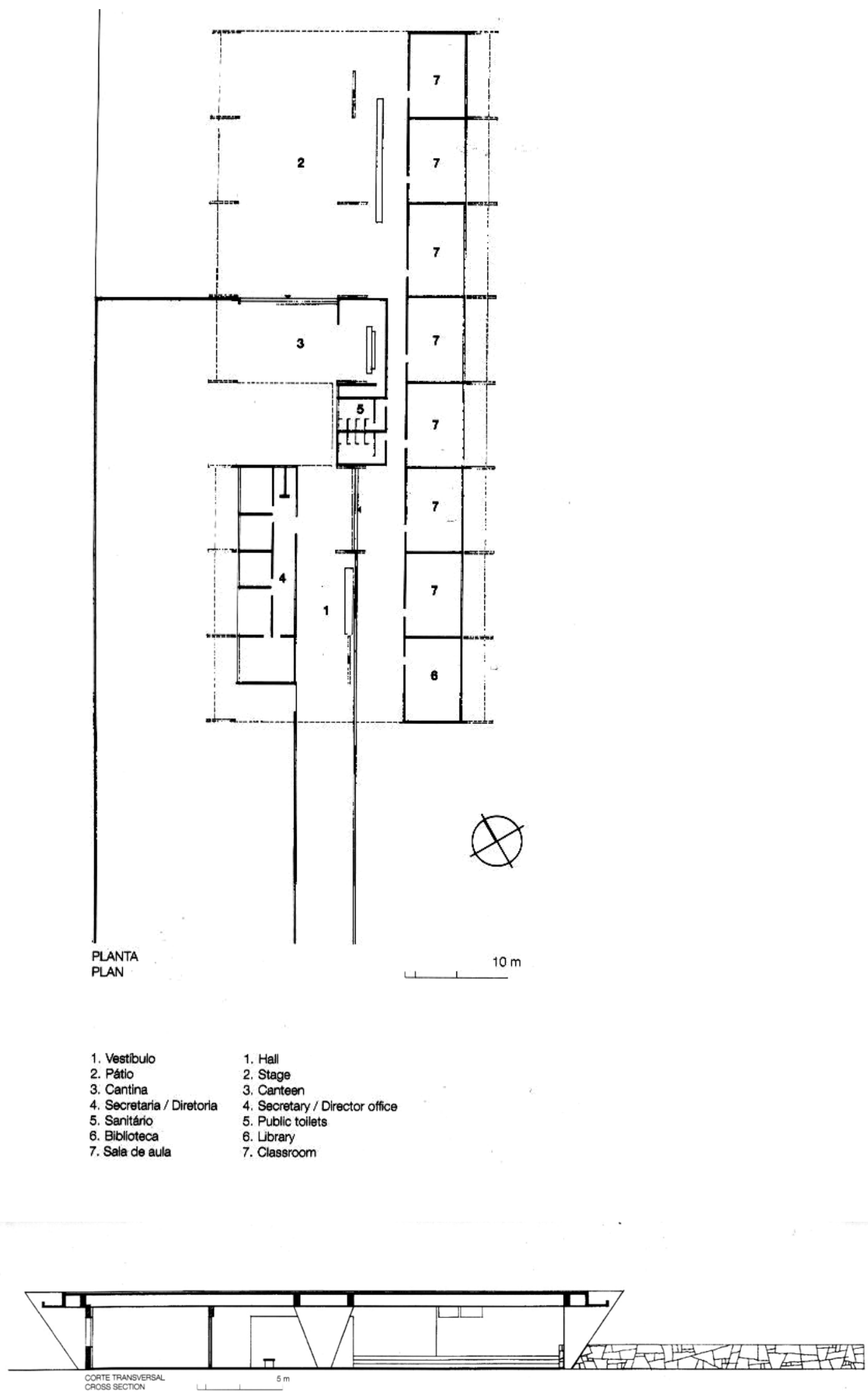

Figura 23 - Ginásio de Itanhaem, 1959, projeto. Fonte: Artigas (1997, p. 86). 


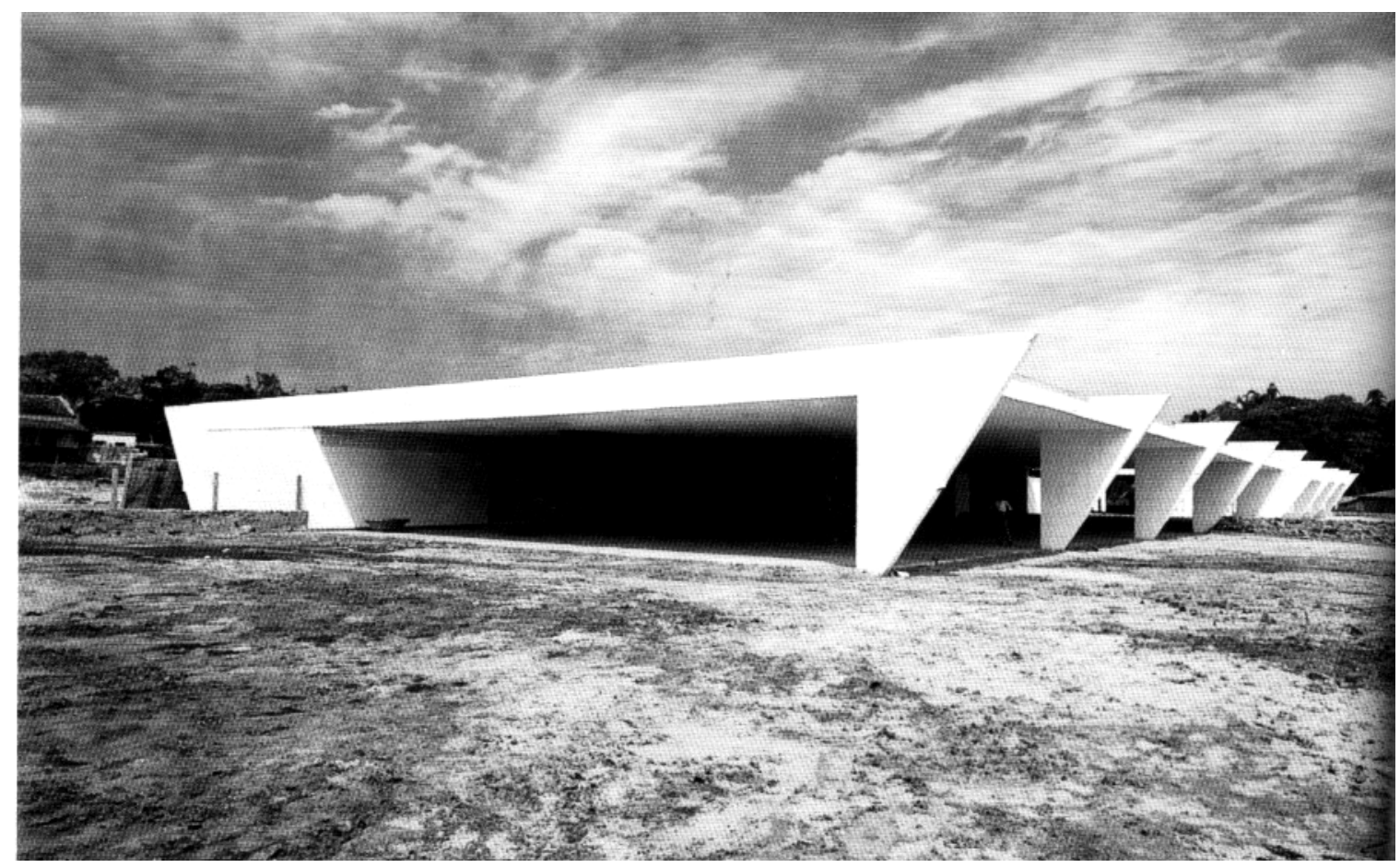

Figura 24 - Ginásio de Itanhaem, 1959, exterior. Fonte: Artigas (1997, p. 86).

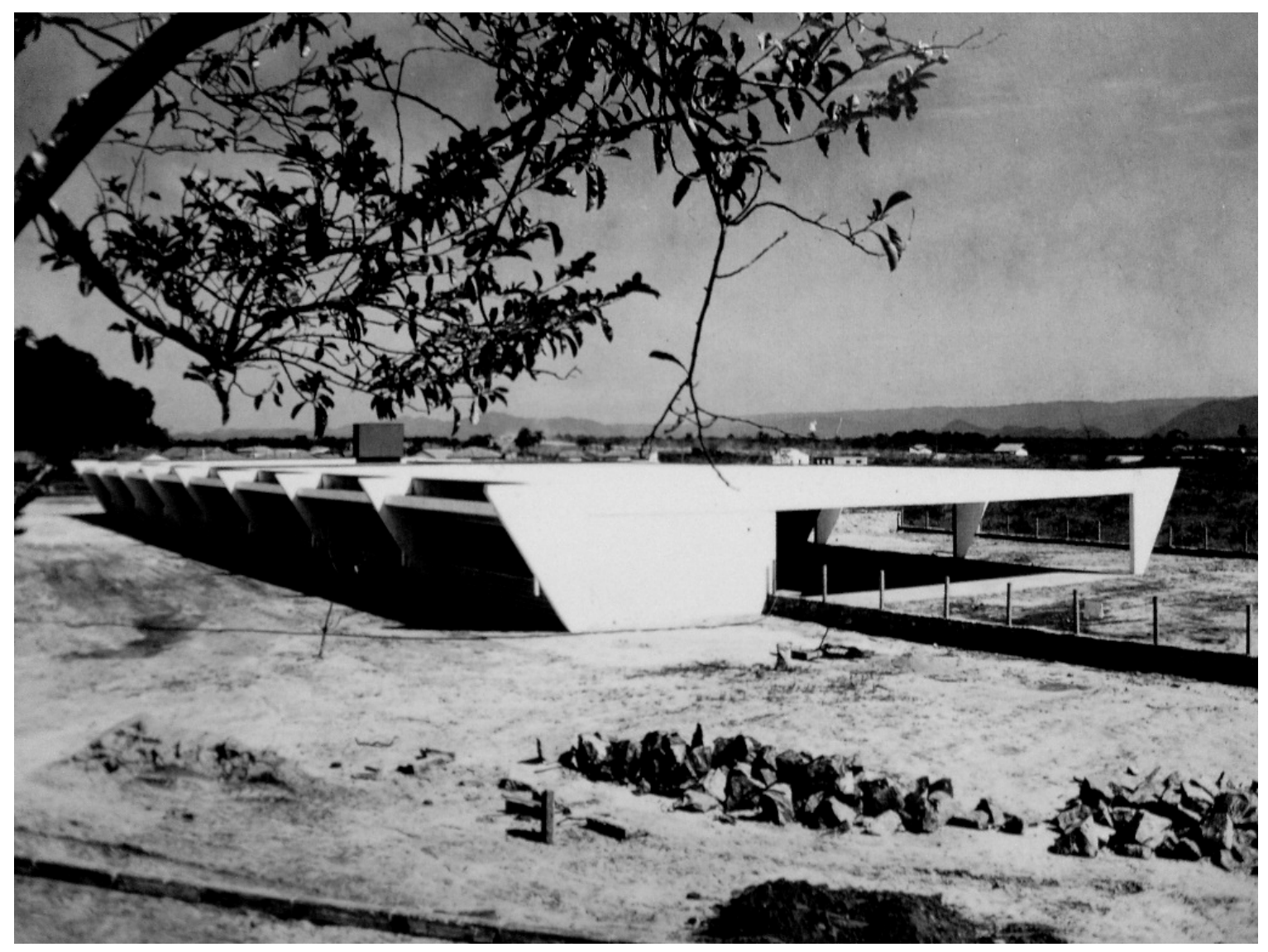

Figura 25 - Ginásio de Itanhaem, 1959, vista exterior. Fonte: Artigas (1997, p. 90). 
Além desse motivo, que faz do Ginásio de Itanhaem um experimento emblemático, a proposta do prédio projetado por Artigas promoveu uma alteração brusca no modo como eram produzidas as escolas no país, sobretudo em São Paulo: o que era uma construção "quase rural" em alvenaria e com tesouras de madeira, passou a ser um edifício com planta livre e estruturas independentes de concreto armado. Trata-se de uma construção onde a técnica desde a laje impermeabilizada até os elementos portantes - visa uma produção em larga escala. Desse modo, de acordo com Sanovicz (1988), esse ginásio, “[...] como protótipo da Arquitetura que acontece nessa época é, sem dúvida, um modelo”. 37

Sua recorrência será ratificada no Ginásio de Guarulhos (1960). No entanto, o abrigo da grande cobertura agora será resguardado por elementos vazados nas laterais que garantem conforto no trato da insolação. Logo, em virtude deste ser um prédio público, o diálogo com a cidade não seria necessariamente mantido pelo fato do edifício estar aberto, mas pelas atividades internas que fossem destinadas à comunidade. Dessa maneira, a função escolar permanece recolhida ao seu interior, enquanto a sua estrutura espacial constrói um sentido de urbanidade, em detrimento de finos acabamentos e em favor da interação social.

Assim, no Ginásio de Guarulhos, por entre as salas de aula e as demais funções do programa, surge um grande pátio interno, ambiente de visível destaque, pois recebe um grande mural do artista Mário Gruber. É nesse interior que se constituirá a noção de espaço público trabalhada por Artigas. Um vazio imaginado como lugar privilegiado de encontros que, ladeado por bancos contínuos, também permite a "imprevisibilidade do uso". 38

\footnotetext{
${ }^{37}$ SANOVICZ, A. Depoimento a J. Wolf. WOLF, J. Escola Paulista: uma pedra no caminho. $A U$, São Paulo, n. 17, p. 49-69, abr./maio 1988, p. 56.

38 Recorro aqui não necessariamente a um conceito trabalhado por Vilanova Artigas, mas à noção de "projeto inconcluso" proposta por Lucrécia D'Aléssio Ferrara. Pretendemos com isso, fazer entender o Ginásio de Guarulhos como "[...] projeto que se redesenha dentro da própria transformação do desenho urbano". Cf. FERRARA, L. D. Redesenho de uma idéia. Cadernos de Arquitetura, Bauru, São Paulo, n. 01, p. 05-12, jan./jun. 1996, p. 12. Contudo, é preciso salientar que, muitas vezes, o pátio vazio presente em algumas obras de Artigas permanece vago, desocupado, abandonado.
} 
1. Sala de aula

2. Auditório

3. Biblioteca

4. Pátio central

5. Secretaria / Diretoria

6. Cantina / Acesso

7. Jardim

1. Classroom

2. Auditorium

3. Library

4. Court

5. Secretary / Director

6. Cafiteen / Entrance

7. Garden
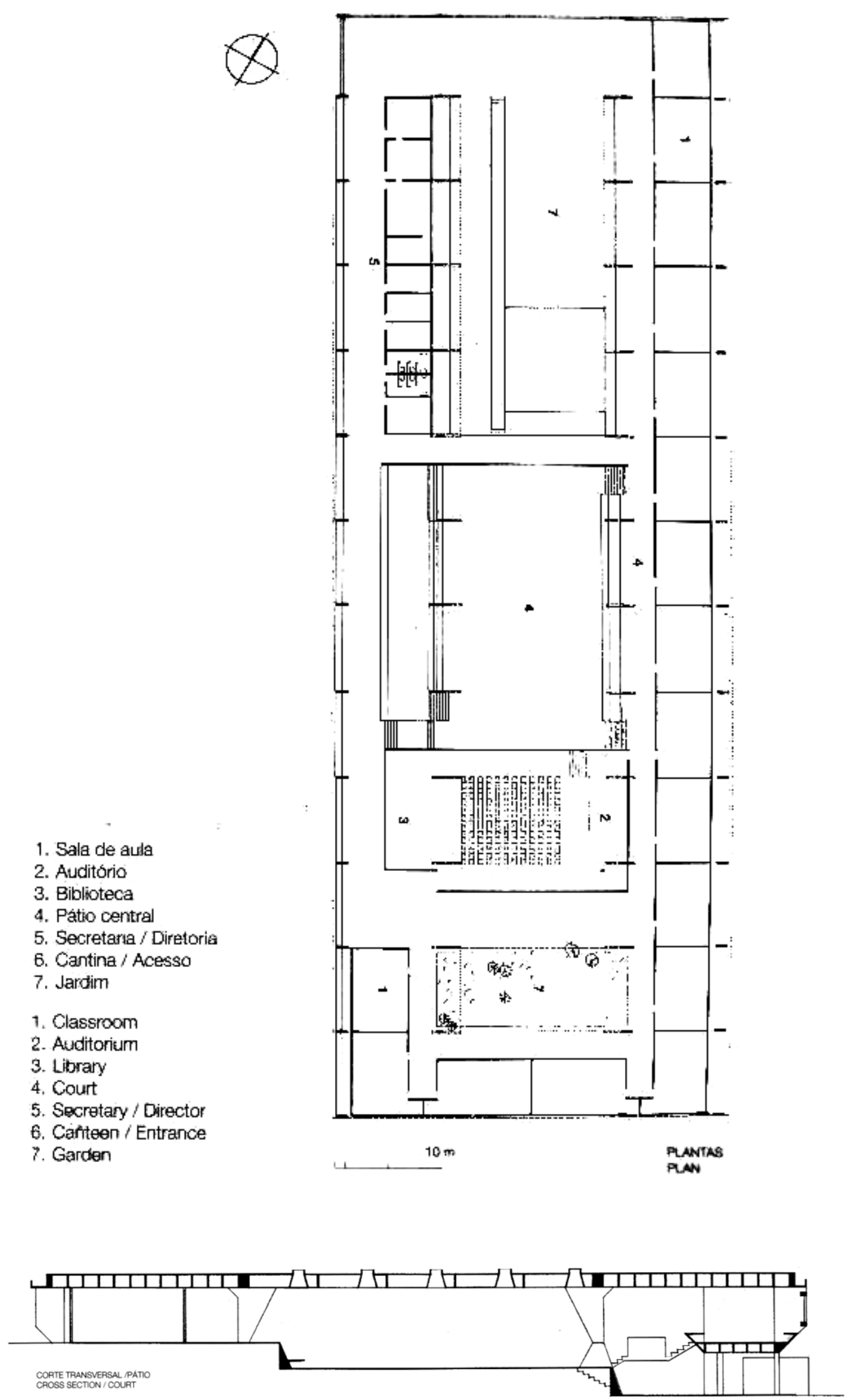

Figura 26 - Ginásio de Guarulhos, 1960, projeto. Fonte: Artigas (1997, p. 89, 91). 


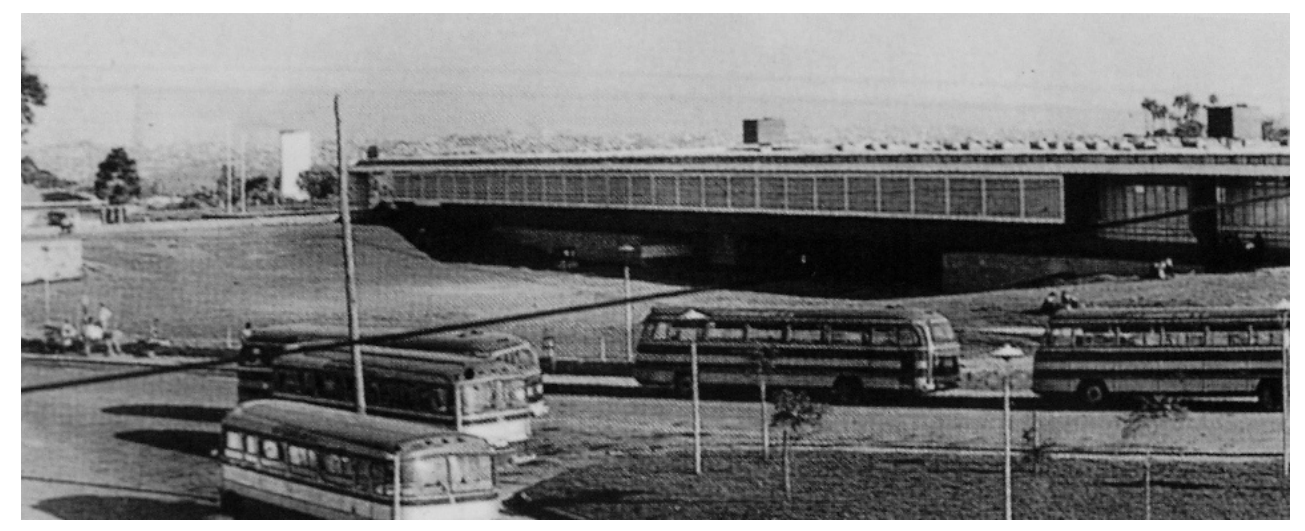

Figura 27 - Ginásio de Guarulhos, 1960, exterior. Fonte: Artigas (1997, p. 88).

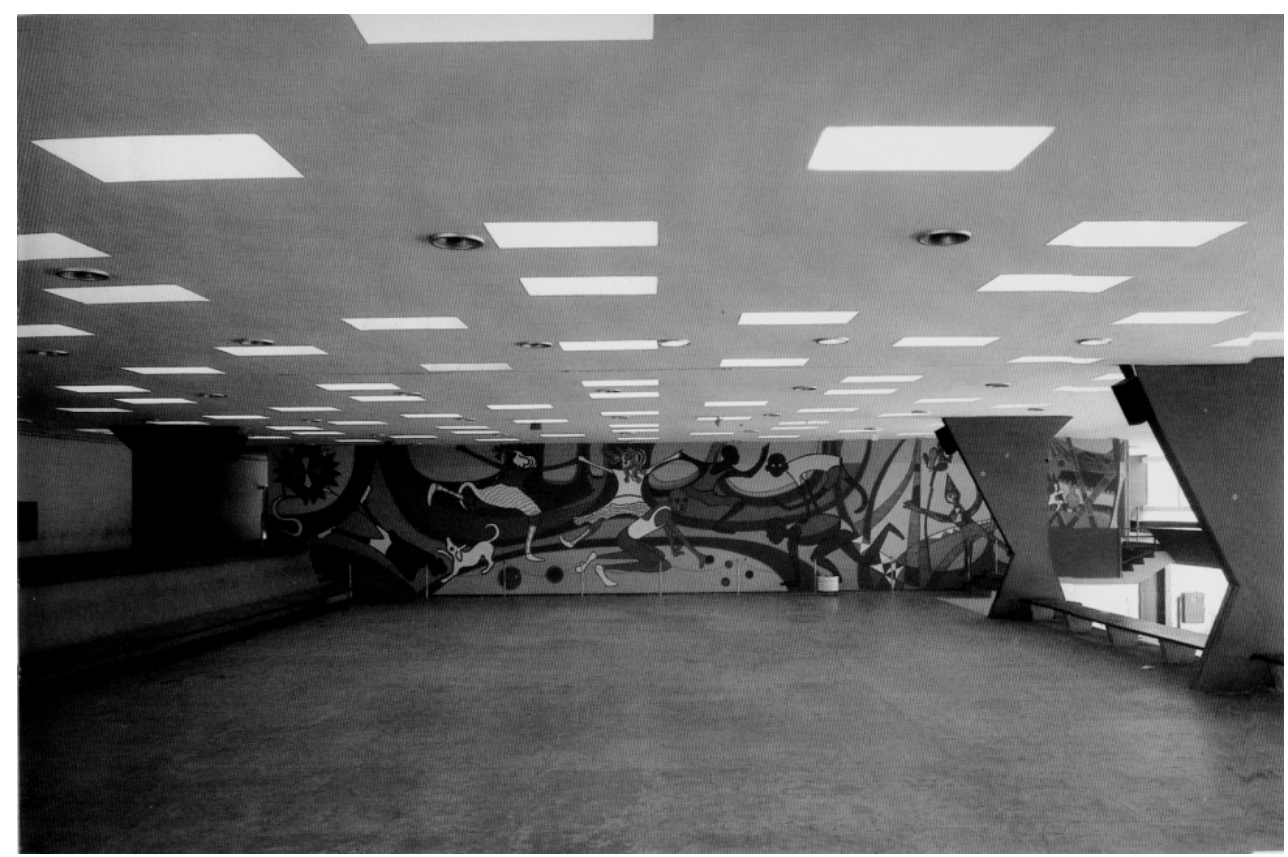

Figura 28 - Ginásio de Guarulhos, 1960, interior. Fonte: Ferreira; Corrêa; Mello; (1998, p. 221).

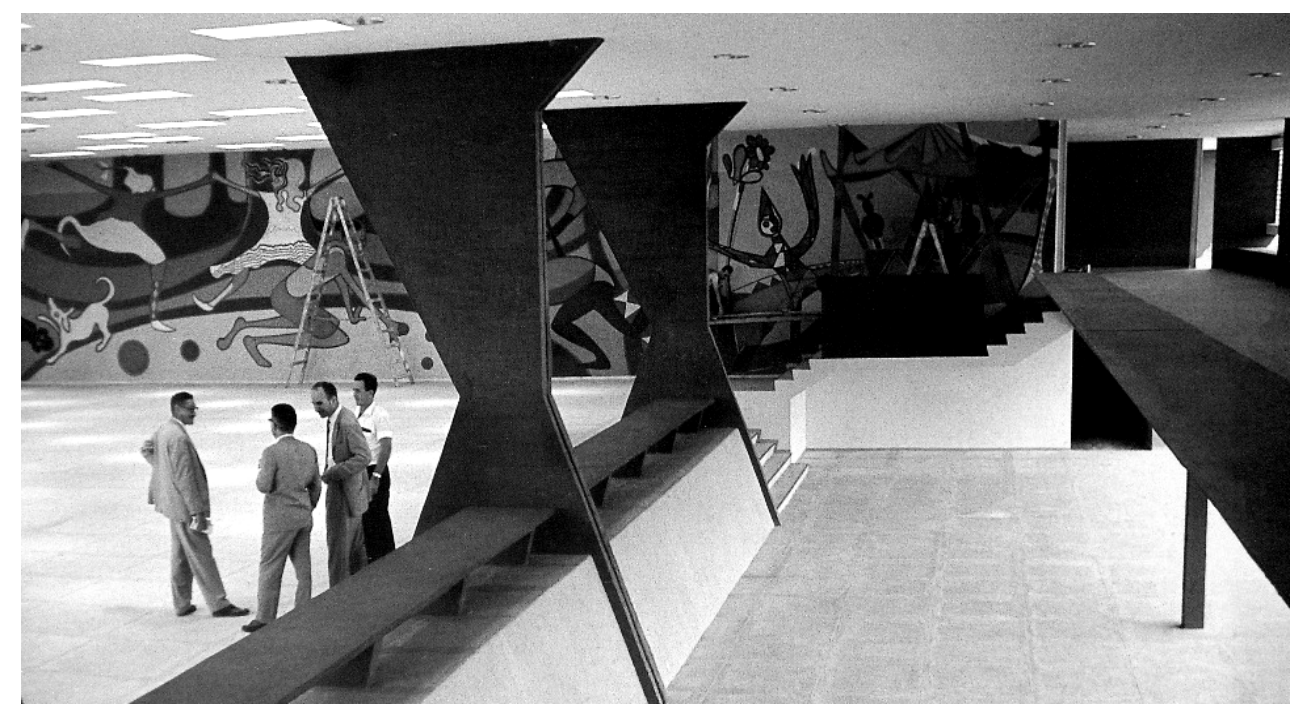

Figura 29 - Ginásio de Guarulhos, 1960, detalhe interior. Fonte: Artigas (1997, p. 91). 
Entretanto, esse amplo recinto destinado à coletividade demandará, também, uma nova solução para a entrada de luz. Artigas confere ao amplo salão, um dispositivo característico indispensável que se transformará em uma marca de todas as suas construções daí por diante: a iluminação filtrada por aberturas feitas na cobertura. A saída construtiva da iluminação zenital pôde reconstituir a atmosfera exterior, mesmo no interior do edifício. ${ }^{39}$

De alguma forma, essa solução contribuirá também para que o espaço adquira certo ar de ambivalência, pois, no pátio interno, são acentuados os contrastes entre luz e sombra, cheios e vazios, dentro e fora. Logo, é possível pressupor que, externamente, o Ginásio de Guarulhos se configure como uma enorme massa, cujo pouso se faz leve pelo dimensionamento dos pórticos, enquanto, internamente, o peso da grande cobertura se dilui entre os orifícios luminosos que pontuam a laje, possibilitando uma sensação de um ambiente em constante flutuação.

Será sob esses contrastes, dimensionados pelas possibilidades da técnica, que os projetos de Artigas procurarão deflagrar a dubiedade entre o interior-exterior, buscando demonstrar os impasses da arquitetura em face da realidade. Se, de algum modo, os seus edifícios continuam a rechaçar a cidade, no seu interior, eles mantêm as relações sociais idealizadas. São lugares em que a continuidade do espaço tem, como pano de fundo, a linha do horizonte tangenciada a partir do âmago da grande cobertura. Sob as empenas de concreto armado das escolas que Artigas projetou, se encerram exemplos da busca de uma sociabilidade que poderia servir de base para formação dos jovens e a configuração de uma sociedade mais justa.

A partir dessa proposição, o prédio da Faculdade de Arquitetura e Urbanismo da Universidade de São Paulo - FAU/USP (1961) constrói o espaço onde melhor se expressam

\footnotetext{
39 ARTIGAS, V. Vilanova Artigas: arquitetos brasileiros. São Paulo, Instituto Lina Bo e P. M. Bardi / Fundação Vilanova Artigas, 1997, p. 88.
} 
os ideais de Artigas. Esta obra surge como um paradigma da democracia, tal como podemos observar nos trechos abaixo:

[...] O prédio da FAU, como proposta arquitetônica, defende a tese da continuidade espacial. Seus seis pavimentos são ligados por rampas suaves e amplas, em desníveis que procuram dar a sensação de um só plano. [...] O espaço é aberto e as divisões e os andares praticamente não o secionam [...].

[...] A sensação de generosidade espacial que sua estrutura permite, aumenta o grau de convivência, de encontros, de comunicação. Quem der um grito dentro do prédio, sentirá a responsabilidade de haver interferido em todo o ambiente. Aí o indivíduo se instrui, se urbaniza, ganha espírito de equipe. [...]

[...] Este prédio acrisola os santos ideais de então: pensei-o como a espacialização da democracia, em espaços dignos, sem portas de entrada, porque o queria como um templo, onde todas as atividades são lícitas. ${ }^{40}$

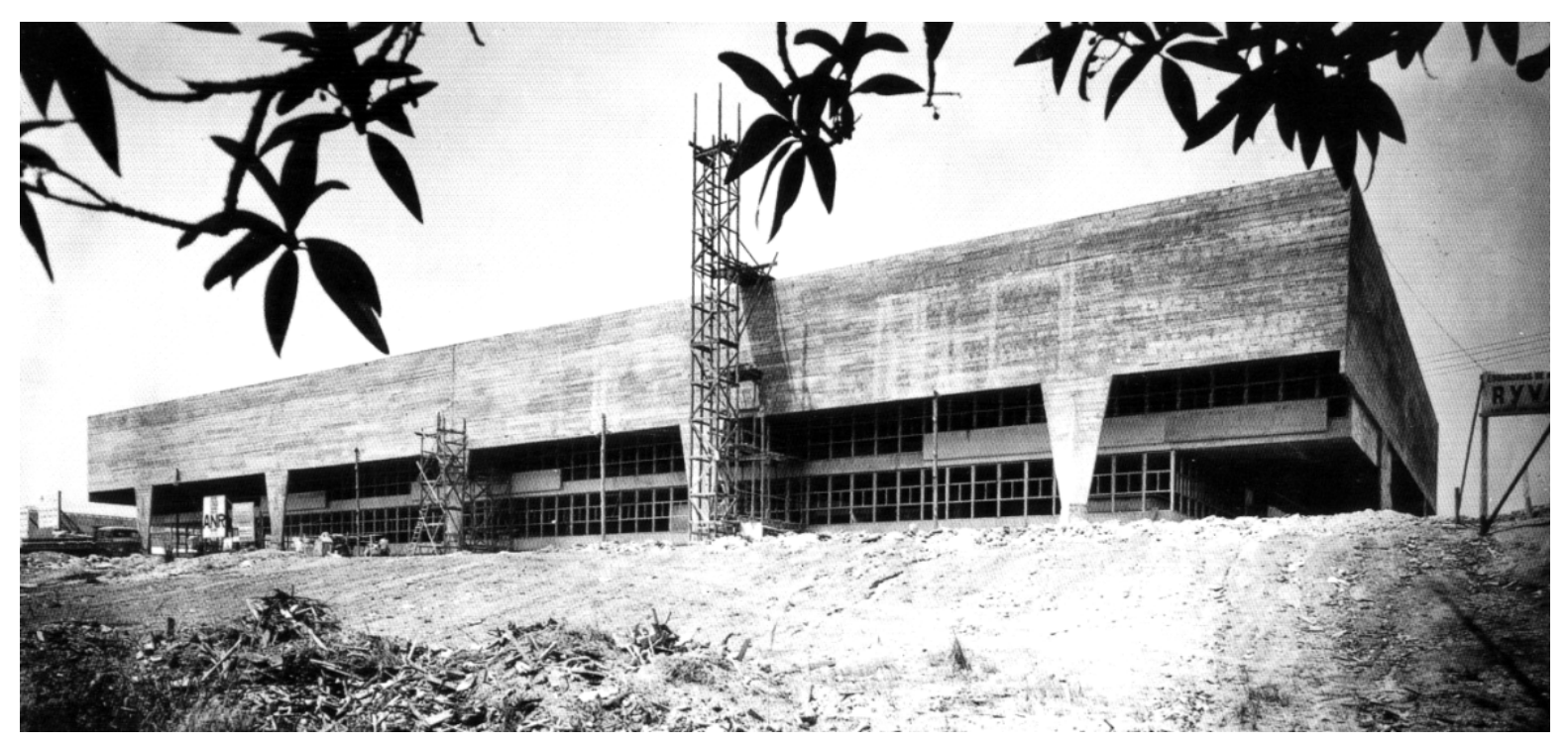

Figura 30 - Faculdade de Arquitetura e Urbanismo da Universidade de São Paulo, 1961, construção. Fonte: Artigas (1997, p. 101).

\footnotetext{
${ }^{40}$ ARTIGAS, V. Vilanova Artigas: arquitetos brasileiros. São Paulo, Instituto Lina Bo e P. M. Bardi / Fundação Vilanova Artigas, 1997, p. 101.
} 


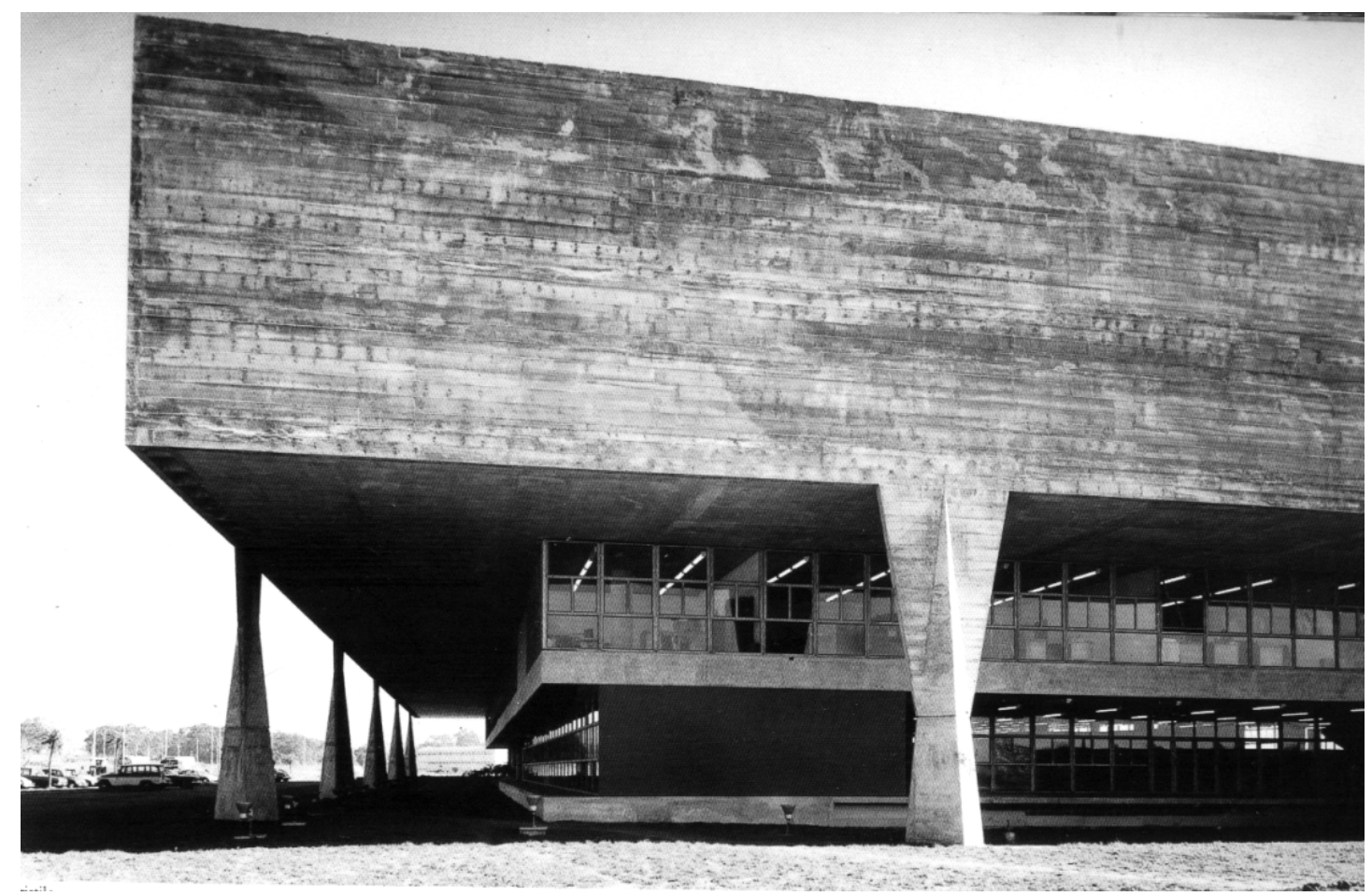

Figura 31 - Faculdade de Arquitetura e Urbanismo da Universidade de São Paulo, 1961, exterior. Fonte: Artigas (1997, p. 107).

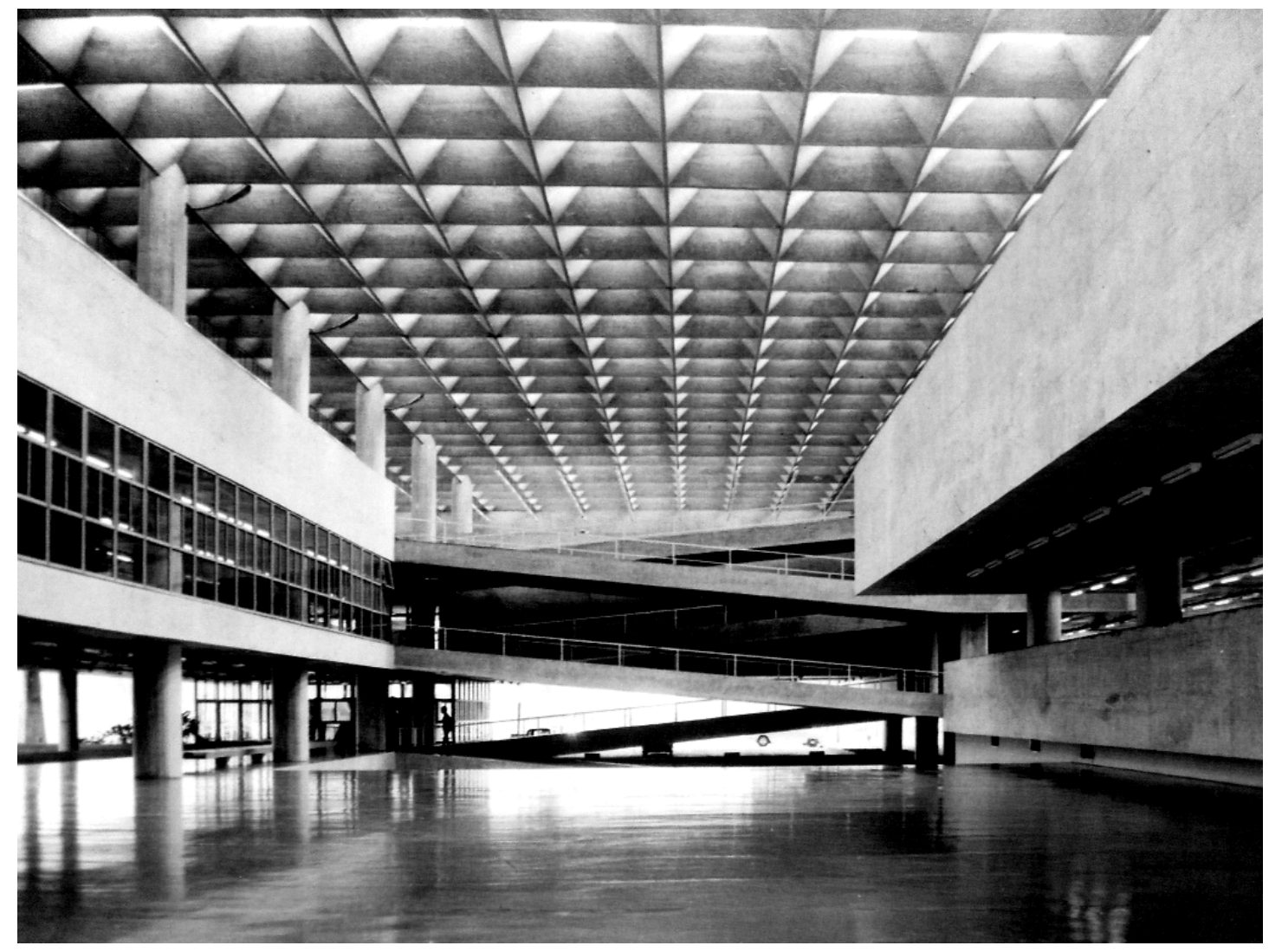

Figura 32 - Faculdade de Arquitetura e Urbanismo da Universidade de São Paulo, 1961, interior. Fonte: Artigas (1997, p. 109). 
Desses pressupostos, emanam um espaço contínuo, uma pedagogia e as relações sociais requeridas e conseguidas pela técnica. A conjugação das idéias socialistas em uma arquitetura que esperava ser capaz de formar profissionais conscientes do seu papel na constituição de um projeto coletivo e, assim, contribuir para o progresso do país, por meio da industrialização da construção. Esta proposição ansiava por dar cabo da resolução de desenhos que iam desde objetos produzidos em série até a escala da cidade - em uma relação análoga ao projeto da Bauhaus no pós-guerra.

Nesse caso, enquanto o prédio da FAU/USP se constitui, externamente, como uma caixa de concreto, o seu interior, iluminado pelas aberturas zenitais que se conformam por entre a grelha da grande laje nervurada, pode ser lido como metáfora de um templo de luz; um lugar de onde se propagariam os ideais de progresso econômico e social. É, nesse sentido, que a logomarca da FAU/USP, criada por Cauduro Martino, nos dá pistas sobre a carga utópica condensada nesse espaço interno, articulado como um farol que pode, talvez, ter paralelo com a xilogravura da catedral de cristal, de Lyonel Feininger, que ilustra o manifesto da Bauhaus de 1919, escrito por Walter Gropius. ${ }^{41}$
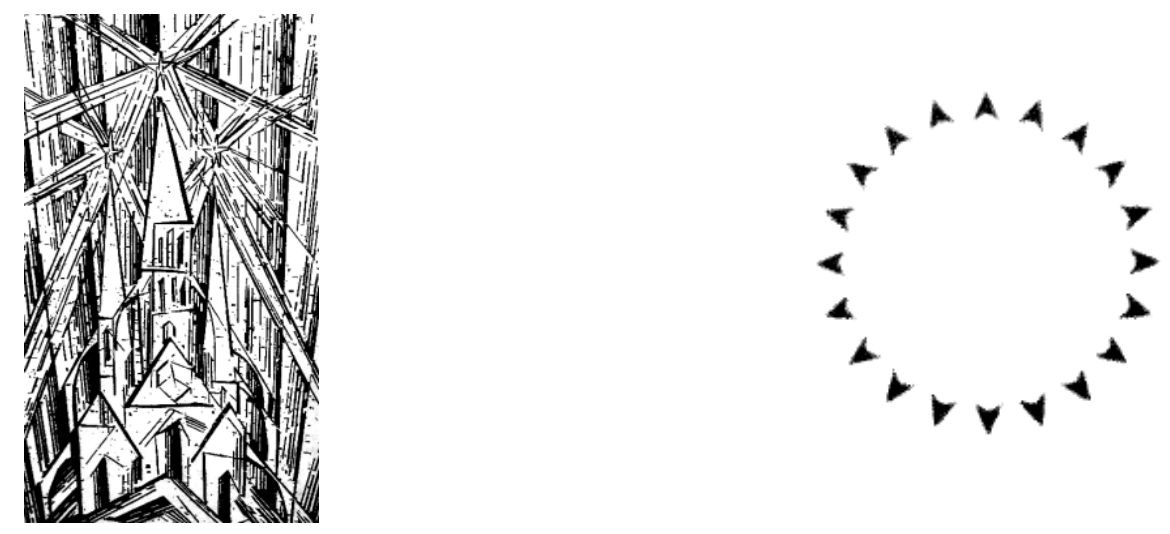

Figura 33 e 34 - Xilogravura, Feininger, 1919; Logomarca da FAU/USP, Martino, 1961. Fonte: Droste (1994, p. 18); Melo (2006, p. 236).

\footnotetext{
${ }^{41}$ Além dessa possibilidade, o desenho de um sol criado por Martino para a FAU/USP, se remete à célebre frase de Le Corbusier: "L'architecture est le jeu, savant, correct et magnifique des volumes assemblés sous la lumière” e à secção de uma coluna grega. Cf. MELO, C. H. de. O design gráfico brasileiro: anos 60. São Paulo, Cosac Naify, 2006, p. 236.
} 
Contudo, o que no início do século podia ser lido como drama do artesanato em face à mecanização dos meios de produção, na realidade brasileira, se revelava como os entraves para a superação de um país cheio de contradições. Assim, a constituição da permeabilidade desse espaço translúcido, bem como o currículo da escola, englobando a história, a tecnologia e o projeto, era um modo de preparação para a nova coletividade, cujo incremento da industrialização poderia fazer sobrepujar todo o grau de arcaísmo ainda presente no Brasil. Porém, esses contra-sensos não eram tão simplesmente postos de lado em favor de uma ordem imaginada, circunscrita ao prédio da FAU/USP, mas deflagrados na sua própria estrutura de concreto armado.

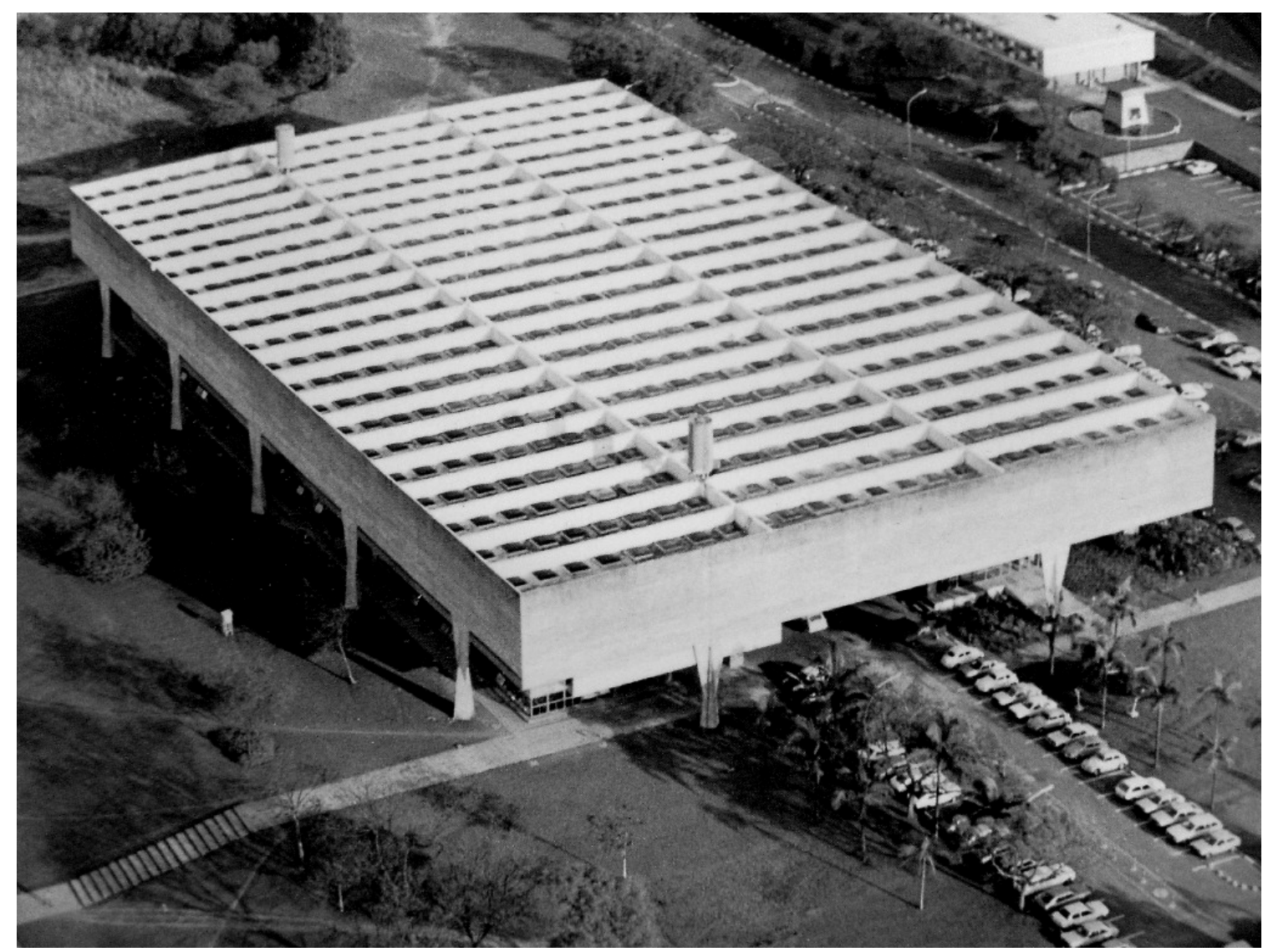

Figura 35 - Faculdade de Arquitetura e Urbanismo da Universidade de São Paulo, 1961, vista aérea. Fonte: Artigas (1997, p. 106).

A transição do prédio para o terreno se constrói como contraposição latente entre um modelo ideal de civilização - possibilitado pelo interior da FAU/USP - e a esperança de 
alteração das mazelas do quadro urbano. Assim, não se pode supor, nas posições de Artigas, uma postulação democrática dessa arquitetura acontecendo de maneira pacífica. Os pilares triangulares da FAU/USP que sustentam o volume edificado não cumprem apenas o papel de "fazer cantar o ponto de apoio", como dizia Artigas, mas também atestam uma relação conflituosa entre denúncia e promessa. Nesse caso, o partido do projeto e a sua estrutura tencionam o enfrentamento dos problemas que impedem uma franca articulação do espaço público.

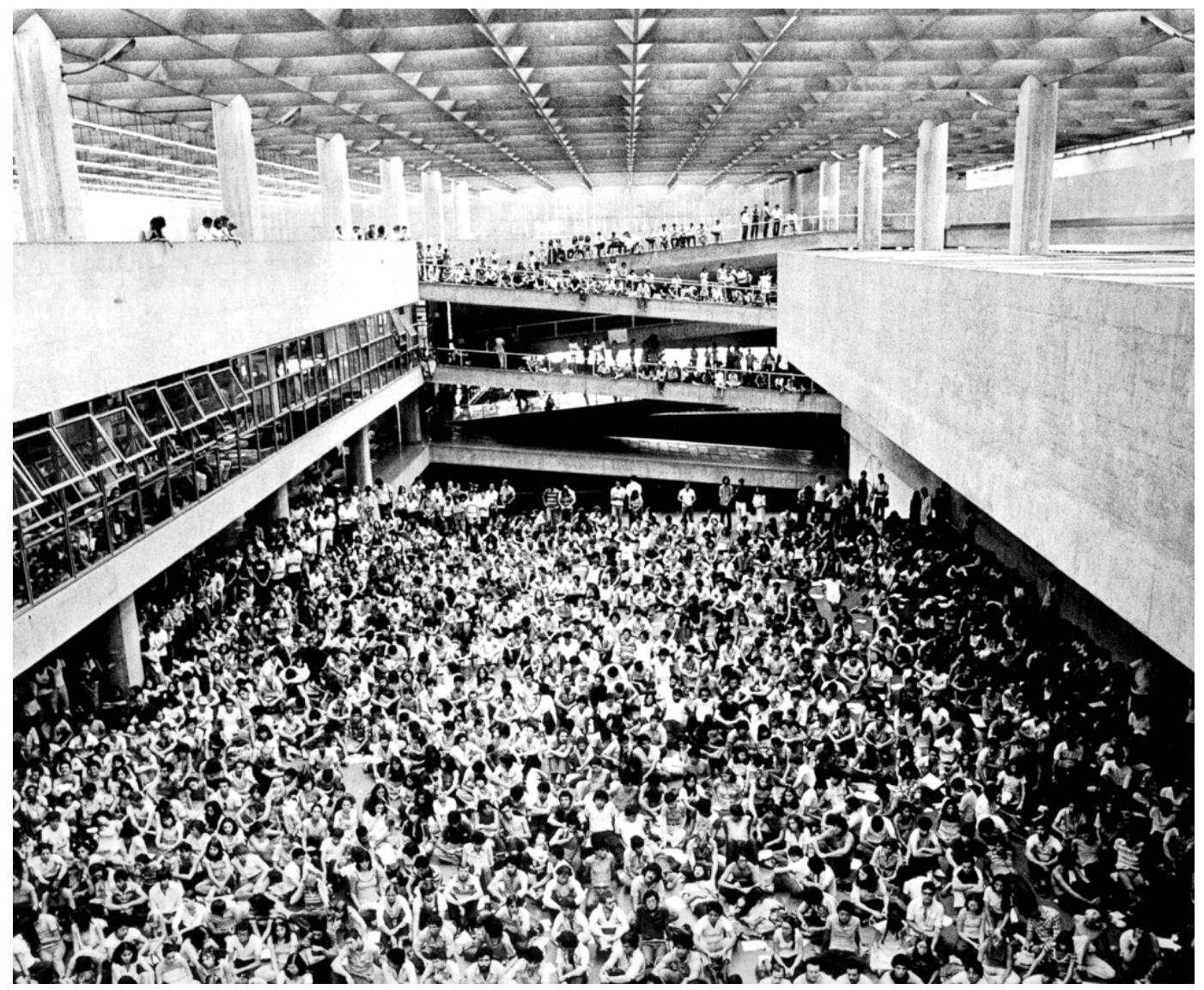

Figura 36 - Faculdade de Arquitetura e Urbanismo da Universidade de São Paulo, 1961, Salão Caramelo. Fonte: Artigas (1997, p. 113). 


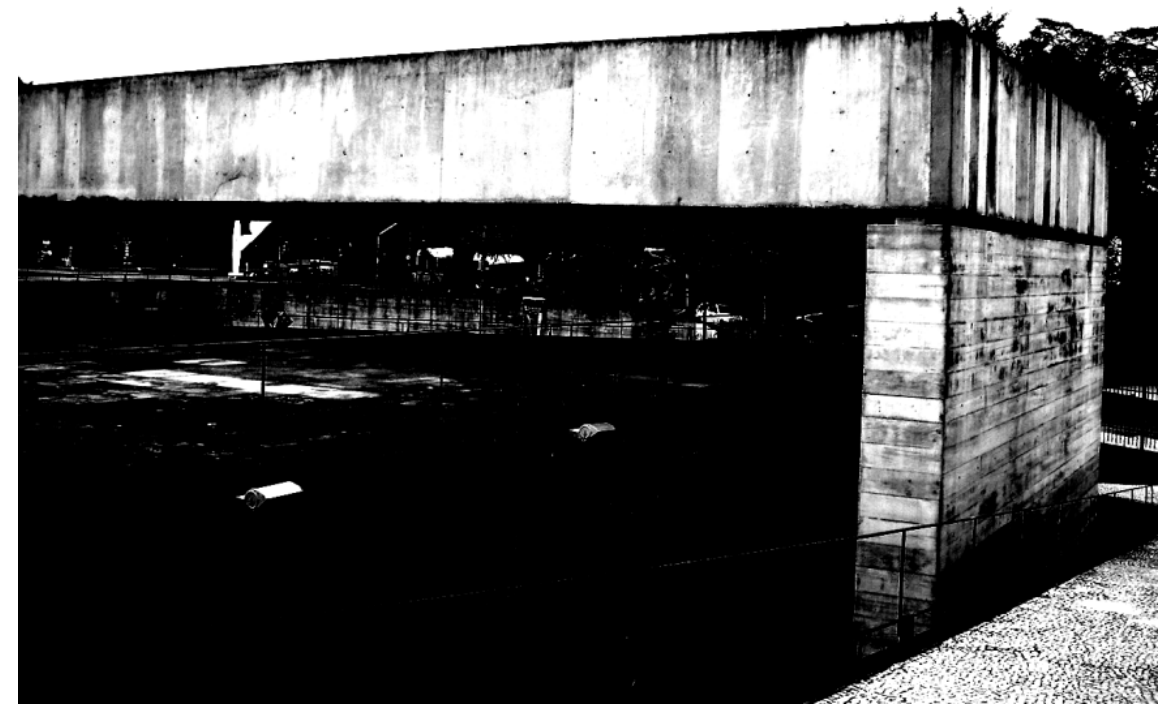

2. O ENCASTELAMENTO ESTÉTICO E POLÍTICO DA ARQUITETURA 


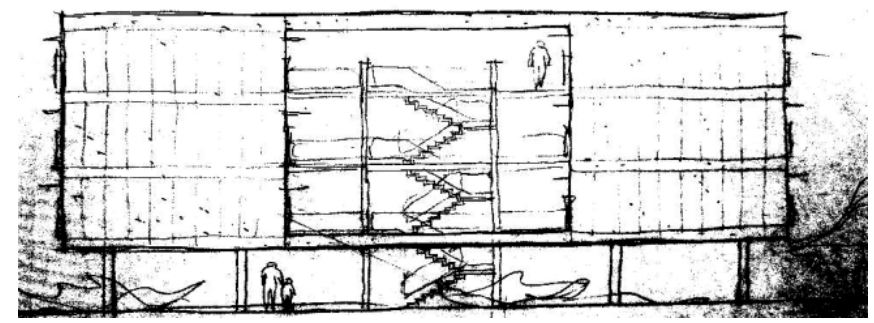

2.1. O avesso das idéias 
Os projetos residenciais realizados por Artigas tinham como preconização, ser uma espécie de laboratório de testes para a construção de edifícios em uma outra escala: a da cidade. Nesse sentido, nos anos 60, o esforço de constituição da grande cobertura como solução aplicável rendeu edificações emblemáticas, sobretudo, as destinadas aos programas escolares. No entanto, será a partir da casa Ivo Viterito (1962-64) que se consolidará um "padrão para a elaboração de uma série de casas". ${ }^{42}$

Nessa residência, o conjunto arquitetônico se adapta aos recuos do lote exíguo e configura uma elevação frontal sem aberturas, reforçando um caráter de edificação que se volta para dentro, enquanto o seu sistema estrutural colabora para uma racionalidade ainda maior. Dessa maneira, o projeto é dotado de apenas quatro apoios ajustados à topografia patamarizada e quatro colunas guarnecidas por juntas de neoprene, que se interligam às duas grandes empenas laterais, amparando a laje nervurada e protegendo-a dos esforços horizontais.

Trata-se de uma composição que acaba por se moldar como um "edifício genérico", uma vez que concebe o espaço utilizando apenas seus elementos constitutivos - fundações, pilares, vigas e a cobertura em concreto armado. É uma solução que se define, do ponto de vista de uma moradia, como uma penosa prova de despojamento e, ao mesmo tempo, como uma resposta possível de ser estendida para quaisquer programas. Esta condição faz da casa Ivo Viterito um "modelo da fábrica, da escola, da agencia bancária ou de qualquer outro abrigo". 43

\footnotetext{
42 ARTIGAS, V. Vilanova Artigas: arquitetos brasileiros. São Paulo, Instituto Lina Bo e P. M. Bardi / Fundação Vilanova Artigas, 1997, p. 122.

${ }^{43}$ ACAYABA, M. M. Residências em São Paulo 1947-1975. São Paulo, Projeto, 1986, p. 17.
} 

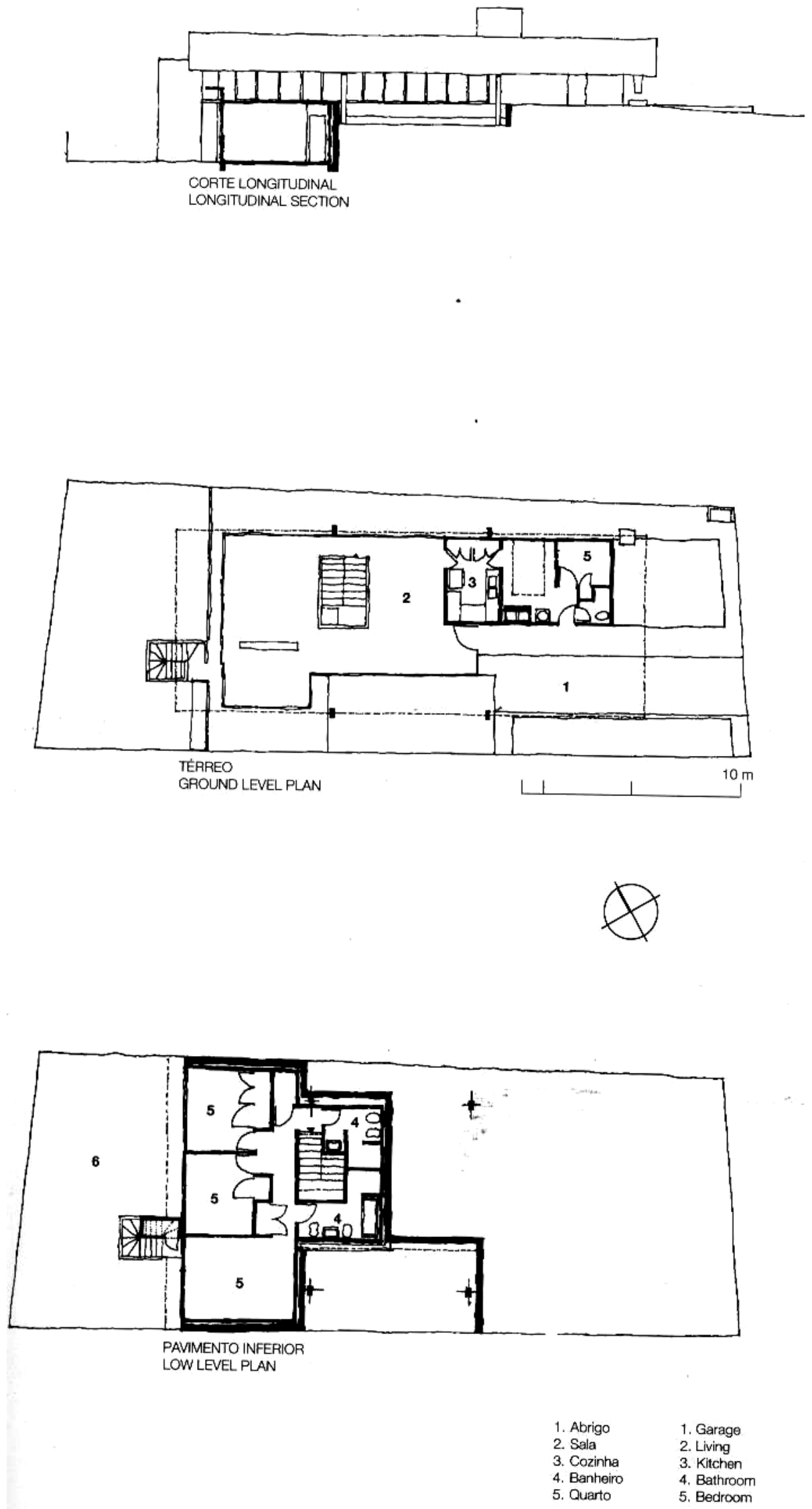

Figura 37 - Casa Ivo Viterito, 1962, projeto. Fonte: Artigas (1997, p. 123). 


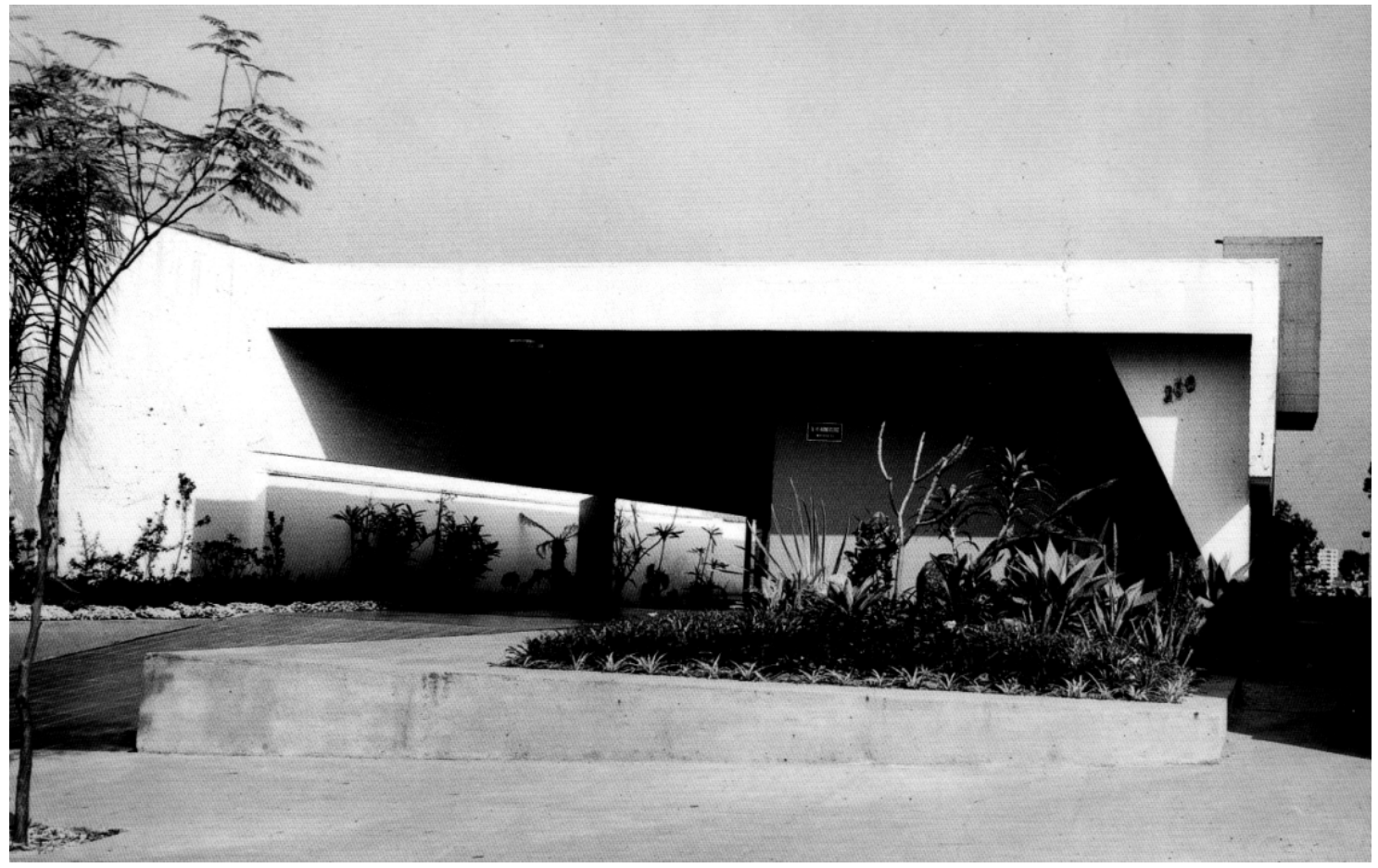

Figura 38 - Casa Ivo Viterito, 1962, exterior, frente. Fonte: Artigas (1997, p. 122).

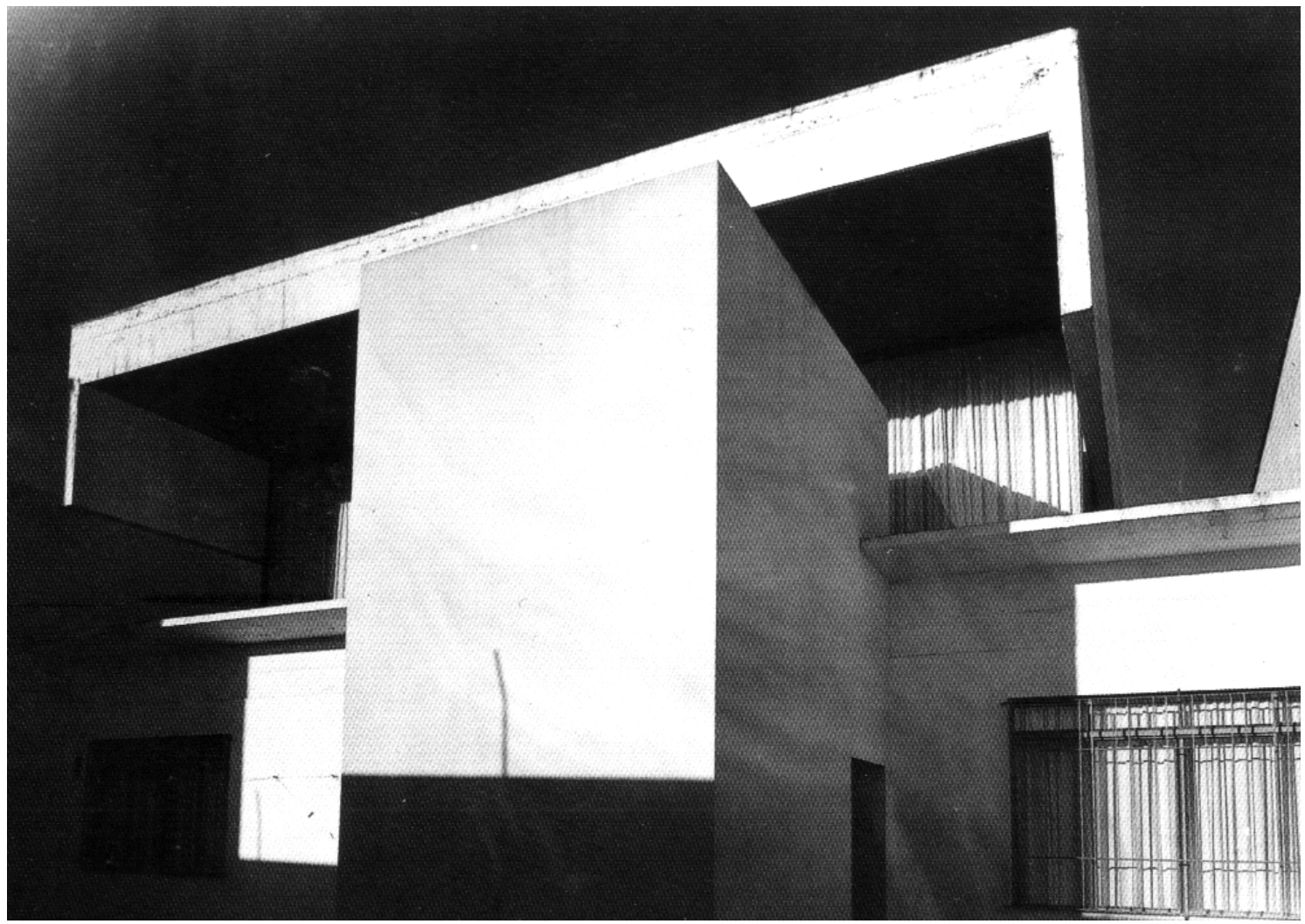

Figura 39 - Casa Ivo Viterito, 1962, exterior, fundos. Fonte: Artigas (1997, p. 124). 
Porém, as implicações dessa disseminação serão as mais incoerentes, na medida em que a idéia de Artigas para a constituição de um tipo estrutural implicava em um sistema construtivo passível de economizar meios e, assim, concorrer para uma reordenação dos bairros da capital paulista. No entanto, a técnica do concreto armado pôde facilitar uma aplicação indiscriminada do "padrão", aumentando o desequilíbrio urbano e acelerando a especulação do solo, pois convinha com a consecução dos prédios destinados às classes abastadas e, apesar das experiências realizadas por diversos arquitetos paulistas, tornourse conveniente aos interesses do próprio mercado.

Nesse caso, o que servia como espacialização racional, numa visão integradora da construção - a aglutinação da caixa d' água à composição arquitetônica pode ser um bom exemplo desse intento -, tende a consolidar um paradigma dissociado dos pressupostos políticos de uma edificação precisa e austera. Ao avesso das idéias que previam a eliminação dos antigos ranços frequentemente associados à burguesia, as "formas nuas" projetadas por Artigas iriam, aos poucos, se transformar em uma fôrma corrente de concreto armado, signos de "modernidade", mas incapazes de contribuir para uma revolução democrática.

O fato é que depois de 1964, a veracidade das teses socialistas de Artigas em meio às casas burguesas se tornará insustentável. Com a ditadura militar, Artigas é preso e se exila no Uruguai. Nesse momento, é posta em xeque a intenção de libertação nacional que traria os avanços sociais requeridos para o Brasil, sendo revelado o fundo falso que lastreava os ideais revolucionários, uma vez que estavam entrelaçados às mesmas ambições que moviam os impulsos renovadores da burguesia nacional progressista.

Entretanto, o caráter emancipatório presente nas estruturas de concreto armado não cairá por terra somente por ter sido gestado no seio burguês e aí se sagrado como o seu emblema, mas porque a própria viabilidade de uma tipologia industrializável para a 
consecução de edificações em larga escala não era também possível devido às condições técnicas, às formas dominantes de produção e financiamento da arquitetura, à situação do canteiro de obras e às suas relações de trabalho, dentre outros fatores, esboçados até o momento. Além de caminhar lado a lado com o projeto desenvolvimentista, a promessa de racionalidade encontrava entraves de toda a ordem, que impediam a concretude de um método seriado capaz de ser utilizado na construção civil. ${ }^{44}$

Então, já não se tratava da castração do projeto coletivo pelo recrudescimento do regime político - mesmo porque o contato direto com as massas sequer havia sido tentado por Artigas -, mas de uma impossibilidade da efetiva aplicação da arquitetura moderna brasileira à industrialização da construção, diante dos impasses e desacertos sempre presentes nessa empreitada. É também por esse fato que as suas "formas" continuarão a fazer parte de um repertório burguês, em uma prática arquitetônica cada vez mais distanciada de proposições capazes de dar soluções aos problemas da casa popular, afiançando, então, a ininterrupção dos embaraços do capitalismo e o contrato legitimado com as elites brasileiras.

Contudo, mesmo diante das contradições da realidade do país, algumas tentativas de estandardização permaneceram por parte dos arquitetos paulistas. Sem poderem ultrapassar os exercícios projetivos, estas obras funcionam mais como experimentações. Esta leitura pode ser aplicada ao caso da residência Butantã (1964), elaborada por Paulo Mendes da Rocha para si e a sua família, na medida em que a sua estrutura foi "estritamente modulada", buscando

\footnotetext{
44 O Ginásio de Utinga (1962-66), em Santo André, foi um dos primeiros projetos elaborados por Artigas tendo como preocupação a utilização de estruturas pré-moldadas em concreto protendido. Ao final, devido à impossibilidade de sua execução, a obra acabou sendo construída com sistemas tradicionais. Cf. ARTIGAS, V. Vilanova Artigas: arquitetos brasileiros. São Paulo, Instituto Lina Bo e P. M. Bardi / Fundação Vilanova Artigas, 1997, p. 114-117.
} 
"uma visão de pré-fabricação", apesar das suas peças terem sido moldadas in loco e o arquiteto saber se tratar de uma proposta inviável sob o ângulo da produção industrializada. ${ }^{45}$
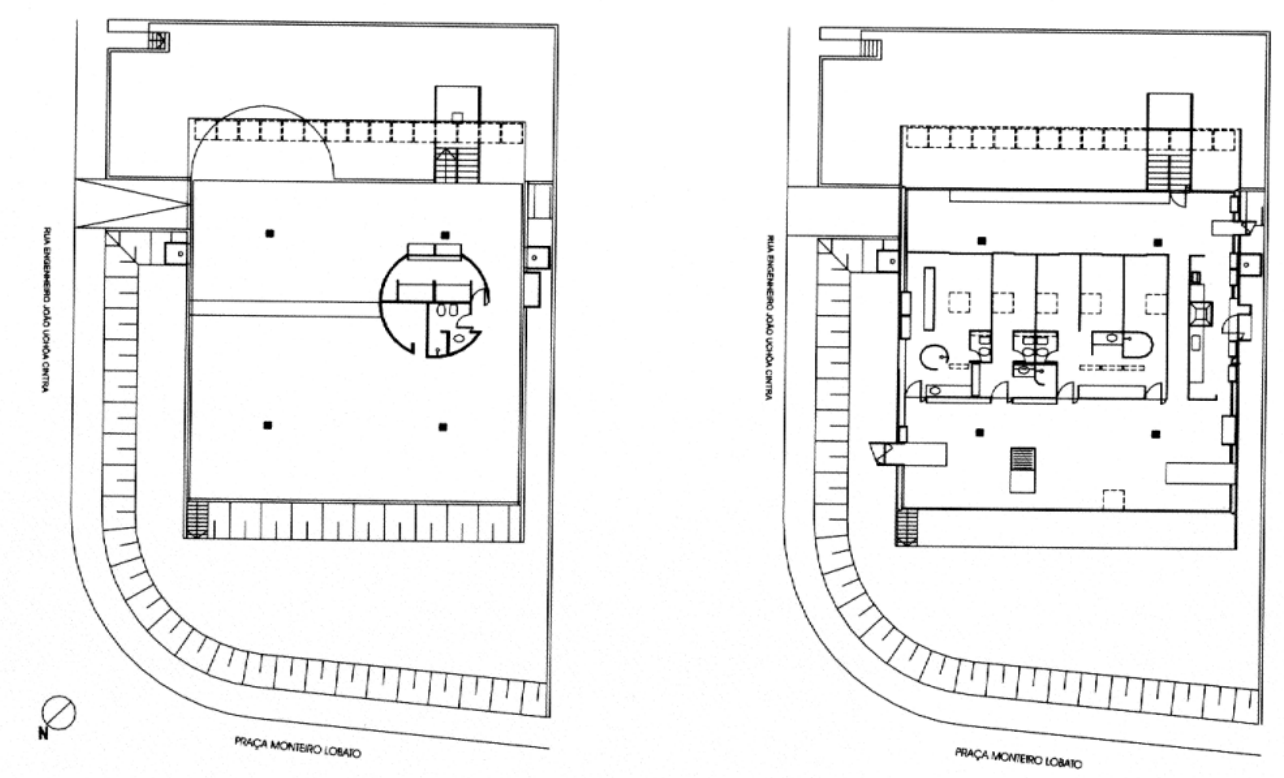

plantas do térreo e primeiro andar

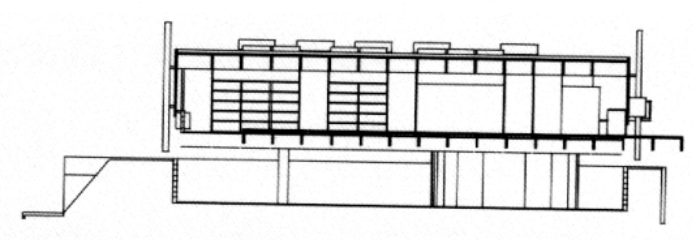

corte transversal

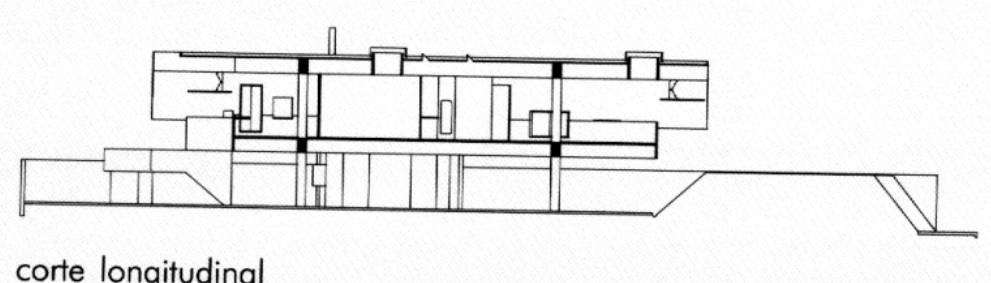

Figura 40 - Residência Butantã, 1964, projeto. Fonte: Piñón (2002, p. 48; 50).

\footnotetext{
${ }^{45}$ ROCHA, P. M. da. Cultura e Natureza. Residência Butantã. In: PIÑÓN, H. Paulo Mendes da Rocha. São Paulo, Romano Guerra, 2002, p. 24.
} 


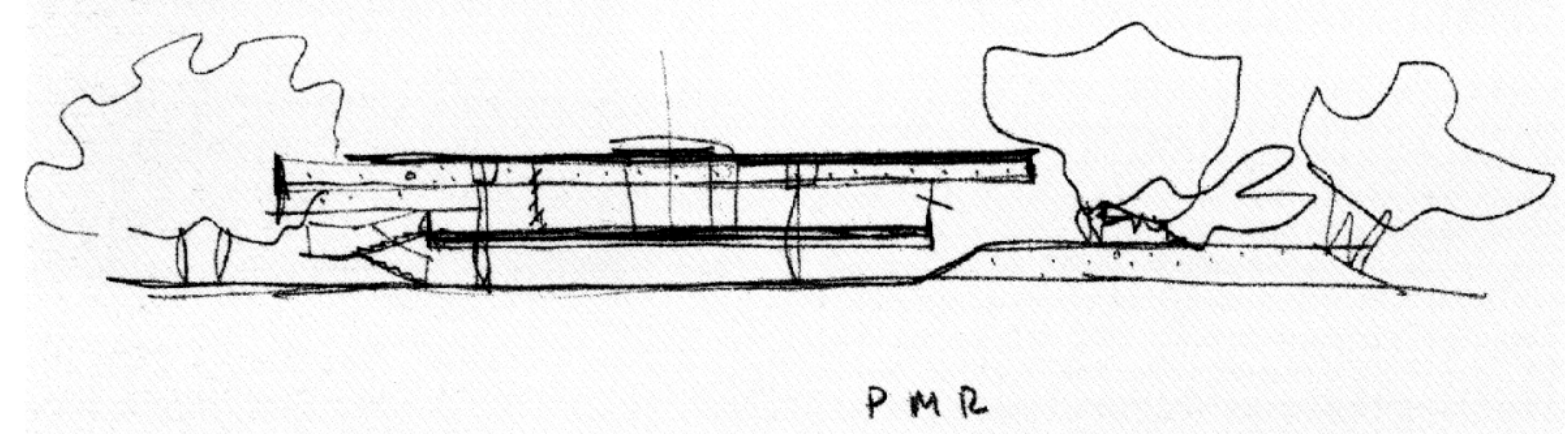

Figura 41 - Residência Butantã, 1964, croquis. Fonte: Piñón (2002, p. 44).

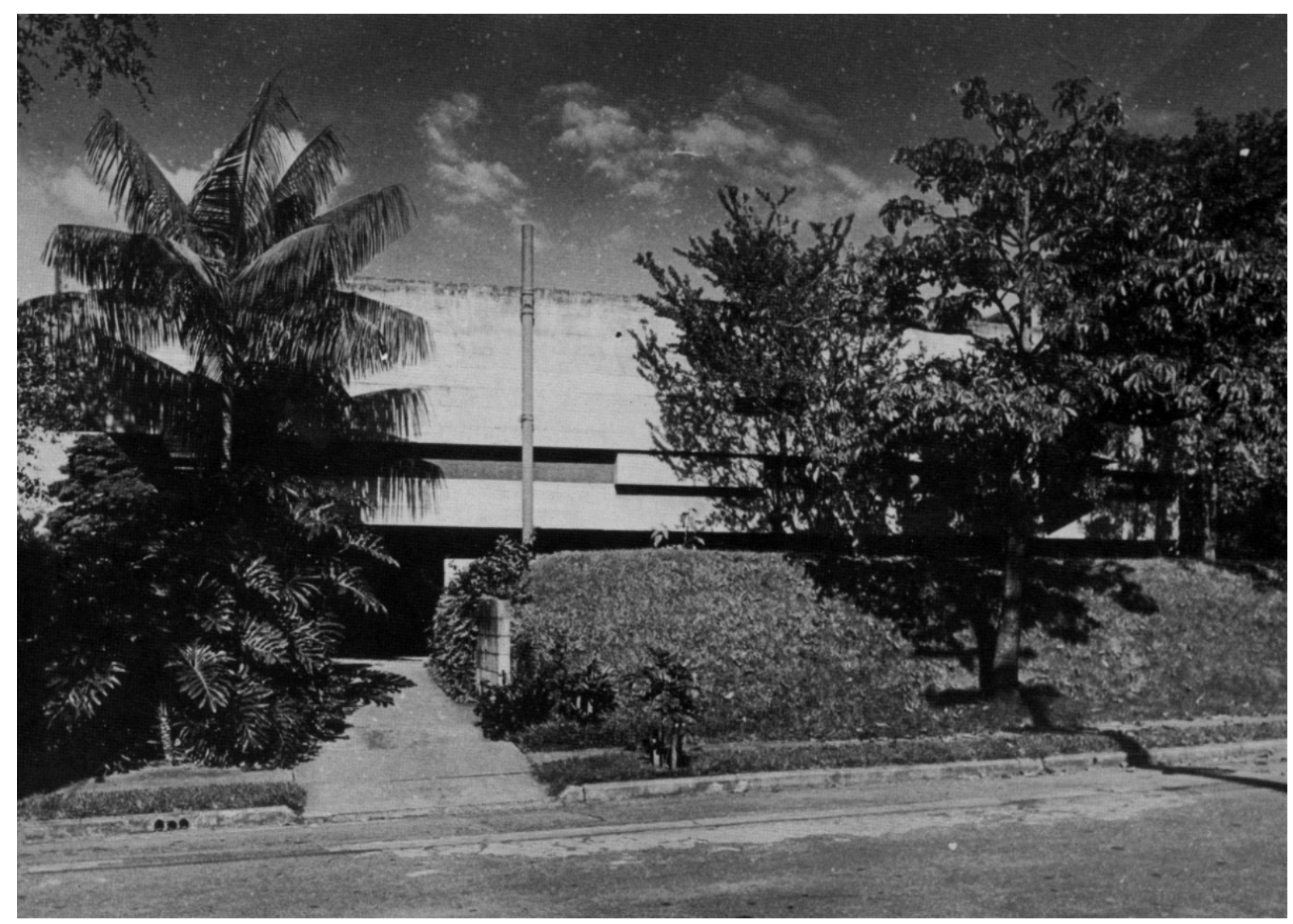

Figura 42 - Residência Butantã, 1964, exterior. Fonte: Acayaba (1986, p. 207). 
Assim, muito embora essa residência não tivesse condições de se converter em obra seriada, pôde manter semelhança com o desígnio da casa Ivo Viterito, não somente devido ao sistema cons trutivo que correspondia a quatro colunas, duas vigas e uma laje nervurada, mas pelo fato de que esse projeto de Mendes da Rocha trazia, em seu bojo, uma ambição replicável: mesmo sem convergir para um edifício pré-fabricado, foi mimetizada no desenho do seu dúplice - a casa vizinha, da irmã do arquiteto, que é uma flexibilização da sua.

O desejo inicial de padronização e a reprodutibilidade do sistema modular se limitou à experiência da duplicação de uma casa burguesa - também construída de maneira usual. Esse descompasso atesta a impossibilidade de consolidação das premissas de outrora - com relação à seriação -, além de estagnar o cerne de suas pretensões coletivas. Este contra-senso não impediu que essa linguagem arquitetônica fosse difundida, de acordo com Serapião (2004a), “como casa-símbolo do movimento local”, dada a adaptação da concepção corbusieriana à "tradição" da casa paulista. ${ }^{46}$

Assim, o bloco único é tornado uma caixa de concreto suspensa. Sob os pilotis, localiza-se o abrigo de automóveis, de onde se tem acesso ao espaço social, generoso e integrador de todas as funções. A cozinha linear, com equipamentos de ambos os lados, é reduzida ao essencial. Do mesmo modo, são os dormitórios, exíguos e sem aberturas, tais como as antigas alcovas. Os móveis em concreto, fundidos à obra, contribuem para o uso racional dos recursos, enquanto um talude artificial delimita um pátio interno abrigado da calçada, podendo se conformar como uma espécie de obstáculo.

\footnotetext{
${ }^{46}$ SERAPIÃO, F. Paralelos (e transversais) na história da casa paulista. Projeto, São Paulo, n. 287, p. 26-37, jan. 2004, p. 34. A residência Butantã, de Mendes da Rocha pode manter uma afinidade histórica com as casas tradicionais por vários motivos, um deles se manifesta no fato dos seus dormitórios serem pequenos e sem janelas, além disso, como define o referido autor, a sua implantação também sugere uma "relação topográfica" com a Casa Bandeirista (localizada defronte ao terreno em que se ergue essa casa do arquiteto capixaba), "situada sobre uma pequena elevação". Vale notar também que, a expressão "movimento local", pode ser uma referência ao que se convencionou chamar: "arquitetura paulista".
} 
Esse artifício que se interpõe entre a calçada e o lote, no discurso de Mendes da Rocha, pressupõe uma relação com a própria cidade, por recuperar uma topografia existente antes da paisagem ser "descaracterizada". Esta condição aceita a realidade que lhe é dada, fazendo menção ao entorno como um "território" de possibilidades. Assim, essa posição do arquiteto não admite o talude como forma de contraposição ao contexto. Em sua fala, Mendes da Rocha (1968) altera, portanto, uma política de repulsa à cidade vigente, presente nas obras de Artigas, tentando manter um diálogo com o espaço circundante. ${ }^{47}$

Embora o argumento de Castral (1998) proponha que as "barreiras concretas", presentes nos projetos de Artigas, tenham sido substituídas, na residência Butantã, por "barreiras topológicas", as quais supõem uma maior participação dos moradores “[...] na organização do modo de vida [...]" ${ }^{48}$, acreditamos na idéia de que esse "morrinho", de fato, configura uma forma de proteção menos agressiva para o interior da casa. Porém, esse elemento também sugere o abrandamento das ações que poderiam resultar numa reorganização do bairro e a dissimulação do caráter da propriedade particular, ao qual esse projeto de Mendes da Rocha fatalmente se submete.

Por isso, a suspensão da caixa e a escavação urbana, de onde nasce a estrutura da residência Butantã, revelam uma apropriação criativa na intervenção do existente, mas também uma política constituída sob as amarras da alcunha eminentemente burguesa. Se, até há pouco, a casa se encerrava ante seu entorno para se contrapor à realidade, primando por uma liberação dos ranços aristocráticos, sobretudo nas vísceras da residência, agora a

\footnotetext{
47 “[...] A casa que construí não restringe ninguém a um modo de vida específico e definitivo. Está mais ligada às possibilidades das coisas que farão do que a uma fórmula atual e pretensiosa, estática, apoiada nos costumes, como por exemplo, em relação à vida das crianças dentro de uma casa. Na minha, procurei ligar as crianças ao que enfrentarão fatalmente na vida real, e não submetê-las a uma proteção às vezes constrangedora." Cf. ROCHA, P. M. da. Casa de Concreto. Casa e Jardim, São Paulo, n. 156, p. 32-36, jan. 1968, p. 33.

48 CASTRAL, P. C. Territórios: a construção do espaço nas residências projetadas por Paulo Mendes da Rocha [décadas de 60 e 70]. São Carlos, São Paulo, dissertação de mestrado apresentada à EESC-USP, 1998, p. 69.
} 
arquitetura revisa as utopias, supondo um projeto aberto, mas que, de algum modo, perpetua os mesmos estigmas.

Em um momento em que a arquitetura internacional buscava repassar a validade dos pressupostos do movimento moderno, cada vez mais a produção paulista se fechava sobre si mesma, como um abono pelos tropeços da promessa coletiva. Assim, para combater essa visão de estreitamento das premissas modernas frente a uma aparente "crise" da capacidade de diminuir os problemas da sociedade, Artigas (1965) passa a defender que, se o funcionalismo não pôde atenuar as carências de toda a ordem, havia servido para a "superação de uma fase".

Nesse sentido, para Artigas, a arquitetura deveria se livrar de certa "ganga utópica", porque as mudanças qualitativas só poderiam ser oriundas do esforço conjunto de dominação da natureza e da técnica para alteração da estrutura social. Este discurso exime os artistas do colapso do intento da modernização e alimenta a crença em uma nação desenvolvida, mesmo depois do golpe militar. No entanto, a implementação do processo de industrialização segue sendo a chave para superar o subdesenvolvimento, embora sob o comando dos militares e, mesmo que, temporariamente, custasse para o país, todo o tipo de cerceamento das liberdades. ${ }^{49}$

Entretanto, às vésperas do AI-5, a confiança de Artigas na promessa de progresso, no otimismo da arquitetura como "uma atividade antecipadora" e em consonância com as forças produtivas se choca com o desapontamento das novas gerações de arquitetos, diante do "toque militar de recolher". Uma decepção que fica evidente no discurso de Ferro (1968), descrente nos ideais progressistas e certo de que os princípios revolucionários da arquitetura tinham se

\footnotetext{
49 ARTIGAS, V. Uma Falsa Crise. In: ARTIGAS, V. Caminhos da Arquitetura. São Paulo, Cosac Naify, 2004, p. 105. (artigo originalmente publicado em: Acrópole, São Paulo, ano 27, n. 319, p. 21-22, jul. 1965).
} 
convertido em um "maneirismo" - no "abuso de petrificação" e numa "esquematização rígida que denuncia[va] o aprofundamento da decomposição estrutural do país".

Talvez, essa condição faz com que Artigas, por um momento, repense suas teses quanto à capacidade da técnica alterar a situação do Brasil, não apenas mediante a instauração do governo antidemocrático, mas, principalmente, frente às insuficiências de sua própria aplicabilidade. Nesse sentido, logo depois de voltar do exílio, Artigas projeta a casa Elza Berquó (1967), uma residência que opera como uma espécie de revisão de seus pressupostos, na medida em que questiona a utilização do concreto armado como saída, ao mesmo tempo em que admite uma organização espacial mais livre.

Assim, ao invés das freqüentes colunas de concreto, são quatro troncos de árvore que passam a sustentar a grande cobertura. Nesses apoios, até mesmo os galhos não são desbastados, reforçando o sentido da exposição dos materiais em sua verdade. Todavia, a forma "tosca" com que a madeira é utilizada pode ser vista como uma ironia que subverte o que até então era uma denúncia - o "concreto desesperado" da casa Olga Baeta, na expressão de Artigas. Nessa suposição, é possível que Artigas satirize os disparates da concretude da arquitetura moderna em um país fadado ao atraso, colocando sob suspeita os seus próprios “avanços técnicos". 50

Sua reflexão, num curto espaço de tempo, passou a reconhecer os erros que foram cometidos no intento desenfreado de promover a industrialização da construção, sem que os meios estivessem disponíveis ou sequer houvesse alguma possibilidade de transferência "tecnológica" dos experimentos realizados nas residências burguesas para a casa popular.

\footnotetext{
${ }^{50}$ ARTIGAS, V. Vilanova Artigas: arquitetos brasileiros. São Paulo, Instituto Lina Bo e P. M. Bardi / Fundação Vilanova Artigas, 1997, p. 138. "[...] fiz essa estrutura de concreto apoiada sobre troncos para dizer, nessa ocasião, que essa técnica toda de concreto armado, que fez essa magnífica Arquitetura que nós conhecemos, não passava de uma tolice irremediável em face das condições políticas que vivíamos naquele momento [...].”
} 
Essa constatação põe Artigas de frente com seu passado, fazendo-o cogitar que todo ele pudesse ter sido uma grande ilusão. ${ }^{51}$
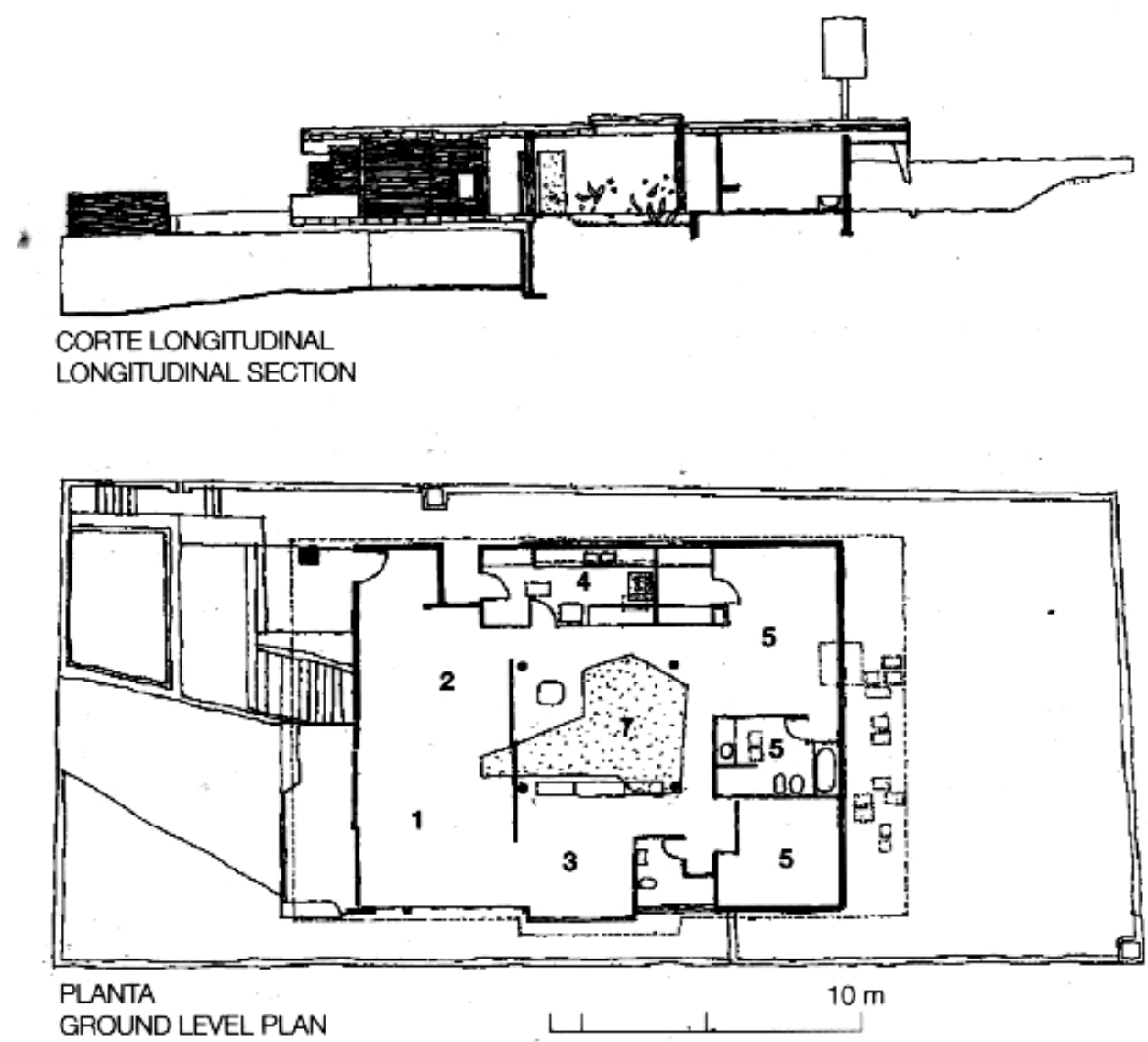
1.Sala
1.Living
2.Sala de Jantar
3.Estúdio
2. Dining
3. Studio
4.Cozinha
4. Kitchen
5.Quarto
5. Bedroom
6.Banheiro
6. Bathroom
7. Jardim
7. Garden

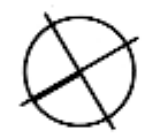

Figura 43 - Casa Elza Berquó, 1967, projeto. Fonte: Artigas (1997, p. 140).

\footnotetext{
${ }^{51}$ SCHWARZ, R. Posfácio. In: ARANTES, P. F. Arquitetura Nova: Sérgio Ferro, Flávio Império e Rodrigo Lefèvre, de Artigas aos mutirões. São Paulo, Editora 34, 2002, p. 227.
} 


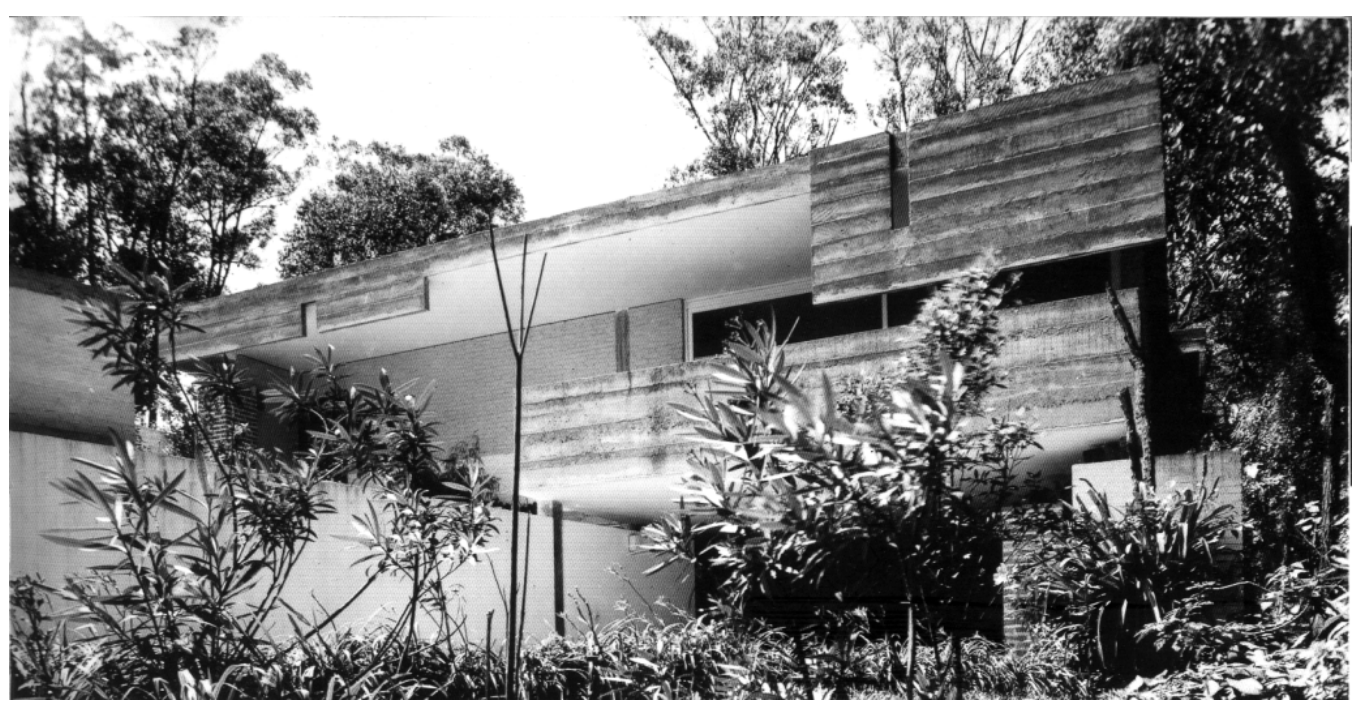

Figura 44 - Casa Elza Berquó, 1967, exterior, frente. Fonte: Artigas (1997, p. 139).

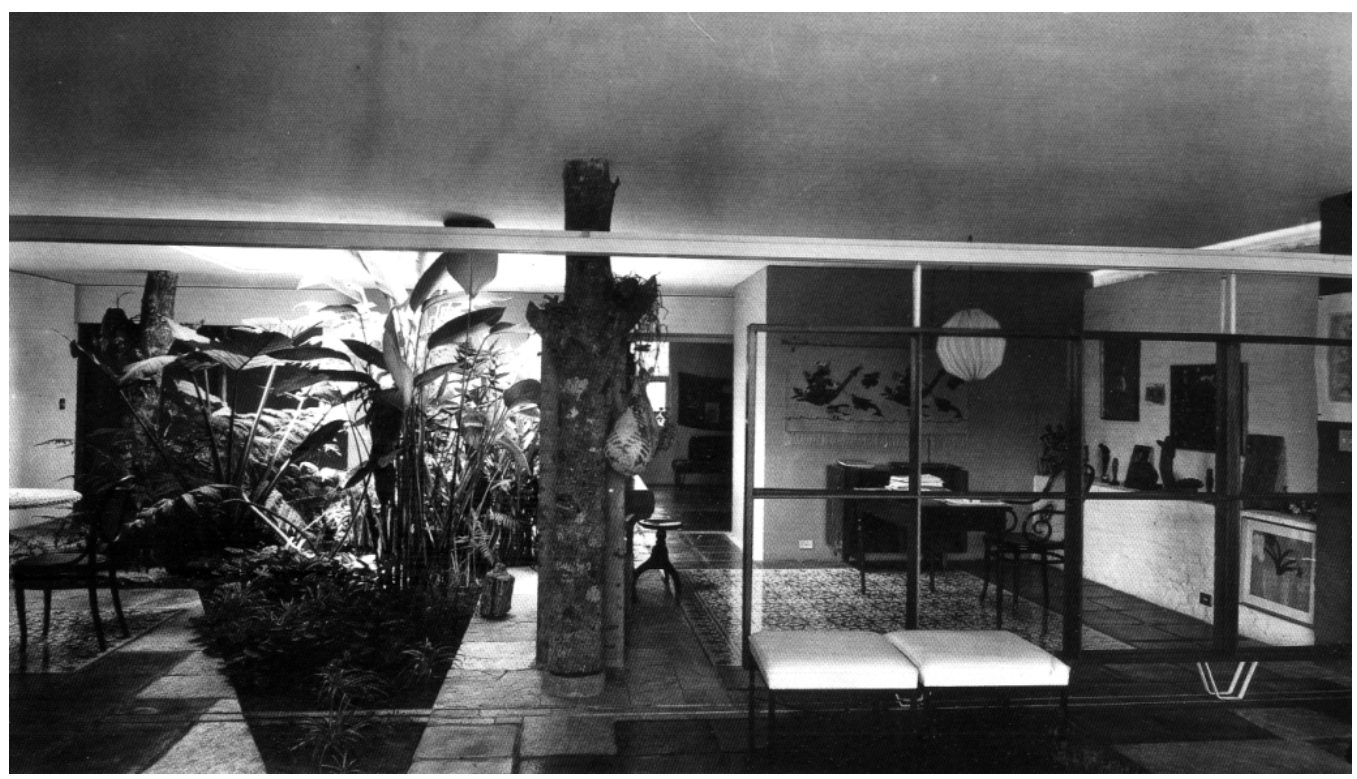

Figura 45 - Casa Elza Berquó, 1967, interior. Fonte: Artigas (1997, p. 140).

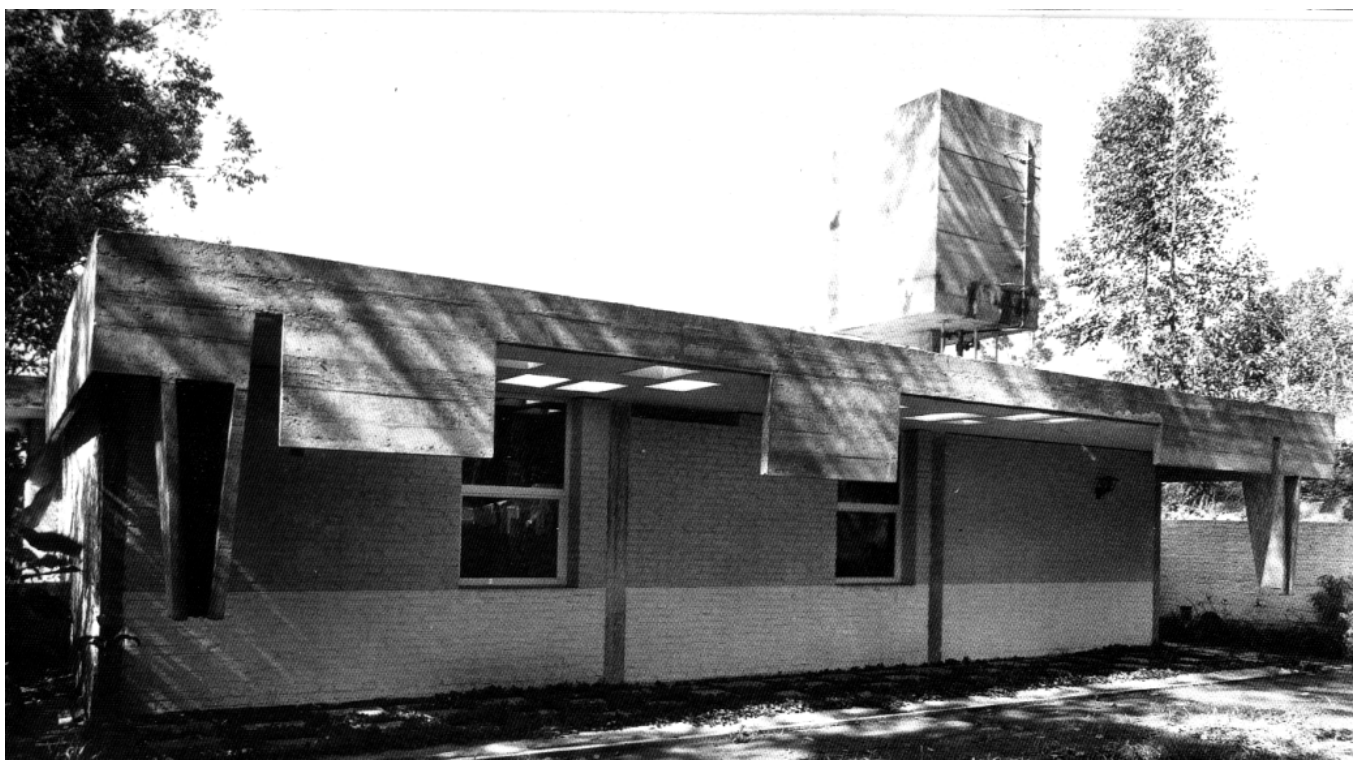

Figura 46 - Casa Elza Berquó, 1967, exterior, fundos. Fonte: Artigas (1997, p. 141). 


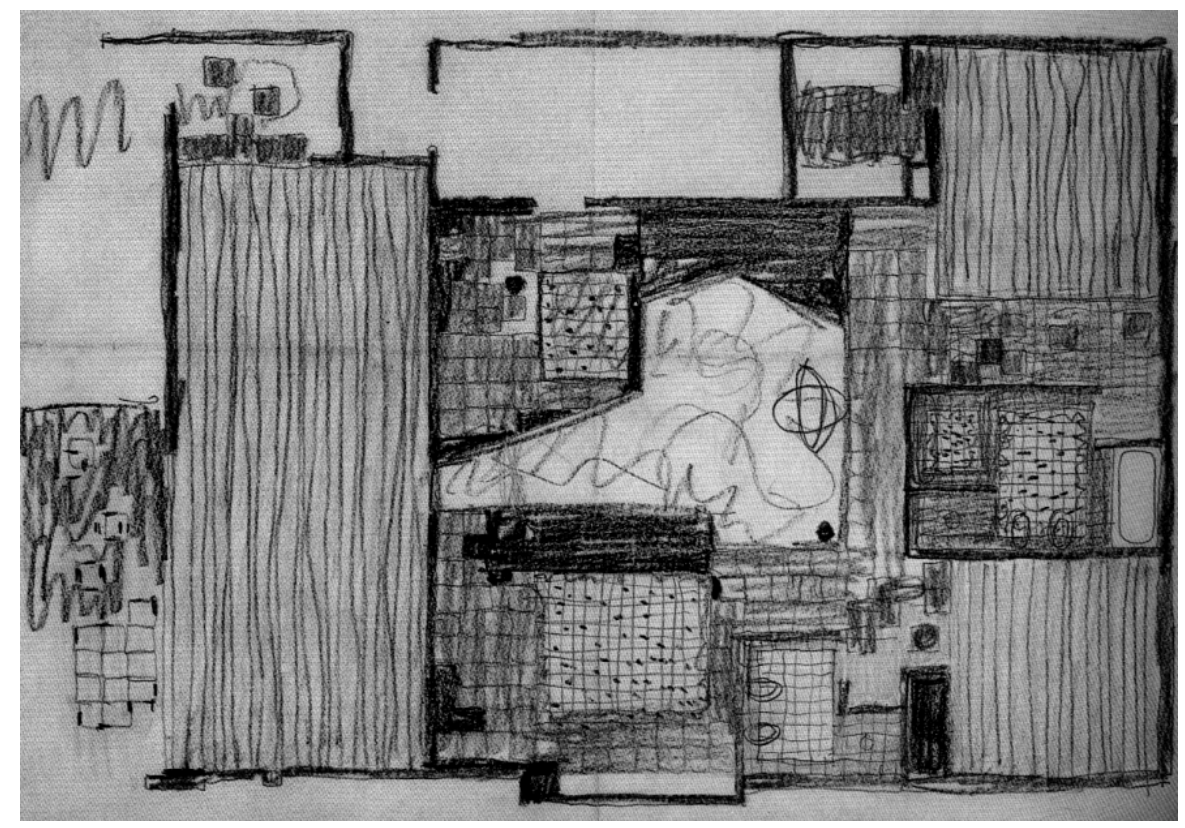

Figura 47 - Casa Elza Berquó, 1967, croquis. Fonte: Artigas (1997, p. 138).

Talvez por isso, o interior da casa Elza Berquó não apresente a ortogonalidade e a rigidez da casa Taques Bitencourt, já que o pátio central é composto por um perímetro disforme, ao inverso de um rigoroso polígono. Até mesmo os croquis dessa residência se produzem com traços soltos - uma liberdade que permite, a Artigas, poder se apropriar de diversos materiais e sobras comumente reaproveitadas nas casas populares, fazendo com que esse projeto apresente certa "desordem", estabelecendo um conflito com suas obras anteriores.

Nessa possibilidade, o arquiteto vê uma aproximação de suas idéias à maneira de construir do povo. Uma preocupação que também surge na vontade de fazer aparecer os arremates semi-acabados e o trabalho do pedreiro na construção - o que justifica a ausência de rodapés na casa Elza Berquó. A inexistência de iluminação no teto, também obriga o morador a despir-se de certo conforto, implicando, assim, numa apropriação mais inteligente dos recursos naturais. Entretanto, apesar dessas postulações mais complacentes, esse projeto 
ainda constitui uma residência burguesa que, diante dos anos de chumbo, funcionava, sobretudo, como um "refúgio". 52

Dessa maneira, ao mesmo tempo em que o projeto para a casa Elza Berquó põe em questão o fato de que a técnica do concreto armado poderia prover todas as mudanças requeridas para uma sociedade mais justa, continua encerrado sob grossas empenas, como obra individualizada. De tal sorte que as suas inversões constitutivas também não são capazes de se consolidar como uma ação efetivamente ligada à prática construtiva da grande maioria da população, sem poder concorrer para um redimensionamento dos conhecimentos oriundos das técnicas populares. ${ }^{53}$

De modo que, na obra de Artigas, a relação entre desenho e canteiro permanece dissociada, sobretudo, quando da oportunidade de projetar, junto com Paulo Mendes da Rocha e Fábio Penteado, o Conjunto Zezinho Magalhães (1967), em Guarulhos, nos anos da ditadura militar. Trata-se de um projeto destinado a 60 mil pessoas, voltado para a construção de habitação popular para famílias de baixa renda, mas que, mesmo diante dos impasses da industrialização da construção, considerando-se a utilização de métodos construtivos mais facilmente assimiláveis, opta por um sistema com componentes pré-fabricados.

Novamente, nesse projeto, a idéia de que a mecanização poderia se constituir como uma resposta para o déficit habitacional no Brasil é posta de ponta cabeça, porque nenhuma empreiteira aceitou fabricar os painéis que seriam utilizados na construção dos blocos e os órgãos estaduais também se recusaram a arcar com os altos custos que seriam demandados

\footnotetext{
${ }^{52}$ CORRÊA, M. L. Artigas: da idéia ao projeto. São Paulo, dissertação de mestrado apresentada à FAU-USP, 1998, p. 204. Esse trecho se refere ao depoimento de Elza Berquó.

${ }^{53}$ Faço referência aqui à "atividade criadora" surgida de uma apropriação da condição arcaica do país, dos materiais rudimentares e da mão-de-obra disponível, na abóbada que vai até o chão, funcionado como coberturaabrigo, do grupo Arquitetura Nova. Muito embora seja preciso ressaltar também que as casas construídas por Sérgio Ferro, Flávio Império e Rodrigo Lefèvre, apesar de adotarem o "miserabilismo" e a improvisação na arquitetura como um modo de caminharem para sua "popularização e autonomia" eram destinadas a um público burguês. Cf. KOURY, A. P. Grupo Arquitetura Nova: Flávio Império, Rodrigo Lefèvre e Sérgio Ferro. São Paulo, Romano Guerra / Edusp, 2003, p. 56.
} 
para tanto. Assim, o conjunto acabou sendo edificado de maneira usual, contribuindo para a tarefa massacrante à qual está submetido o trabalhador na construção civil, aguçando o descompasso entre o que é pensado na prancheta e o que é, de fato, executado na obra. ${ }^{54}$

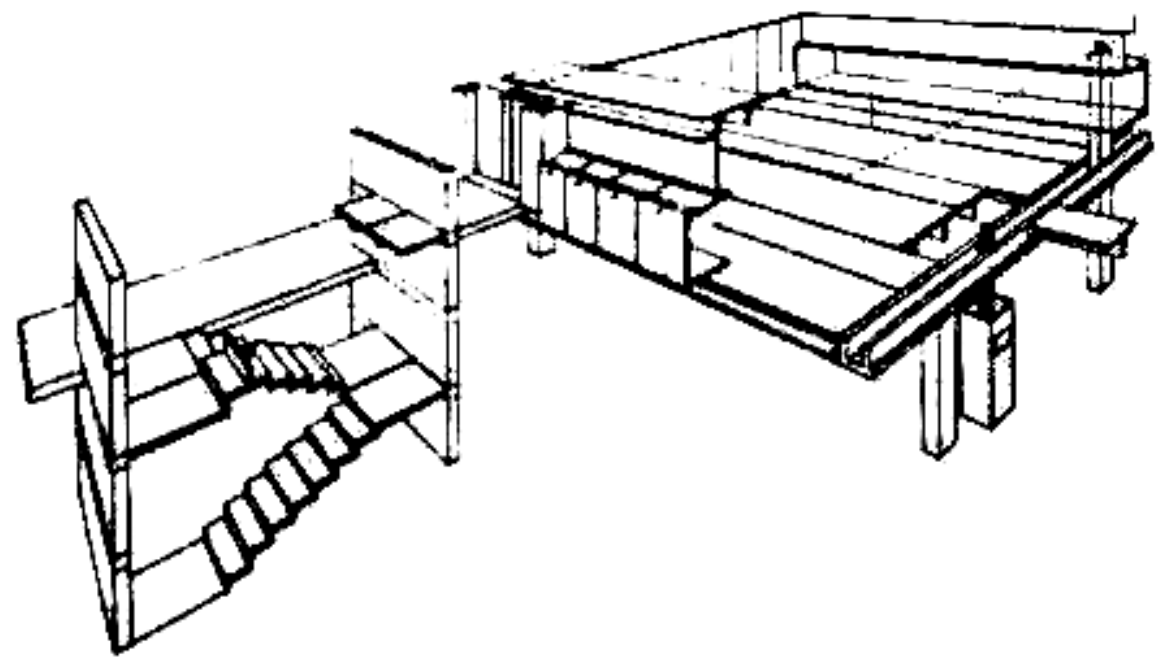

Figura 48 - Conjunto Zezinho Magalhães, 1967, projeto original com componentes industrializados. Fonte: Arantes, P. F. (2002, p. 102).

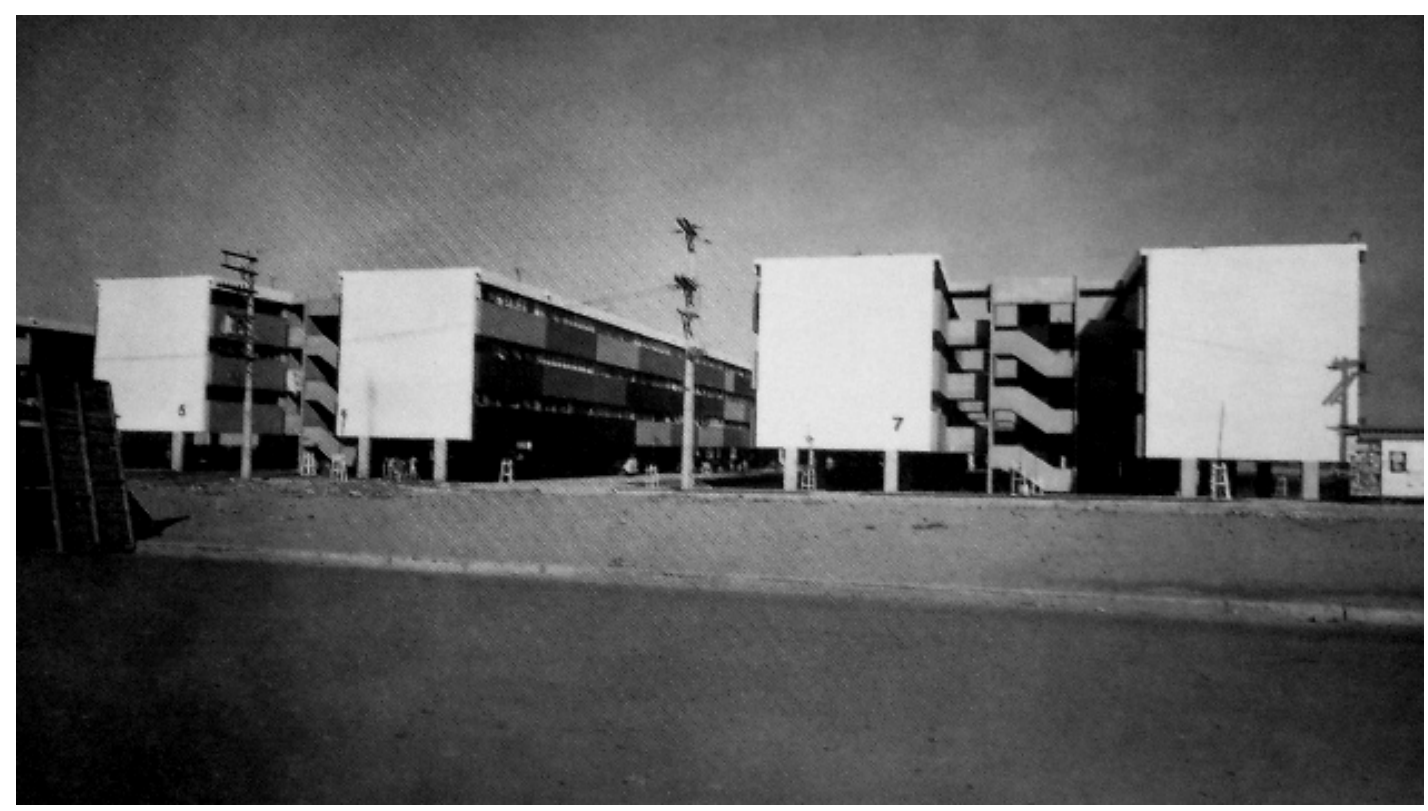

Figura 49 - Conjunto Zezinho Magalhães, 1967, exterior. Fonte: Artigas, R. (2002, p. 189).

\footnotetext{
${ }^{54}$ Refiro-me aqui às preocupações de Sérgio Ferro no seu livro "O canteiro e o desenho" - quando formula uma resposta às questões que não foram avaliadas pelo mestre Artigas em sua aula "O Desenho" (1967), especialmente, nas dissociações que as imposições presentes no desenho dos arquitetos produzem no canteiro de obras. Cf. FERRO, S. O Canteiro e o Desenho. São Paulo, Prolivros, 2005.
} 
Embora o Conjunto Zezinho Magalhães tenha, mais tarde, servido como padrão para outras propostas implementadas pelos programas estatais de habitação, nas quais se incluem projetos do próprio Artigas, o fracasso da pré-fabricação conduzia para um mal estar que não apenas impedia a implantação de todo o projeto, mas, também, ratificava as mazelas do Brasil. Contraditoriamente, apenas no regime autoritário se fazia possível a tradução das teses ensaiadas nas casas burguesas para um projeto de âmbito coletivo - agora sob a ultrajante condição de dois dos seus autores sumariamente cassados da condição de professores da FAU/USP. ${ }^{55}$

Assim, o que era uma tentativa de produção quase artesanal nas primeiras casas destinadas à burguesia, visando à constituição de um projeto extensível - apesar dos ranços inerentes a esse desejo -, se transforma em modo de compensar a "frustração crescente dessas propostas", como atesta Ferro (1968). Conseqüentemente, o comprometimento da técnica com um ideário de progresso econômico e social não muda de lado, mas desvela seu verdadeiro sentido: a alimentação de uma luta em vão, cuja batalha, há muito, tinha sido perdida, porque enquanto se pensava estar formulando uma resposta coletiva, o "modelo" apenas ia acalentando o status quo.

Nesse prisma, a conformação do concreto armado nas casas burguesas pode ser lida como uma proposta que aparentava um "desenvolvimento esperado", enquanto não se podia reverter o quadro de atraso do país. Nesse caso, as posições políticas de Artigas deixam de ser "atitude agressiva" em face da realidade conflitante, tal como supõe Ferro (1968), para serem apropriadas como uma representação "substitutiva e conciliadora". 56

\footnotetext{
55 THOMAZ, D. Vilanova Artigas. [Documento]. AU, São Paulo, n. 50, p. 77-90, out./nov. 1993, p. 85. Em 1969, a poucos dias da inauguração do novo prédio da FAU/USP na Cidade Universitária, João Batista Vilanova Artigas, Paulo Mendes da Rocha e Jon Maitrejean foram compulsoriamente afastados da escola.

56 FERRO, S. Arquitetura Nova. In: Arte em Revista, São Paulo, n. 04, p. 89-94, ago. 1980, p. 92. (artigo divulgado em 1966 e originalmente publicado em: Teoria e Prática, São Paulo, n. 1, 1968). De acordo com esse autor, mais uma vez, a mídia - através das revistas especializadas -, e também a especulação imobiliária,
} 
Sob essa premissa, a casa burguesa ultra-compactada, realizada a partir de uma postura crítica, passa a ser mais um produto, agora da técnica como um fim em si mesmo. A casa Telmo Porto (1968), de Artigas, na cidade de São Paulo, reitera essa condição. Apoiada em apenas um pilar, leva às últimas conseqüências a capacidade de criação do arquiteto, enquanto se encapsula nos limites do terreno e nas quatro fachadas, configurando um fechamento quase que total, em relação à rua. Esta composição torna o discurso político de rechaço à cidade capitalista, cada vez mais, um recurso formal.

Nesse horizonte, não há mais frente de combate nem a utopia de alterar o que está à sua volta. Apenas restou o verso - um projeto coletivo às avessas, ou seja, a casa burguesa e o seu interior, todo iluminado por domos e interligado por longas rampas que levam para o velamento da carga ideológica: um volume encastelado, muito abrandado das idéias que motivavam sua destinação social.

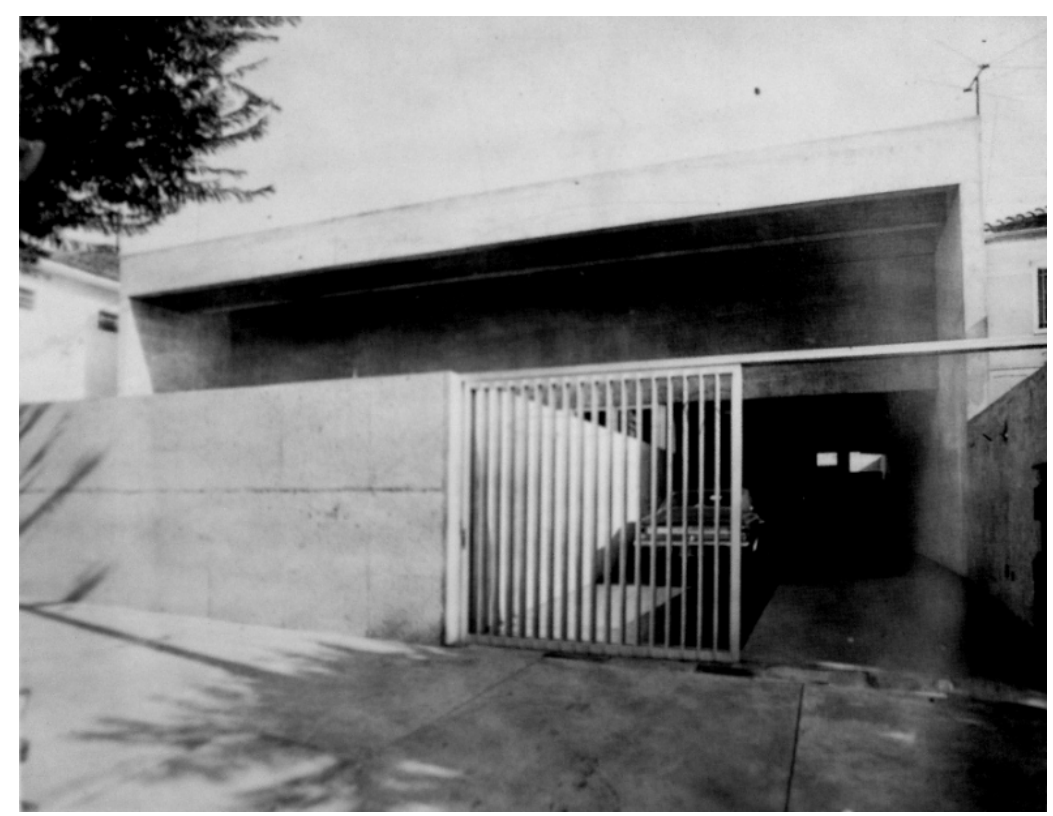

Figura 50 - Casa Telmo Porto, 1968, exterior. Fonte: Artigas (1997, p. 159).

trataram de referendar uma linguagem arquitetônica, "selecionando" as propostas menos hostis para servir de "agente de vendas". Esta motivação colaborou para que os profissionais se vissem cada vez mais trancafiados às obras particulares, tais como as residências burguesas, lojas e clubes, numa arquitetura que apenas se tornou viável pelo encarceramento de suas próprias posições políticas, mediante as trocas, num comércio "privado", dos pressupostos que deveriam servir a um projeto "coletivo". 


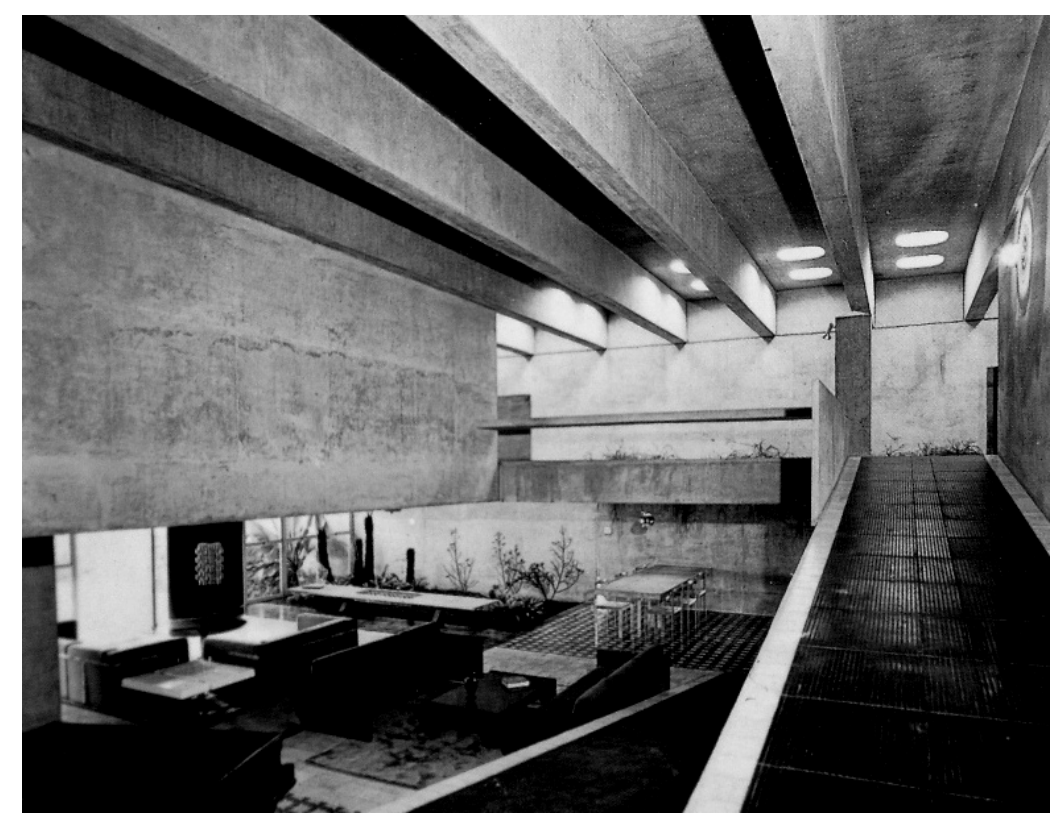

Figura 51 - Casa Telmo Porto, 1968, interior. Fonte: Artigas (1997, p. 158).

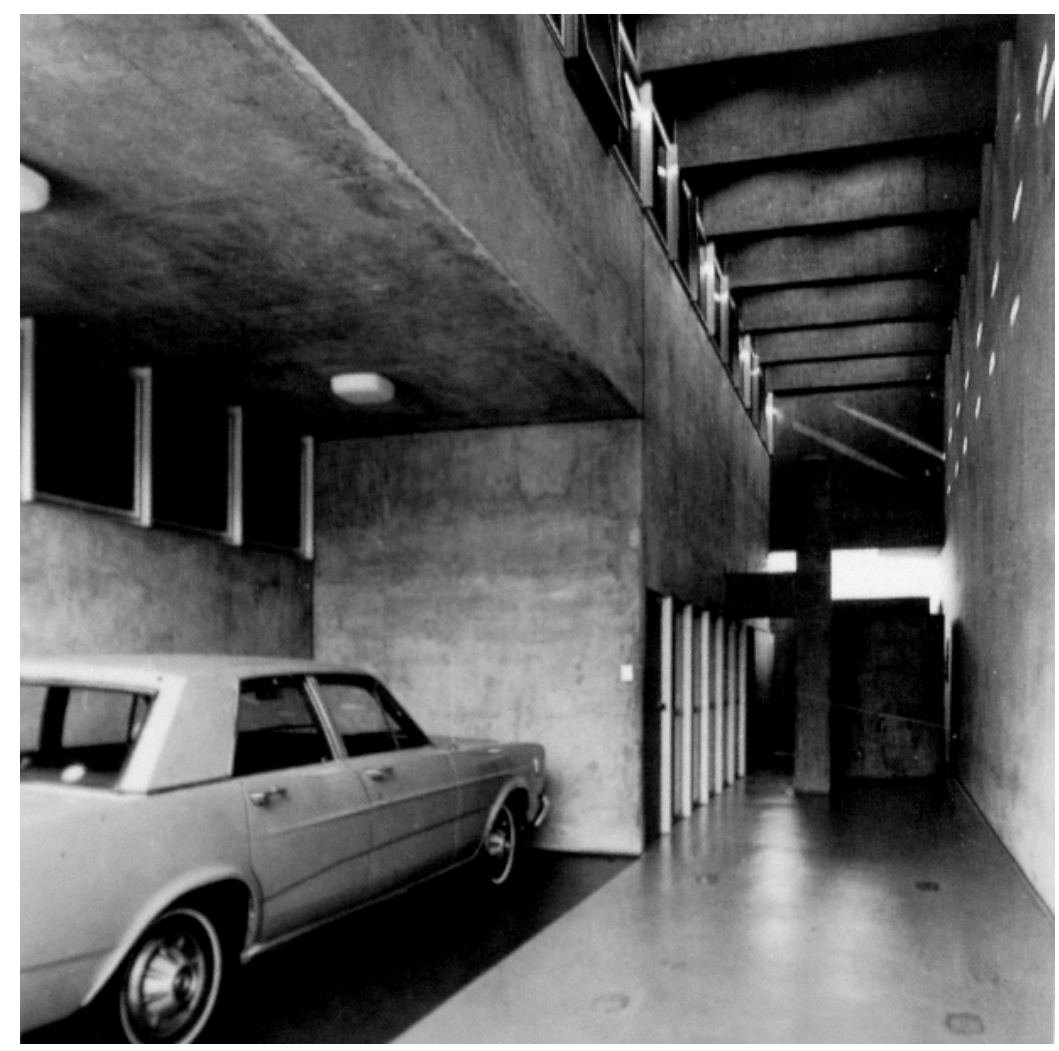

Figura 52 - Casa Telmo Porto, 1968, acesso. Fonte: Artigas (1997, p. 158). 


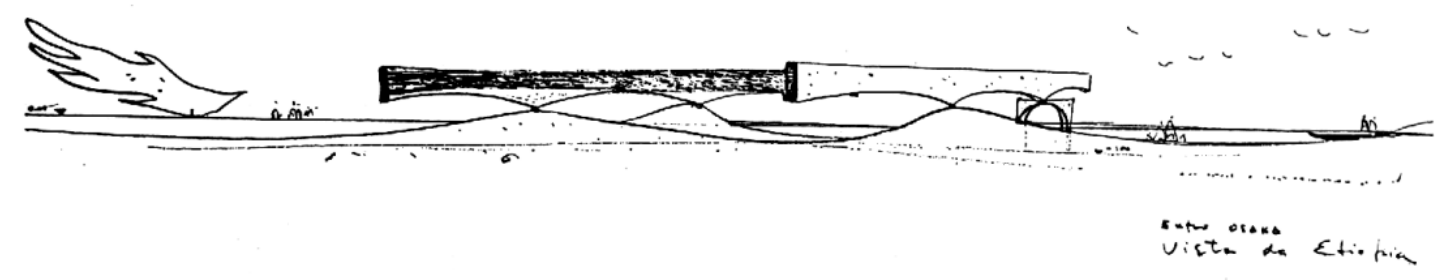

2.2. A técnica como álibi 
Os percalços para a consecução de uma arquitetura que pudesse ser canalizada para a industrialização da construção e, assim, ter como horizonte a melhoria das condições de vida da população, se mostraram inúmeros. Embora algumas obras começassem a ser erguidas sob a égide dos anos do chamado "Milagre Econômico", os obstáculos para a concretização de uma promessa de estandardização arquitetônica, bem como a reordenação da cidade para fins coletivos, impediam que os anseios de Artigas pudessem ser postos em prática, o que o colocava em postura de constante exame das possibilidades para uma alteração da realidade.

Deste modo, no discurso de Artigas (1969), a casa ainda permanece como "o ponto de partida para outros desenhos", pois na medida em que diversos programas fossem aceitando "novos tratamentos formais", oriundos de uma concepção espacial incubada nas residências, poderia ser possível o encontro da casa com a cidade, viabilizando a construção de uma "nova sociedade". Esta idéia, mesmo diante da "crise" dos pressupostos do projeto moderno, firma sua fé na racionalidade, entendendo-a como exercício da experimentação artística e da "pesquisa tecnológica".

Entretanto, essa proposição de Artigas busca por uma arquitetura como manifestação que encerra métodos próprios, afirmando sua lógica interna enquanto arte e não como resolução que lhe é imposta pela ciência ou tecnologia. Nesse sentido, em oposição às obras como simples construções que apenas tinham como norma a pura estabilidade, o projeto da casa conserva-se como uma paragem onde o arquiteto poderia "desenvolver plenamente sua criatividade".

Assim, perante a dificuldade para a tomada dos meios de produção, a posição de Artigas, em plena ditadura militar, ratifica o domínio da técnica do concreto armado, justamente pela capacidade dos arquitetos brasileiros em tirar partido das situações desfavoráveis, garantindo um modo de expressão próprio que se distingue pela "absorção 
crítica dos critérios criadores", contribuindo para delinear uma "nova linguagem formal". Dessa maneira, enquanto a "cidade" e a "casa" permaneciam como realidades isoladas, restava então reafirmar uma atitude. ${ }^{57}$

Nesse caso, para Artigas, a casa funcionava como esfera de gestação da técnica, para que esta pudesse intermediar a constituição da cidade, pois, no projeto da habitação, seria possível articular o espaço em âmbito mais amplo, sem recair em velhas formas, na perspectiva de consecução da produção arquitetural em larga escala. Assim, Artigas lança mão de uma ação que tenta reverter o ceticismo em torno do desenho, revelando um posicionamento marcado na crença em uma destreza da técnica brasileira, mesmo frente aos impasses do processo de industrialização.

Por conta disso, Artigas procura adotar partidos inusitados, apenas possíveis de serem conseguidos por meio de uma apropriação característica dos princípios modernos, excetuando as soluções funcionalistas e procurando dar relevância às saídas criativas, as quais, em sua visão, poderiam vir a ser mais aptas para uma transformação do estado de coisas. O projeto de Artigas para a casa Martirani (1969), em São Paulo, traz alguns traços desse escopo, pois permite, tanto na espacialização como nas técnicas de construção utilizadas, uma leitura que releva um caráter singular à obra, talvez até radicalizando os possíveis maneirismos, assimilados pelo senso comum.

Na casa Martirani, a ala social e intima da residência está localizada no segundo e no terceiro pisos, respectivamente, ambos com traçado mais retilíneo e interligado por rampas de concreto armado. O térreo, com um desenho mais orgânico, oculta as áreas de serviço, garagem e lazer. Todavia, o que parece ser uma oposição entre uma tendência organicista e

\footnotetext{
57 ARTIGAS, V. Arquitetura e Construção. In: ARTIGAS, V. Caminhos da Arquitetura. São Paulo, Cosac Naify, 2004, p. 120. (artigo originalmente publicado no Catálogo da IX Bienal de São Paulo, em: Acrópole, São Paulo, ano 31, n. 368, dez. 1969).
} 
uma linha racionalista da arquitetura - que marcaram o início da carreira do arquiteto - pode então se constituir como desapego de ambas, fazendo valer a opinião de Artigas (1981) sobre a "valorização mais ampla" do "significado humano", inerente à determinação das formas arquitetônicas.

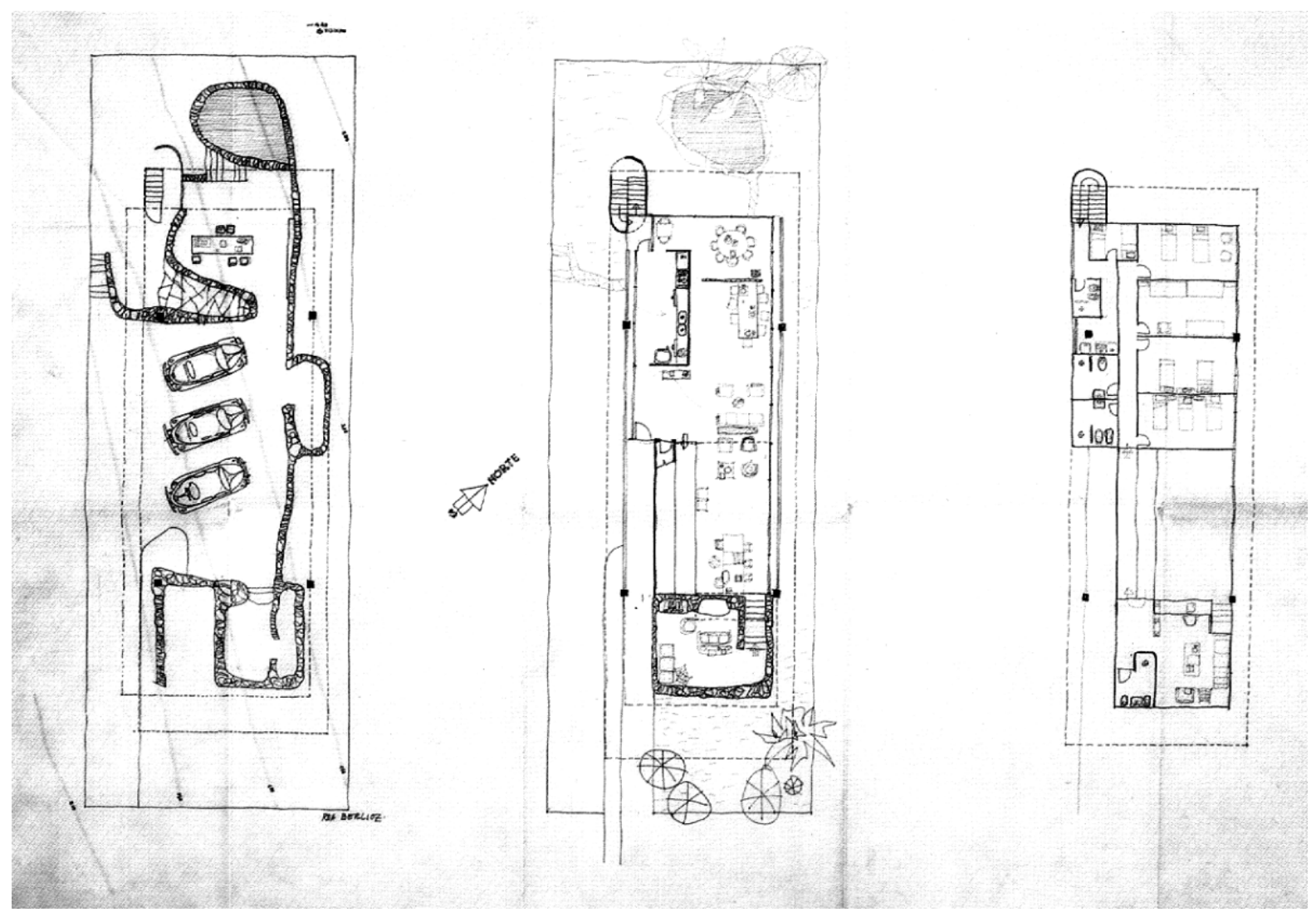

Figura 53 - Casa Martirani, 1969, plantas, croquis . Fonte: Artigas (1997, p. 164).

Nesse sentido, nos andares superiores da casa Martirani, apesar da delimitação rígida configurada pela caixa de concreto que os envolve, pode ser lida uma organização contínua dos espaços, possibilitada pelo grande vão - o que faz do lugar comum, um local de fruição. Sendo assim, Artigas o imagina como ambiente onde as pessoas se reúnem, conversam e interagem, na medida em que podem desempenhar livremente suas funções rotineiras ou esporádicas. 


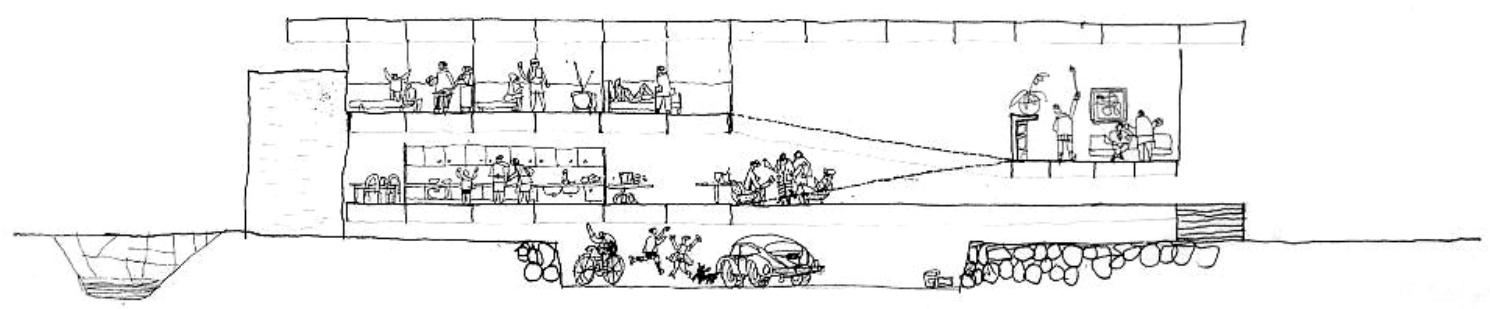

Figura 54 - Casa Martirani, 1969, corte ilustrado. Fonte: Artigas (1997, p. 166).

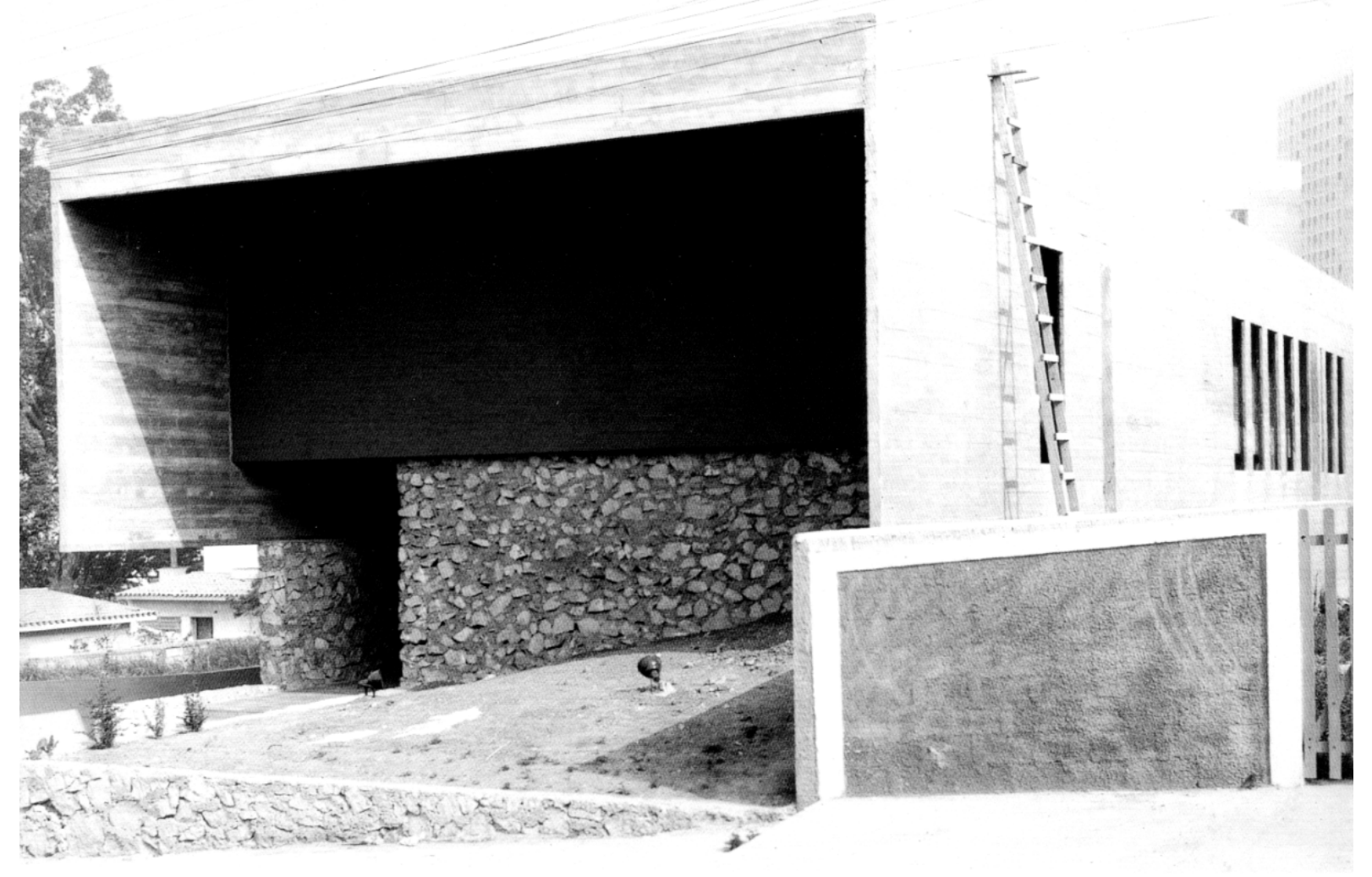

Figura 55 - Casa Martirani, 1969, exterior. Fonte: Artigas (1997, p. 165). 
Essa mesma idéia também pode ser percebida nas linhas sinuosas que compõem a casa junto ao solo. Entretanto, as formas ali empregadas constituem uma diagramação mais aberta, admitindo possibilidades para que o espaço agasalhe um maior número de usos. Por isso, a garagem também serve como um passeio, no qual as crianças brincam e andam de bicicleta, ao passo que a piscina - além de ambiente lúdico, pelo fato de ser projetada como cancha represada por um arrimo de pedras - tende a se configurar como um lugar de contemplação.

Nesse caso, os riscos soltos que configuram o primeiro plano da casa Martirani, onde surge um muro-fundação constituído por pedras, podem extravasar a necessidade do abrigo. Se, por um lado, a apropriação desse material, em certo sentido, põe à mostra uma "soleira" um tanto quanto primitiva, por outro, também pode inverter o teor mecanicista da arquitetura como máquina de morar, dos pioneiros do Movimento Moderno europeu.

Sendo assim, a exemplo da casa Elza Berquó, a constituição da casa Martirani poderia flagrar os conflitos na apropriação de técnicas construtivas que fazem vistas a um país "subdesenvolvido", no qual os métodos de construção mais utilizados são, em sua grande maioria, tradicionais. Porém, apesar de ser possível um caráter contestatório da casa Martirani, essa realidade não impedia o uso do concreto armado, levando Artigas a acreditar que, embora existissem dificuldades a serem superadas, um domínio da técnica ainda resguardava um desígnio ao desenho.

Se o plano superior da casa Martirani sublima as possibilidades do concreto armado, o nível inferior as decanta pela apropriação da aglutinação em pedra que subverte certo rigor científico. Nesse caso, configura-se uma posição intrigante, pela qual o conjunto construtivo ratifica as propriedades da técnica e, ao mesmo tempo, assume o fato de que o salto da industrialização da construção ainda estaria por acontecer. Sob essa condição, Artigas pôde manter sua postura ideológica, tendo em vista políticas de enfrentamento e deflagração das 
deficiências tecnológicas do país, nutrindo otimismo em relação à técnica, apesar desta, no caso brasileiro, se constituir como um mito. ${ }^{58}$

Talvez porque, para o arquiteto, por meio das experiências técnico-criativas seria possível promover uma maneira de enriquecer um conhecimento que recusa a mera aplicabilidade de soluções, contribuindo para a ampliação dos horizontes qualitativos da arquitetura. Assim, no pensamento de Artigas (1981), apesar do "atraso tecnológico", as "raízes brasileiras" revelavam, sobretudo, "todo um projeto de progresso econômico e social" que poderia "ser uma contribuição para o progresso universal". Deste modo, nossas reminiscências construtivas não impediam que a arquitetura pudesse expressar um "avanço audacioso": "[...] as proezas construtivas que o conhecimento cada vez maior da técnica do concreto armado possibilita". 59

Entretanto, essa visão de avanço nunca foi a mesma do desenvolvimentismo que era empreendido no país desde a ditadura de Vargas. Nem as grandes obras, tais como as estradas, as pontes e as hidrelétricas, construídas como resultado do engenho nacional durante

\footnotetext{
58 "[...] o mito da técnica trouxe de volta velhas contradições da civilização maquinista. No caso brasileiro a retórica tecnológica adquire a forma sublimada do atraso. É nesse sentido que o trabalho de Artigas é mais a negação da técnica que uma premissa tecnológica das possibilidades nacionais da construção da arquitetura. Técnica - estrutura - como mito e programa social como horizonte. Esse conflito moderno atualizado na conjuntura brasileira faz dessa arquitetura um comentário sobre o impasse do projeto nacional, que nos anos seguintes se confirmarão." Cf. RECAMÁN, L. Os Impasses da Arquitetura Paulista Recente. In: DO_CO, MO.MO BRASIL, 3, 1999, São Paulo. Anais do $3^{\circ}$ Seminário DO_CO, MO.MO a permanência do moderno. 1999, p. 07. (arquivo em formato pdf).

${ }^{59}$ ARTIGAS, V. Arquitetura e Comunicação. In: ARTIGAS, V. Caminhos da Arquitetura. São Paulo, Cosac Naify, 2004, p. 135. (artigo escrito em 1970, publicado pela primeira vez em: ARTIGAS, V. Caminhos da Arquitetura. São Paulo, Livraria Editora Ciências Humanas, 1981). Anos mais tarde, Artigas deixará clara essa crença: "[...] O Brasil avançou muito na técnica do concreto armado e já exportamos know-how. Exportamos criatividade, basicamente. Você faz uma proposta audaciosa, como a do Oscar Niemeyer para Argélia, e os engenheiros franceses dizem que é impossível calcular. Então você chama um engenheiro brasileiro para mostrar que é possível calcular. Aí os franceses dizem que é impossível construir. E você chama uma empresa brasileira - e ela constrói. A criatividade, a intuição podem ser uma fórmula de abrir portas nos mercados internacionais. Isso naturalmente, está ligado à idéia de fazer pesquisas de ponta. Ou não fazer, e largar o brasileiro como sendo o homem que assimila de cambulhada aquilo que lhe é oferecido pela criatividade internacional, para o seu desenvolvimento. - Então, do seu ponto de vista não se trata de refazer o caminho que todas as sociedades desenvolvidas percorreram? - Não, é sair com a própria originalidade, criatividade e daí para frente." Cf. ARTIGAS, V. As idéias do velho mestre. In: ARTIGAS, V. Caminhos da Arquitetura. São Paulo, Cosac Naify, 2004, p. 169. (entrevista ao jornalista Paulo Markun realizada em 10 de novembro de 1984 e publicada alguns dias após a sua morte, em: Folha de São Paulo, São Paulo, 19 jan. 1985).
} 
o regime militar, de fato, condiziam com a necessidade de melhoria de vida da população.

Dessa maneira, as façanhas estruturais moldadas pelo esforço da nação em parecer moderna, nada tinham a ver com um projeto coletivo, já que funcionavam como os símbolos da própria tecnocracia governamental e do processo de expansão do capital.

De certo modo, em oposição ao que Artigas imaginava, os feitos técnicos que se evidenciavam em algumas de suas obras referendavam uma prática arquitetônica desvencilhada da possibilidade de cumprimento do papel ao qual se destinavam. Se considerarmos o percurso desde a casa Telmo Porto, o projeto da casa Martirani reforça a caixa de concreto armado como formalização arquitetônica que encurrala o seu conteúdo político, porque poderia ser compreendid a pelo viés da própria realidade brasileira, ou seja, uma "unidade de contrários", em que o moderno somente se mantém pela simbiose com o que há de mais arcaico - nos valendo de um argumento de Oliveira (1972). ${ }^{60}$

Ao ser destroçada a ideologia de modernização "etapista" do PC que, em tese, alteraria a estrutura de classes, a lógica capitalista vai sendo deflagrada: a exploração do operário na indústria e da mão-de-obra mal qualificada no canteiro. É, nesse sentido, que a técnica do concreto armado como possibilidade de progresso vai sendo posta em xeque, porque nutre as formas de opressão do trabalhador submetido aos baixos salários, enquanto constrói o lastro dos interesses das elites que o financia. E, se essa retro-alimentação é conjuntural e não pode ser rompida, nos termos do pacto com a burguesia, colocará sob suspeita a modificação do quadro das mazelas sociais no Brasil.

Mesmo assim, o "know how" técnico-criativo era um álibi para comprovar a habilidade do profissional brasileiro diante das incongruências do país, fazendo com que Artigas seguisse com sua confiança na possibilidade de uma reviravolta, levando em conta um

\footnotetext{
${ }^{60}$ OLIVEIRA, F. A economia brasileira: crítica à razão dualista. In: OLIVEIRA, F. Crítica à razão dualista - O ornitorrinco. São Paulo, Boitempo, 2003, p. 32. (artigo publicado pela primeira vez em 1972).
} 
propósito ainda maior, pois, de algum modo, para o arquiteto, as construções emblemáticas que foram erguidas no Brasil, também podiam evidenciar uma contribuição cultural para o mundo contemporâneo.

Esse sentido se exprime no projeto vencedor para o Pavilhão do Brasil da Expo' 70 de Osaka (1969-70), de Paulo Mendes da Rocha, Jorge Caron, Júlio Katinsky e Ruy Ohtake: pela grande cobertura de concreto armado, engendrava-se a demonstração do trabalho do povo brasileiro, tendo em vista um "significado humanístico". 61

Este projeto, de acordo com Motta (1970), emerge de uma "visão histórica", como uma aglutinação das obras de Lúcio Costa, Niemeyer e Artigas, porém de modo que essas não fossem apenas entendidas como uma manifestação limitada ao país ou às condições de produção que nos eram peculiares. Assim, o pavilhão se lança com um comprometimento de "ir além", orientando-se sincronicamente, como uma "[...] maneira de apresentar as possibilidades que se acumulavam historicamente, dentro de um país, no sentido de produzir projetos de universal interesse". ${ }^{62}$

É por conta disso que o Pavilhão do Brasil para a Expo' 70 de Osaka conserva a concepção da grande cobertura, já que no discurso de Mendes da Rocha, além de um intento de firmar a importância dessa estrutura para nós - no interesse de "levar o teto da FAU-USP para outro lugar" -, ratifica a acepção "que vem de uma tradição antiga". Então, a cobertura é entendida por Mendes da Rocha como "[...] uma peça fundamental da arquitetura, seja ela uma cúpula de Bernini, seja ela um telhadinho camponês". E sua instalação, marca um "território" e o constitui como um "espaço humano". ${ }^{63}$

\footnotetext{
${ }^{61}$ ROCHA, P. M. da. Pavilhão do Brasil na EXPO'70. Acrópole, São Paulo, n. 361, p. 13-27, maio 1969, p. 15. ${ }^{62}$ MOTTA, F. Arquitetura Brasileira para a EXPO'70. Acrópole, São Paulo, n. 372, p. 25-31, maio 1970, p. 25.

${ }^{63}$ ROCHA, P. M. da. Cultura e Natureza. Pavilhão do Brasil na Expo 70. In: PIÑÓN, H. Paulo Mendes da Rocha. São Paulo, Romano Guerra, 2002, p. 39.
} 


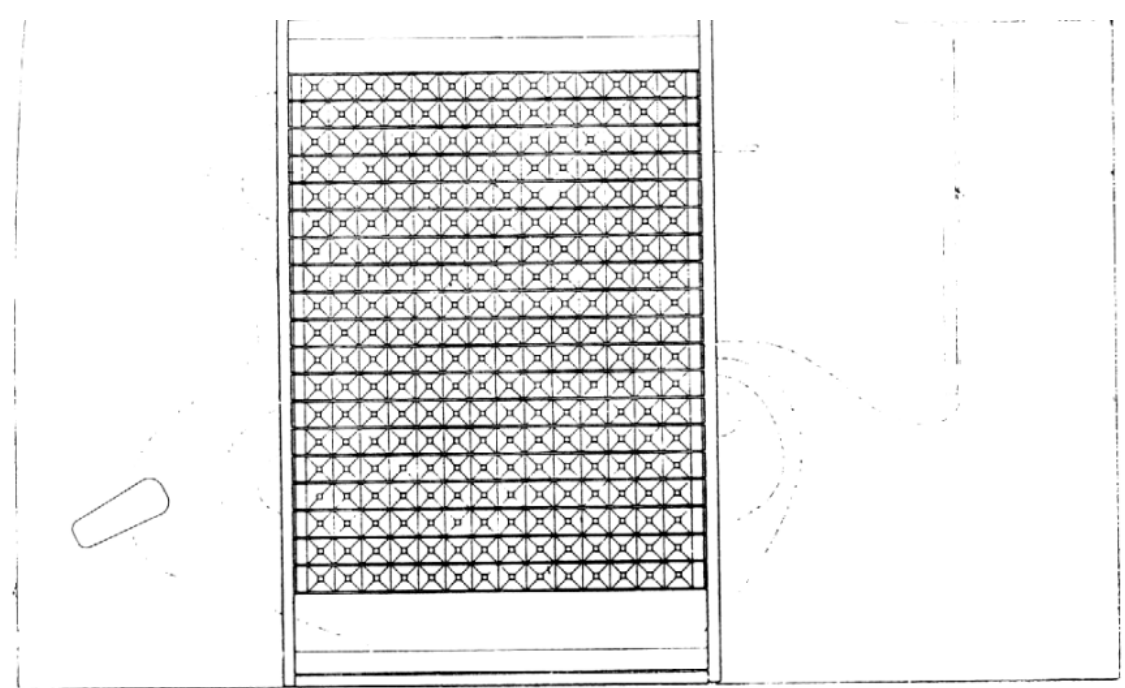

Planta da cobertura

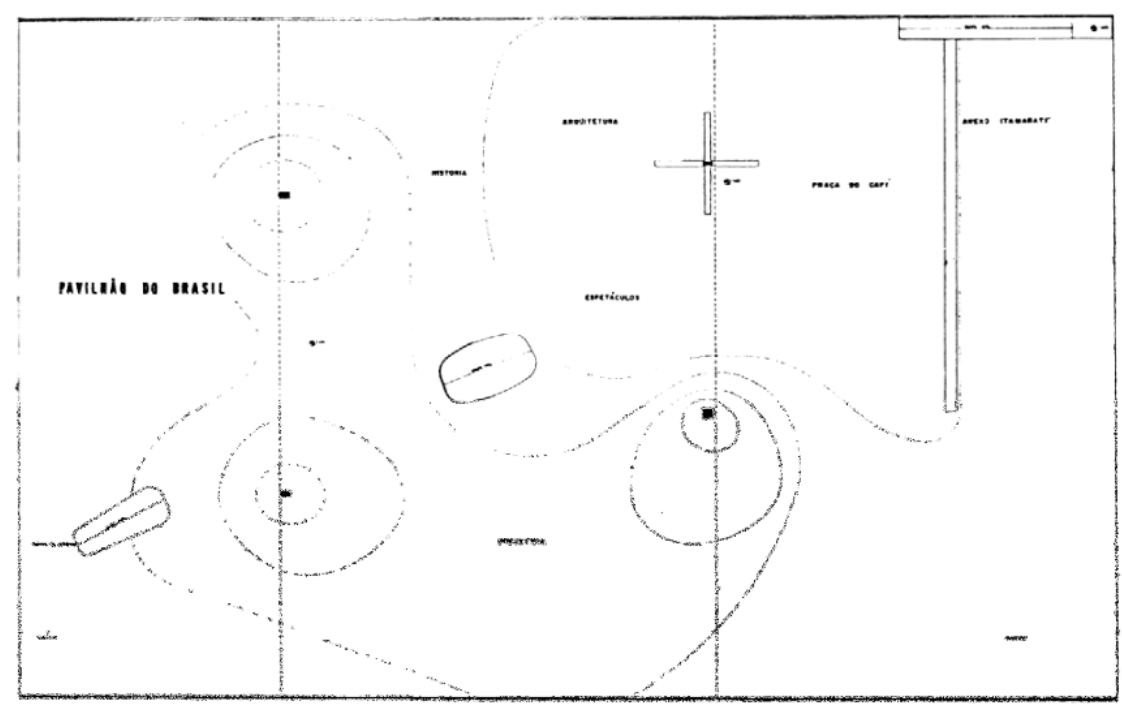

Punter na conter +3.50

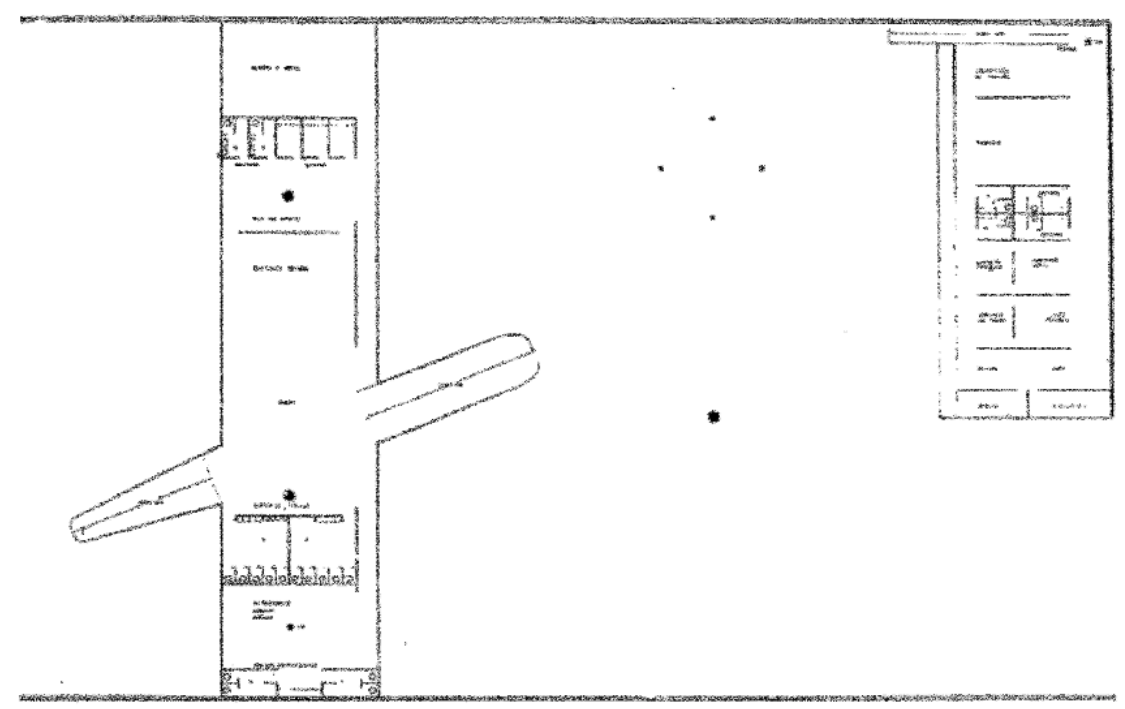

Plantel na cota $=1,50$

Figura 56 - Pavilhão do Brasil para a Expo' 70 de Osaka, 1969-70, plantas. Fonte: Rocha (1969, p. 16). 

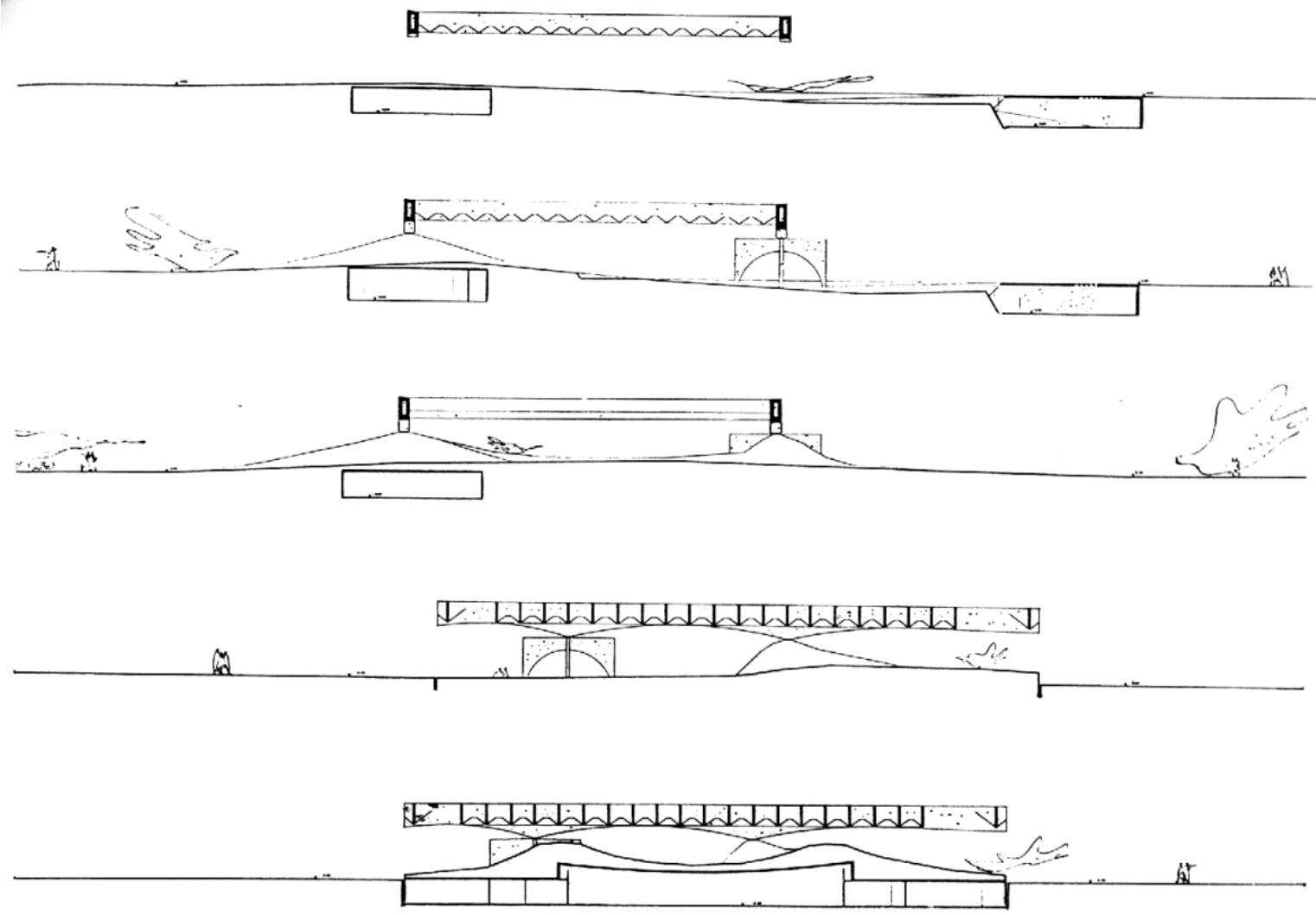

Cortes longitudinais e transversais

Figura 57 - Pavilhão do Brasil para a Expo’ 70 de Osaka, 1969-70, cortes. Fonte: Rocha (1969, p. 17).

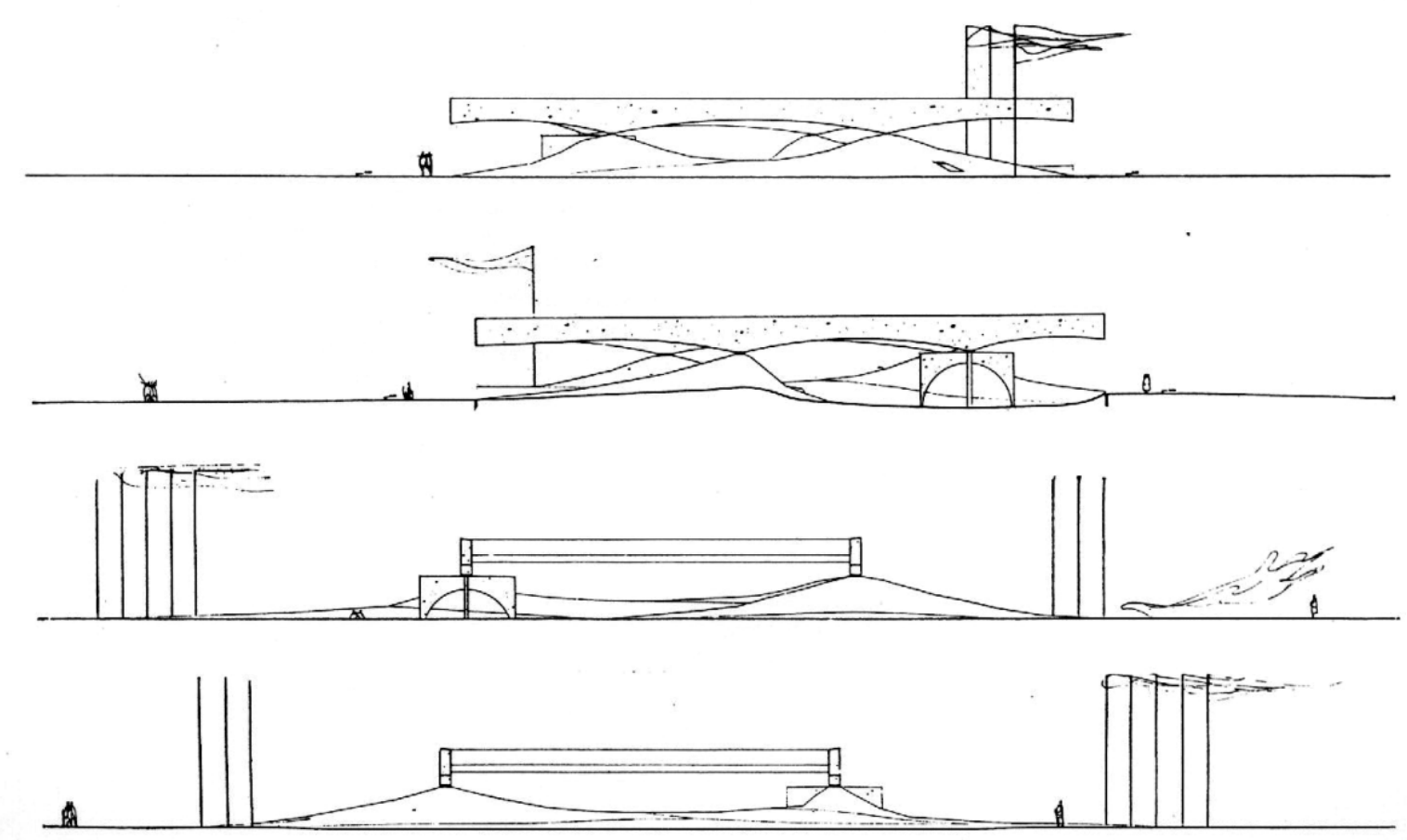

Figura 58 - Pavilhão do Brasil para a Expo’ 70 de Osaka, 1969-70, elevações. Fonte: Rocha (1969, p. 14). 

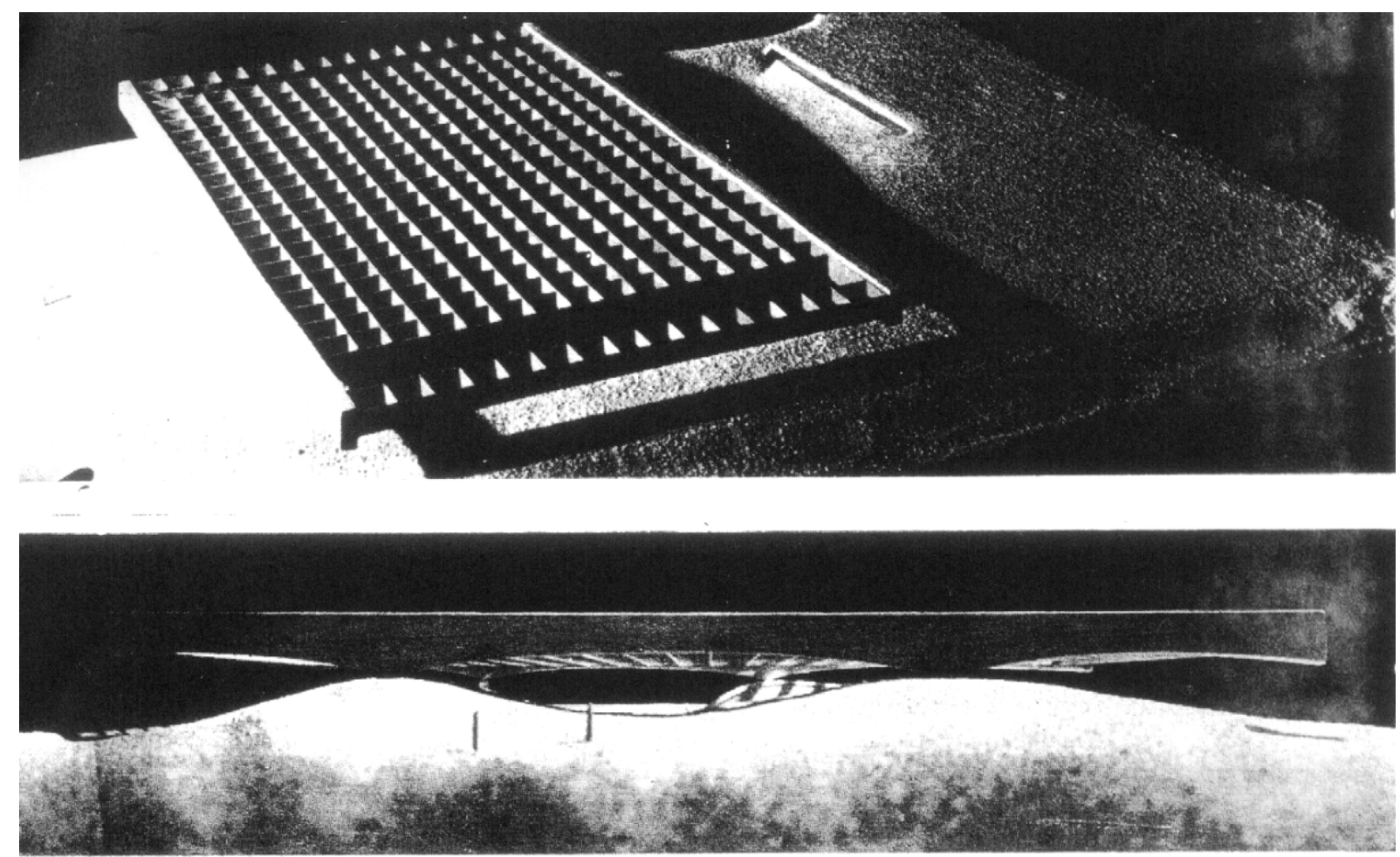

Figura 59 e 60 - Pavilhão do Brasil para a Expo’ 70 de Osaka, 1969-70, maquete. Fonte: Rocha (1969, p. 14).
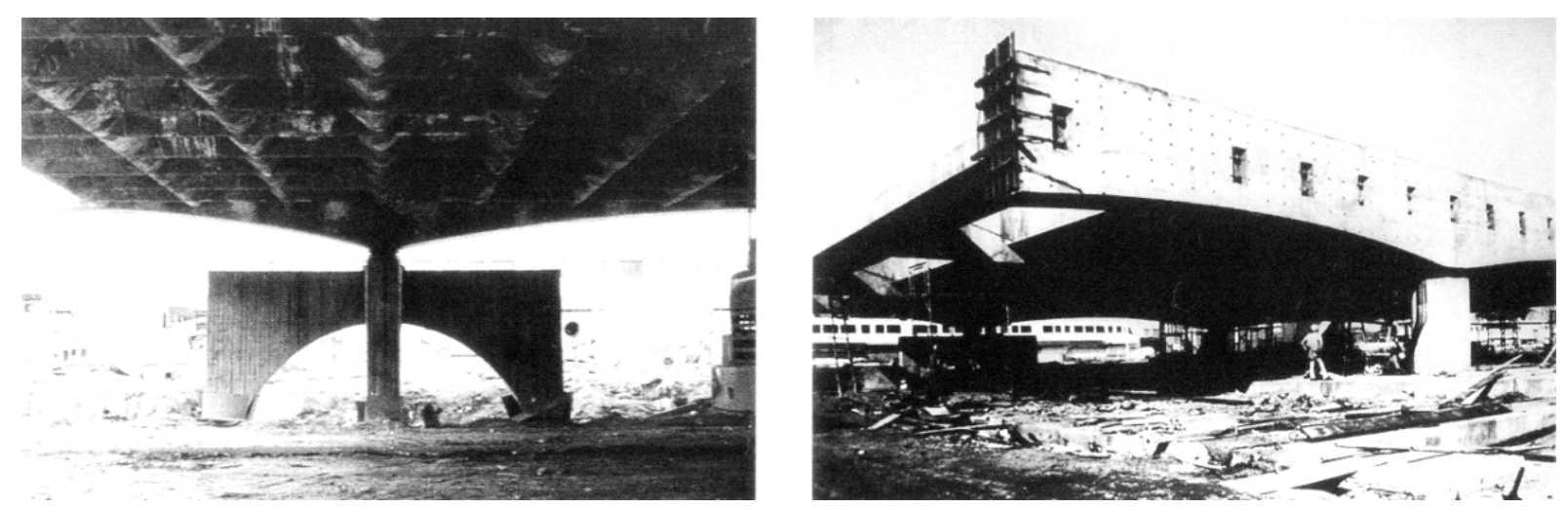

Figura 61 e 62 - Pavilhão do Brasil para a Expo’ 70 de Osaka, 1969-70. Fonte: Artigas, R. (2002, p. 78).
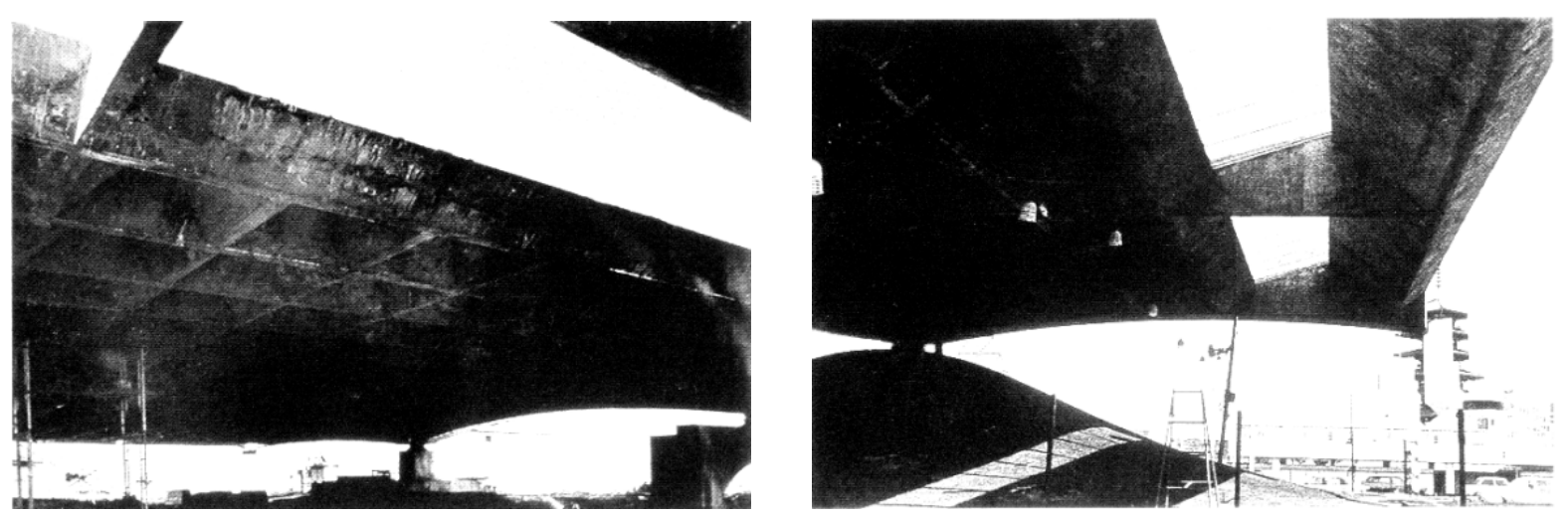

Figura 63 e 64 - Pavilhão do Brasil para a Expo’ 70 de Osaka, 1969-70. Fonte: Artigas, R. (2002, p. 79). 
Nesse sentido, de acordo com Mendes da Rocha, o encontro entre "humanismo e técnica, entre filosofia e matemática, entre razão e imaginação" é o que possibilita uma "visão crítica" por ele apreendida de Artigas. De tal maneira, seu trabalho reafirma uma capacidade técnico-criativa, contudo, perde de vista o embate para modificar a realidade da nação, evocando assim, uma "[...] habilidade do homem em transformar o lugar que habita, com fundamental interesse social, através de uma visão aberta, voltada para o futuro". ${ }^{64}$

Desse modo, embora Mendes da Rocha acredite que uma ampliação no campo do conhecimento possa nos levar para um outro rumo que não o da catástrofe social, as suas posições políticas não se supõem como alternativas para tanto. Nesse caso, antes de uma efetiva transformação da cidade, o arquiteto a aceita como se apresenta. Assim, para Mendes da Rocha, o domínio da técnica funciona mais como uma espécie de "premeditação", como um comprometimento que mantém as "esperanças", mesmo diante da miséria do país. Sendo assim, o trabalho do arquiteto se detém na busca das relações primordiais implícitas no próprio ato de edificar, enquanto passa a questionar a idéia de "progresso". ${ }^{65}$

Nesse âmbito, o desenvolvimento como fruto do progresso, via industrialização, sofre, politicamente, uma brusca inversão, pois a técnica passa a ser lida por Mendes da Rocha como um saber que se perpetua através dos tempos, capaz então de reconfigurar o "território" e a "natureza", independentemente das "dificuldades" e das "angustias" da condição sócioeconômica. Nessa perspectiva, Mendes da Rocha, desloca a pré-destinação da técnica em

\footnotetext{
${ }^{64}$ ROCHA, P. M. da. Genealogia da Imaginação. In: ARTIGAS, R. (Org.). Paulo Mendes da Rocha. São Paulo, Cosac Naify, 2000, p. 72.

${ }^{65}$ ROCHA, P. M. da. Depoimento. A Construção São Paulo, São Paulo, n. 1321, p. 35-36, jun. 1973, p. 35. “[...] Se nós - a população - pudéssemos empregar a palavra progresso para uma cidade, teríamos que dizer que progredir é começar a ter poder de decisão sobre a cidade".
} 
promover as mudanças estruturais da sociedade para uma esfera de “[...] dimensão universal da presença do homem na natureza". 66

Nessa medida, no projeto da casa Mário Masetti (1968-70), localizado no bairro do Pacaembu, em São Paulo, o arquiteto mantém afinidade com o entorno, endo-o sob uma condição territorial. Tal como na residência Butantã, o corpo da casa Mário Masetti está compactado em uma caixa de concreto elevada a 2,10 metros do chão. Acessível por duas escadas laterais que desembocam em uma varanda coberta por vidros, essa massa edificada organiza as funções da habitação, sendo sustentada por quatro tubulões. Tal consecução técnica possibilita a constituição de uma fresta, passível de entrever a "geografia" do lugar.

É por ela que se pretende descortinar a paisagem do vale do Pacaembu e a praça do estádio, tendo a topografia em declive como aliada nessa proposição. Desse modo, o piso de asfalto que avança pela extensão do lote e o plano da grande cobertura que se descola do terreno possibilitam um encontro entre a casa e a cidade. Todavia, embora essa relação retome uma discussão já feita por Artigas, o edifício em questão não tem a pretensão de constituir um solo comum para o espaço urbano (ou vice-versa), nem está apto a desfazer uma polarização entre ambos.

Desse ângulo, nos argumentos de Mendes da Rocha, arquitetura e urbanismo se conversam mediante um “caráter poético", exibindo uma ligação no campo da linguagem, como uma espécie de "projeção" para uma "visão desejada para a cidade", sem que isso implique em uma política combativa. Por esse motivo, apesar do projeto da casa Mário Masetti possibilitar uma continuidade entre os espaços coletivos e os individuais, a cidade

\footnotetext{
${ }^{66}$ ROCHA, P. M. da. A cidade para todos. In: ARTIGAS, R. (Org.). Paulo Mendes da Rocha. São Paulo, Cosac Naify, 2000, p. 172. "[...] Para mim, a primeira e primordial arquitetura é a geografia. Antes de construir o homem escolheu um lugar, onde antevê uma situação arquitetônica sobre o espaço: aqui fundaremos uma cidade, neste estuário será um porto. A idéia de projeção desse universo, das instalações humanas, implica na idéia de construção a partir da configuração inicial que está na geografia e sua necessária transformação.”
} 
permanece como um "chão de passagem", enquanto a habitação continuará como um engenhoso ninho.

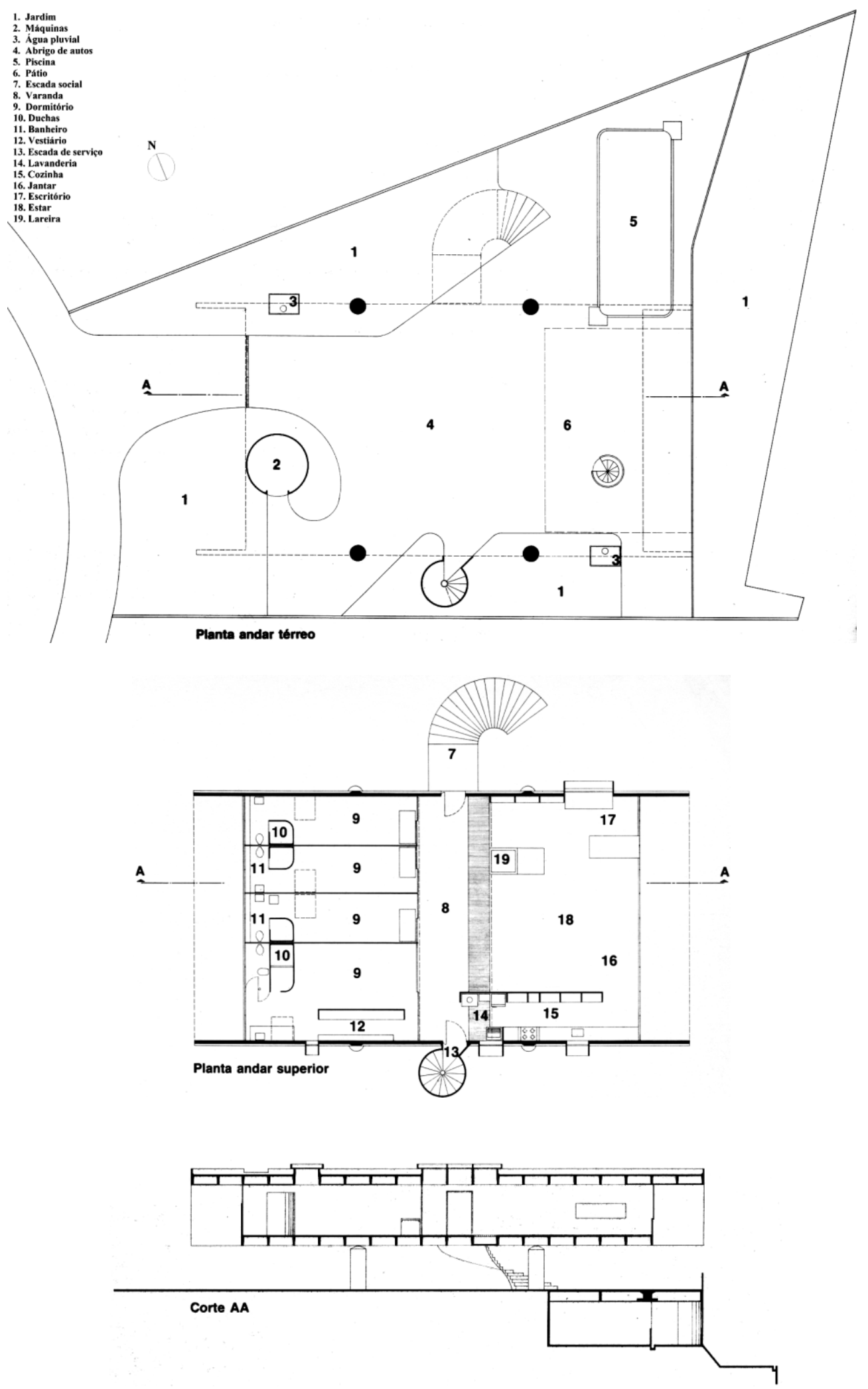

Figura 65 - Casa Mário Masetti, 1968-70, projeto. Fonte: Acayaba (1986, p. 288, 289, 290). 


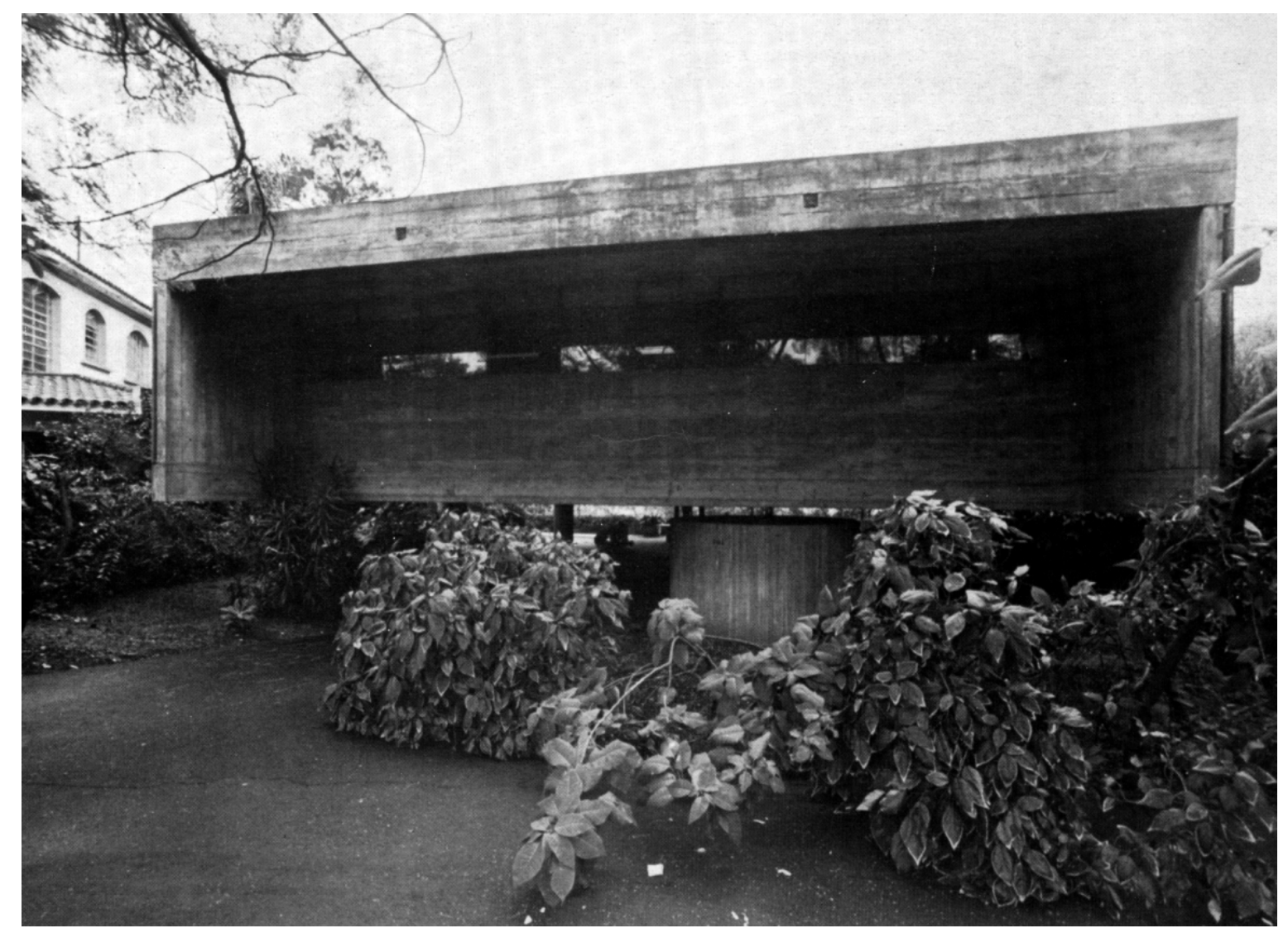

Figura 66 - Casa Mário Masetti, 1968-70, exterior. Fonte: Acayaba (1986, p. 285).

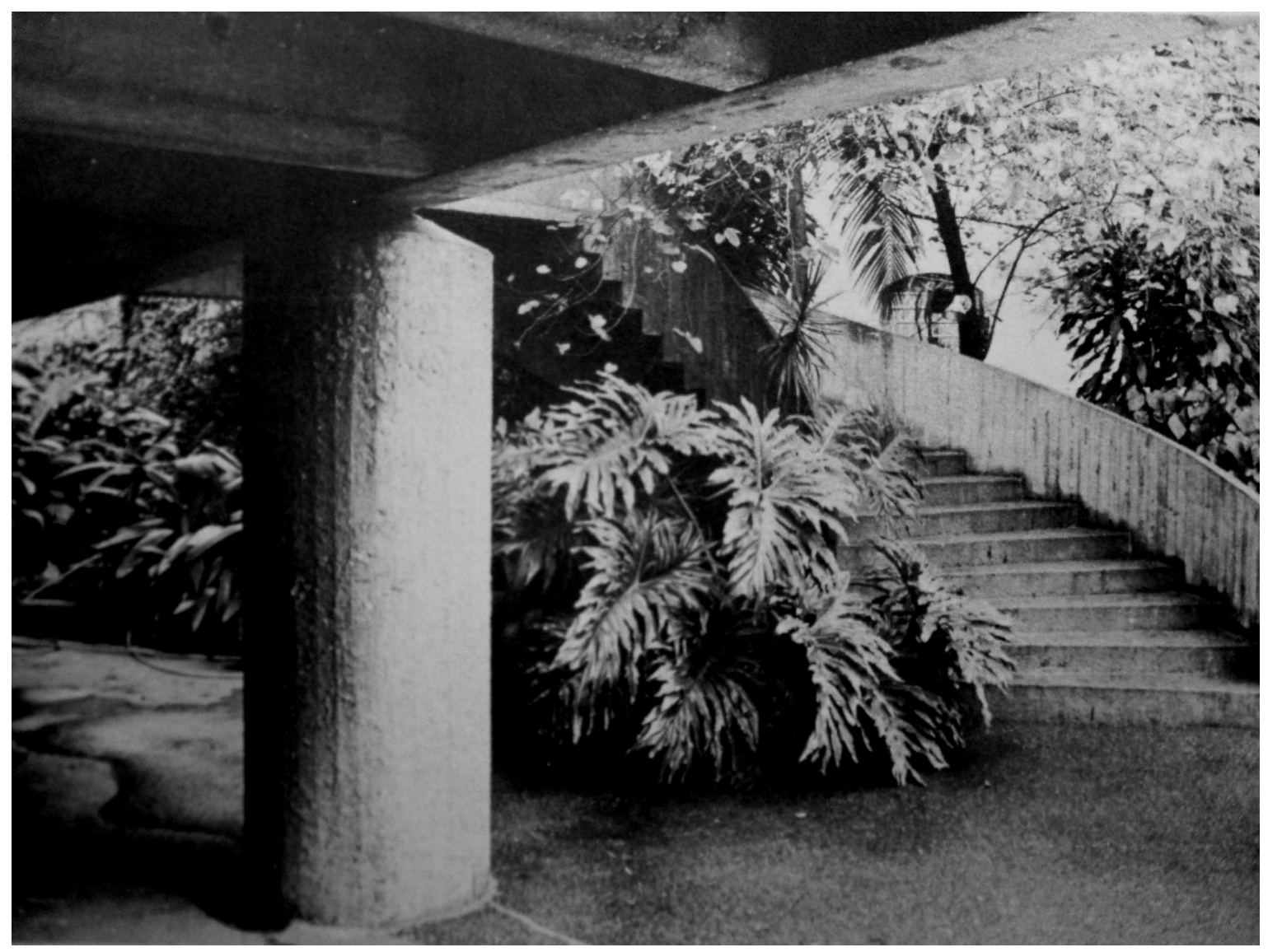

Figura 67 - Casa Mário Masetti, 1968-70, detalhe. Fonte: Acayaba (1986, p. 291). 
Nesse sentido, a casa Fernando Millan (1970-74) erguida em frente ao bosque do Morumbi, em São Paulo, criada por Mendes da Rocha, pode se traduzir como um emblema dessa alegação, já que o terreno foi escavado para que a residência se imbricasse em sua topografia. Dessa maneira, a técnica do concreto armado plasma sítio e habitação como uma unidade. Entretanto, esta menção não faz referência à concretude do bloco único como em Artigas, mas à morfologia do próprio solo urbano, como sugere Castral (1998).

Na casa Fernando Millan, não há mais as quatro colunas de sustentação, como na casa Martirani e, assim, os muros de concreto armado do primeiro piso são constituídos de forma livre, mas funcionam como a ancoragem do resto da construção. Nesse caso, conformam o total fechamento do espaço, na medida em que a cozinha não tem janelas e o centro da residência, com pé direito duplo, só é iluminado por uma clarabóia de vidro. A sala de estar, circunscrita a esse perímetro, incorpora o asfalto como pavimentação, sem, com isso, ratificar uma continuidade com o exterior ou refutar o "caos" do lado de fora.

$\mathrm{Na}$ verdade, escadas e passarelas unem os dois pavimentos principais e a ala de serviço, no subsolo, configurando um ambiente que pode remeter toda a estrutura da casa Fernando Millan a uma construção encavernada. Os muros ondeados do térreo constroem curvas de nível artificiais que se desdobram e se interconectam às nervuras retilíneas da laje de cobertura. Contudo, essa armadura suplanta a função de cobrir, pois comprime, sobre o concreto armado, um espelho d’água e plantas aquáticas, conjugando a técnica indissociada da natureza reconstruída.

Na casa Fernando Millan, a utilização dos materiais em sua forma mais rude, tais como os vidros temperados apoiados diretamente sobre suas estruturas, os filetes de ferro de uma singela escada helicoidal, o piso de asfalto de todo o conjunto social, o concreto aparente das empenas e do teto jardim, cria uma espacialização que não evoca o desenho mínimo da 
seriação, nem visa a re-educação burguesa, atendo-se à utilização dos recursos como uma apropriação inventiva que busca tirar partido do que temos.
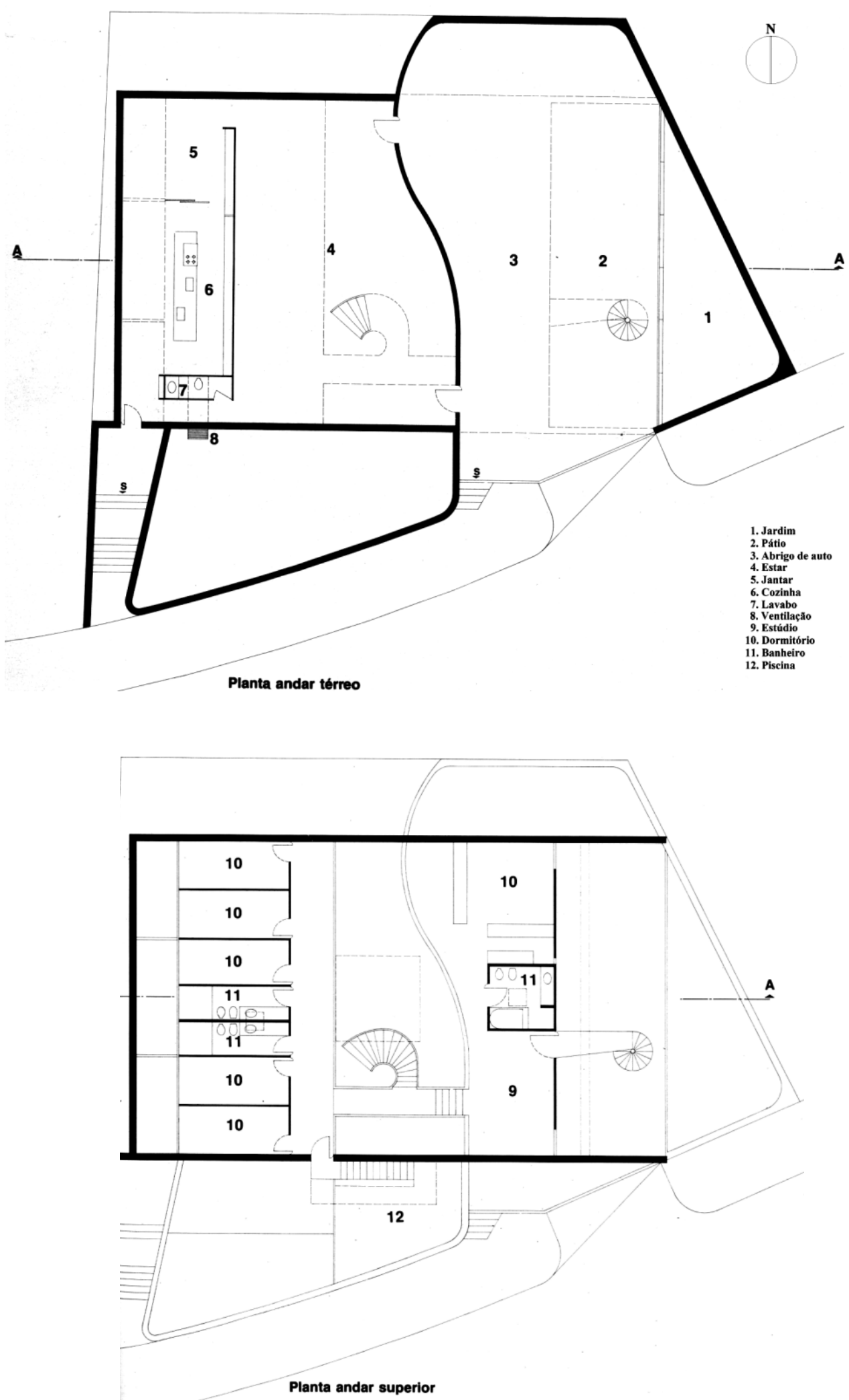

Figura 68 - Casa Fernando Millan, 1970-74, projeto, plantas. Fonte: Acayaba (1986, p. 336, 337). 

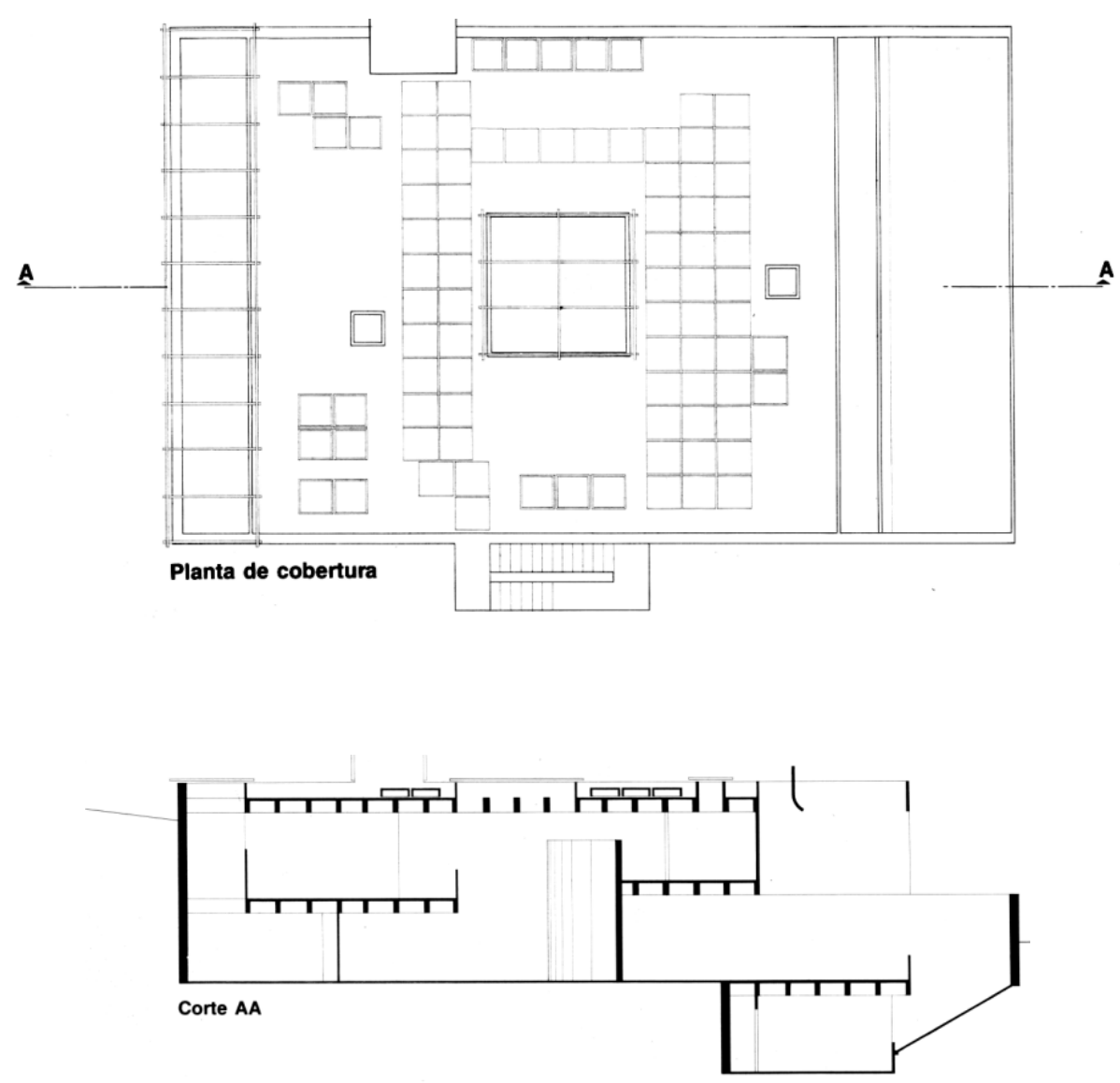

Figura 69 - Casa Fernando Millan, 1970-74, projeto, cobertura e corte. Fonte: Acayaba (1986, p. 338).

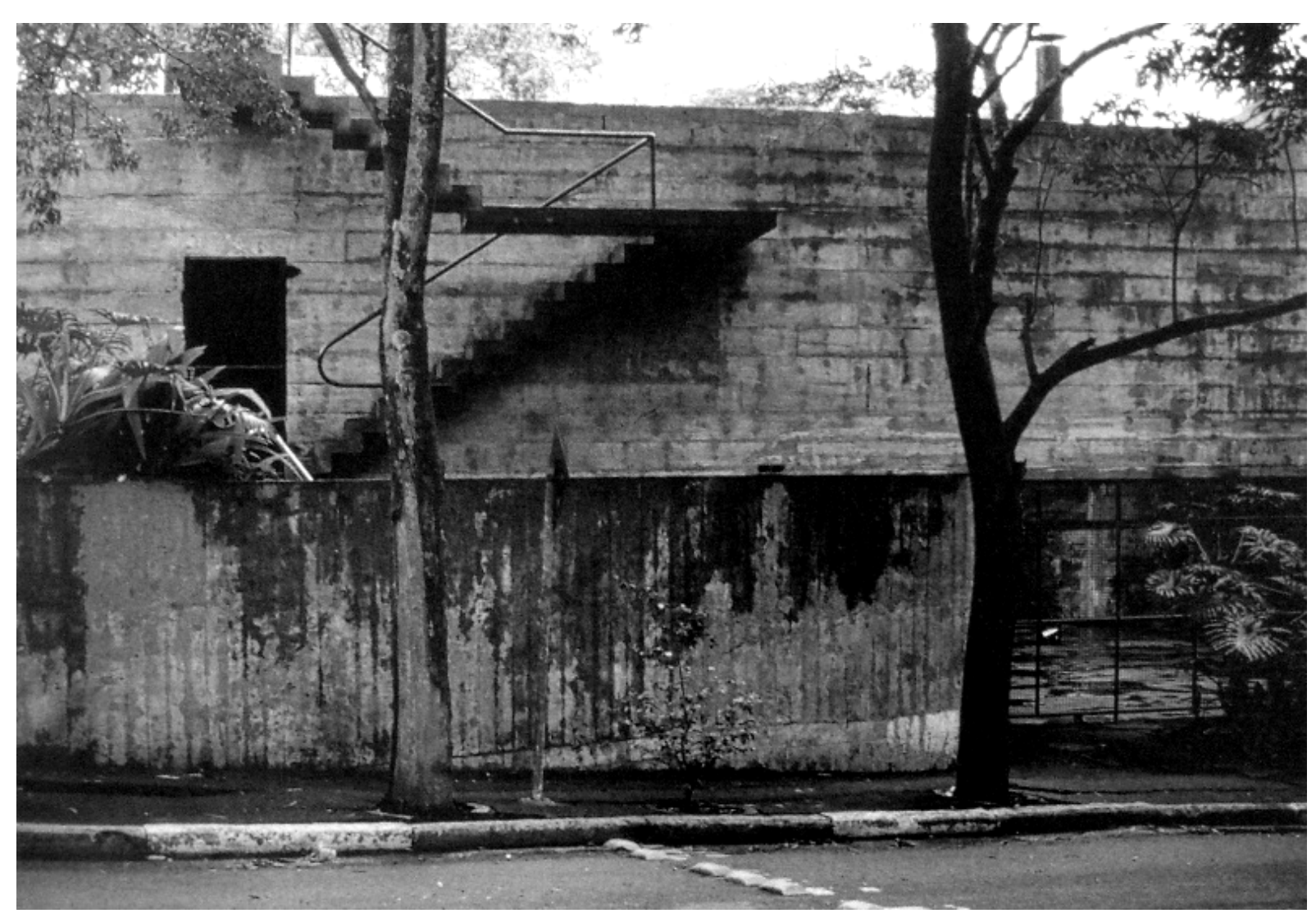

Figura 70 - Casa Fernando Millan, 1970-74, exterior. Fonte: Piñón (2002, p. 153). 

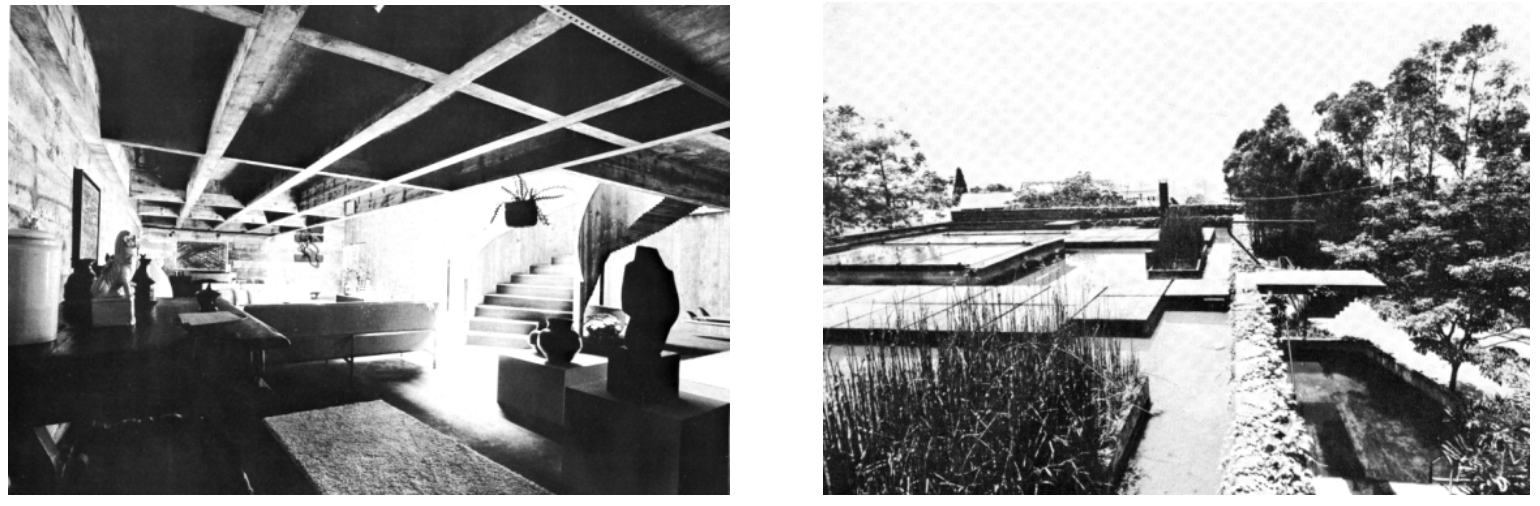

Figura 71 e 72 - Casa Fernando Millan, 1970-74, sala; cobertura. Fonte: Acayaba (1986, p. 333, 342).
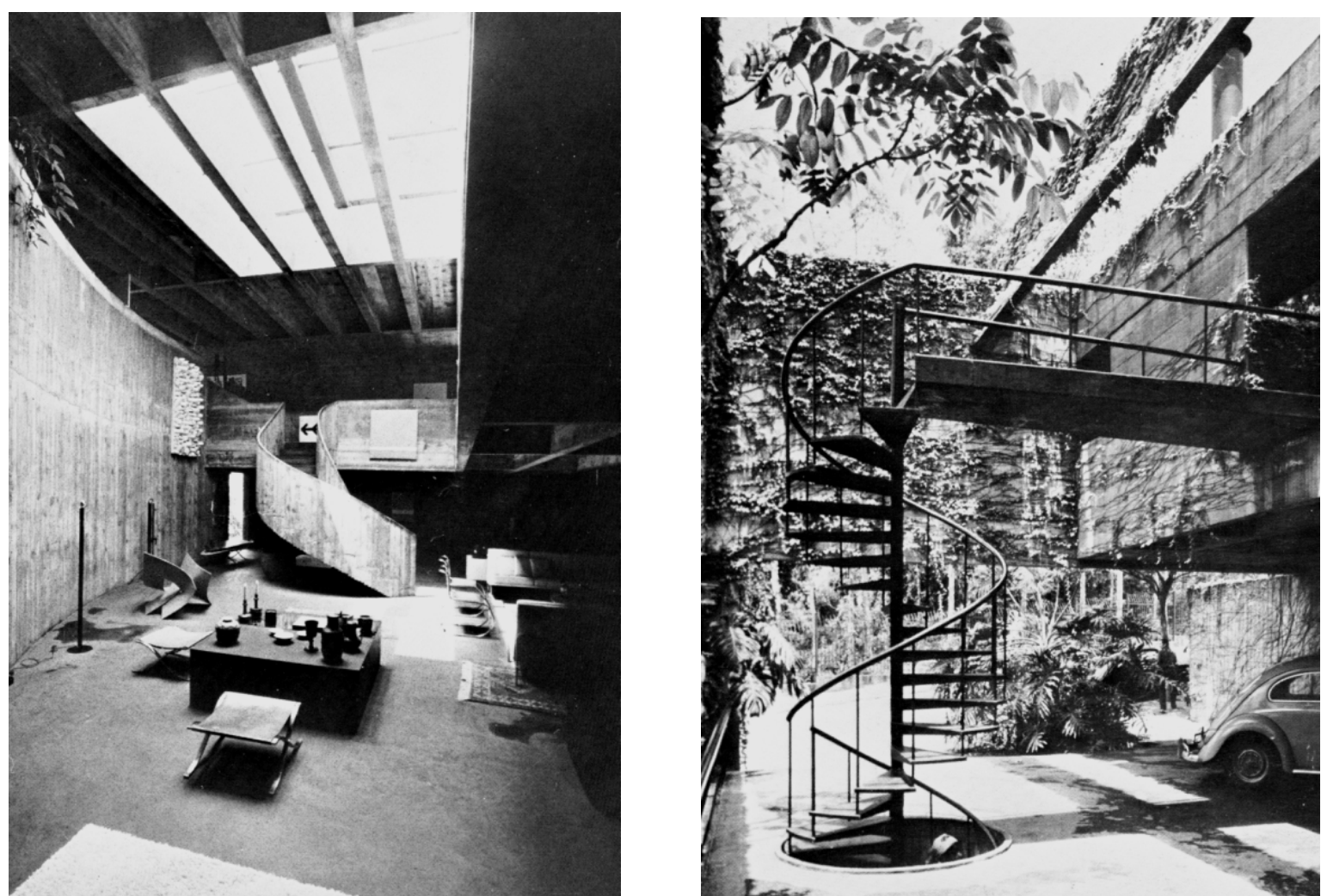

Figura 73 e 74 - Casa Fernando Millan, 1970-74, interior; exterior. Fonte: Acayaba (1986, p. 341, 339).

No entanto, essa experimentação técnico-criativa, cada vez mais, se circunscreve aos trabalhos pontuais. No projeto da casa James King (1972-74), de Mendes da Rocha, isto pode ser lícito, visto que a obra está localizada na Chácara Flora - um bairro residencial fechado, nos arredores de São Paulo. Dessa maneira, enquanto a residência se encapsula sobre os limites da caixa de concreto, por contradição, se lança em um imenso terreno. 
A habitação apoiada sobre oito pilotis resguarda, sob sua grande cobertura de concreto armado, os dormitórios, a cozinha em linha e a sala voltada para um pátio descoberto, mas circunscrito por uma passarela que o limita lateralmente de modo a conformar o bloco suspenso. Entretanto, essa saída não impede a sua permeabilidade. Assim, desvencilhada do tradicional lote urbano paulistano, a casa e a cidade podem se constituir como um continuum. Uma concreção que apenas pode se dar por prescindir da própria realidade urbana.
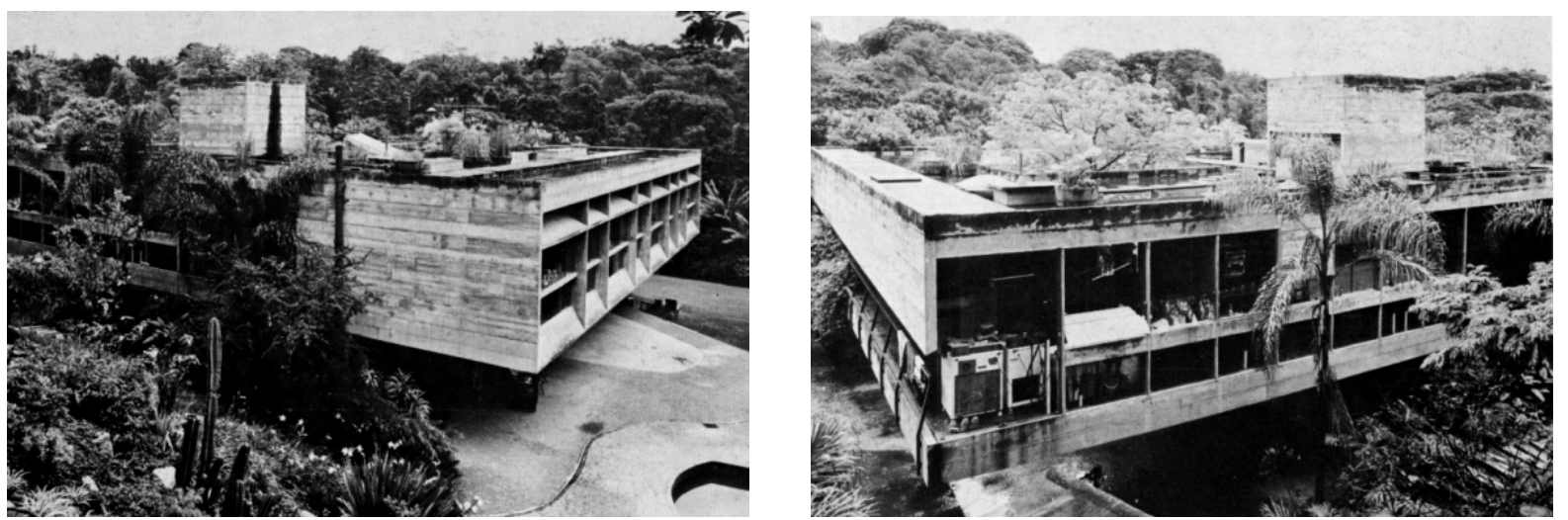

Figura 75 e 76 - Casa James King, 1972-74, exterior e vegetação. Fonte: Acayaba (1986, p. 382).
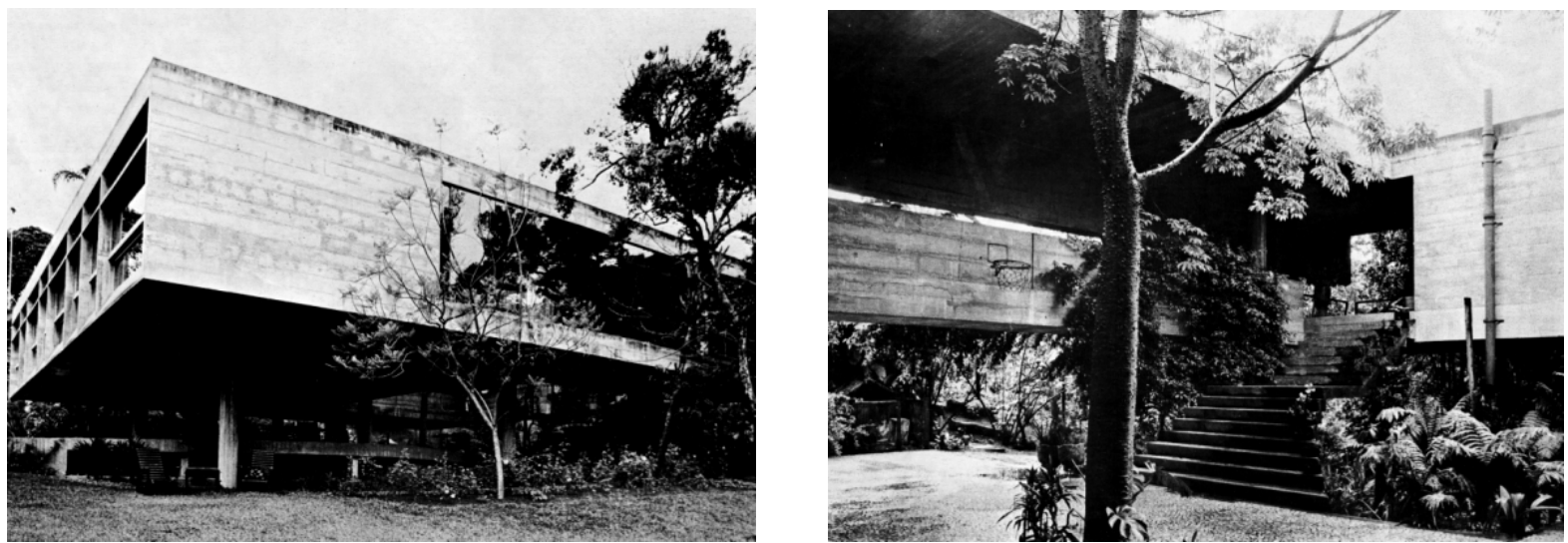

Figura 77 e 78 - Casa James King, 1972-74, exterior e pátio. Fonte: Acayaba (1986, p. 373, 379). 

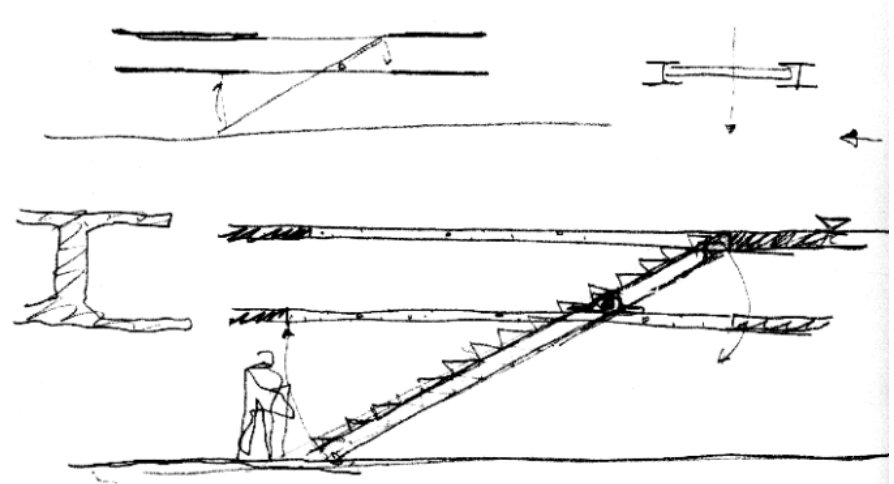

2.3. Castelos da imagem 
No projeto de Paulo Mendes da Rocha para uma casa em Catanduva (1979), cidade no interior de São Paulo, o arquiteto compara a sua busca arquitetônica à tarefa do escultor, cuja urgência em tornar algo "nítido e essencial" se revela "na forma como linguagem". A partir desse propósito, se desvelará a "poética do espaço" de uma "casa atemporal", onde construção, paisagem e cenário se conformam interligados e "a um só tempo". Tal concepção se traduz pela representação de um conjunto formado por casa-piscina-pavilhão, como desdobramento topográfico-arquitetural contínuo, designado como "castelo". 67

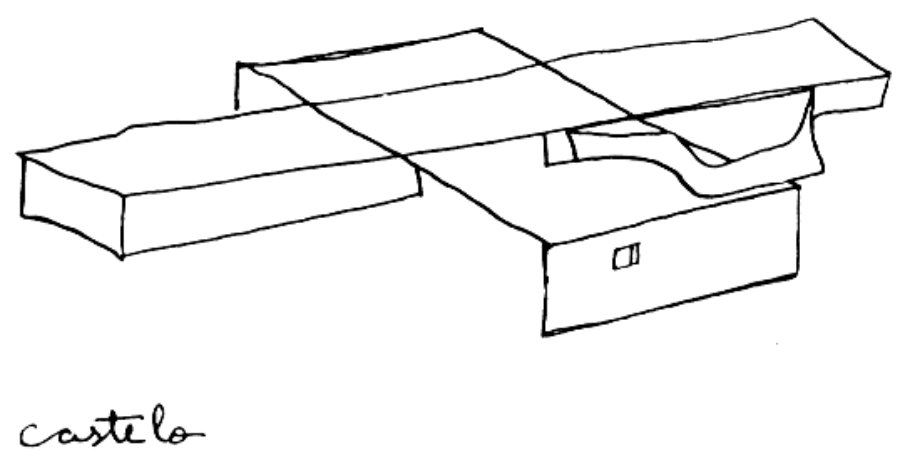

Figura 79 - Casa em Catanduva, 1979, projeto, perspectiva. Fonte: Rocha (1986, p. 32).

Porém, esse conceito pode dizer respeito a um projeto constituído como um castellum (reduto), a casa como uma fortificação, qual uma construção medieval, isolada e independente do resto do território. Noção perturbadora, mas que também espelharia as mudanças ocorridas na cidade contemporânea. A preocupação defensiva junto à função residencial passou a operar como uma característica espacial que não pode ser descartada dentre grande parte das concepções arquitetônicas, sobretudo, no final dos anos 70 - período de estagnação do país e aumento da violência urbana.

\footnotetext{
${ }^{67}$ ROCHA, P. M. da. Casa em Catanduva. $A U$, São Paulo, n. 08, p. 32-33, out./nov. 1986, p. 32.
} 

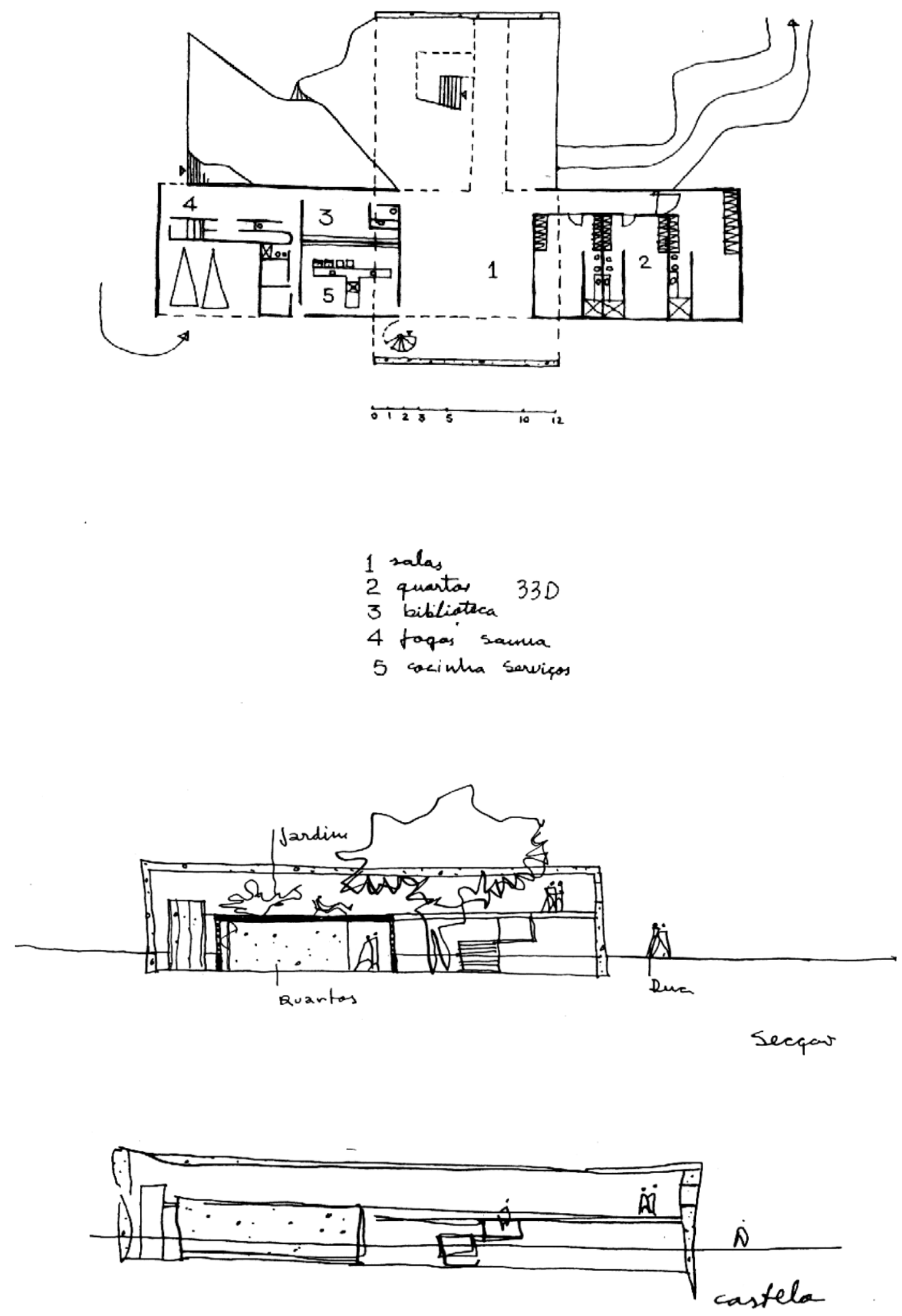

Figura 80 - Casa em Catanduva, 1979, projeto, croquis. Fonte: Rocha (1986, p. 33). 
Dessa maneira, no projeto para a casa em Catanduva, os paralelos possíveis para esse raciocínio tenderiam a ser observados no modo como está organizado, na medida em que a maioria das funções residenciais foi disposta num corpo semi-enterrado denominado "casa", protegido do exterior. Esse bloco poderia ser compreendido como uma espécie de "vallum" (muralha). Além disso, por não ser escavada sob o solo, a "piscina" se configura a partir de um muro em formato amebóide, ladeando a calçada e reforçando uma idéia de barreira.
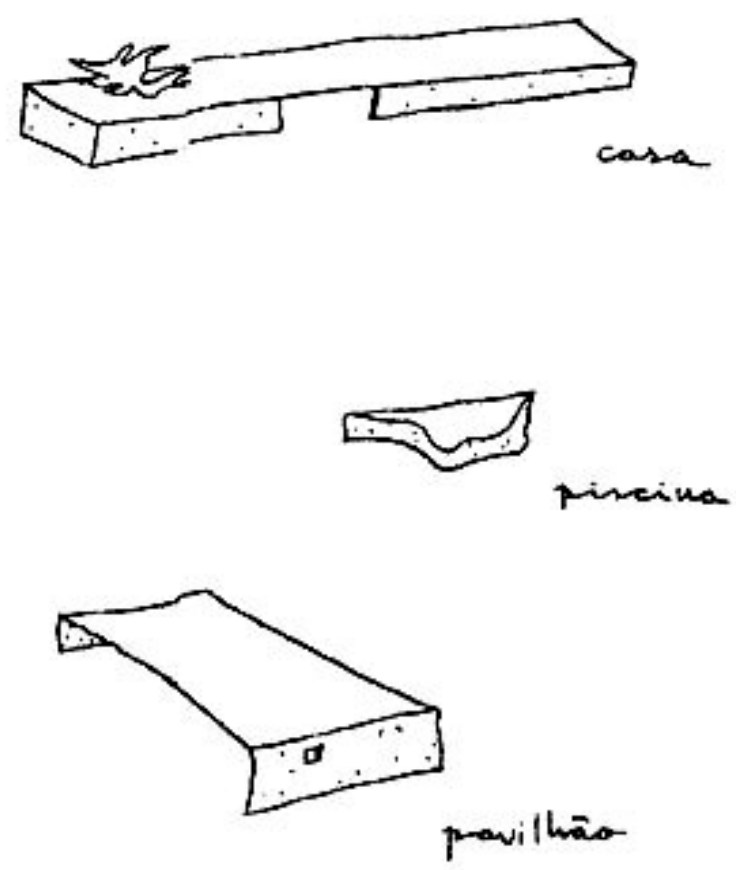

Figura 81 - Casa em Catanduva, 1979, projeto, croquis, unidade tripartida. Fonte: Rocha (1986, p. 33).

No entanto, uma laje longelínea, denominada "pavilhão", se distende sobre a "casa" e a "piscina", desnudando as áreas domésticas e evitando que se confirmem essas aproximações simbólicas. A estrutura, que vai de um lado ao outro do terreno, não condiciona a arquitetura ao cerramento, mesmo porque não conforma elevações vedadas. Pelo contrário, configura uma extensa empena transparente, livre de impedimentos físicos, exibindo os feitos da técnica sem configurar um espaço introspectivo, podendo subverter a política inerente às residências dos anos 50 e 60, erguidas por Artigas. 
Na casa em Catanduva, não está colocada a questão da consecução da grande cobertura como racionalidade vinculada à industrialização da construção, de maneira que a técnica do concreto armado pode agora inverter a idéia de progresso atrelada à sua adesão, durante as últimas décadas, para conformar, na fala de Mendes da Rocha (1986a), “[...] uma casa que pareça muito antiga, para impor sua modernidade". Assim, esse projeto tende a naturalizar um vão de 20 metros, tornando o rigor matemático necessário para sua construção, um domínio já institucionalizado.

Logo, o projeto da casa em Catanduva implica no reconhecimento da nossa realidade, aderindo aos materiais e procedimentos que estão disponíveis para consolidar, no argumento de Mendes da Rocha (1986a), uma residência “[...] como uma nave mágica feita com pedras". Há, nesse intuito, uma consciência sobre o processo que nos mantém reféns de uma obsessão pelo que é novo, mas independentemente de travar confrontos com a lógica de consumo dos nossos dias, a postura tolhida em relação à contemporaneidade tem, como sua redenção, uma perspectiva criativa. Desse ponto de vista, a obra se mantém distante dos conflitos de outrora, enquanto persegue uma "beleza da criação" como condição que está “[...] acima de qualquer ameaça e fragilidade [...]", para assegurar, presentemente, um desígnio que emana da "própria consciência humana". ${ }^{68}$

Deste modo, se as empenas cegas da casa Olga Baeta deflagravam as incongruências da técnica, a casa em Catanduva as admite. Também ao contrário da casa Taques Bitencourt, esse projeto de Mendes da Rocha não se preserva do contato com o exterior. Nessa proposição, a grande cobertura da casa Ivo Vitorito pode ser re-apropriada, contrariando o sentido de interiorização, açambarcando toda a paisagem como consequiência da apologia à licença poética.

\footnotetext{
${ }^{68}$ WOLF, J. Exercício da Modernidade. $A U$, São Paulo, n. 08, p. 26-33, out./nov. 1986, p. 26.
} 
Sob essa condição, apesar da obrigação de "escrever" "projetos numa forma" que seja coerente, o comprometimento com um desenho racional, talvez não se restrinja à concreção de um padrão. Assim, ainda que passível de conseguir uma composição singela, o projeto da casa em Catanduva se reserva o direito de ir além e, portanto, suplantar o imperativo funcional. Essa postura abre caminho para uma prática que se justifica pela "manifestação artística", inerente à "espécie humana", numa ação pré-destinada a "[...] ultrapassar as necessidades de abrigo, de transpor um rio com uma ponte, e fazê-las, essas obras, com formas tais que você conte a sua história”. 69

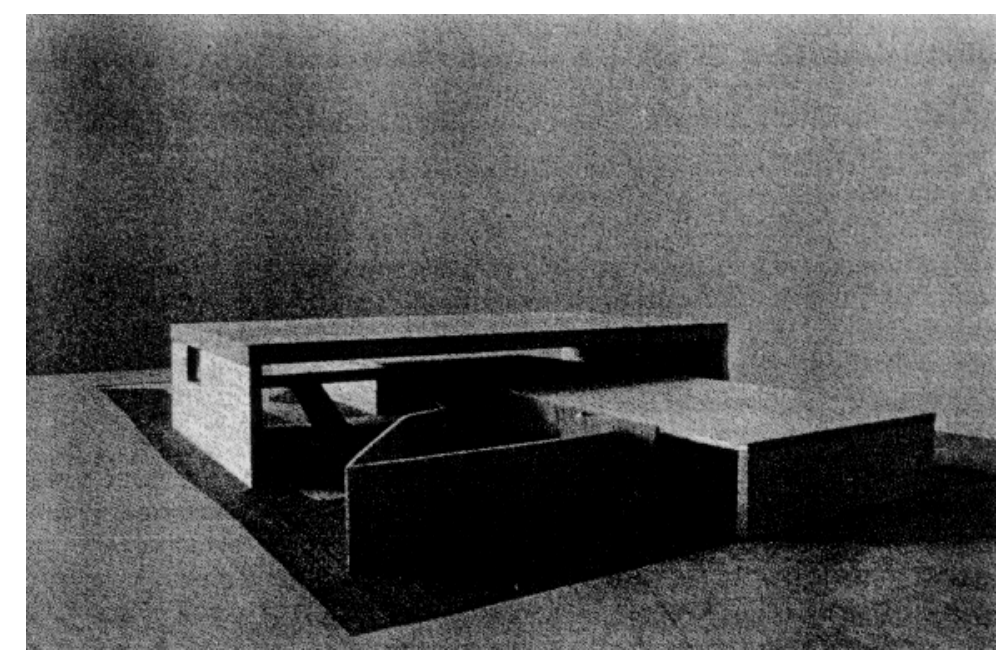

Figura 82 - Casa em Catanduva, 1979, maquete. Fonte: Rocha (1986, p. 32).

$\mathrm{Na}$ verdade, depois da ruína do projeto de progresso econômico e social, o timbre contestatório dos espaços recolhidos da chamada "arquitetura paulista" se arrefece, podendo ser exorcizado e re-trabalhado. Talvez por isso, o projeto da casa em Catanduva se constitua num amplo espaço entreaberto nas áreas comuns, enquanto aqueles destinados à ala íntima estão fechados. Assim, as funções privativas continuarão enclausuradas, mas agora junto à topografia, enquanto a área de lazer e o ambiente social foram escancarados para a rua. Sob essa ótica, o bloco único é tornado uma "unidade tripartida", como diz Mendes da Rocha

\footnotetext{
${ }^{69}$ ROCHA, P. M. da. em entrevista a José Wolf. WOLF, J. Exercício da Modernidade. AU, São Paulo, n. 08, p. 26-33, out./nov. 1986, p. 29.
} 
(1986a), onde as partes se interpenetram no território - vazam pelo lote, pousam sobre o terreno e se arraigam ao sítio.

Tendo saído de cena as políticas de enfrentamento, já que não existe a preocupação de conseguir um protótipo para a economia de meios nem uma ordem urbana a ser deposta, no projeto da casa em Catanduva, pode ter permanecido uma tentativa de desfazer a "divisão" entre arquitetura e urbanismo, apesar dessa intenção somente poder se revelar como uma ambigüidade, visto que, enquanto a massa edificada adensa a construção sobre a terra, a grande cobertura se solta em pleno ar. Uma casa que não prescinde da cidade, nem tampouco a "nega". 70

No “pavilhão", até mesmo uma “janela", enquadrando visuais sobre a grossa empena de concreto armado, sugere relação com o contexto. Assim, existe um exercício crítico na proposição apresentada nos croquis para essa residência do interior paulista, mesmo porque todos da vizinhança poderiam ver parte do que acontece dentro dela, contribuindo para um possível descerramento dos pudores burgueses, pois, na medida em que a "casa" é protegida, também é "devassada" pela grande cobertura que deixa à mostra o seu interior. Porém, ironicamente, esse foi o motivo pelo qual o projeto da casa em Catanduva não foi construído. $^{71}$

Sendo assim, justamente pelo fato do projeto dessa casa se produzir como residência eminentemente burguesa e se pretender aberta, mantém-se amarrada aos dilemas que invalidam a sua própria execução. Os seus croquis conservaram-se como um "castelo" e uma

\footnotetext{
${ }^{70}$ ROCHA, P. M. da. Morar na era Moderna. Projeto, São Paulo, n. 94, p. 99, dez. 1986, p. 99.

${ }^{71}$ O projeto da casa em Catanduva (1979) não foi aprovado pela família de Silvio Antônio Bueno Netto, conforme esclareceu sua esposa Lécia Bueno Netto, por meio do contato que fizemos por ocasião dessa pesquisa. Indagada sobre os motivos desse rechaço, a cliente atribuiu sua decisão ao fato da piscina não se mostrar segura para as crianças, por ser acessada pela cobertura. No entanto, quando insistimos no assunto, a cliente deu ênfase à questão da casa se apresentar "devassada", exibindo a intimidade do lar para a vizinhança. Por isso, a pedido do casal, o arquiteto elaborou uma segunda proposta de residência que foi aprovada depois de quatro meses e demorou quatro anos para ser construída.
} 
outra habitação, totalmente fechada, tomou o seu lugar, erguendo-se como uma imagem postiça dos primeiros desenhos. ${ }^{72}$

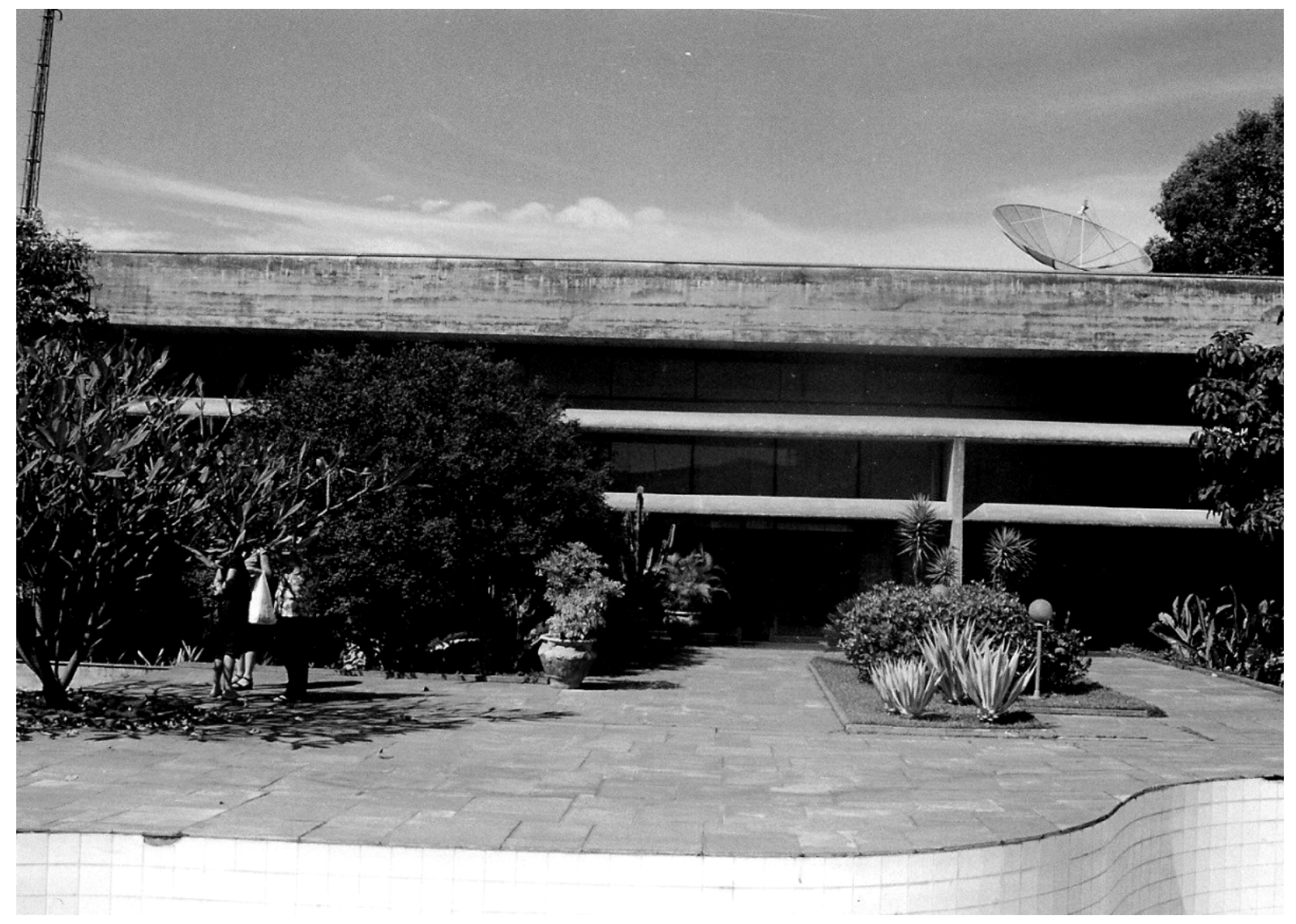

Figura 83 - Casa em Catanduva, 1984 (2. Projeto), vista do pátio interno. Fonte: Soares (2007), foto cedida ao autor.

\footnotetext{
${ }^{72}$ Cabe acrescentar que, quando comparávamos os croquis da casa em Catanduva (1979) com a residência que efetivamente foi construída, pudemos perceber algumas inversões do primeiro projeto para o segundo. $\mathrm{O}$ pavilhão coberto foi mantido, mas alterado de posição e cerrado; o formato da piscina não foi modificado, mas esta foi disposta em um outro nível; e, o mais interessante é que a casa, propriamente dita, foi transformada em uma elevação de concreto para a rua. Nesse caso, restam dúvidas quanto à potencialidade crítica do objeto que ali foi erguido, já que a residência construída em Catanduva, concluída há mais de 25 anos se mostra mais pelo que na verdade esconde: uma grande empena cega na elevação principal; platibandas que recobrem telhas de fibrocimento, que tomaram o lugar da água que inundava a laje, devido a infiltrações; e a piscina desativada por um problema de vazamento, há mais de 9 anos. Cf. SOARES, A. A. Estudo de Caso e Levantamento de Campo - Residência Família Bueno Netto de Paulo Mendes da Rocha - Catanduva-SP. São José do Rio Preto, monografia apresentada à disciplina de Teoria e História do Curso de Arquitetura e Urbanismo da UNIP, 2007. mimeo. Vale ressaltar, que a residência da família Bueno Netto recupera o "padrão" da produção paulista: um bloco totalmente vedado constituindo a sala como um grande pátio coberto. Entretanto, controversamente, a técnica já não revela mais a sua audácia, exatamente pelos problemas que a residência apresenta. Nada mais irônico em se tratando de ratificar um despropósito de alguns princípios modernos inadequadamente apropriados pelo nosso clima, agora retificados pelo que há de ma is arcaico.
} 
Neste caso, poderíamos supor que o próprio desejo de transgressão foi enlaçado pelas imposições das marcas de modernização de um modo de vida cada vez mais hedonista. De tal sorte, a casa que depois foi cons truída no mesmo lote, na cidade de Catanduva, perpetuou um "modelo" na mais pura acepção de um espaço recluso, mas, neste momento, sem promessa ou qualquer denúncia. Assim, o projeto da casa em Catanduva, em nossa percepção, deflagra os impasses do projeto moderno brasileiro, embora sirva como forma de defesa da “[...] luta pela sobrevivência de um fazer". 73

Apesar disso, o projeto para a casa em Catanduva é visto por Telles (1990) como uma espécie de antecipação para o que virá a ser o Museu Brasileiro da Escultura - MuBE (198695), localizado em São Paulo e também concebido por Paulo Mendes da Rocha. Uma obra cuja argúcia admite o concreto armado não apenas como estrutura, mas material "reversível" que é “[...] ao mesmo tempo, laje e cobertura, pilar e empena, interior e exterior”. ${ }^{74}$

Essa acepção explica o museu como construção que se constitui em todas as direções. No entanto, admitimos que dois movimentos dessa síntese espacial sejam os mais relevantes para o entendimento aqui pretendido: o primeiro incorpora a estrutura tornando-a parte do próprio relevo - os compartimentos funcionais -, enquanto um segundo faz aflorar a grande cobertura sustentada por dois pilares-empena, conformando uma armadura solta. Ambos como uma amarração de concreto que é, por contradição, ausência e presença, numa atmosfera indiscernível pela noção de figura e fundo.

\footnotetext{
${ }^{73}$ SPADONI, F. A Transição do Moderno. São Paulo, tese de doutoramento apresentada à FAU-USP, 2003, p. 276. Para justificar a continuidade do moderno, o autor se utiliza dos croquis do projeto da casa em Catanduva. 74 “.... Na casa em Catanduva (não construída), o corpo da construção finalmente se solta, vindo ao chão. Enterrada a meio piso, qual um relevo do próprio chão, a casa prescinde da estrutura. O grande pórtico, transversal à casa, está completamente livre. O museu seria assim uma síntese desse último percurso. Até o momento anterior, a construção em suspenso deixava a superfície buscar o espaço imaginário do horizonte. Agora, esse horizonte próximo, contido pela verticalidade das empenas faz o olhar perder seu ponto de fuga, e o espaço como que se condensa por inteiro a nossa frente. Estamos já dentro do museu. A questão que me parece essencial para compreender seu partido é que só uma certa percepção do concreto armado poderia resolver essa continuidade vertical do projeto [...].” Cf. TELLES, S. S. Museu da Escultura. AU, São Paulo, n. 32, p. 44-51, out./nov. 1990, p. 49.
} 

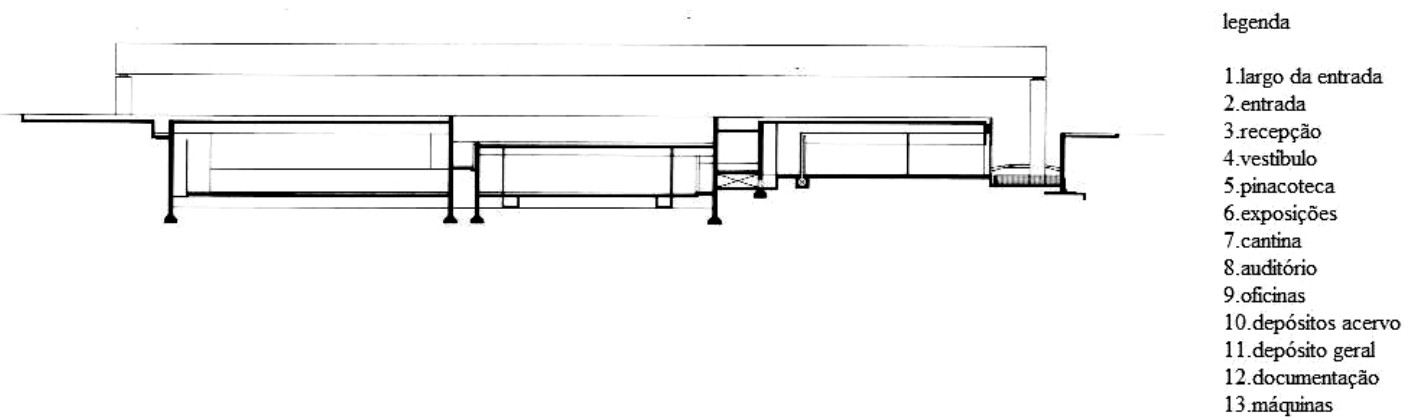

$01 \quad 5 \quad 10 \mathrm{~m}$

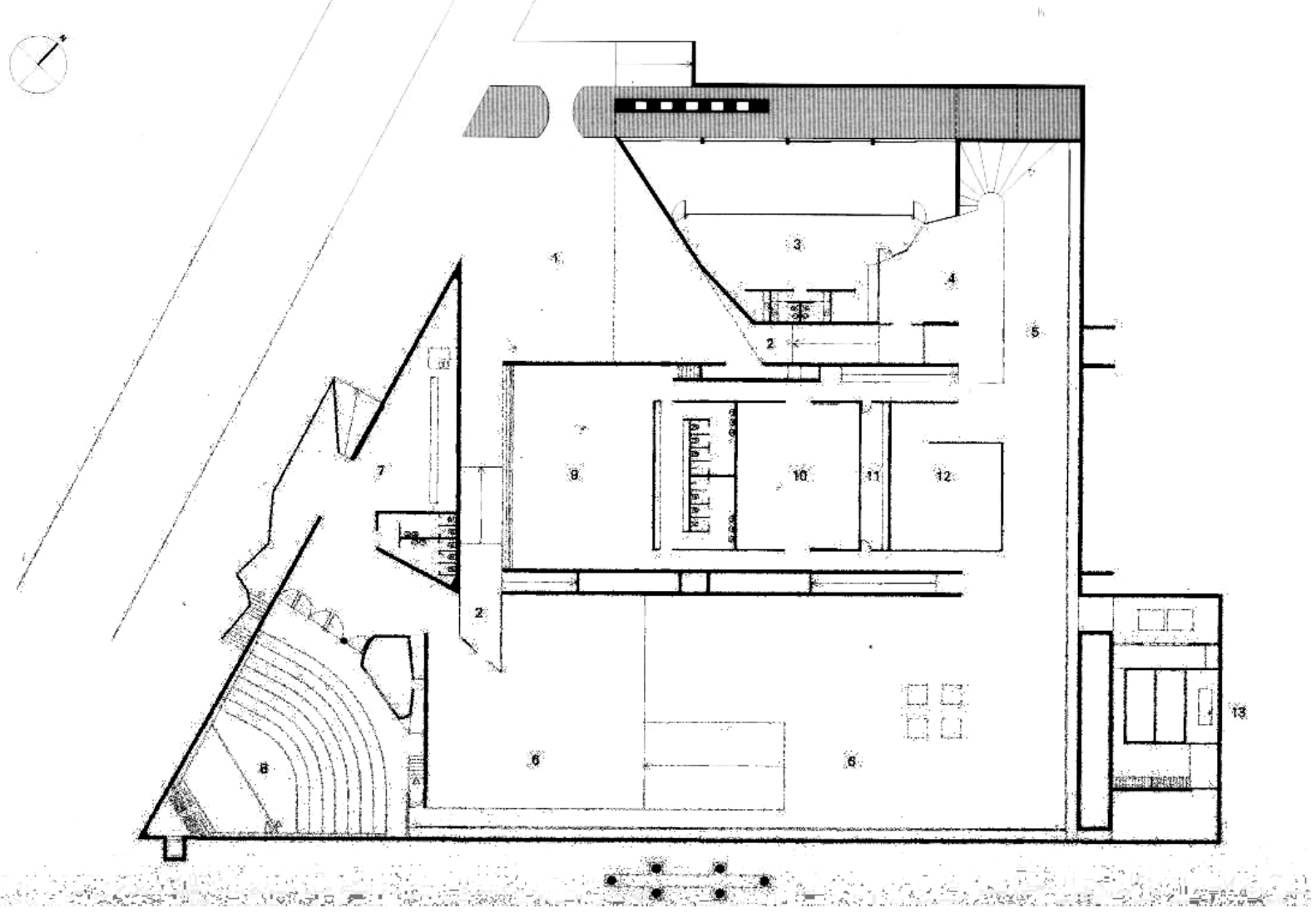

Figura 84 - Museu Brasileiro da Escultura, 1986-95, projeto (1). Fonte: Artigas, R. (2002, p. 89). 


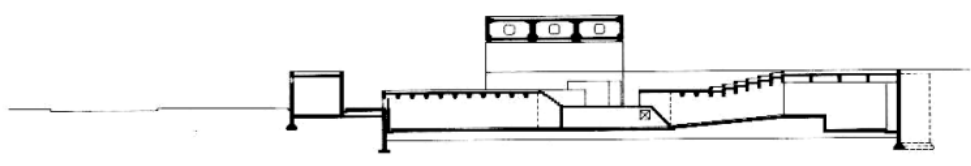

4.espelho đá

5.jardim

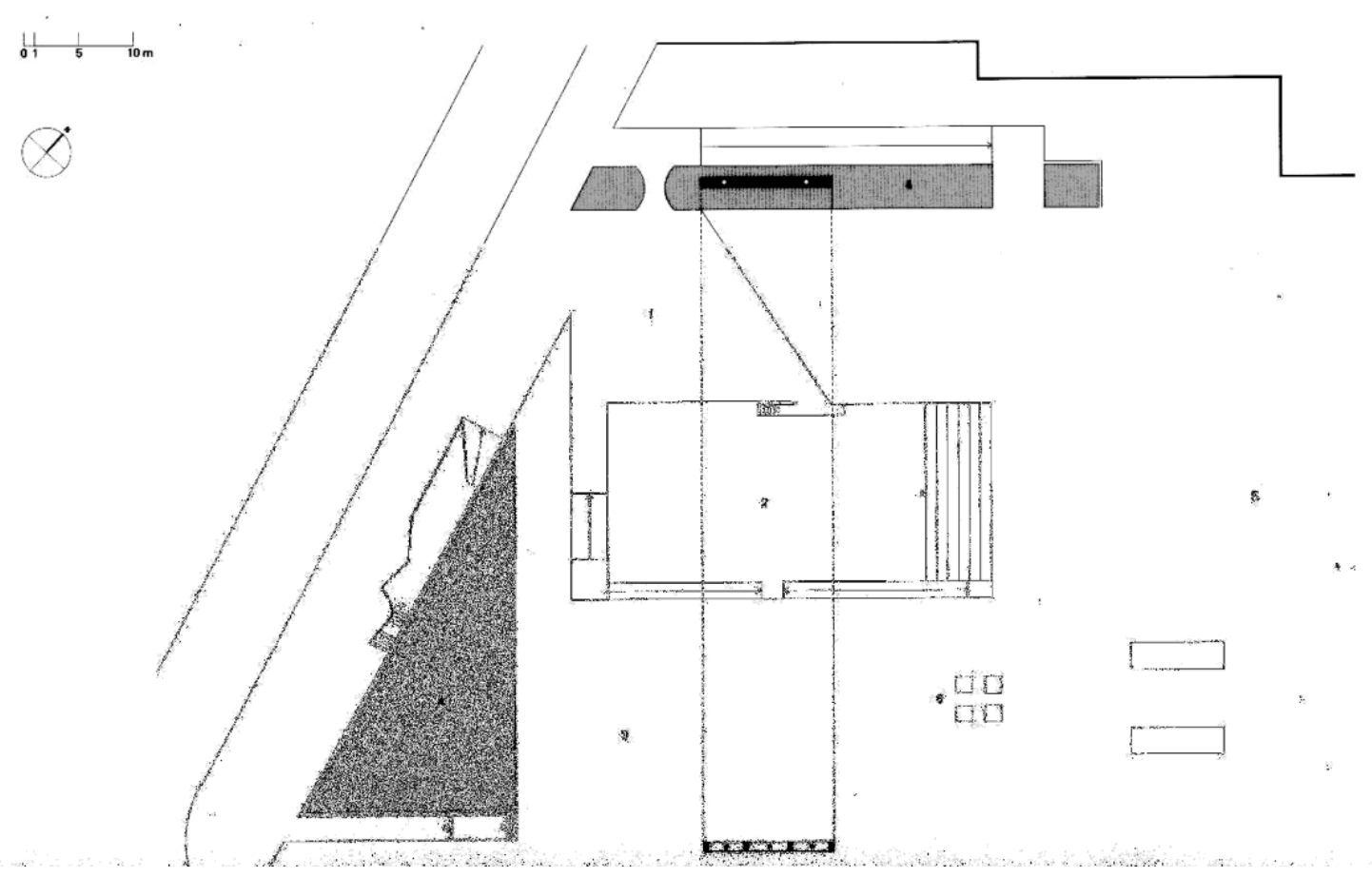

Figura 85 - Museu Brasileiro da Escultura, 1986-95, projeto (2). Fonte: Artigas, R. (2002, p. 88).

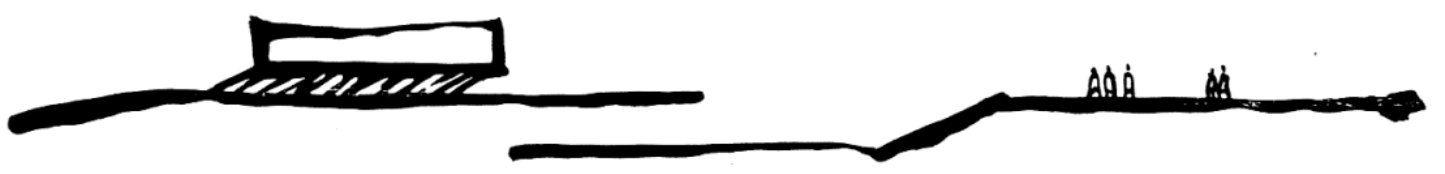

Figura 86 - Museu Brasileiro da Escultura, 1986-95, croquis. Fonte: Artigas, R. (2002, p. 86). 

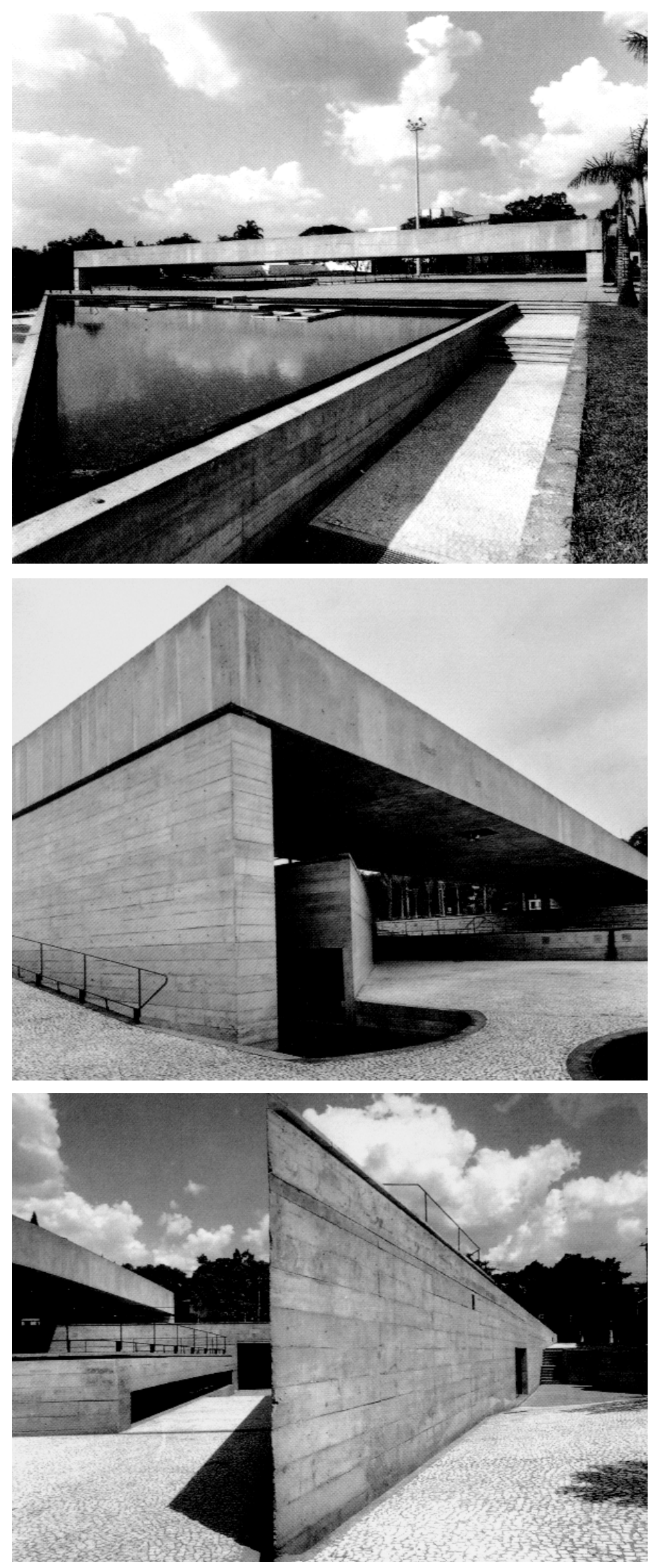

Figura 87, 88, 89 - Museu Brasileiro da Escultura, 1986-95, exterior. Fonte: Artigas, R. (2002, p. 92). 
Nessa imprecisão, dificulta-se a capacidade de decifrar as tradicionais oposições entre os elementos arquitetônicos e, também, entre estes e o urbanismo. Nesse caso, configura-se um conjunto elástico, simultaneamente cerzido e fendido, onde a estrutura se embrenha em um jogo de cheios e vazios, fazendo com que uma percepção da forma arquitetônica implique na apreensão do próprio "território". Sendo assim, o desenho do museu admite a cidade com os seus problemas, ao mesmo tempo em que estabelece "[...] referencias urbanas, visuais e de escala em contrate com seu entorno”, talvez porque “[...] não se atém à noção convencional de um volume sobre um terreno". ${ }^{75}$

Entretanto, ao contrário do prédio da FAU/USP que, no pouso sobre a cidade, aspira um modelo ideal de civilização, o MuBE brota do solo e paira no horizonte sem ter como sua missão a reversão das agruras sociais - apesar do apego à singularidade técnica desse museu seguir o percurso de uma expectativa civilizatória. Assim, o projeto do MuBE pode encadear uma fisionomia arquitetônica que, talvez, refute os exemplos "consagrados" pela chamada "arquitetura paulista" - incluindo a caixa de concreto sobre pilotis. Diante dessa idéia, é possível supor que o caráter projetual presente no MuBE engendre um questionamento sobre uma política arquitetural que se converteu em estética.

Nesse caso, a possibilidade de interrogar a prática recente poderia repelir o freqüente recurso à originalidade das propostas contemporâneas e ainda extravasar o limite da produção brasileira, contrariando o crescente virtuosismo que passou a povoar o mundo da arquitetura durante os anos 80. Nessa conjectura, se justificaria a importância que Mendes da Rocha dá à técnica que, para Gimenez (1998), assume a caracterização de uma “ancestralidade imanente

\footnotetext{
75 SEGAWA, H. Arquitetura modelando a paisagem. Projeto, São Paulo, n. 183, p. 32-47, mar. 1995, p. 36.
} 
ao procedimento", como uma capacidade de voltar às origens e, assim, "despertar novamente o primordial". 76

As provas desse entendimento podem ser encontradas no próprio discurso de Mendes da Rocha em relação ao MuBE, na maneira como ele o justifica como construção arquetípica que prima por re-introduzir materiais e procedimentos como um desdobramento histórico das ações do homem na natureza. Então, na proposição de Mendes da Rocha, a grande cobertura do MuBE seria, assim, uma "referencia primordial" que poderia aludir os antigos dolmens de "Stone Henge", numa técnica capaz de concatenar a capacidade de "engenho" da humanidade através dos tempos, colocando a "pedra no céu". 77

Contudo, essa ação também enseja uma persistência em afirmar o "engenho" criativo, sem que se possa escapar a uma recorrente demonstração de um grande vão. Nesse caso, em detrimento dos dilemas tecnológicos e a favor de certa interpenetração no seio da metrópole, o projeto para o MuBE busca por uma "horizontal perfeita". Assim, o discurso abonado por um viés humanista acaba por ter, como resultado, a "exibição da possibilidade da técnica". 78

Sob esse ângulo, através da fresta necessária para a dilatação da estrutura porticada, é possível vislumbrar a realidade da cidade, frente a uma apreensão que é continuamente fugaz, aludindo o movimento dos "ônibus passando" pela avenida perpendicular a essa construção, como reitera Mendes da Rocha (2002). Uma condição urbana que, ao invés de revelar uma postura política agressiva, se resguarda ao posicionamento de ser enxergada de soslaio,

\footnotetext{
${ }^{76}$ GIMENEZ, L. E. Autenticidade e Rudimento. AU, São Paulo, n. 79, p. 70-71, ago./set. 1998, p. 70.

77 ROCHA, P. M. da. Criando a referência. Descrição de Hugo M. Segawa. SEGAWA, H. Arquitetura modelando a paisagem. Projeto, São Paulo, n. 183, p. 32-47, mar. 1995, p. 34. Apesar de fazer parte de uma colagem textual, essa expressão foi extraída de um depoimento real de Mendes da Rocha, de acordo com matéria do referido periódico.

${ }^{78}$ ROCHA, P. M. da. Cultura e Natureza. Museu da Escultura - MuBE. In: PIÑÓN, H. Paulo Mendes da Rocha. São Paulo, Romano Guerra, 2002, p. 32.
} 
porque as empenas laterais e todo o conjunto do referido museu funcionam como uma espécie de "caverna", em meio aos contra-sensos que estão por toda a sua volta. ${ }^{79}$

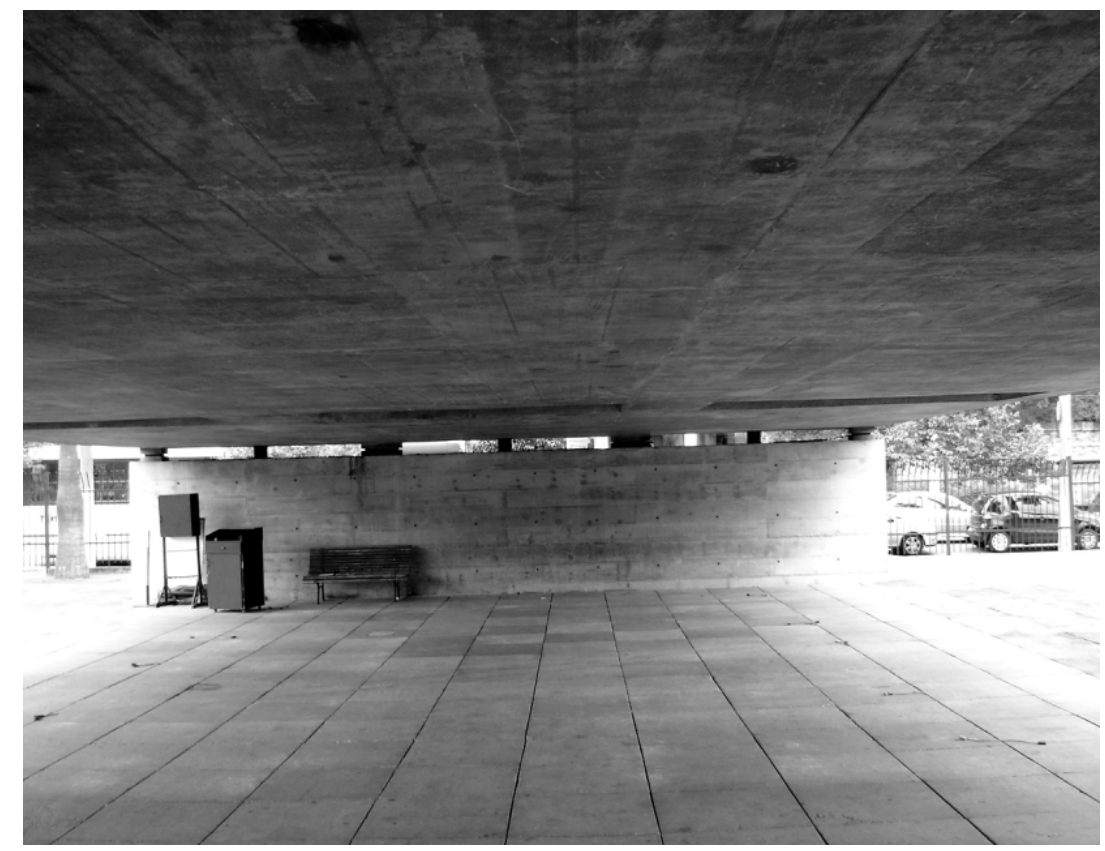

Figura 90 - Museu Brasileiro da Es cultura, 1986-95, fresta da estrutura. Fonte: autor (dez. 2006).

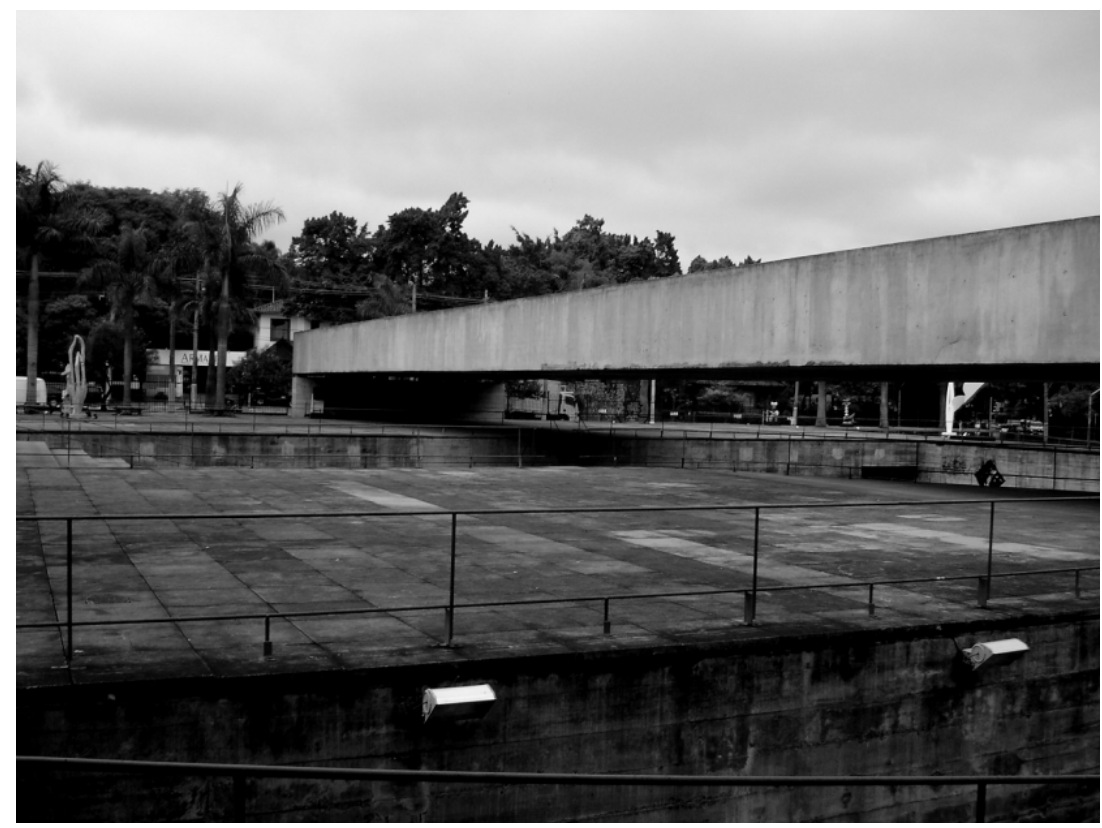

Figura 91 - Museu Brasileiro da Escultura, 1986-95, praça. Fonte: autor (dez. 2006).

${ }^{79}$ COENEN, J. Meus encontros com Paulo Mendes da Rocha. Vitruvius. Disponível em: <http://www.vitruvius.com.br/arquitextos/arq001/arq001_02.asp>. jun. 2000. Acesso em: 01 ago. 2008, p. 02. Quando esse arquiteto trabalha essa idéia, não se contrapõe à postura política de Paulo Mendes da Rocha. 
Diante dessa proposição, não queremos fazer referência às grades que logo depois da construção cercaram o que era um território pensado como um ágora arendtiana, nem mesmo à guarita de vigilância que foi disposta ao lado da extensa laje-viga, mas, sobretudo, a idéia do museu como um exterior que é, por contradição, um interior. Nesse raciocínio, apesar de uma interpenetração visual que podemos ter perante sua superfície, o MuBE tem todos os atributos de um espaço circunscrito. Talvez porque, ao se esquivar das conveniências de mercado, o seu espaço é apropriado para a distinção da própria vizinhança que o construiu.

De certo modo, a intervenção de Mendes da Rocha reinscreve o que, até então, era um lote enviesado no cruzamento da Avenida Europa com a Rua Alemanha, no coração do bairro dos Jardins, em São Paulo, como um espaço restrito às cercanias mais valorizadas da capital paulista, justamente por ter sido idealizado pela Sociedade de Amigos dos Museus - SAM. Uma organização formada por moradores dos bairros da elite paulistana que conseguiu evitar a construção de um shopping center no terreno de 7000 metros quadrados que, em comodato, foi destinado ao museu. ${ }^{80}$

Sob esse ponto de vista, o grande pórtico que conforma a imagem do MuBE é também tornado o signo daquela região. Reflete, nesse sentido, uma simbologia urbana oriunda do nosso atual estado de laissez-faire. Arquitetura que só é possível porque engendra o apetite consumista pela cultura tornada mercadoria, exposta na cidade por meio de um museu que, por entre as esculturas da parte externa e os desfiles de modas que acontecem em seu interior, conduz para a leitura do encastelamento estético e político de um repertório, como os resquícios de um projeto outrora audacioso.

Nessa proposição, os compromissos políticos dos arquitetos se volvem cada vez mais absortos aos mecanismos que promovem seu sucessivo esvaziamento. A Loja Forma (1987),

\footnotetext{
${ }^{80}$ MUSEU Brasileiro da Escultura Marilisa Rathsam. São Paulo, Editora JC, 2001, p. 06.
} 
de Mendes da Rocha, ajuda-nos a discorrer sobre esse paradoxo. Na Avenida Cidade Jardim, em São Paulo, a estrutura desse projeto torna a recuperar uma convenção que pode ser lida em um percurso formal da chamada "arquitetura paulista". Mas, agora, a caixa suspensa não se constrói com empenas cegas, porque o espaço deve ser tratado para que a obra funcione como uma vitrine.

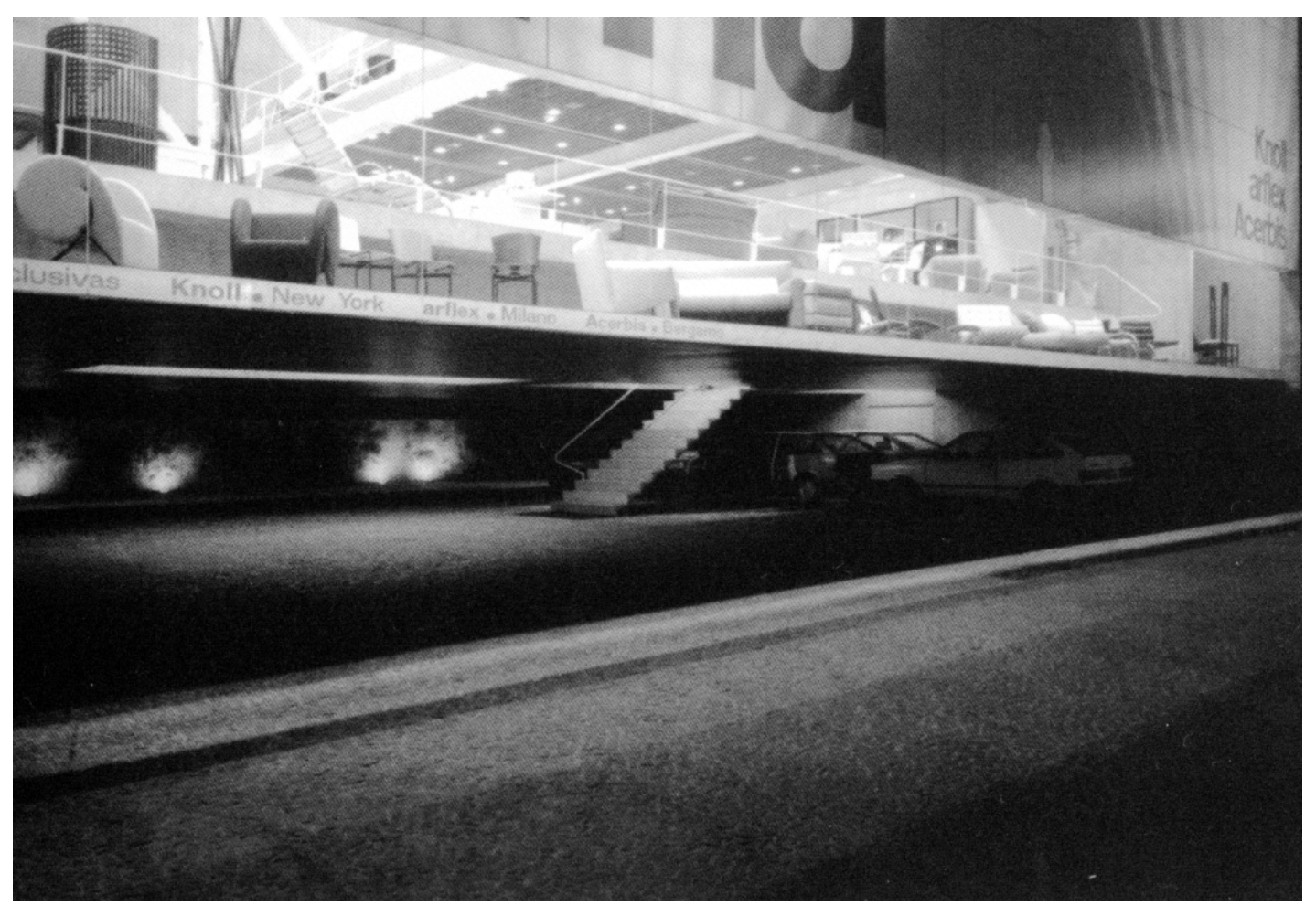

Figura 92 - Loja Forma, 1987, exterior à noite. Fonte: Piñón (2002, p. 75).

A visualidade do interior passa a permear uma conformação do projeto da Loja Forma. Assim, o arquiteto configura o que chama de "dois castelos de apoio" que servem de paredes e pilares de concreto para sustentar a levíssima armação metálica que construirá os 30 metros de vão livre do espaço de vendas. Esses elementos pétreos são, para Mendes da Rocha (2002), uma referência histórica presente na arquitetura há mais de dois séculos e, por conta disso, se incorporam às premissas de um raciocínio estrutural que, antes de convir para a sedução do olhar, servem de ancoragem para que um material mais ligeiro possa parecer alçar vôo. 


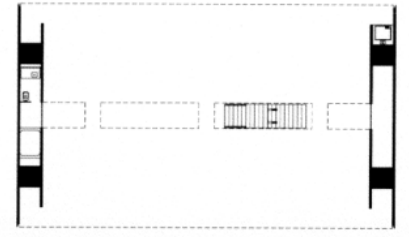

planta do térreo

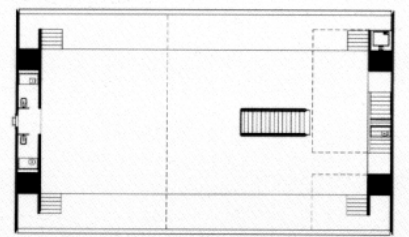

planta do primeiro andar

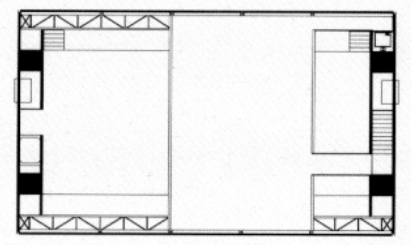

planta do mezanino
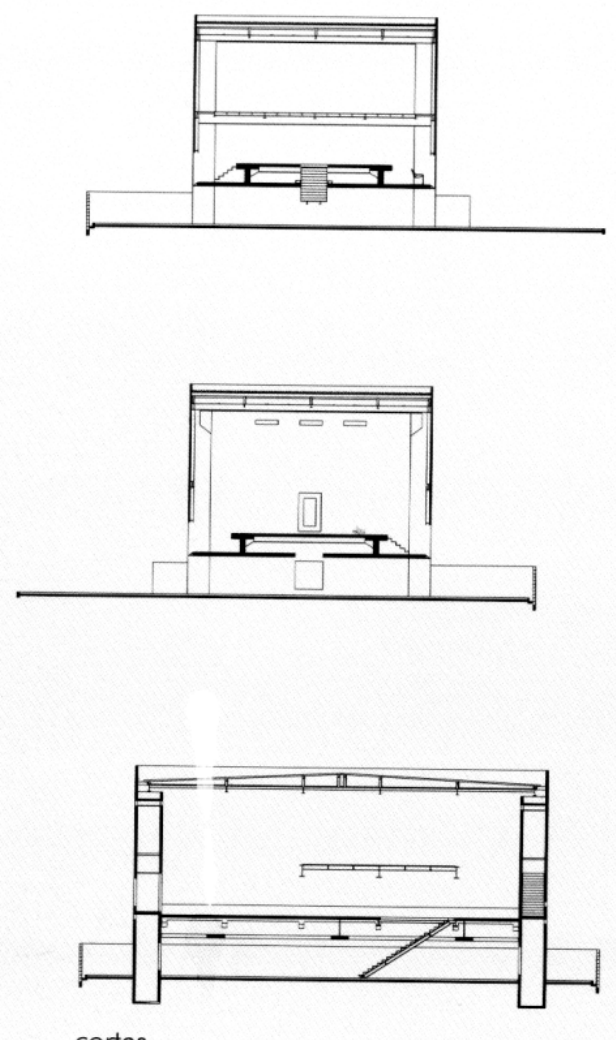

cortes

Figura 93 - Loja Forma, 1987, projeto. Fonte: Piñón (2002, p. 72, 74). 
Para Mendes da Rocha, essa "poética da técnica" faz com que uma composição tênue de aço ampare um pano de vidro por ele desenhado como uma fita de luz. Um cristal evanescente que descortina a mobília dos designers famosos em exposição, sugerindo a sua flutuação sobre o vazio intermediado pela superfície do solo. Nesse nível, se localiza o estacionamento de automóveis - necessidade do projeto que não é ignorada pela racionalidade do partido, porém, pode ser compreendida como uma vontade de liberação das amarras que atém a arquitetura ao chão.

Com esse propósito, Mendes da Rocha justifica a argúcia da técnica, a qual permite que essa vitrine longelínea elevada possa ser visualizada em alta velocidade de dentro dos carros que passam pela avenida. Da mesma forma, o arquiteto ratifica a engenhosidade que urge a esbeltez de sua fachada, podendo ser percebida como uma folha de papel com o logotipo da loja nela pintado. Nesse sentido, o discurso de Mendes da Rocha compara a mecânica da arquitetura à noção cinemática, pela qual a Loja Forma ganha movimento, no mesmo ritmo da cidade. Porém, essa percepção não implica que a Loja Forma se configure como um galpão decorado, tal como os exemplos descritos por Robert Venturi. Ao inverso, na visão de Mendes da Rocha, essa é uma proposição que se entende por não precisar utilizar nenhum disfarce. “[...] Esse edifício é uma arquitetura de simulação e de dissimulação. Não é um engodo, ao contrário, lê-se tudo, não está nada mascarado, há muita clareza estrutural". ${ }^{81}$

Todavia, levantamos a suspeita de que, no mercado publicitário, talvez não seja crível a distinção entre os meios técnicos e um fazer que não faça parte de um mundo de signos, no qual, como sugere Baudrillard (1991), a "precessão do simulacro" tomou o lugar do real. ${ }^{82}$ Nesse raciocínio, por estar imersa em uma cidade cujos significados perderam, em grande medida, os seus referentes, a Loja Forma pode então ser compreendida como um castelo da

\footnotetext{
${ }^{81}$ ROCHA, M. P. da. Visibilidade e clareza da Forma. Projeto, São Paulo, n. 175, p. 54-57, jun. 1994, p. 54.

${ }^{82}$ BAUDRILLARD, J. Simulacros e Simulação. Lisboa, Relógio d'água, 1991, p. 08.
} 
imagem. O seu acesso, feito por uma escadaria retrátil, atesta essa idéia, na medida em que encerra o espaço para que, agora, o volume sirva, na definição de Mendes da Rocha, como um grande "outdoor". 83

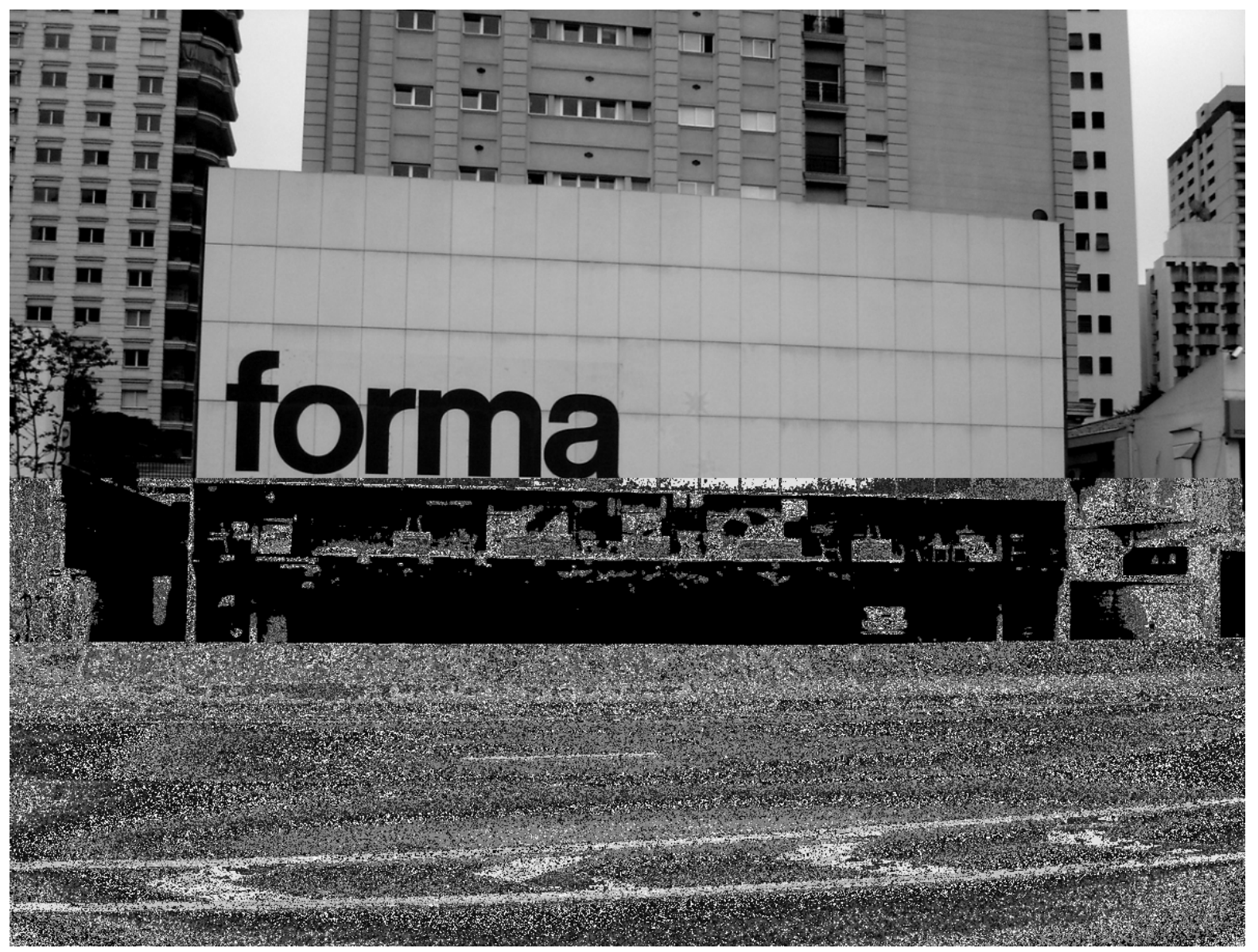

Figura 94 - Loja Forma, 1987, exterior durante o dia. Fonte: autor (jan. 2007).

\footnotetext{
${ }^{83}$ ROCHA, P. M. da. Cultura e Natureza. Loja Forma. In: PIÑÓN, H. Paulo Mendes da Rocha. São Paulo,
} Romano Guerra, 2002, p. 20. 


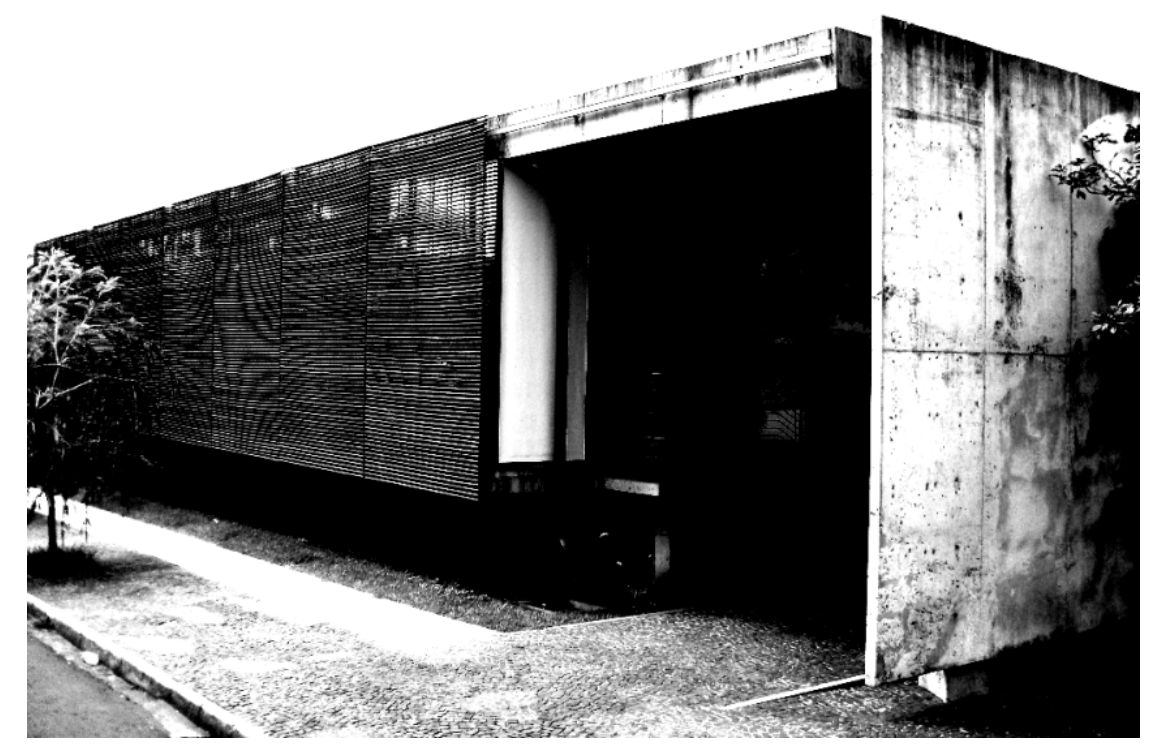

3. O PROJETO COMO IMAGEM DE SI MESMO 


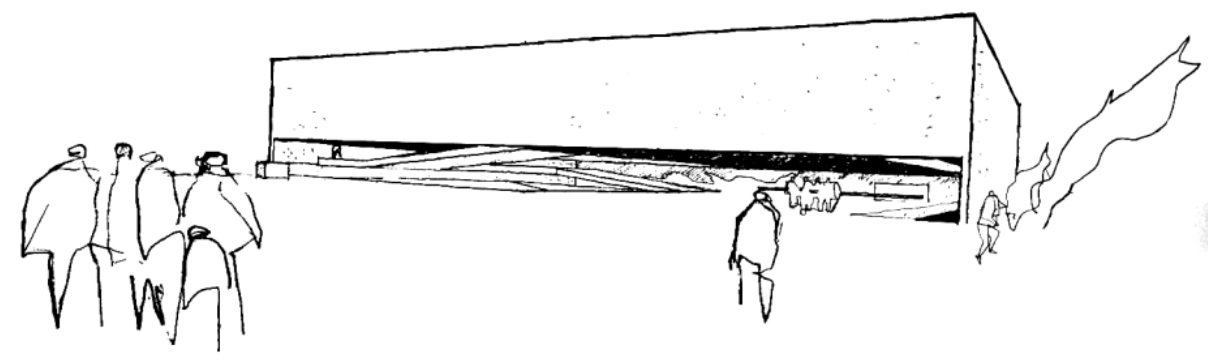

3.1. O descompasso das premissas políticas 
Os anos 80, demarcados pelo processo de abertura política no país, configuram um momento em que ressurgem os concursos nacionais de arquitetura como oportunidades para criar e romper com as amarras de uma produção lastreada pelo mercado. Porém, a mais importante tentativa aconteceu nos anos 90, com o Concurso Nacional de Anteprojetos de Arquitetura para a escolha do Pavilhão do Brasil para a Expo’ 92, em Sevilha (1990-91), organizado pelo Ministério das Relações Exteriores.

Esse concurso recebeu 165 propostas de todos os cantos do Brasil, mas a maioria foi enviada por grupos de arquitetos paulistas, inclusive a que acabou vencedora. Esta equipe era formada por Ângelo Bucci, Álvaro Puntoni e José Oswaldo Vilela - jovens profissionais saídos dos bancos da FAU/USP, os quais contaram com a colaboração dos professores Edgar Dente e Geraldo Vespasiano Puntoni e dos estudantes Clóvis Cunha e Fernanda Bárbara, além do historiador Pedro Puntoni.

Um dos membros do júri foi Paulo Mendes da Rocha, a quem muitos atribuem a escolha do trabalho premiado, por conta da aproximação do resultado formal com a chamada "arquitetura paulista". ${ }^{84}$ Embora o arquiteto tenha afirmado publicamente sua preferência por outra proposta, as idéias com as quais todos estiveram intimamente ligados na FAU/USP são muito evidentes no pavilhão vitorioso. Isso o tornou parte de um confronto entre a arquitetura moderna brasileira e uma efervescência "pós-moderna" desses anos, lida na própria ata de julgamento. ${ }^{85}$

\footnotetext{
${ }^{84}$ Logo depois da premiação do concurso, o arquiteto Márcio Mazza (1991) relata que existe "[...] um diz-quediz [...]", "[...] que o resultado do concurso para a elaboração do projeto brasileiro para a feira de Sevilha 92 deve-se diretamente à presença do arquiteto Paulo Mendes da Rocha no júri”.

85 "[...] o trabalho vencedor afirma-se pela simplicidade de recursos formais e concisão na resolução de programas complexos com que se tem caracterizado a arquitetura brasileira. Reflete a preocupação com a formação da nossa consciência sobre as relações do homem com a natureza e na ocupação do espaço, afastandose decididamente do imediatismo simbólico, do uso de tecnologias inadequadas e das soluções rebuscadas". Cf. ENTENDA o vaivém do julgamento. Ata de Encerramento dos Trabalhos do Júri. Projeto, São Paulo, n. 138, p. 39, fev. 1991, p. 39.
} 


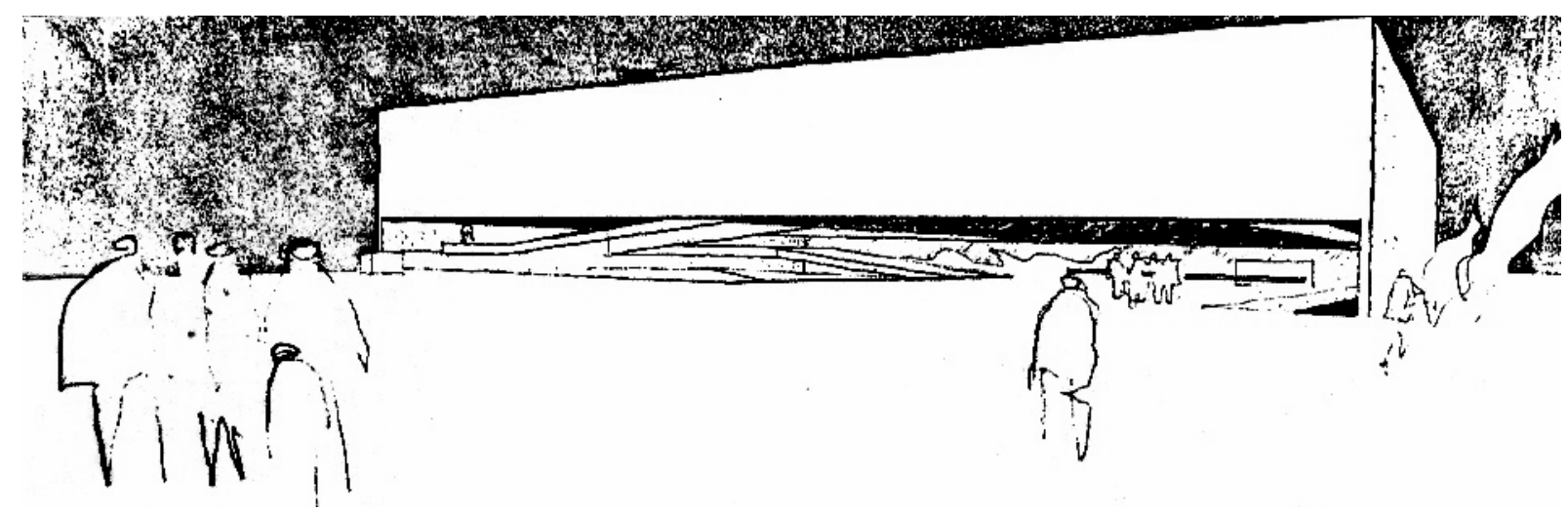

Figura 95 - Pavilhão do Brasil para a Expo’ 92, em Sevilha, 1990-91, croquis , exterior. Fonte: Bucci; Puntoni; Vilela; (1991, p. 42).

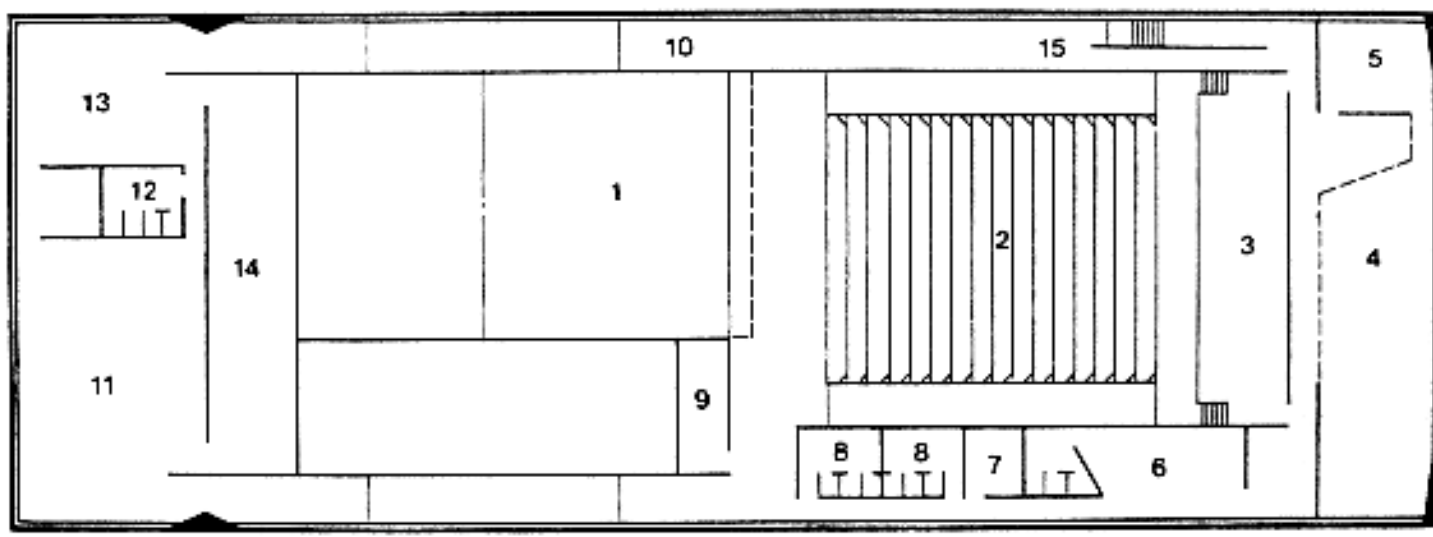

. Whel $-3.50 /+4.60$

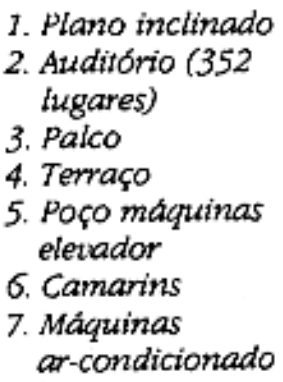

1. Plano inclinado

2. Auditorio (352

gares

5. Poço máquinas

elevador

ar-condicionado
8. Sanitários

9. Projeçào

10. Corredor senviço

11. Depóssito

12. Vestianios

13. Oficina

montagens

14. Resfriadores

ar-condicionado

15. Escada de senviço

Figura 96 - Pavilhão do Brasil para a Expo' 92, em Sevilha, 1990-91, projeto (1). Fonte: AU, n. 35 (1991, p. 66). 

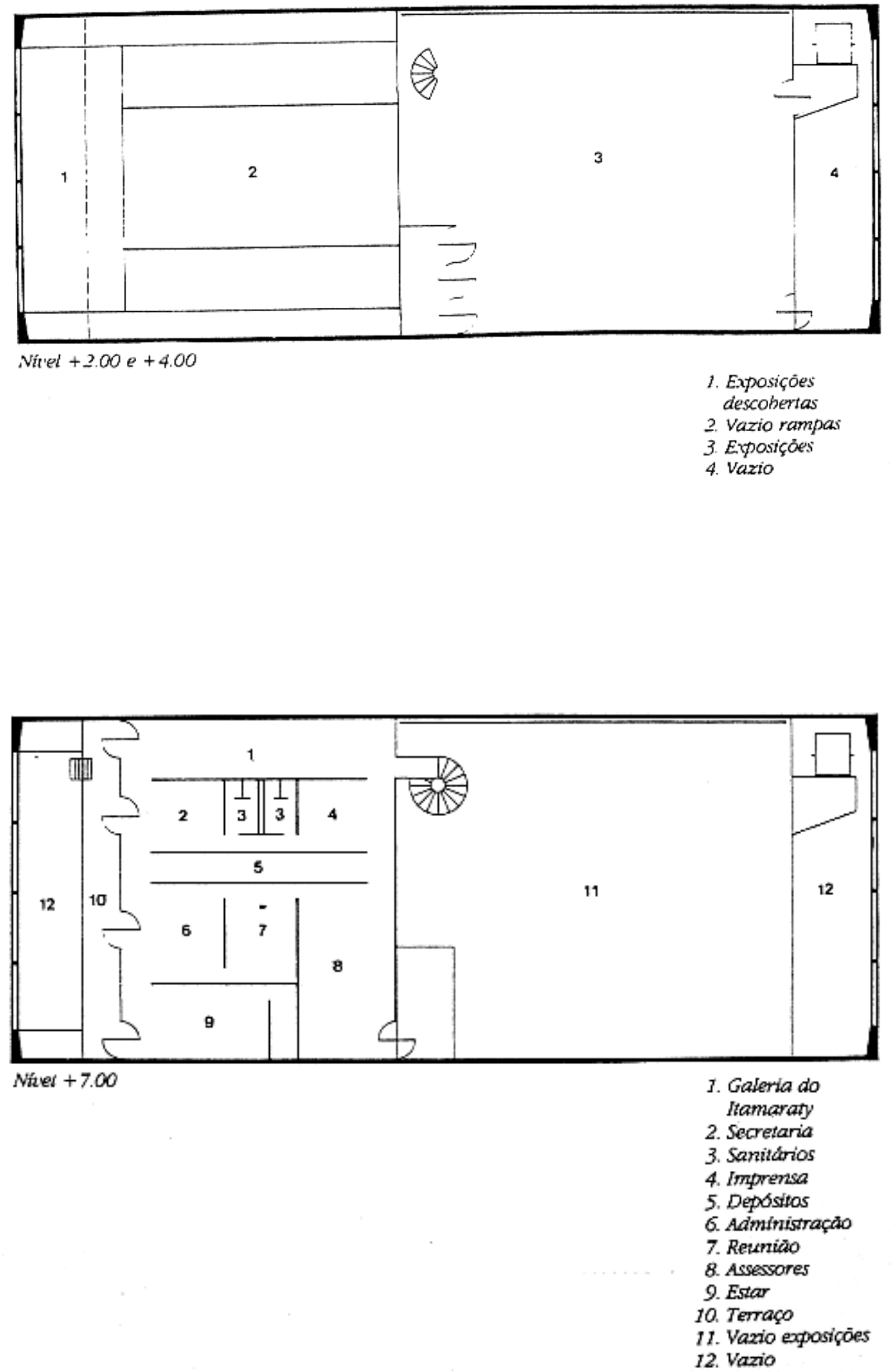

Figura 97 - Pavilhão do Brasil para a Expo’ 92, em Sevilha, 1990-91, projeto (2). Fonte: AU, n. 35 (1991, p. 66, 

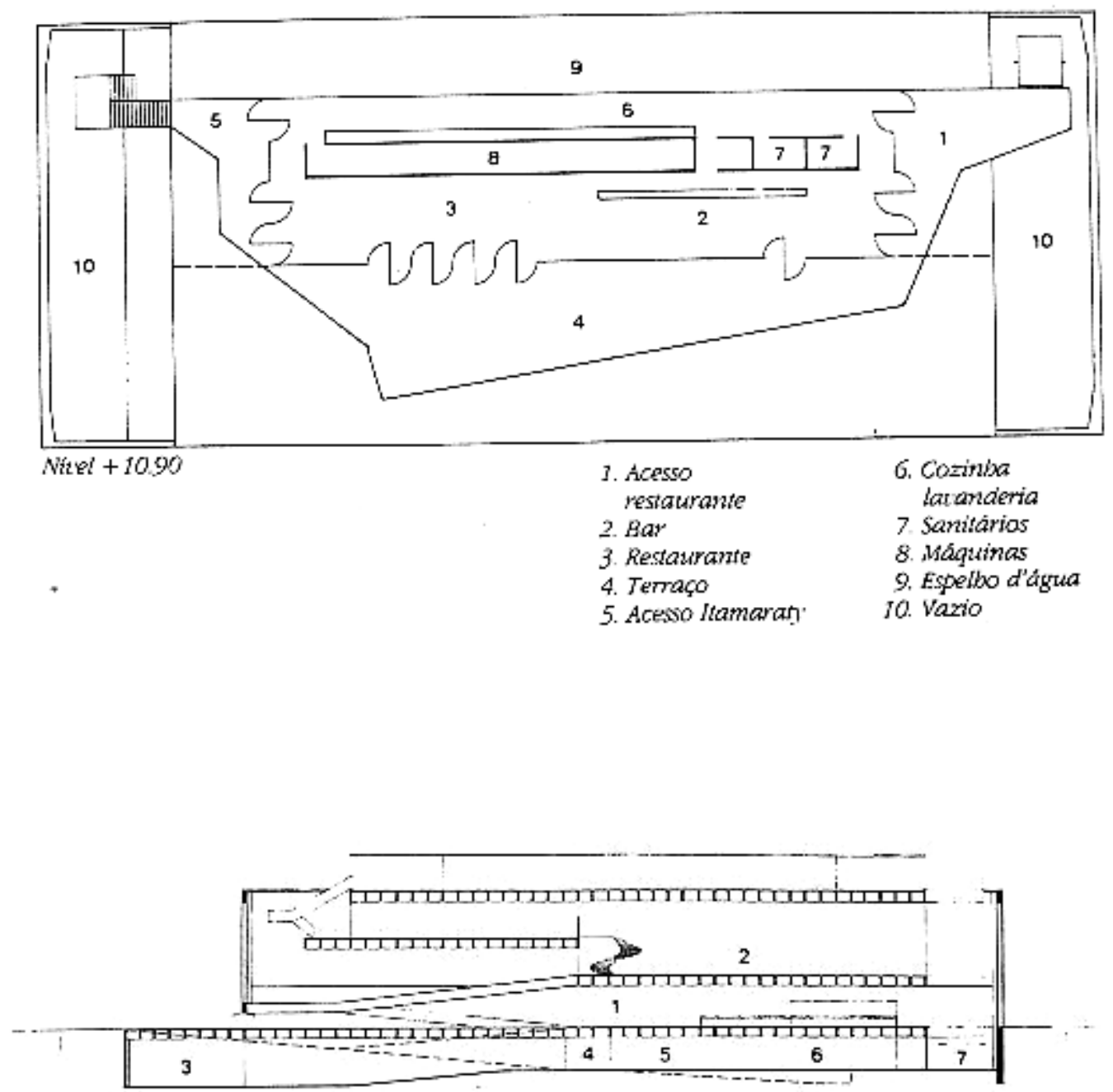

Corte $B B$

\section{Piso Sevilba \\ 2. Exposiçסes \\ 3. Depóstio \\ 4. Sanitarios \\ 5. Máquinas \\ 6. Camarins \\ 7. Terraço}

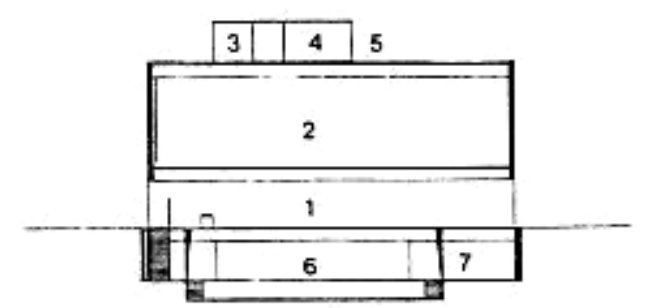

Corte $D D$
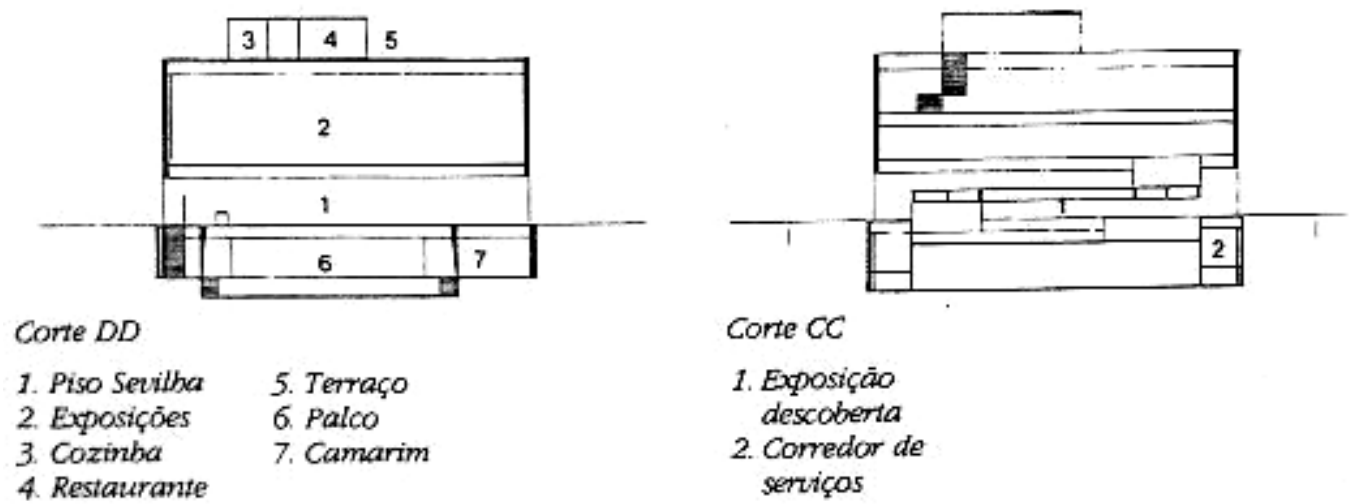

Corte $\mathrm{CC}$

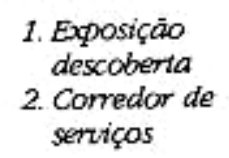

Figura 98 - Pavilhão do Brasil para a Expo’ 92, em Sevilha, 1990-91, projeto (3). Fonte: AU, n. 35 (1991, p. 67, 
É certo que o edital do concurso para o pavilhão almejava a construção de um edifício que funcionasse como um monumento à "excelência da arquitetura nacional" e, sendo assim, um tom propagandístico não pode ser desconsiderado dessa empreitada. Acatado ou não, a equipe de arquitetos paulistas apresentou uma resposta a esse desejo representativo que vinha envolto por um vocabulário de formas características dos anos 60. Porém, o que, para muitos, soava como um despautério - justamente por conta da derrocada do projeto de progresso econômico e social que alimentava esse ideário -, para os membros do grupo, essa filiação era entendida como re-visitação de um repertório ligado à "cultura brasileira". Tal possibilidade de argumentação, ao invés de se deslumbrar com uma enxurrada de imagens estrangeiras indiscriminadamente, apropriadas por vários profissionais nesse momento -, olha para a própria história à procura de uma "contribuição original”:

[...] Nosso pavilhão deve ter como orientação necessária a cultura brasileira. As formas plásticas, as soluções técnicas, as alternativas construtivas devem expressar aquilo que há de original na arquitetura nacional. A opção deve ser por uma arquitetura que se desenvolveu baseada em uma visão brasileira, em um projeto para o país. A procura das formas claras, dos traços firmes e resolutos, da construção dos espaços de amplo uso coletivo é sua característica [...]. 86

Assim, está presente no discurso da equipe paulista, o sentido de "originalidade" que Vilanova Artigas (1985) creditava aos arquitetos brasileiros como “[...] uma fórmula de abrir portas nos mercados internacionais". Mas, agora, a experimentação criativa é tomada como chave para firmação dos predicados da arquitetura nacional frente aos modismos assimilados levianamente, mantendo a crença em uma exortação dos ranços da nação, sem, no entanto, consolidar o distanciamento suficiente para compreender que tal proposição não poderia ser

\footnotetext{
${ }^{86}$ BUCCI, A; PUNTONI, A.; VILELA, J. O. Pavilhão do Brasil na Expo 92 Sevilha. Projeto, São Paulo, n. 138, p. 40, fev. 1991, p. 40.
} 
conseguida sem que houvesse um posicionamento político diante dos entraves impostos pelo chamado "capitalismo tardio".

Se levarmos em consideração as observações de Schwarz (1986) sobre o "caráter imitativo da nossa vida cultural”, essa preocupação da equipe buscará se esquivar dessa atitude que, frequentemente, tende a se apropriar da produção mais recente dos países avançados, abandonando totalmente as reflexões postuladas pelas gerações anteriores. Entretanto, apenas aparentemente, essa noção pode ser aqui utilizada, pois apesar da idéia de retomada crítica do trabalho dos precursores transparecer no discurso projetual desse grupo de arquitetos, ela não se ratifica, porque, ao fugir de uma compilação do que está em voga, o projeto vencedor talvez mimetize a produção da chamada "arquitetura paulista", menos como uma prática acurada e mais como retórica. Assim, ao invés de trazer à tona suas "contradições contemporâneas", "solicitando o passo adiante" ${ }^{87}$, o trabalho dessa jovem equipe de arquitetos persiste no desejo de abandono de um "anátema", sem constituir uma intervenção na cultura capaz de confrontar os dramas atuais da realidade do país.

Nesse caso, o projeto do Pavilhão do Brasil para a Expo' 92 pode revelar o esforço em favor da constituição de uma proposta técnico-criativa que, antes, tinha como prerrogativa uma política antiimperialista, mas agora, se configura como ação arrolada por uma reutilização da linguagem paulista, em face dos recentes processos de culturalização. Com o agravante de que, no passado, havia um enfrentamento, apesar deste não ter redundado em nenhuma alteração da estrutura de classes. Porém, hoje, há uma despolitização que se desvela pelo abrandamento da capacidade de embate e pela manutenção das coisas como estão.

Nessa leitura, dezenas de propostas enviadas ao concurso gravitaram em torno de uma apropriação estética e tecnológica que ño condizia com nossa realidade díspar, enquanto o

\footnotetext{
${ }^{87}$ SCHWARZ, R. Nacional por Subtração. In: SCHWARZ, R. Cultura e Política. São Paulo, Paz e Terra, 2001, p. 111. (artigo originalmente publicado em: Folha de São Paulo, 07 jun. 1986).
} 
desenho ganhador recorria à duvidosa utilização do concreto armado. Isto porque, pensar um projeto inteiro para Sevilha com essa técnica, diante do curto prazo para sua execução, dos problemas de fornecimento de material e da dificuldade de mão-de-obra no canteiro andaluz, era também uma contradição. Vale ressaltar que a Espanha, neste momento, vive uma corrida para terminar as obras da Expo' 92 concomitantemente às Olimpíadas de Barcelona, como justificou Segawa (1991).

Essa atitude revelaria um descompasso técnico-construtivo em Sevilha, pois a cidade apresenta uma grande variação de temperatura, como atentou Segawa (1991). Sendo assim, a esplanada do pavilhão, para ser "um convite ao descobrimento, ao uso coletivo" precisaria ter, no mínimo, algo que a resguardasse nos dias de inverno, o que obrigaria os autores do projeto a repensarem todo o seu partido. Do contrário, resultaria numa imensa praça sombreada, mas desértica.

Mesmo assim, a equipe paulista opta pelas estruturas de concreto armado, entrevendo nelas a idéia de uma solução técnica adequada. No entanto, essa opção, de longa data, já se mostrava imprópria ao nosso clima. Entretanto, se, há algumas décadas, essas conformações espaciais sacrificavam o conforto ambiental do edifício em benefício de uma questão ética, no pavilhão vencedor, essa acepção se desloca para o campo da estética.

Por esse fato, se recuperarmos algumas soluções espaciais do pavilhão premiado, elas apontarão para a organização de um programa que esbarra em antigos pressupostos projetivos tomados ao pé da letra, sem que o comprometimento social, técnico e econômico que estava por detrás da construção da Forma na chamada "arquitetura paulista" pudesse ser trazido à tona. Nessa análise, assinalamos alguns problemas que dizem respeito, inclusive, à carência de destreza na formalização do trabalho vencedor. Se levarmos em consideração as obras do passado, muitas são as lacunas de uma ordem projetiva pouco capciosa, pois a revalidação de 
um glossário das espacializações de outrora não resultou numa mesma generosidade de ambientes, ao inverso, revelou-a inapropriada.

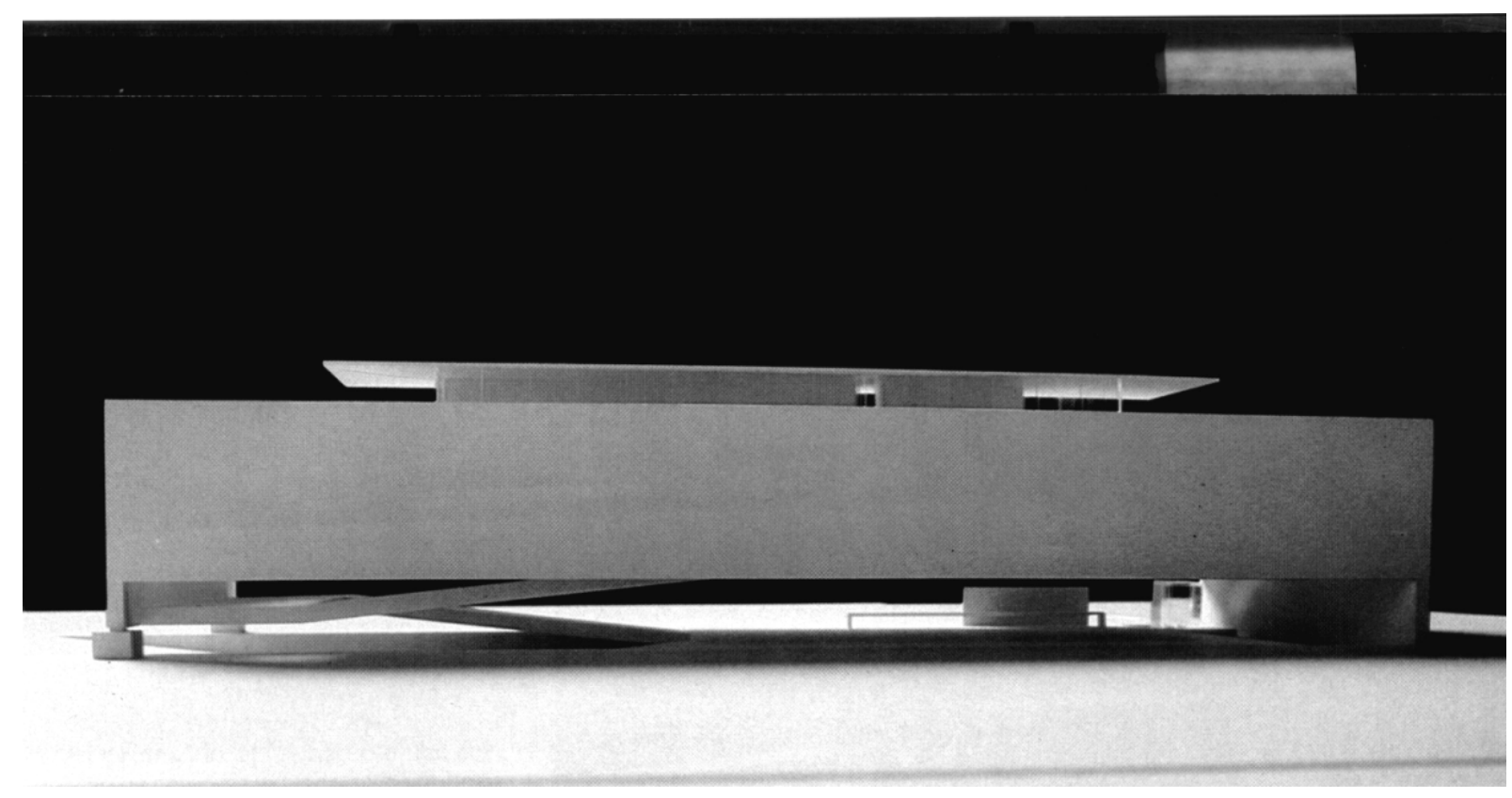

Figura 99 - Pavilhão do Brasil para a Expo' 92, em Sevilha, 1990-91, maquete. Fonte: AU, n. 35 (1991, p. 67).

De acordo com Segawa (1991), o projeto apresenta uma desproporção da grande área destinada ao térreo do edifício devido ao baixo pé direito, produzindo o que o autor chama de um "espaço amesquinhado". Ainda segundo o crítico, os amplos espaços vazios não têm uma “intencionalidade imediata". Do mesmo modo, a laje-rampa que ocupa a metade do piso do subsolo aparece mais como "um capricho" que uma maneira de resolver o estacionamento de automóveis desse nível, como havia sido solicitado pelo edital.

Assim, o projeto do pavilhão vencedor de Sevilha talvez não tenha o mesmo tirocínio das estruturas delgadas pensadas para o pavilhão de Osaka, nos anos 70. Muito embora os arquitetos da equipe paulista promovam um sentido de aproximação entre ambos os pavilhões, sobretudo, quanto ao discurso de Paulo Mendes da Rocha e equipe sobre o piso do futuro edifício se confundir com o próprio terreno, existem diferenças muito claras se comparados os dois projetos: 
[...] À transitoriedade de Osaka se contrapõe a permanência definitiva do pavilhão

na Espanha; ao espaço inundado da luz zenital do Oriente se contrapõe a introspecção cúbica ibérica. Não há, no projeto vencedor, a fineza dos jogos de luzes, os 'achados' que caracterizam o passo à frente da obra de Paulo Mendes da Rocha sobre as imediatas referências a Artigas e Niemeyer. [...] A proporção dos espaços, o controle dos níveis e a circulação no projeto vencedor ostentam características controversas para mim. [...]. ${ }^{88}$

Diante dessas considerações, é lícito atentar para o fato de que, em Osaka, se fazia presente o concreto armado como um material possível e, embora existissem deficiências, ainda se podia expressar o domínio técnico e a criatividade dos profissionais brasileiros em qualquer parte do mundo. Nesse sentido, apesar dos anacronismos de toda a ordem, naquele momento, a técnica servia, no discurso dos arquitetos paulistas, para proclamar nossos saltos, almejando um "significado humanístico". Porém, agora, a propriedade dessa autoridade, aos poucos, vai sendo subtraída, porque o concreto armado, ao contrário do que afirma a equipe vencedora, já não é sinônimo de ousadia apenas por projetar os típicos grandes "vãos de 60 e $70 \mathrm{~m} " .89$

Nessa leitura, com a redemocratização do país e a abertura dos mercados, as carências materiais e tecnológicas do Brasil se agravam. Ao se descortinar um ideário de globalização, ficam mais nítidas as defasagens em relação aos outros países, demonstrando nossa grande distancia social, técnica e econômica. Uma condição que não supõe, ainda, podermos nos valer da destreza técnica para superar algumas das nossas contradições e, assim, conseguir uma equiparação internacional, mesmo porque, diante do quadro mundial que se esboça, há

\footnotetext{
${ }^{88}$ SEGAWA, H. Pavilhão do Brasil em Sevilha: deu em vão. Projeto, São Paulo, n. 138, p. 34-39, fev. 1991, p. 35.

${ }^{89}$ BUCCI, A; PUNTONI, A.; VILELA, J. O; DENTE, E.; PUNTONI, P. A polêmica de Sevilha e os premiados no Concurso do Pavilhão do Brasil. [Entrevista para Suzana Barelli]. In: A Polêmica de Sevilha e os premiados no concurso do pavilhão do Brasil. Projeto, São Paulo, n. 139, p. 62-63, mar. 1991, p. 63. Nesta entrevista, os arquitetos da equipe vencedora, ao inverso do que supomos, atestam esse "know-how" construtivo como uma forma de afirmação "tecnológica", sobretudo, por expressar as características da "cultura brasileira".
} 
uma "[...] impossibilidade crescente, para os países atrasados, de se incorporarem enquanto nações e de modo socialmente coeso ao progresso do capitalismo [...]”, como argumenta Schwarz (1994). ${ }^{90}$

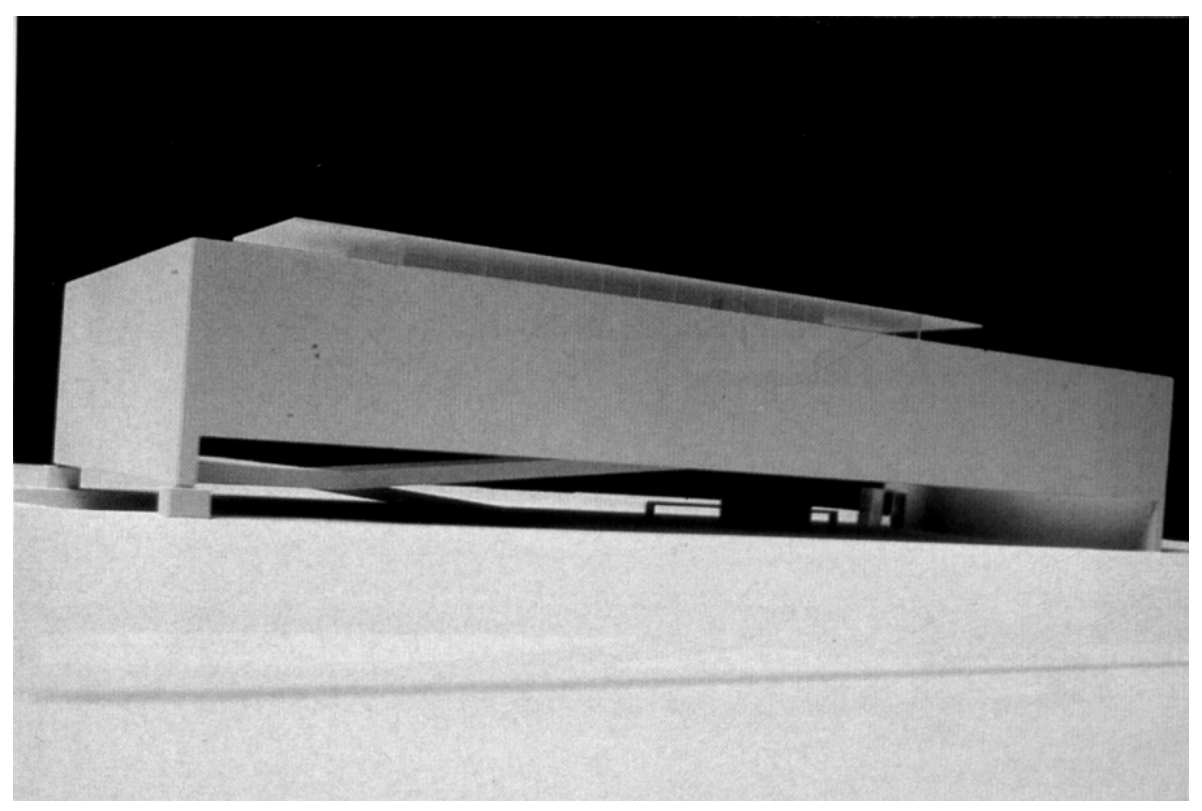

Figura 100 - Pavilhão do Brasil para a Expo’ 92, em Sevilha, 1990-91, maquete. Fonte: AU, n. 35 (1991, p. 68).

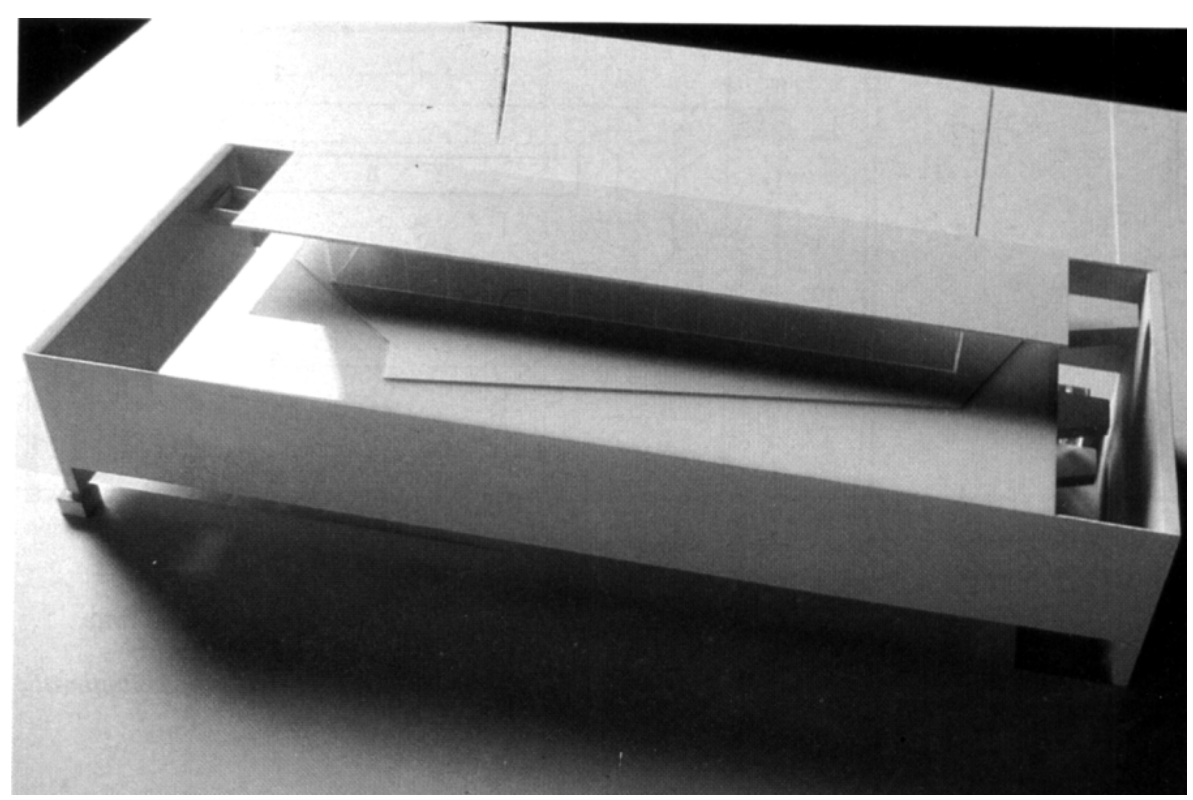

Figura 101 - Pavilhão do Brasil para a Expo’ 92, em Sevilha, 1990-91, maquete. Fonte: AU, n. 35 (1991, p. 68).

\footnotetext{
90 SCHWARZ, R. Fim de século - incompleto, o processo de modernização se provou ilusório. Folha de São Paulo, São Paulo, 04 dez. 1994, p. 03.
} 
Sob esse ângulo, a técnica como expressão da cultura nacional no projeto premiado do pavilhão apenas alude a uma arquitetura que fora consubstanciada nos anos 60 como modo de encobrir as dificuldades políticas da arquitetura brasileira dos anos 90. Um momento em que grande parte da arquitetura produzida na cidade de São Paulo será marcada pelas imposições do capital financeiro, sendo, obviamente, indiferente à miséria que a rodeia. ${ }^{91}$ Situação que se esboça a contragosto do que os profissionais esperavam da profissão e da própria "arquitetura paulista", ante um desenvolvimento truncado de suas premissas em favor de uma aparência estética.

Sendo assim, se muito do que foi erguido da arquitetura do passado paulista só deixou dúvidas quanto à viabilidade de uma promessa coletiva, na década de 60 , ainda se podia crer em uma reviravolta cultural, pela confiança de que os procedimentos técnicos nos garantiriam certa emancipação. Porém, agora, essa mesma compreensão é o que, talvez, impeça uma evolução. Um sentido que nos enfraquece, abrindo o caminho para uma importação de modelos externos e de segunda mão. ${ }^{92}$

Desta maneira, as grandes vigas protendidas do pavilhão da equipe vencedora revelam as "piruetas estruturais" com as quais um tom escolástico da produção paulista - entendido aqui pela apropriação de um vocabulário formal, em prejuízo dos princípios revolucionários ganhou fama e passou a ser consumido como saída construtiva. Trata-se de uma proposta que, de acordo com Mazza (1991), vem carregada apenas de "valores simbólicos" - assim como o "imediatismo" ora descrito na ata de julgamento -, mas que não consegue legitimar a ambição que materializa, exatamente porque tudo está "decalcado" de outros projetos.

${ }^{91}$ Cf. HORIN, E. São Paulo - as marginais do Rio Pinheiros e os megaprojetos arquitetônicos do capital financeiro: tempos de globalização. São Carlos, São Paulo, dissertação de mestrado apresentada à EESC-USP, 2003.

92 GAUDENZI, L. M. Alguém foi desrespeitado? [opinião do leitor: Repercussões do Concurso de Sevilha]. Projeto, São Paulo, n. 140, p. 10-15, abr. 1991, p. 12. “[...] Não será se olhando no espelho, menos ainda no álbum de recordações que a arquitetura brasileira se desenvolverá, nem através dos concursos cujos resultados demonstram uma atitude conservadora, medo de descobrir novas soluções que contém as raízes e a história de nossa arquitetura, mas que descobre novas emoções, numa expressão mais autentica e atual do próprio legado". 
[...] faltam o rigor das proporções, a transparência, a elegância, a leveza. Dizem os arquitetos, no memorial, que 'o pavilhão parece flutuar sobre o solo apoiado em apenas quatro pontos'. Imagem também já muito desgas tada, que não transparece na maquete, nem nos cortes ou nas perspectivas; o edifício é bojudo. Não é a ausência de apoios que faz necessariamente um projeto parecer 'flutuar'; igualmente não é o grande vão que necessariamente transmite leveza. Vide a garagem de barcos do Artigas na Guarapiranga: tão leve, que parece pronta para decolar. Nem necessariamente um projeto tem que parecer leve para ser bom. Vide MASP. ${ }^{93}$

Ainda que a valorização de um conhecimento seja o tom do discurso dos membros da equipe paulista, a estrutura do pavilhão, por ser desprovida dos antigos pressupostos políticos, se mantém amarrada apenas ao léxico da arquitetura de Artigas. Assim, a proposta brasileira para a Expo' 92 em Sevilha, em comparação com a FAU/USP, resulta em um projeto que tem proporções "desajeitadas": ao invés dos pilares que articulam o pouso sobre o solo, tem dois maciços cubos que fazem com que o edifício pese sobre o piso no qual, metaforicamente, se imaginava poder "flutuar". Diferentemente da linha aberta por Artigas, esse edifício não pode alçar o vôo estrutural pelas artimanhas da técnica.

Por esse fato, como atesta Ricardo Marques Azevedo (1991), se há uma recorrência nessa arquitetura do projeto vencedor para Sevilha é a sua característica “[...] claustrólatra de encerrar, enterrar, imergir, voltar-se para dentro e evitar qualquer contágio com o exterior". Nessa medida, não há como fazer referência nem a um amplo espaço aberto, nem mesmo ao uso coletivo, já que o pavilhão é uma caixa hermeticamente cerrada que, inclusive, dificulta a circulação interna. Se essa condição de encarceramento do edifício surtia, no passado, um

\footnotetext{
93 MAZZA, M. Vertiginosa ascensão ao anonimato ou lânguida preguiça. [opinião do leitor: Repercussões do Concurso de Sevilha]. Projeto, São Paulo, n. 140, p. 10-15, abr. 1991, p. 14.
} 
desejo de rechaço a uma ordem imposta, não parece nem um pouco conveniente, a uma exposição universal, um prédio ser "refratário ao diálogo com o contexto". 94

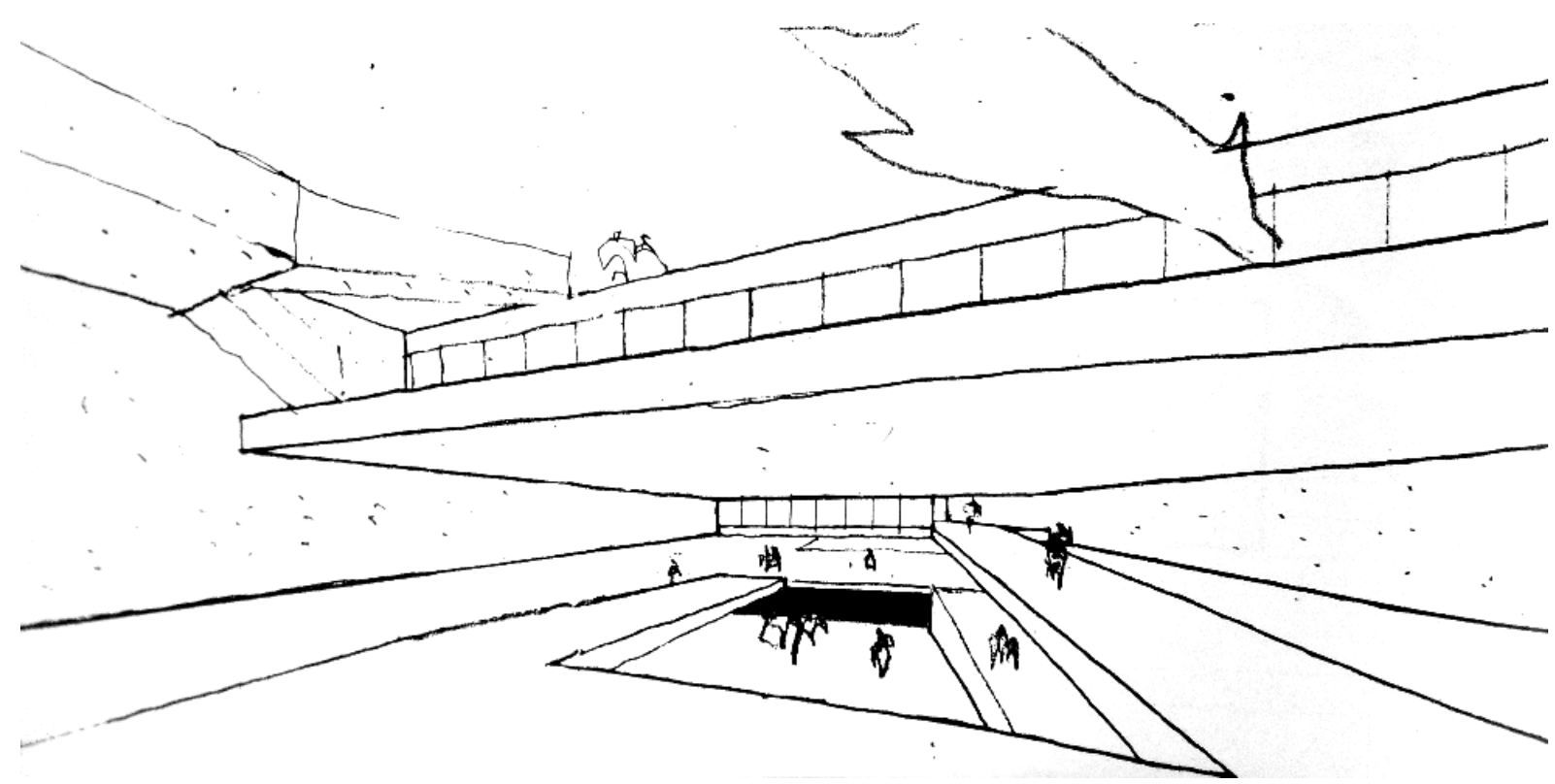

Figura 102 - Pavilhão do Brasil para a Expo' 92, em Sevilha, 1990-91, croquis, interior. Fonte: Bucci; Puntoni; Vilela; (1991, p. 42).

Entendido sob esses aspectos, o pavilhão da equipe paulista é um projeto para o qual o entorno faz pouca diferença, ao contrário de Osaka. Os seus croquis reforçam o caráter de um edifício solto no espaço que pode se aderir a qualquer realidade. Talvez, essa tendência tenha concorrido para que esse pavilhão fosse o escolhido. Sem ter ao que se contrapor e longe de configurar uma promessa, a grande cobertura é meramente reposta diante dos novos termos da marcha capitalista, num momento em que a arquitetura produzida no país altera drasticamente as suas postulações, sobretudo, por estar cada vez mais vinculada ao mercado e à mídia. ${ }^{95}$

\footnotetext{
${ }^{94}$ AZEVEDO, R. M. de. Futuro Passado. $A U$, São Paulo, n. 35, p. 76-79, abr./maio 1991, p. 78.

95 ETCHEBEHERE, J. O grito afônico das velhas e ultrapassadas lições. [opinião do leitor: Repercussões do Concurso de Sevilha]. Projeto, São Paulo, n. 140, p. 10-15, abr. 1991, p. 15.
} 
Talvez por isso, a polêmica criada em torno do pavilhão vencedor enverede para uma batalha puramente estética, dividindo as opiniões dos arquitetos que defendem o moderno ou o "pós-moderno". 96 No entanto, acreditamos que o debate deveria girar em torno das questões que afligiam a cidade e a sociedade brasileira nesses anos, pois, ao evitar a crítica dos descompassos presentes na realidade do país, recaímos na discussão vazia, mediada pela recuperação de um repertório de formas. Porém, se há algo a retomar da chamada "arquitetura paulista", não é exatamente o seu formato ou apenas a sua técnica construtiva, mas, antes, os procedimentos que a originaram. Melhor dizendo, reconstruir um esforço reflexivo e político para reconfigurar uma linguagem arquitetônica.

Na medida em que não verificamos tal possibilidade na obra premiada para Sevilha, o projeto poderia dizer respeito à própria política neoliberal que, inclusive, manteve o edifício apenas como imagem, já que este não chegou a ser construído. Talvez, o próprio concurso era, por si mesmo, mais um incremento midiático e mercadológico que acometeu a arquitetura. Nesse caso, o saldo dessa premiação também contribuiu para fragilizar a proposta vencedora. Sendo assim, incapaz de artic ular uma virada cultural, esse pavilhão pode ser entendido como uma concepção arquitetônica que antecipará o traço dos próximos anos.

\footnotetext{
${ }^{96}$ Cf. PUNTONI, P. A negação do Pós Moderno e a Negação do Moderno. Caramelo, São Paulo, n. 02, p. 0411, jun. 1991.
} 


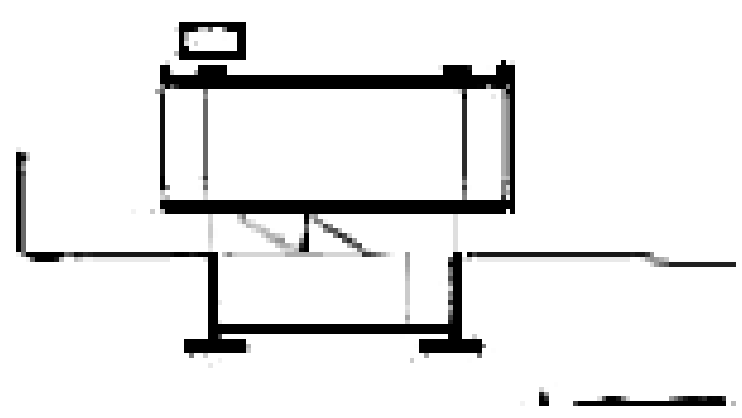

3.2. Os impasses da beleza da imagem 
Na segunda metade dos anos 80, a organização dos arquitetos paulistas em equipes era muito freqüente entre os recém-formados, especialmente, visando a participação nos concursos públicos de arquitetura. Porém, perante a frustração por não ter um projeto premiado construído e diante da dificuldade de encomendas frente à crise do governo Collor, quando a arquitetura passa a ser uma atividade dominada pelas construtoras, empreiteiras e escritórios estrangeiros, o trabalho cooperado perpetua-se como uma alternativa para a sobrevivência. Então, para enfrentar os desafios dos anos 90, esse exercício conjunto da arquitetura resultou num inusitado encontro de gerações, como o exemplo das colaborações entre Paulo Mendes da Rocha e alguns jovens arquitetos. ${ }^{97}$

Nesse caso, o contato já havia sido iniciado há uma década atrás, ainda na FAU/USP, quando Mendes da Rocha voltou a lecionar, depois da anistia. Assim, como consequiência da vivência na escola, nutrida pelo retorno da práxis projetual, do hábito de trabalhar em grupo e da divisão de tarefas, pôde se configurar, na vida profissional, o vínculo entre ex-alunos e o professor. Uma aproximação transformada em uma escolha "ideal" de trabalho, balizada pela amizade e parceria, buscando driblar os impedimentos de uma prática pública da disciplina, na tentativa de "preservar a integridade do projeto, enfrentando a vertigem do mercado". 98

Essa preocupação é o que alimenta o pensamento dos membros das equipes de jovens arquitetos que, tendo acumulado um domínio da prática e pelo reconhecimento obtido nos concursos de arquitetura, buscam reforçar, nos seus trabalhos solo, o interesse pela "cidade" e

\footnotetext{
${ }^{97}$ O início das parcerias de Mendes da Rocha com jovens arquitetos remonta a dois projetos de sua autoria: a Capela de São Pedro (1988), em Campos do Jordão-SP, juntamente com o arquiteto Eduardo Colonelli; e o MuBE (1987-95), em São Paulo, com José Armênio de Brito Cruz, do Piratininga Arquitetos Associados. Logo depois, no projeto da Pinacoteca do Estado (1993), em São Paulo, novamente com Eduardo Colonelli, além de Weliton Ricoy Torres. Mais tarde, no Terminal de Ônibus do Parque D. Pedro II (1995-96), no Centro Cultural Fiesp (1996-98), no Poupatempo Itaquera (1998-2000) e na Oca do Ibirapuera (1999), em São Paulo, com o MMBB Arquitetos. Cf. SERAPIÃO, F. Especial Paulo Mendes da Rocha. Consagração, no escritório virtual: do MuBE ao Pritzker. Projeto, São Paulo, n. 316, p. 52-55, jun. 2006, p. 52.

${ }^{98}$ ROCHA, P. M. Tentamos sempre preservar a integridade do projeto, enfrentando a vertigem do mercado. [entrevista a Fernando Serapião e Silvério Rocha junto de integrantes das equipes: Ricoy Torres e Colonelli, Piratininga Arquitetos, MMBB Arquitetos e Metro Arquitetos]. Projeto, São Paulo, n. 275, p. 06-11, jan. 2003, p. 06.
} 
pelo "território", num desejo de compreender a "organização urbana" e as "redes de infraestrutura". ${ }^{99}$ Um discurso que se reflete na maneira como um dos grupos próximos de Paulo Mendes da Rocha, o MMBB Arquitetos ${ }^{100}$, procura encaminhar os seus projetos em algumas obras na capital paulista ou no interior do Estado. ${ }^{101}$

Um desses trabalhos é a Clínica de Odontologia (1998-2000), na cidade de Orlândia. Esse projeto foi escolhido entre críticos de arquitetura do Brasil como uma das melhores obras erguidas durante a década de $90 .{ }^{102}$ As semelhanças formais dessa clínica, hoje consagrada, com o trabalho premiado no concurso para o Pavilhão do Brasil para a Expo'92 em Sevilha, que outrora havia sido criticado pela recuperação de traços da chamada "arquitetura paulista", não tardaram em ser apontadas. Na tentativa de compreender os parâmetros da crítica para o julgamento de ambos, foi levantada a questão: “[...] na década que separa Sevilha de Orlândia, mudaram os arquitetos ou mudou a crítica?”. ${ }^{103}$

\footnotetext{
${ }^{99}$ BRAGA, M. Nos anos 80 o interesse renovado pelo projeto e o domínio da prática. Projeto, São Paulo, n. 228 , p. 97 , jan./fev. 1999, p. 97.

${ }^{100}$ O MMBB Arquitetos foi formado por integrantes do escritório Via Arquitetura (1988), dentre eles Fernando de Mello Franco, Marta Inês da Silva Moreira e Milton Liebentritt de Almeida Braga; além de Ângelo Bucci, do escritório Arquitetura Paulista (1989), que integrou a equipe de 1996 a 2003 e, desde então, compõe o SPBR Arquitetos. Vale ressaltar também que todos os integrantes do grupo paulista MMBB Arquitetos são graduados pela FAU/USP na segunda metade dos anos 80 e tivera m projetos premiados no concurso para o Pavilhão da Expo' 92, em Sevilha. Cf. SANTOS, C. R. dos. Novíssimos Arquitetos. Projeto, São Paulo, n. 143, p. 54-73, jul. 1991, p. 68; 73.

101 Em São Paulo, o MMBB Arquitetos conquistou o Prêmio EX-AEQUO, na IV Bienal Internacional de Arquitetura de São Paulo - BIA com o projeto para a Garagem Trianon (1996-1999), que teve como colaborador: a arquiteta Keila Costa; o paisagismo de Marcelo Suzuki; a estrutura concebida pela Proenge Engenharia de Projetos S/C; e a construção por conta da Construbase - Construtora de Obras Básicas de Engenharia. Cf. GARAGEM Trianon. $A U$, São Paulo, n. 88, p. 78-79, fev./mar. 2000. Leia também: GARAGEM Trianon. Projeto, São Paulo, n. 239, p. 51. jan. 2001. No interior, no município de Orlândia, por decorrência de uma "implantação singular" na cidade, o projeto para a Clínica de Psicanálise (1995-98) foi indicado ao $2^{\circ}$. Prêmio Mies van der Rohe de Arquitetura para a América Latina (2000). Cf. MUNGIOLI, A. (Ed.). Cotas de ocupação, percurso de acesso e controle da luz marcam relação entre espaço público e privado. (Clínica de Psicanálise). Projeto, São Paulo, n. 237, p. 66-71, nov. 1999. Leia também: DEGELO, M. Divã ousado. (Clínica de Psicanálise de Orlândia, MMBB). Casa e Jardim, São Paulo, ano 51, n. 601, p. 80-4, fev. 2005.

102 A revista Projeto promoveu em 2001 um debate sobre os rumos da arquitetura atual, lançando cinco perguntas; dentre elas: Quais os cinco principais projetos de arquitetura concluídos no Brasil na década de 90 ? Dois dos entrevistados, Antônio Carlos Sant' Anna Jr. e Mateus Gorovitz opinaram, dentre outras obras, pela Clínica de Odontologia de Orlândia. Cf. SERAPIÃO, F. Debate: A opinião dos críticos. A Arquitetura Brasileira evoluiu apesar das dificuldades impostas pela globalização. Projeto, São Paulo, n. 251, p. 42-47, jan. 2001.

${ }^{103} \mathrm{O}$ debate promovido pela revista Projeto, n. 251, em 2001 e a opinião dos críticos motivou o artigo de Adilson Melendez, que compara, esteticamente, o pavilhão premiado de Sevilha e a Clínica de Odontologia de Orlândia - vale ressaltar que os dois projetos têm a co-autoria do arquiteto Ângelo Bucci -, na tentativa de
} 
Antes, o que estava em jogo era um inflamado juízo estético, quando o debate deveria ser travado no âmago de desdobramentos sistêmicos, que incluíam uma transformação da arquitetura em imagem. Salvo engano, o que vemos, agora, são as implicações dessa discussão, verificando-se que muito da crítica foi sendo substituída por exuberantes fotografias que entronizam os projetos recentes. O que aparece nos principais compêndios de arquitetura contemporânea brasileira são ilustrações que, muitas vezes, sucumbem o discurso dos arquitetos, o contexto e, sobretudo, os meios de produção. As análises, com frequiência, são restringidas a frases de efeito. A Clínica de Odontologia de Orlândia, presente em muitos desses catálogos, é elogiada por sua "sóbria inserção urbana”, sem que, contudo, se possa ter a noção do seu entorno imediato, por conta dos ângulos das fotos que, frequentemente, são apresentadas. 104

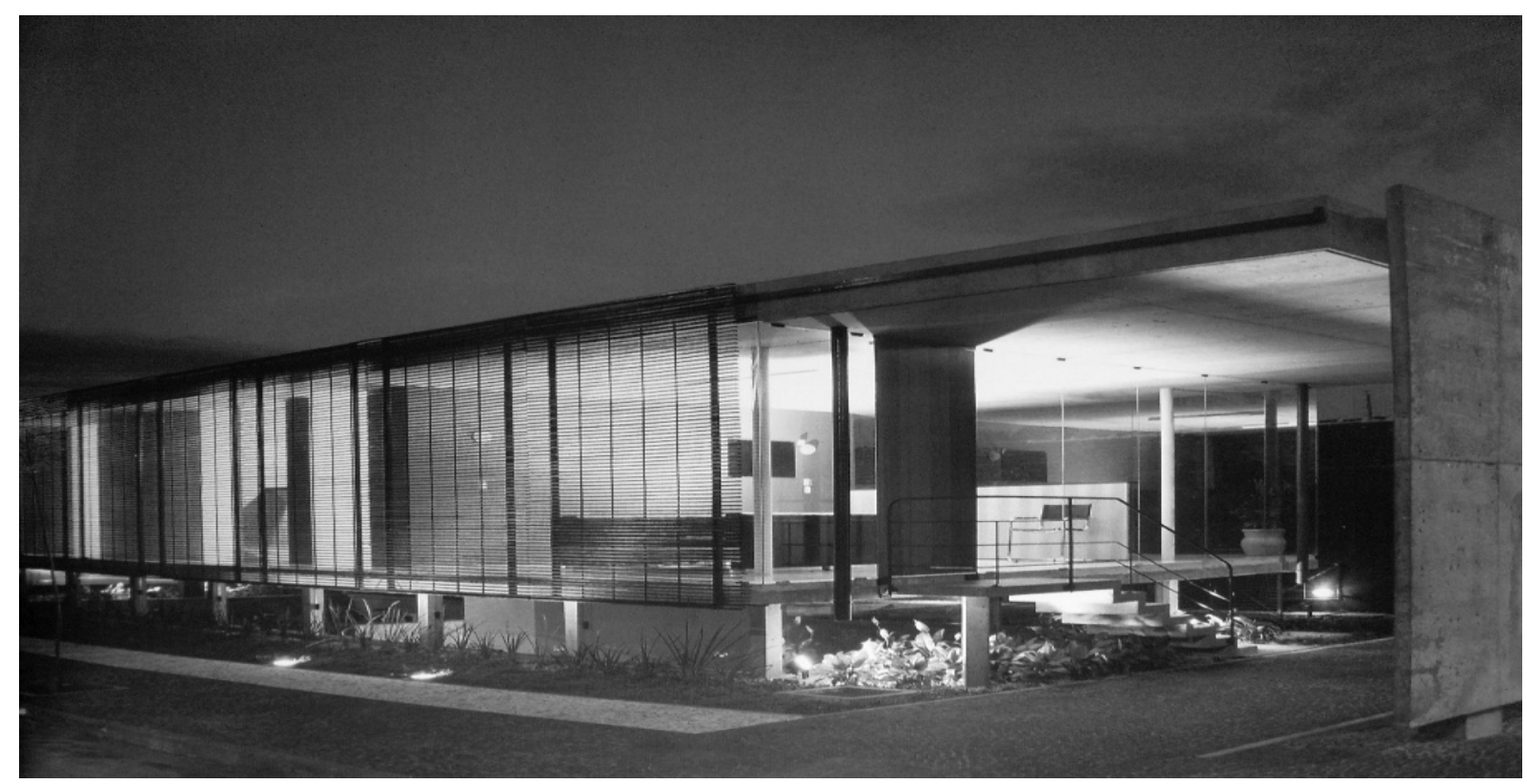

Figura 103 - Clínica de Odontologia, 1998-2000, exterior. Fonte: Segre (2003, p. 189).

compreender os parâmetros para um julgamento de ambos. Cf. MELENDEZ, A. Na década que separa Sevilha de Orlândia, mudaram os arquitetos ou mudou a crítica? Projeto, São Paulo, n. 251, p. 132, jan. 2001, p. 132.

104 Este trecho faz menção ao livro de Roberto Segre. Cf. SEGRE, R. Arquitetura Contemporânea Brasileira. Rio de Janeiro, Viana \& Mosley, 2003, p. 186-189. Veja também a clínica odontológica de Orlândia no livro originado da exposição "Encore Moderne? Architecture brésilienne 1928-2005”, apresentada na Cite de l'architecture et du patrimoine, em Paris, como parte das festividades do ano do Brasil na França (2005). Cf. CAVAlCANTI, L.; LAGO, A. C. do. Ainda Moderno? Arquitetura Brasileira Contemporânea. Rio de Janeiro, Editora Nova Fronteira, 2005, p. 88-91. 


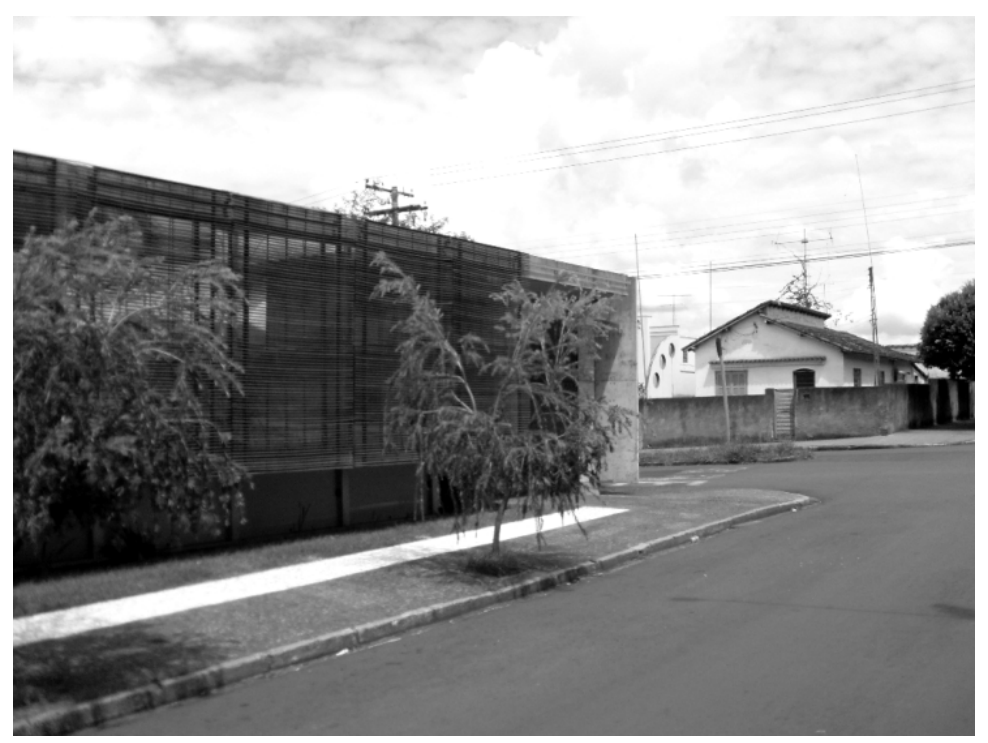

Figura 104 - Clínica de Odontologia, 1998-2000, edifício e entorno (1). Fonte: autor (mar. 2008).

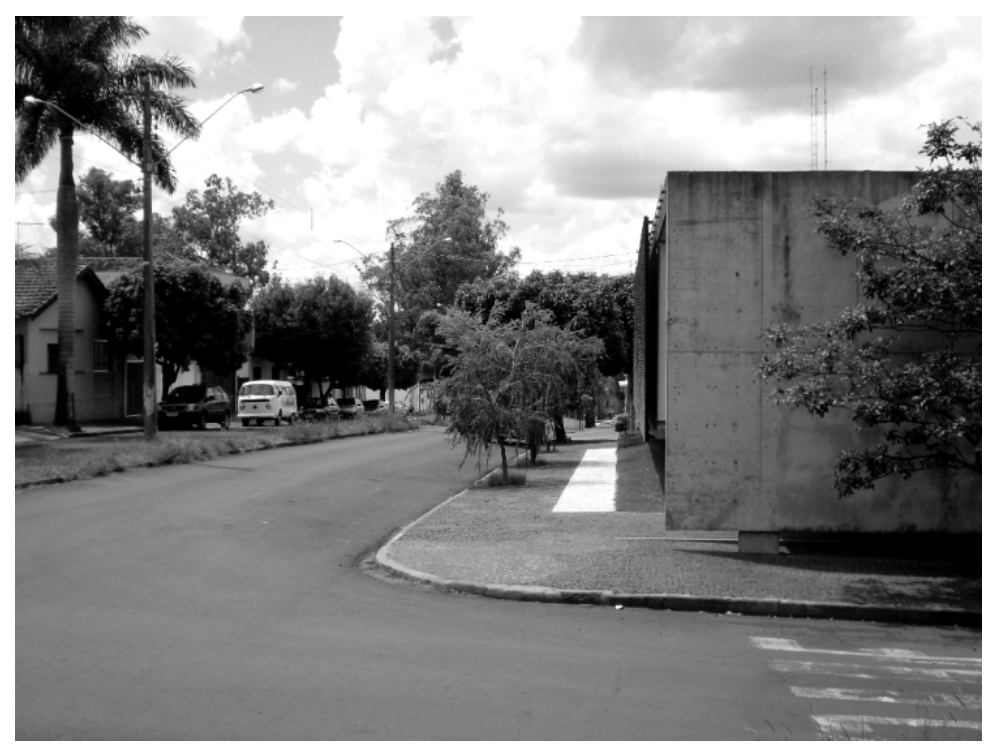

Figura 105 - Clínica de Odontologia, 1998-2000, edifício e entorno (2). Fonte: autor (mar. 2008).

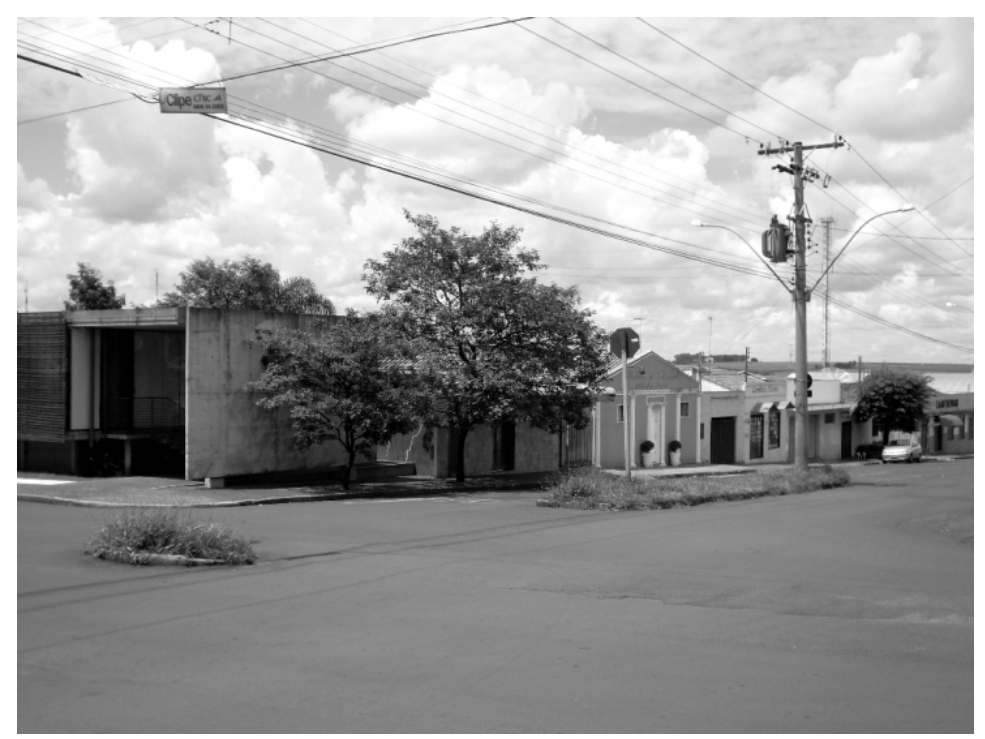

Figura 106 - Clínica de Odontologia, 1998-2000, edifício e entorno (3). Fonte: autor (mar. 2008). 
Considerando-se o exame desse edifício no ambiente em que está inserido, poderemos ampliar a necessária visão de conjunto para uma compreensão da obra e, assim, refletir sobre essa linhagem da "arquitetura paulista", explicitando suas conseqüências e transformações, na medida em que, na Clínica de Odontologia, o "modelo" é revisitado. Essa afirmação pode ser verificada nos croquis que esboçamos de alguns projetos realizados desde a década de 60 , onde a grande cobertura é uma estrutura marcante. Entretanto, nos anos 90, as questões que estão implícitas nessa configuração são outras.
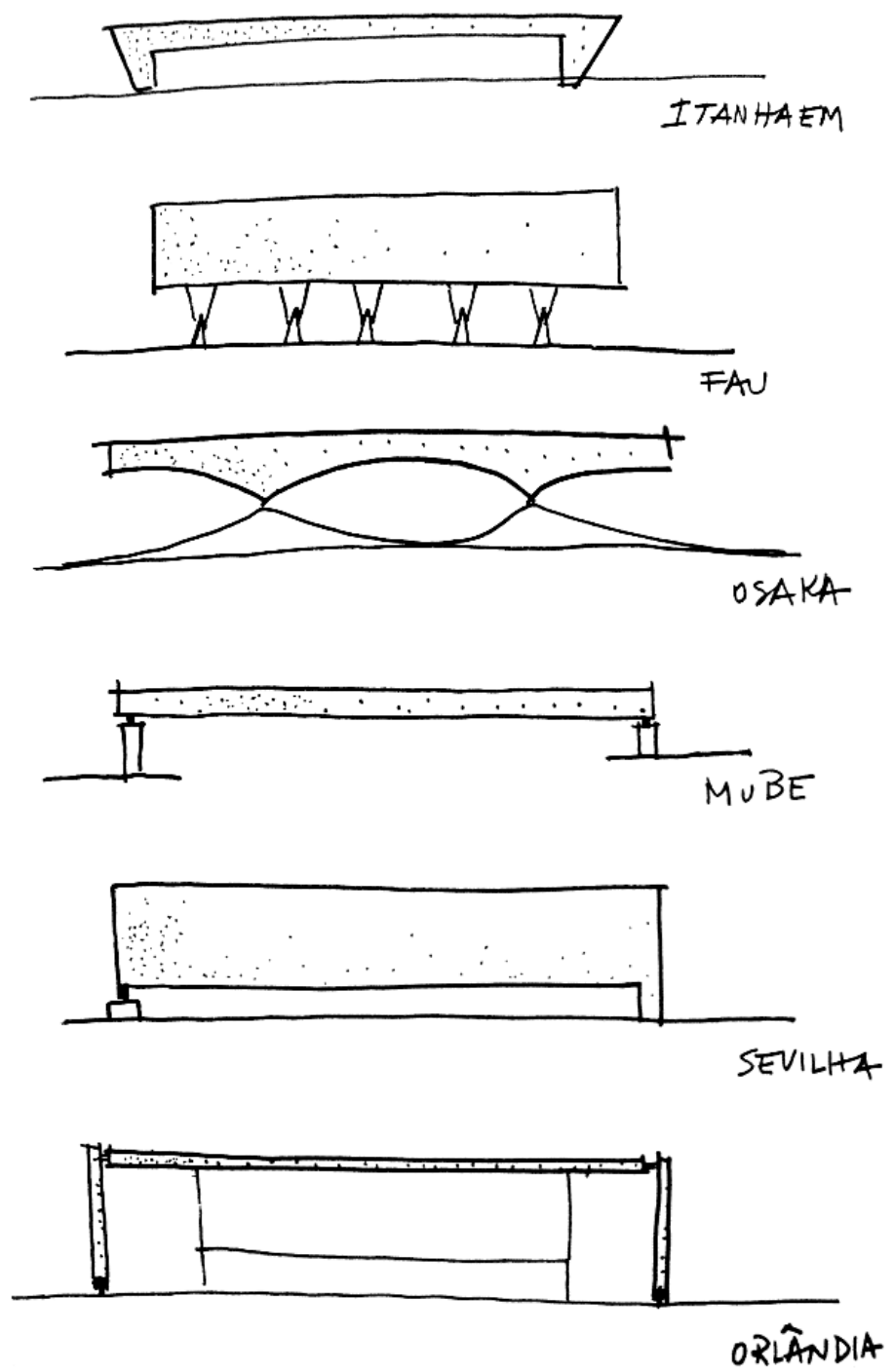

Figura 107 - Croquis : a grande cobertura dos 60 aos 90. Elaboração do autor (2008). 


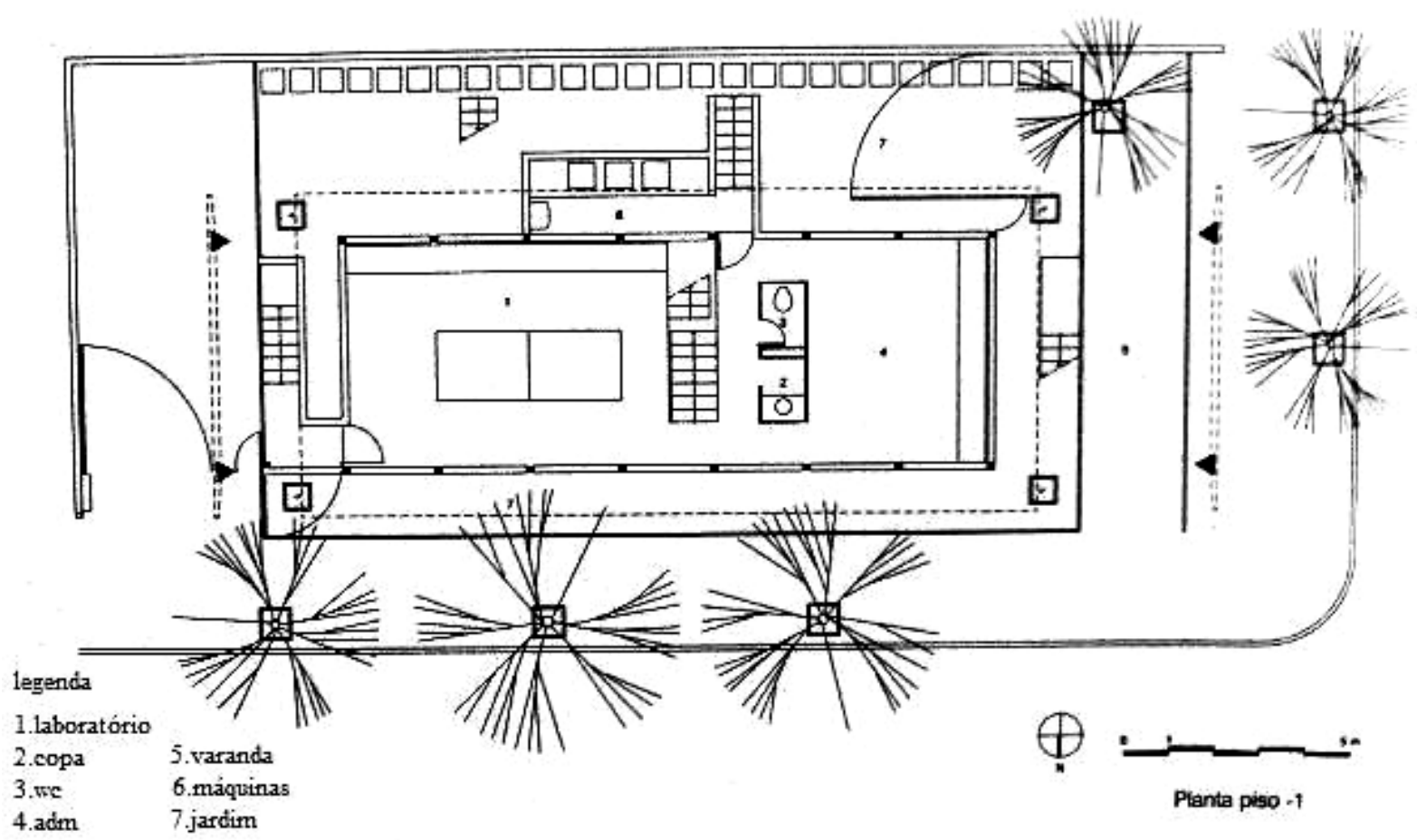

Figura 108 - Clínica de Odontologia, 1998-2000, projeto, planta nível (-1,48). Fonte: Escorial (2004, p. 38).

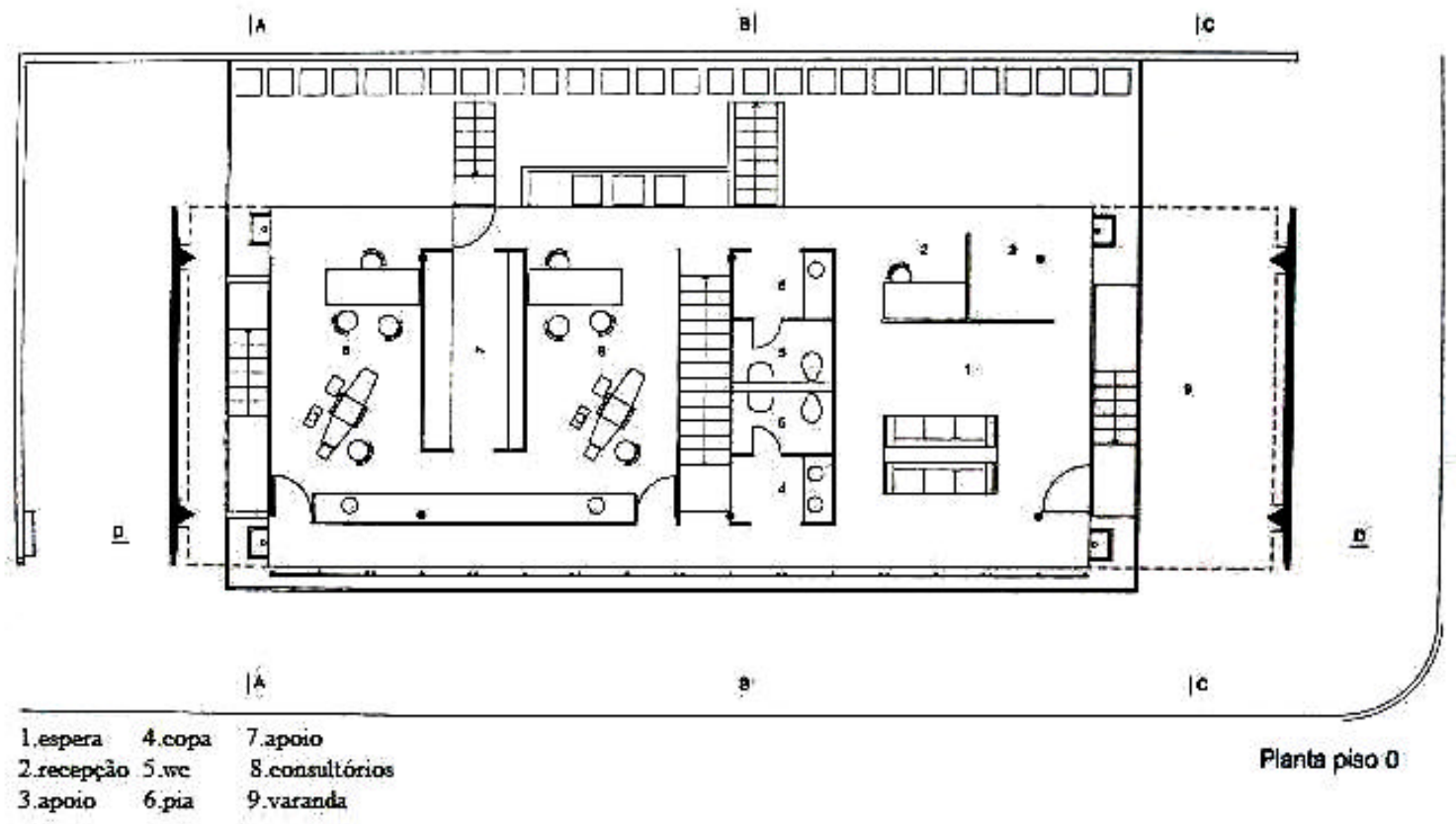

Figura 109 - Clínica de Odontologia, 1998-2000, projeto, planta nível (+1,12). Fonte: Escorial (2004, p. 38). 


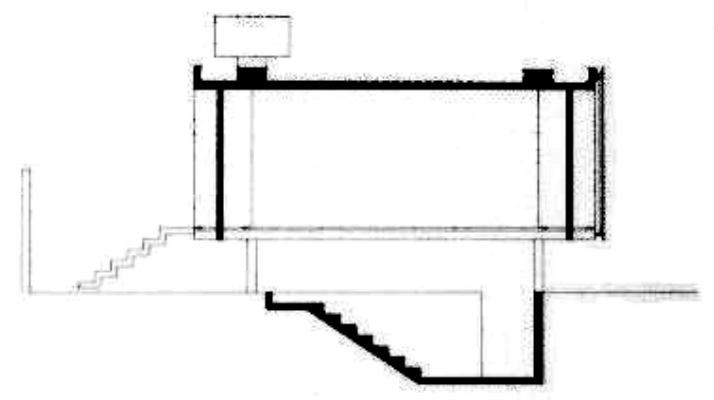

Corte A

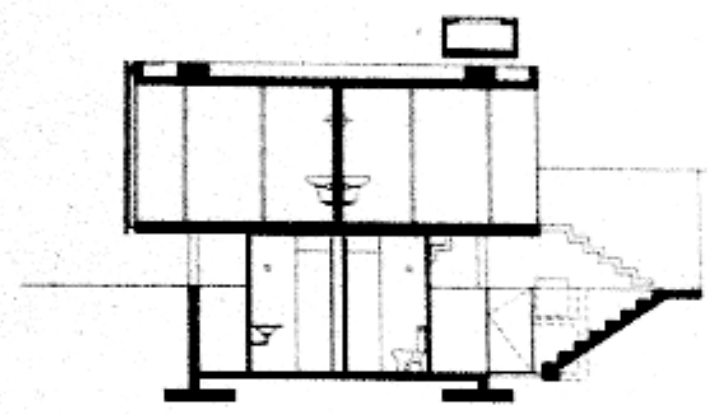

Corte B

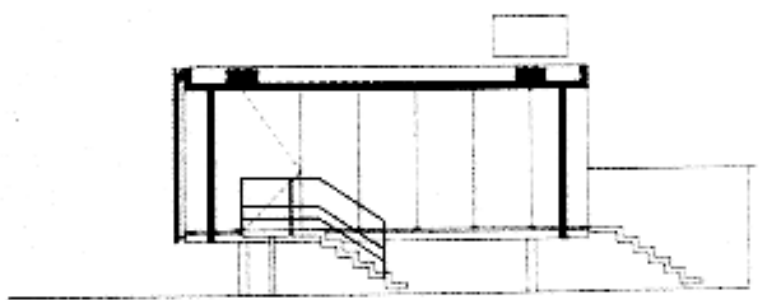

Corte C

Figura 110 - Clínica de Odontologia, 1998-2000, projeto, cortes. Fonte: Escorial (2004, p. 38). 


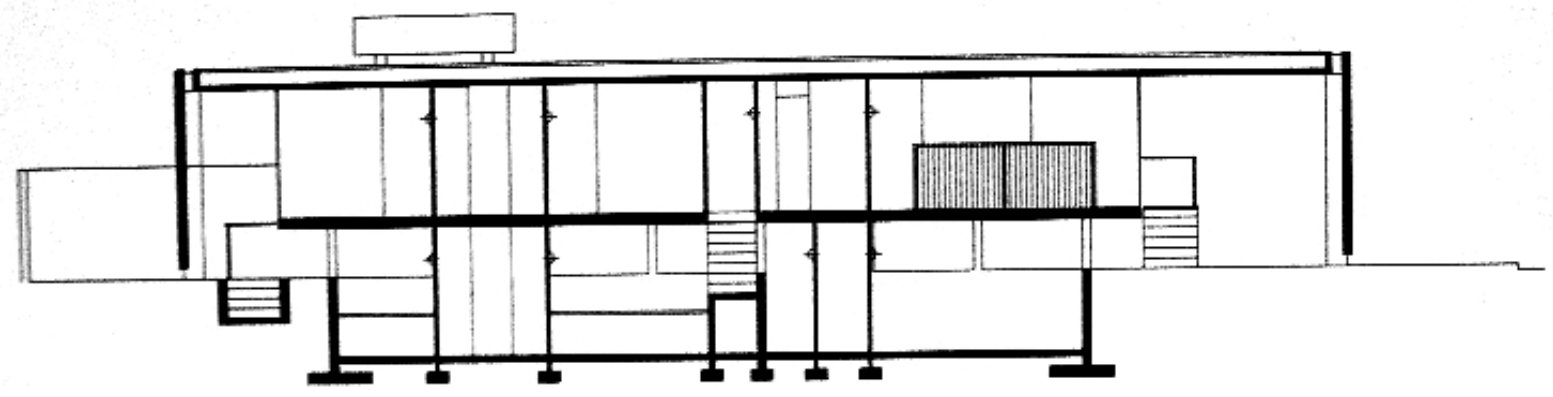

Corte D

Figura 111 - Clínica de Odontologia, 1998-2000, projeto, corte D. Fonte: Escorial (2004, p. 38).
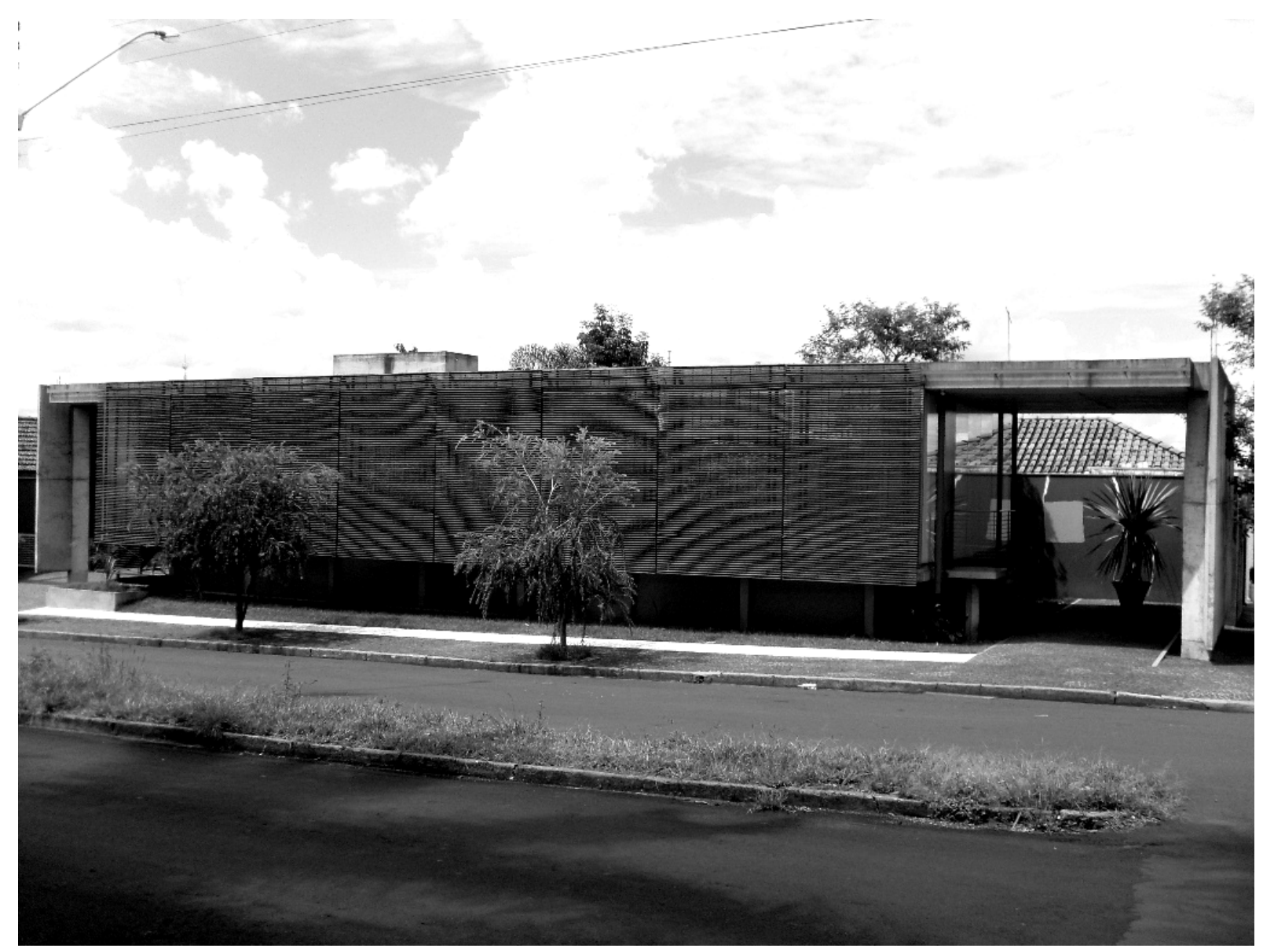

Figura 112 - Clínica de Odontologia, 1998-2000, exterior. Fonte: autor (mar. 2008). 
A tentativa do MMBB Arquitetos em estabelecer um diálogo com o entorno urbano é o nosso ponto de partida, pois esta clínica se localiza em uma esquina, como prédio sem muros, buscando construir, nas suas duas laterais, uma espécie de cobertura de concreto avarandada. Nessa concepção, o projeto prima em expandir os limites do lote, tanto que, ao fundo, é possível ter a impressão da configuração de um pequeno quintal ajardinado como uma continuação do recuo frontal.

Logo, em uma extremidade, procura-se a articulação de duas cotas, a da rua, com a varanda em continuidade com a calçada e a da ante-sala dos consultórios $(+1,12)$, por meio de uma espécie de alpendre que serve como acesso à edificação. Há, ainda, o laboratório de próteses que fica abaixo desse plano, parcialmente escavado $(-1,48)$. É, nessa conjugação de desníveis, que a equipe justifica o partido, na medida em que recupera uma "parte da memória das pessoas, acostumadas à cota alta dos assoalhos sobre porões das primeiras casas da cidade". 105

Nesse sentido, no programa dessa clínica de odontologia, existe uma tentativa de revalidar a varanda, o alpendre e o porão, a partir de uma leitura "contextualista" da arquitetura de Orlândia, cuja tipologia possibilitava desenhar uma suave transição entre a casa e a rua. A partir dessa concepção, o edifício busca certa permissividade nos trajetos, devido à ininterrupção do calçamento de mosaico português proposto como um piso que se distende para além dos limites da projeção da cobertura.

Além disso, uma relação entre interior-exterior também pode ser reforçada, pois, ao invés dos comuns embasamentos pétreos usados antigamente, a sustentação do piso superior dessa clínica odontológica se dá por meio de oito esbeltos pilares de concreto, entremeados por panos de vidro, criando uma linha cristalina e fazendo com que o corpo do edifício pareça

\footnotetext{
${ }^{105}$ BUCCI, A. Depoimento a Fernando Serapião. SERAPIÃO, F. Complexa concepção construtiva é ocultada pela simplicidade volumétrica. (Clínica de Odontologia). Projeto, São Paulo, n. 248, p. 76-81, out. 2000, p. 78.
} 
flutuar. Com essa preocupação, busca-se uma perspectiva fluída do sítio, além da configuração de dispositivos para iluminação das funções que estão semi-enterradas no terreno. Uma transparência acentuada pelas superfícies diáfanas que recobrem os quatro lados do volume suspenso que é apenas tangenciado pela estrutura delgada de concreto armado.
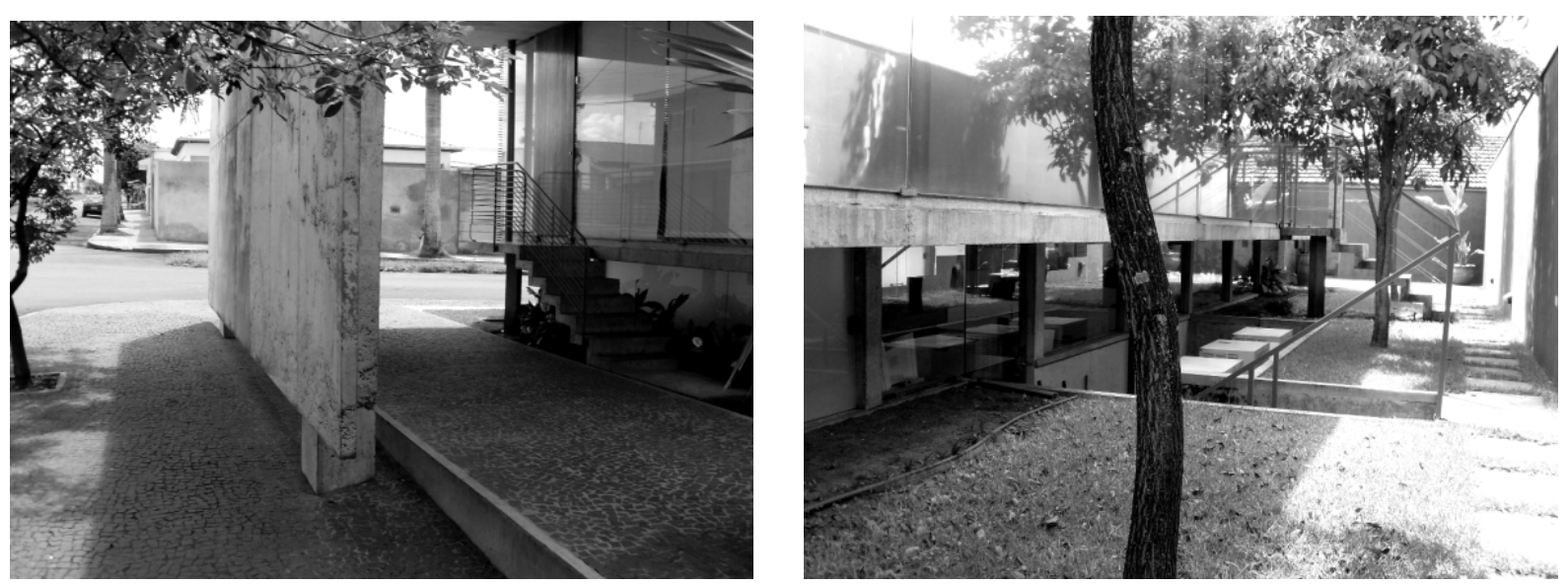

Figura 113 e 114 - Clínica de Odontologia, 1998-2000, recuos integrados. Fonte: autor (mar. 2008).

Porém, para amenizar a incidência de raios solares na fachada norte da clínica de odontologia e evitar a perda de interação entre passeio e edifício, proporcionada pelos panos de vidro, recorre-se ao uso de um sistema de brise-soleil de madeira. A utilização desse ripado pode fazer referência à "arquitetura colonial”, como diz Guerra (2004) ${ }^{106}$, entretanto, se os antigos muxarabis possibilitavam a ventilação natural, agora, os filetes, sobrepostos com certo distanciamento dessa grande vidraça, sob um trilho de metal que corre sobre a estrutura, já não a permite. ${ }^{107}$

\footnotetext{
${ }^{106}$ GUERRA, A. Quatro projetos do grupo MMBB. Vitruvius. Disponível em: <http://www.vitruvius.com.br/arquitextos/arq056/arq056_02.asp>. 2004. Acesso em: 07 nov. 2007, p.03.

107 No passado paulista esses dispositivos de controle de insolação aparecem em casas do chamado "período wrightiano" de Artigas, embora com uma linguagem diferente. Cf. BRUAND, Y. Arquitetura Contemporânea no Brasil. São Paulo, Perspectiva, 1981, p. 271. No entanto, ressaltamos que a utilização de elementos recorrentes da arquitetura tradicional para controlar as condições climáticas, como muxarabis, venezianas, beirais, varandas e outras soluções simples do repertório construtivo brasileiro foram usadas em outros projetos de Ângelo Bucci e Álvaro Puntoni, tal como a Pousada em Juquehy. Cf. MUNGIOLI, A. (Ed.). Planos desencontrados, anteparos verticais, varandas, muxarabis, venezianas e beirais controlam a luz e o ar. (Pousada em Juquehy). Projeto, São Paulo, n. 207, p. 46-50, abr. 1997.
} 

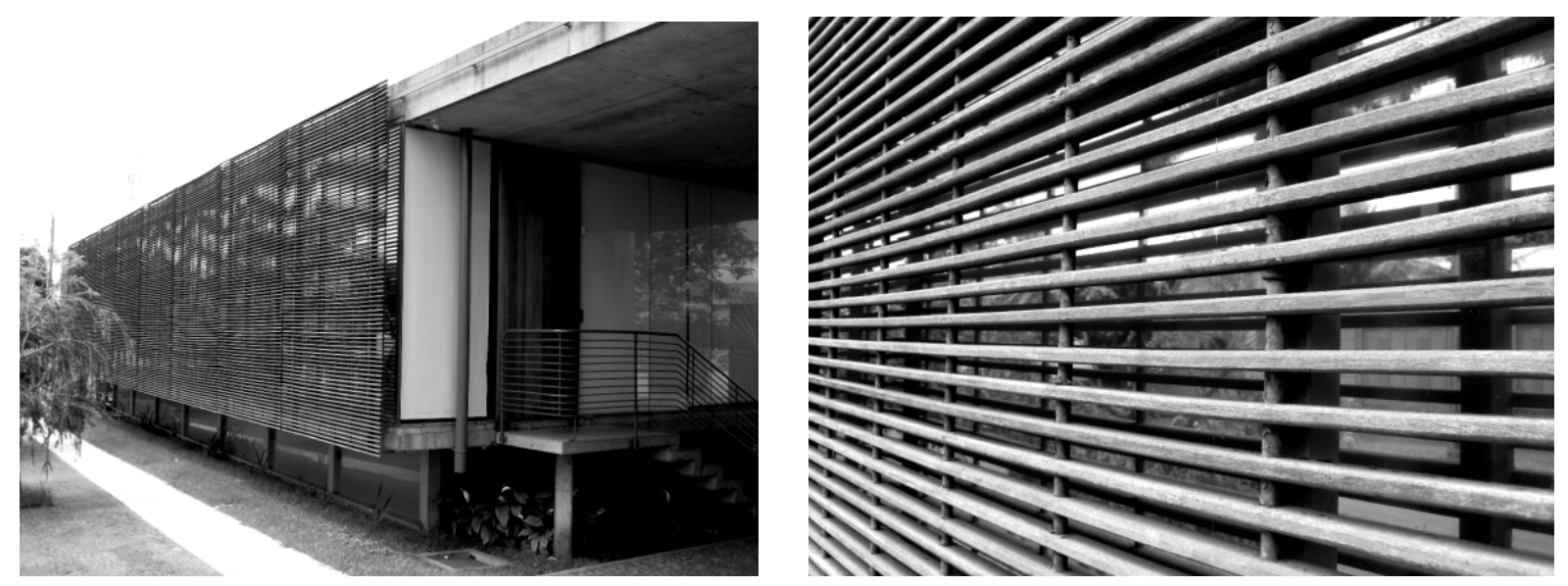

Figura 115 e 116 - Clínica de Odontologia, 1998-2000, exterior, brises de madeira. Fonte: autor (mar. 2008).
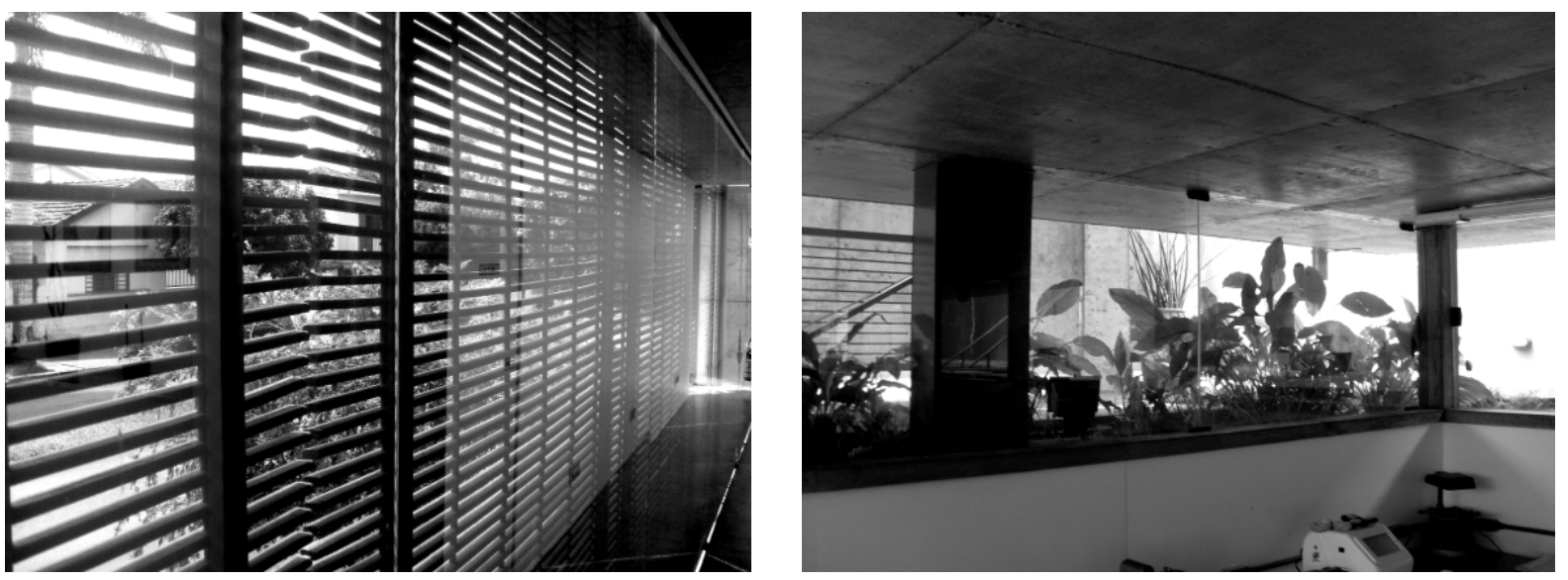

Figura 117 e 118 - Clínica de Odontologia, 1998-2000, interior, transparências. Fonte: autor (mar. 2008).
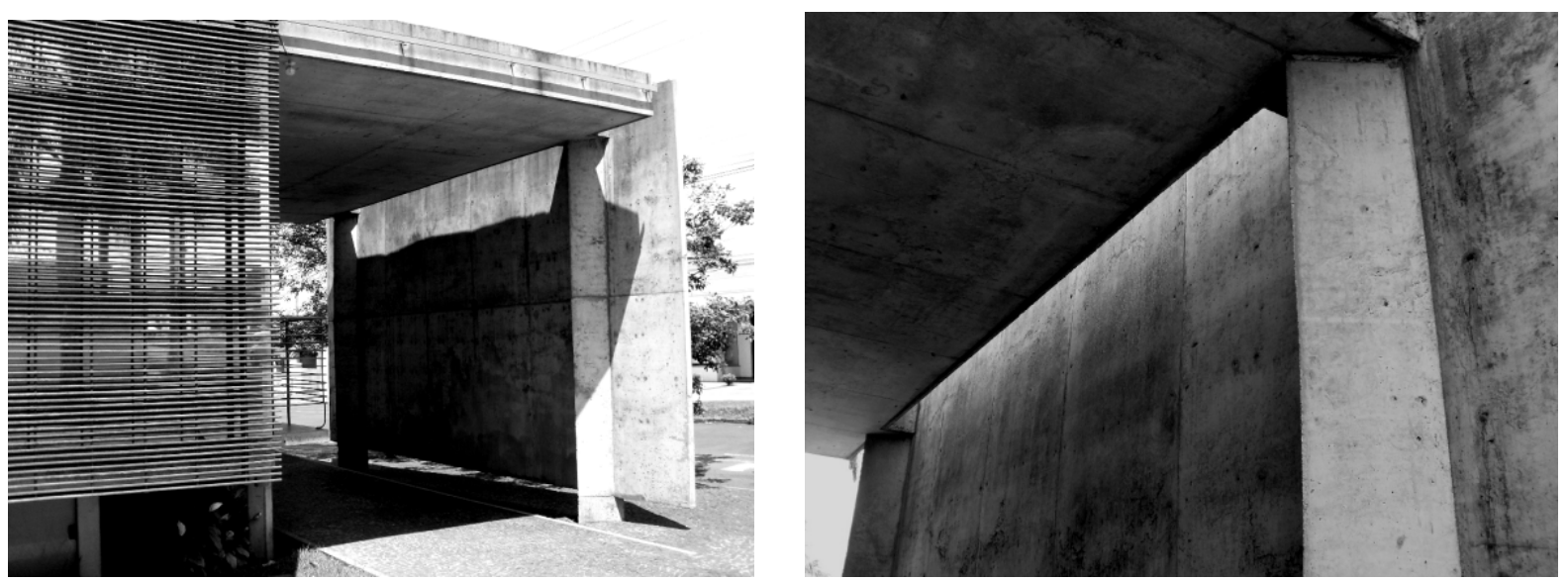

Figura 119 e 120 - Clínica de Odontologia, 1998-2000, estrutura, vértices de luz. Fonte: autor (mar. 2008). 
Mesmo assim, a apropriação dos materiais utilizados no projeto não compromete a translucidez da clínica. Nesse caso, esse edifício de concepção pavilhonar prima por conjeturar uma continuidade espacial com seu ambiente. Em conjunto, os fechamentos transparentes, a estrutura singela e as ripas de madeira entremeadas tendem a revelar um desejo de integração entre obra e espaço urbano, expressa no interesse em "desenhar a cidade e não só um objeto". ${ }^{108}$ Contudo, esse discurso não contempla uma postura política crítica frente aos contrastes sócio-econômicos que circundam essa construção.

Nesse caso, o jogo de transparências e a aparente leveza estrutural, presentes nesta obra, talvez promovam o contrário, ou seja, um desprendimento desse edifício do seu contexto. Nesse raciocínio, os pilares do prédio, de seção triangular, mal tocam a terra, enquanto as empenas de concreto armado descolam-se, virtualmente, nos quatro cantos da edificação - nas intersecções com o teto e o chão -, produzindo vértices como frestas de luz. Com o sol a pino, o esqueleto parece estar levitando, fora do lócus. As hastes metálicas engastadas nas duas vigas invertidas da cobertura também colaboram para esse efeito, na medida em que sustentam o piso envidraçado da espera e consultórios, como uma plataforma flutuante.

Deste modo, apesar da grande cobertura se distender de um lado ao outro do terreno com grande desenvoltura, se mantém como um plano independente, pois já não pode abrigar um espaço de sociabilização, pela própria natureza do programa. Além do que, o caráter técnico da construção não decorre da premissa de democratização dos métodos construtivos. Em prejuízo do projeto coletivo que levou à opção pelas formas nuas, a economia de meios se

\footnotetext{
108 FRANCO, F. M. Depoimento a John E. Czarneck. CZARnECKI, J. E. Dental Clinic, Orlandia, Brazil. Architectural Record, p. 140-143, jul. 2002, p. 140. (tradução do autor).
} 
atém, agora, a uma ratificação da forma pura, sublimada em favor do que ainda se tem: a técnica, como saída que restou frente aos desajustes da industrialização da construção. ${ }^{109}$

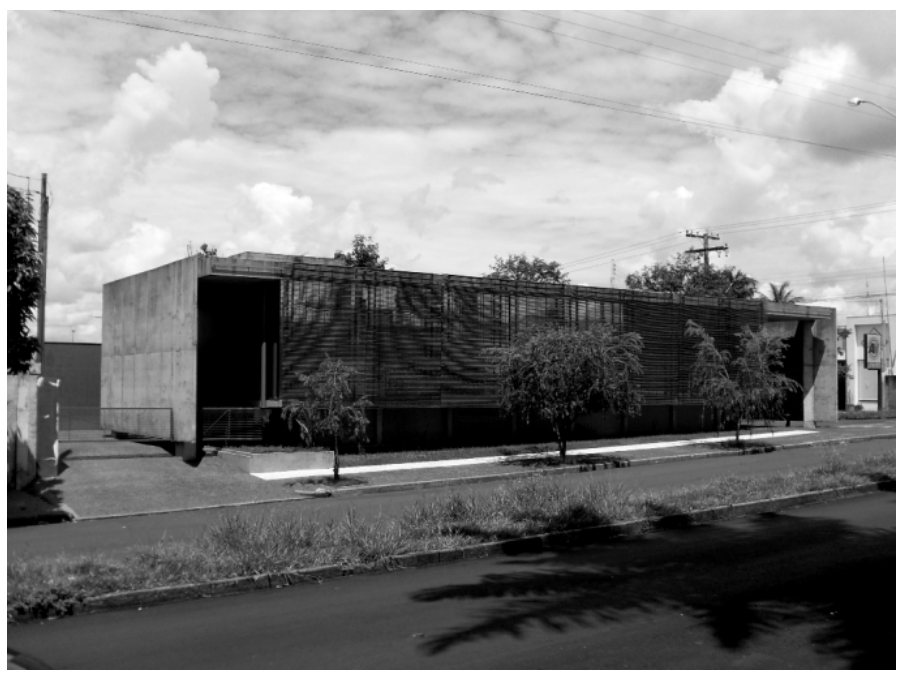

Figura 121 - Clínica de Odontologia, 1998-2000, exterior, vista (1). Fonte: autor (mar. 2008).

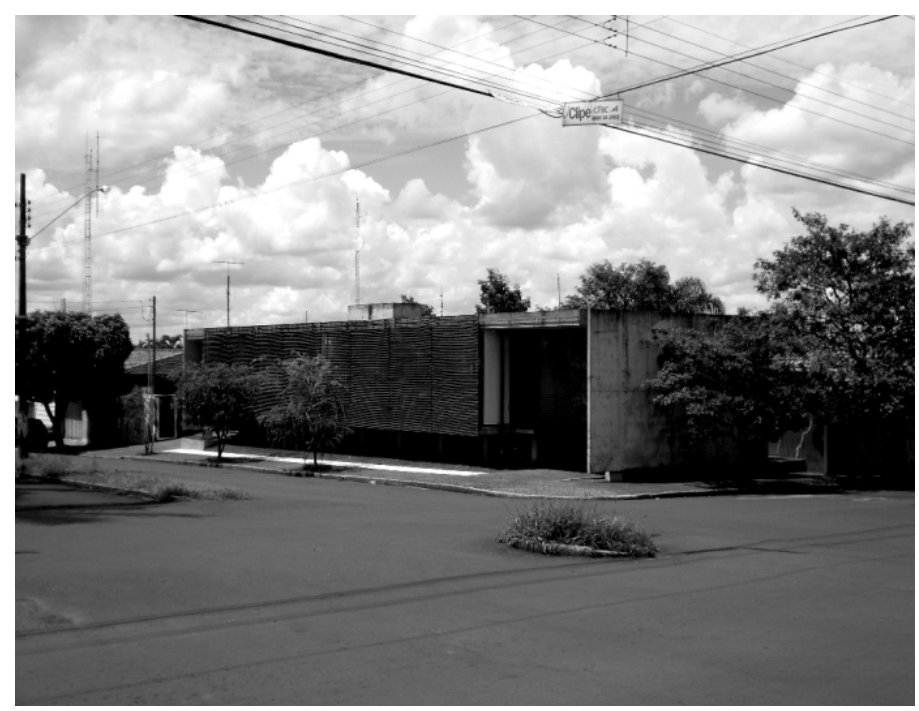

Figura 122 - Clínica de Odontologia, 1998-2000, exterior, vista (2). Fonte: autor (mar. 2008).

\footnotetext{
109 Atualmente, as tentativas de construção com ele mentos pré-moldados colaboram para subverter a posição política que a forma nua, como resultado da economia de meios, tinha no passado paulista. Os esqueletos produzidos em escala industrial servem para acelerar o processo construtivo, mas, ao mesmo tempo, são recobertos por painéis que escamoteiam sua baixa qualidade e aparência "tosca" tendo em vista a valorização plástica do conjunto. Cf. GIMENEZ, L. E. As quatro escolas do FDE em Campinas. Arquitextos n. 064. Portal Vitruvius. Disponível em:

<http://www.vitruvius.com.br/arquitextos/arq064/arq064_2.asp>. 2005. Acesso em: 21 ago. 2007.

Além disso, as peças pré-fabricadas redundam num maior gasto, na medida em que seus componentes são superdimensionados, não se adaptando às soluções mais simples, visto que o seu preço é ajustado pela quantidade de concreto utilizado. Uma situação que faz das estruturas industrializadas nem sempre as mais adequadas às saídas que visam o barateamento da construção. (Faço referência às empresas do ramo, às quais, por ocasião dessa pesquisa, consultamos).
} 
No entanto, no projeto da clinica de Orlândia, a utilização da técnica do concreto armado não almeja uma contribuição para o mundo contemporâneo. Muito embora seja parte da crença em uma experimentação criativa, continua a ser produzida mediante as potencialidades de uma "tecnologia acessível", como reitera um argumento de Adriá (2005). ${ }^{110}$ Nessa leitura, a técnica do concreto armado pode manter a expressividade que estava presente na chamada "arquitetura paulista", mas antes de sustentar o seu posicionamento crítico diante dos descompassos existentes na realidade brasileira, opera como uma solução estético-formal.

Dessa maneira, o paradoxo é que, do ponto de vista técnico, a linguagem pensada em um plano estético-formal, com relação ao uso do concreto armado, caminha para um estágio cada vez mais artesanal, no sentido de uma arquitetura de caso único, singular, direcionandose no sentido oposto àquele imaginado nos experimentos de Artigas, já que não houve a qualificação de mão-de-obra, nem a alteração dos meios de produção no canteiro, mas um incremento das sujeições. ${ }^{111}$

Assim, esta bela obra construída na cidade de Orlândia nos mostra, em termos técnicos e produtivos, a aceitação dos embaraços que já estavam demonstrados nos projetos anteriormente mencionados. Assim, o que era uma reflexão sobre a Forma na arquitetura, incorporando a técnica, em uma luta política perante as contradições do país, com o intuito de

\footnotetext{
110 ADRIÁ, M. Latin America's Constructed Architecture. In: EDITORS of Phaidon Press. 10.10_2: 100 architects, 10 critics. Nova Iorque, Phaidon, 2005, p. 409. (tradução do autor). O livro no qual está incluído esse texto apresenta a Clínica de Odontologia de Orlândia junto de outros projetos contemporâneos do mundo todo. $\mathrm{O}$ artigo em específico faz menção às obras construídas por arquitetos latino-americanos, incluindo Ângelo Bucci. Vale ressaltar que, as únicas obras brasileiras, incluídas nesse importante compêndio são de autoria do MMBB Arquitetos.

${ }_{111} \mathrm{O}$ arquiteto Ângelo Bucci explica que para fazer as obras de Orlândia, a $400 \mathrm{~km}$ de São Paulo, tinha que desenhar à distância, porque o que recebia pelos projetos não pagava as viagens até sua cidade natal. Essa condição lhe ensinou a ser "sucinto" e a "não distrair o olho do mestre-de-obras com desenhos que não fossem imprescindíveis". Cf. BUCCI, A. Um Arquiteto em busca de Razões. [Entrevista concedida a Valentina Figuerola ]. Projeto, São Paulo, n. 137, p. 82-84, ago. 2005, p. 82.
} 
colaborar para o avanço da sociedade, resulta, hoje, na tradução da forma da arquitetura enquanto argúcia estética, o que, diante de uma herança, revela a beleza como impasse.

Mais do que antes, as mazelas ainda "pupulam" em meio às soluções elegantes de projetos como o dessa clínica odontológica. Todavia, mesmo diante dos desajustes imbricados no campo social, técnico e econômico do país, os contornos exuberantes de obras como essas ganham cada vez mais destaque. ${ }^{112}$ Nesse caso, tendo em vista o que sugere Arantes (1997) sobre o lugar da arquitetura em um momento em que o Estado, a economia e a sociedade estão sendo desmanchados "[...] na mesma velocidade em que se move o capital”, o nosso “acervo" também passa a ser desmontado em “imagens" sem referentes. ${ }^{113}$

Nesses termos, diferentemente da década de 50, quando Artigas postulou a sua atitude crítica em face da realidade, mesmo sem ter conseguido estender as benesses que estavam por detrás de suas premissas, aproveitou um momento difícil para dar um salto cultural na produção da arquitetura. No entanto, o projeto dessa clínica não é capaz de ser o resultado de um pensamento sincrônico que possa traduzir um aprendizado sobre o passado e, assim,

${ }^{112}$ Confira algumas publicações internacionais do projeto da clínica odontológica de Orlândia do MMBB Arquitetos:

CZARNECKI, J. E Dental Clinic, Orlandia, Brazil. Architectural Record, p. 140-143, jul. 2002, p. 140.

BRAGA, M. MMBB arquitetos. ARQ, Santiago, n. 51, p. 22-27, jul. 2002. Scielo.cl. Disponível em: 〈http://www.scielo.cl/pdf/arq/n51/art09.pdf >. jul. 2002. Acesso em: 23 jan. 2009.

BARDA, M. Clinica Odontoiatrica. Abitare, Milão, n. 421, p. 216-219, out. 2002.

GUERRA, A. Quattro Progetti del gruppo MMBB. Casabella, Milão, n. 723, p. 31-47, jun. 2004. ESCORIAL, L. E. (Ed.). Clínica de Odontologia spbr arquitetos. ARQ./A, Lisboa, n. 26, p. 37-41, jul./ago. 2004. ANDREOLLI, E.; FORTY, A. Projetos recentes: estudos de caso. In: A NDREOLLI, E.; FORTY, A. Arquitetura Moderna Brasileira. Londres, Phaidon, 2004. p. 204-222. EDITORS of Phaidon Press. SPBR. In: EDITORS of Phaidon Press. 10.10_2: 100 architects, 10 critics. Nova Iorque, Phaidon, 2005, p. 356-359.

113 ARANTES, O. B. F. Lúcio Costa e a "Boa Causa" da Arquitetura Moderna. In: ARANTES, O. B. F.; ARANTES, P. E. Sentido da Formação. São Paulo, Paz e Terra, 1997, p. 132. De acordo com Lara (2000), se até os anos 1930, éramos apenas consumidores de uma modernidade incipiente, logo depois passamos a produtores periféricos de um modernismo elegante. No entanto, com o golpe militar e durante os anos 1970, nossa arquitetura entra em crise e se isola. Nesse rumo, na década de 1980, novamente nos transformamos em consumidores, mas, agora, de pós-modernismos. Porém, nos últimos tempos, fomos re-descobertos pelos periódicos internacionais com "gosto de revivalismo". "[...] Os caminhos da imagem da arquitetura brasileira nesse século, aqui dentro e lá fora, funcionam como um jogo de espelhos que refletem e refratam ao mesmo tempo. Refletem no sentido de espelhar à distância aquilo que aqui acontece, desenvolvendo imagens locais dentro de uma moldura de legitimação. Mas deve-se notar que toda imagem no espelho é invertida [...]. [...] Assim, a imagem refletida é também sempre refratada, deslocada, desviada, distorcida." Cf. LARA, F. Espelho de fora: a arquitetura brasileira vista do exterior. Vitruvius. Disponível em:

<http://www.vitruvius.com.br/arquitextos/arq000/esp012.asp>. 2000. Acesso em: 29 jun. 2006, p. 01-02. 
enfrentar o momento presente que vivemos no Brasil, caracterizado, de acordo com os argumentos de Oliveira (2003), por uma "acumulação truncada" em uma "sociedade desigualitária sem remissão". ${ }^{114}$

Sob essa condição, acreditamos que o belo projeto da Clínica de Odontologia de Orlândia é emblemático para compreender as transformações da "arquitetura paulista" recente, já que a sua conformação estético-formal carece de sentido político crítico perante as deficiências reveladas nas ambigüidades de um país construído às avessas. Desse modo, é plausível que todo o conjunto esteja suspenso da quadrícula dessa cidade do interior paulista, na medida em que subjuga nossa realidade em favor da apropriação do "know-how" de um repertório, transformando o "modelo" em imagem de si mesmo.

Sendo assim, se por um lado, o fato dessa clínica de odontologia ser veiculada na mídia especializada revela esse contra-senso, por outro, em face das nossas inúmeras discrepâncias, inclusive técnicas, é mais precisamente no domínio impresso que essa obra se realiza plenamente, porque seu ambiente urbano e as agruras sociais nele presentes podem ser suprimidos. Como sugere Jameson (1997), nas fotos, a arquitetura é "reificada" pela “[...] substituição ilícita de uma ordem de coisas por outra [...]”. Logo, as revistas nos fazem crer que as imagens fotográficas de edifícios são "a coisa em si”. 115

Nas fotografias noturnas que foram divulgadas por alguns periódicos, ao final da construção desse projeto em Orlândia, essa noção é evidente. Ao inverso da grossura e do peso do concreto - que no passado paulista atestava não apenas as falhas dos meios técnicos, mas também as reais condições de produção na construção civil -, certo grau de

\footnotetext{
114 OLIVEIRA, F. O Ornitorrinco. In: OLIVEIRA, F. Crítica à razão dualista - O ornitorrinco. São Paulo, Boitempo, 2003, p. 150. "[...] não há possibilidade de permanecermos como subdesenvolvido e aproveitar as brechas que a Segunda Revolução Industrial propiciava; não há possibilidade de avançar, no sentido da acumulação digital-molecular: as bases internas da acumulação são insuficientes, estão aquém das necessidades para uma ruptura desse porte. Restam apenas as "acumulações primitivas" [...]".

${ }_{115}$ JAMESON, F. Pós-Modernismo: A lógica cultural do capitalismo tardio. São Paulo, Ática, 1997, p. 144.
} 
desmaterialização do edifício é potencializado. O embasamento do prédio se ilumina, enquanto seu volume principal surge como uma massa etérea de luz. Nessas condições, essa obra pode ser entendida como miragem.

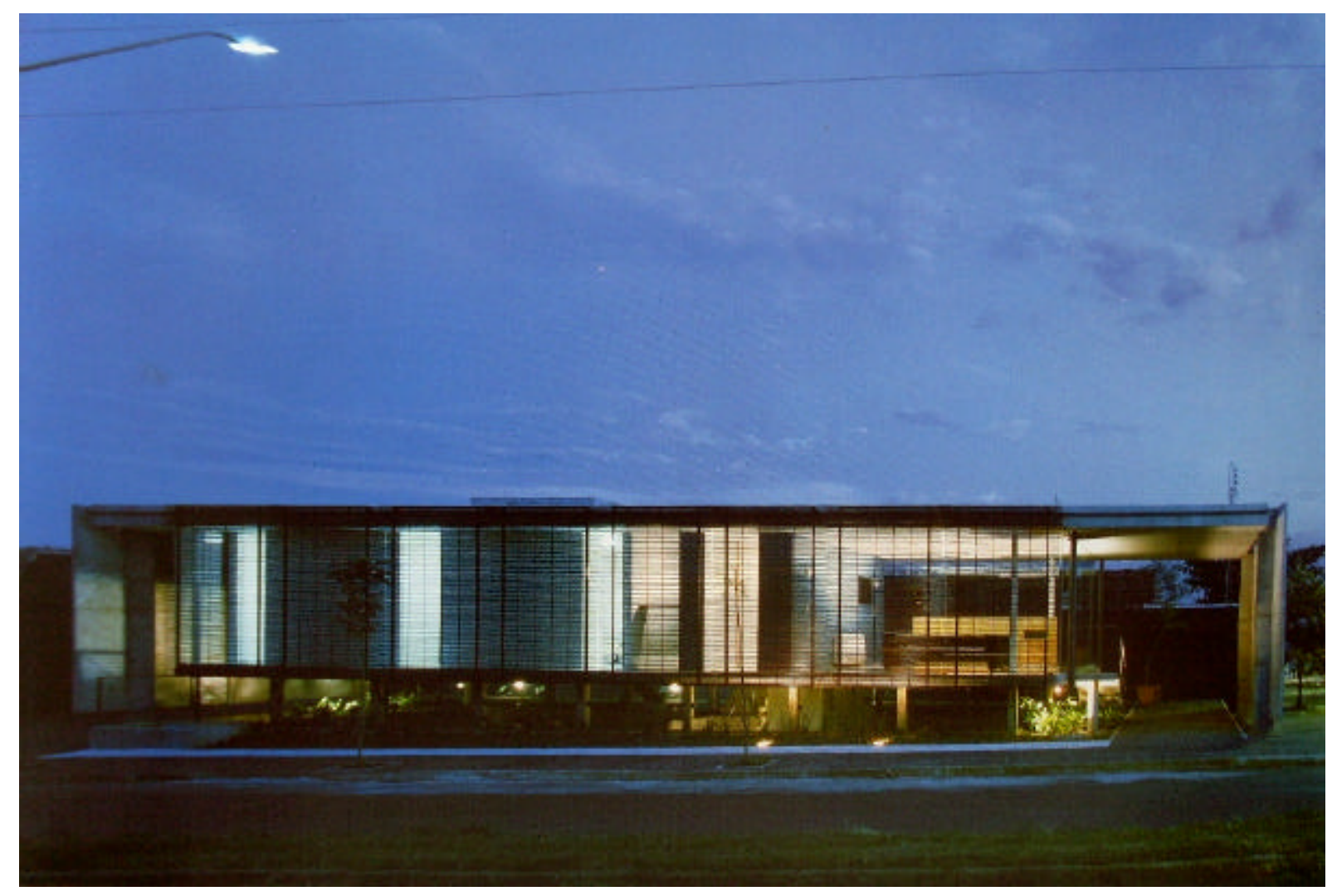

Figura 123 - Clínica de Odontologia, 1998-2000, exterior à noite (foto de Nelson Kon). Fonte: Escorial (2004, p. 37). 


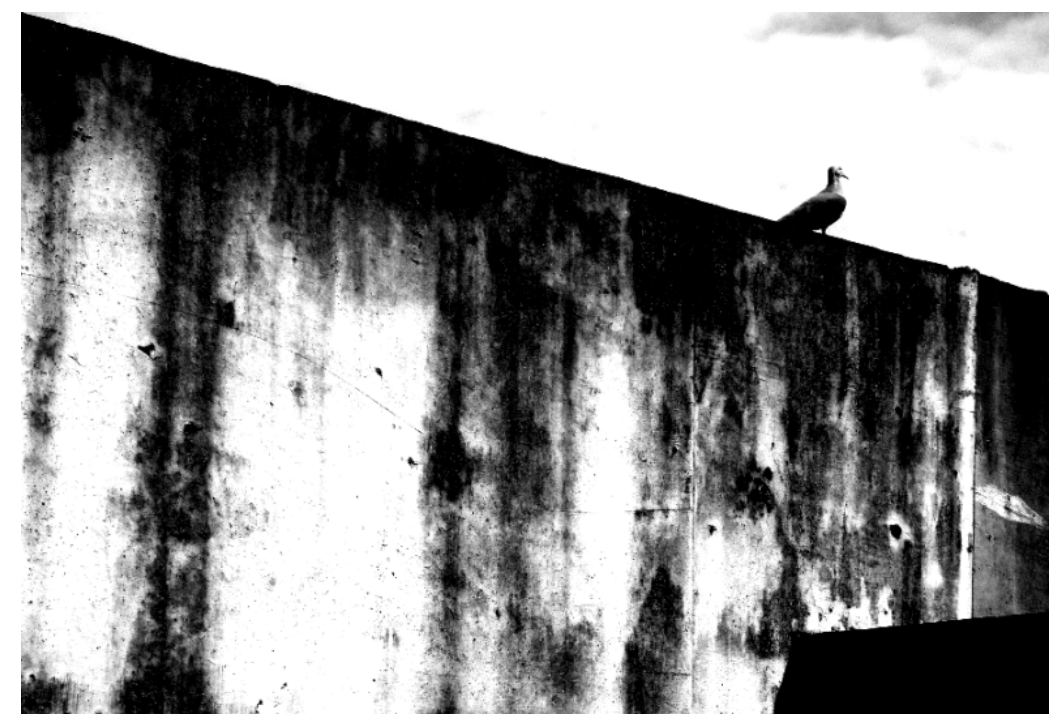

ALGUMAS CONSIDERAÇÕES SOBRE A MUDANÇA DE SENTIDO DA ARQUITETURA 
Os últimos projetos aqui estudados demonstram como os pressupostos políticos arraigados à constituição da "arquitetura paulista" nos anos 50 se arrefecem, na medida em que as suas implicações estéticas se sobressaltam em relação às preocupações políticas. Nesse sentido, a afirmação de um repertório, outrora consolidado, se dá pelo âmbito formal, na medida em que sobrepuja uma abrangência política, econômica e social da arquitetura, colaborando para a criação de imagens.

Entretanto, essa visão sobre a produção paulista recente não é hegemônica, visto a quantidade de matérias publicadas em revistas nacionais e internacionais, enaltecendo essas e outras obras contemporâneas. Porém, é preciso levar em conta uma reflexão sobre o papel que a mídia e o mercado desempenham em nossos dias, na difusão e na ratificação da arquitetura ante uma eleição de formas esvaziadas de pressupostos, as quais, na maioria das vezes, servem para a manutenção do status quo.

Desse ponto de vista, em decorrência dos interesses que comandam a lógica do lucro na construção civil, os arquitetos estão rotineiramente sujeitos às formalizações. $\mathrm{O}$ que, em parte, se deve ao fato do declínio das solicitações do Estado e de agentes que, em um momento anterior, eram capazes de fomentar o papel cultural da arquitetura, mas, sobretudo, à própria falta de posicionamento político crítico em face da nova realidade sócio-econômica.

O caso é que, mais do que antes, o trabalho do arquiteto se circunscreve às obras particulares. Estas, frequentemente, são o resultado de um "negócio" que impede uma efetiva ação do profissional, tornando o projeto parte de um jogo financeiro que não está sob o seu comando ou, quando está, serve para a adição de soluções estéticas exclusivas que se distanciam do papel que, no passado paulista, o desenho inclusivo da economia de meios desempenhava no horizonte social. 
Além disso, as defasagens materiais e tecnológicas, decorrentes de uma posição econômica desfavorável do país, fazem com que as técnicas construtivas mais utilizadas na execução de edifícios de baixo custo continuem sendo a alvenaria e os métodos alternativos. Assim, devido ao seu alto preço, os processos construtivos mecanizados estão a serviço dos projetos do capital e a técnica do concreto armado segue como solução artesanal, revelando a beleza da estrutura em obras, quase sempre, destinadas às classes mais favorecidas.

Nesse caso, a arquitetura precisa e austera de antes ganha seus novos contornos que já não são o da democratização dos recursos, da técnica como campo de provas para a atenuação dos disparates sociais e o da crítica - que poderia ser produzida hoje como posicionamento frente os desajustes ocasionados pela vinculação do Brasil ao léxico neoliberal. Ao contrário, as nuances mais características da conjuntura atual, somadas ao desmonte das políticas sociais, agora contribuem para uma estetização de toda a ordem, também evidenciada em relação à chamada "arquitetura paulista" em uma transformação do "modelo" em imagem de si mesmo.

Embora esvaziados de conteúdo político, alguns projetos recentes ainda mantém o domínio da prática e, por serem amplamente divulgados por meio das publicações especializadas, passam a ser referência para as novas gerações. Entretanto, como docentes, frequentemente nos deparamos com jovens que assimilam gratuitamente as "imagens" veiculadas pelos periódicos. O que não sugere que o método de ensino e aprendizagem não implique em juízo crítico, mas que, talvez, sofra um corte pelas imposições de um exercício profissional cada vez mais comercial.

Porém, o que a atitude crítica em face da realidade de contrastes dos anos 50 nos ensina é que, apesar das adversidades, é possível manter uma postura política, visando uma arquitetura que não seja comprometida, apenas, com os valores estéticos e programáticos de 
uma imagem arquitetônica, mas com a constituição de princípios capazes de retomar um pensamento cultural crítico ao projeto arquitetônico. Tal posição implica, inclusive, em admitir as limitações da arquitetura diante dos contra-sensos que nos cercam, já que são conjunturais, tomando proporções continentais perante os novos termos da marcha capitalista.

Diante disso, não estamos defendendo que não haja nada por fazer, ao contrário. O que defendemos é a construção de pressupostos políticos críticos no trabalho do profissional, frente à crise que se verifica na produção da arquitetura contemporânea, caracterizada, dentre outros fatores, pelo apelo midiático e mercadológico. Assim, é preciso que o arquiteto volte a considerar um engajamento político e sua necessária relação com a arquitetura para que possamos tomar parte dos processos decisórios e das questões que nos afligem.

Isso significa uma retomada de consciência sobre as incongruências do nosso tempo para que, de algum modo, os pressupostos sociais, técnicos e econômicos possam se refletir no projeto, contribuindo para sua viabilidade democrática e melhoria das condições de vida da maior parte da sociedade brasileira. Um pensamento sincrônico que nos capacite a enfrentar a prática projetual e, assim, novamente buscar o sentido da arquitetura. 


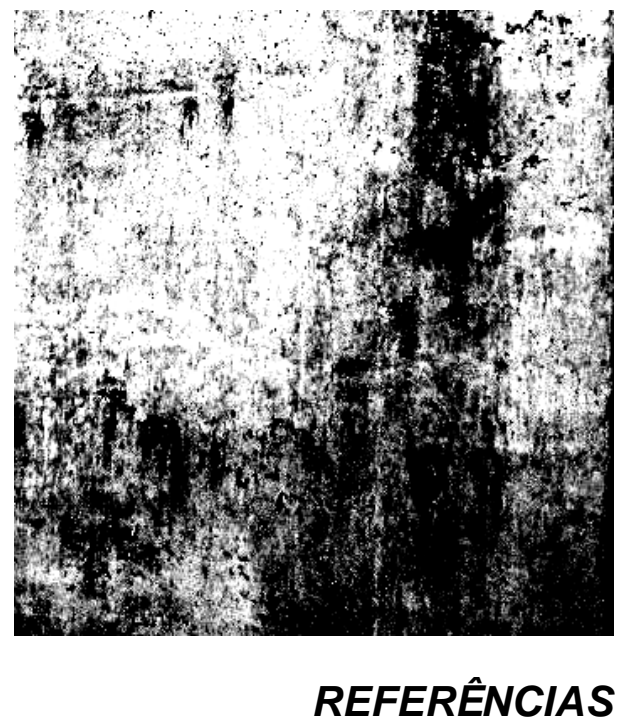




\section{Livros, artigos e teses}

ACAYABA, M. M. Residências em São Paulo 1947-1975. São Paulo: Projeto, 1986.

ADRIÁ, M. Latin America's Constructed Architecture. In: EDITORS of Phaidon Press. 10.10_2: 100 architects, 10 critics. Nova Iorque: Phaidon, 2005. p. 409.

AMARAL, A. A. Internacionalismo e nacionalismo no modernismo brasileiro. In: . A. Artes Plásticas na Semana de 22. São Paulo: Editora 34, 1998. p. 21-50.

ANDRADE, C. R. M. Arquitetura \& Habitação Social em São Paulo 1989-1992. São Carlos: EESC-USP, 1992.

ANDREOLLI, E.; FORTY, A. Projetos recentes: estudos de caso. In: Arquitetura Moderna Brasileira. Londres: Phaidon, 2004. p. 204-222.

ARANTES, O. B. F. O Lugar da Arquitetura depois dos modernos. São Paulo: Edusp, 1993.

. Os Limites do Desenho Urbano. In: SILVA, K. P. (Org.). A Cidade Contemporânea: tendências e conceitos. Bauru: Unesp, 1995. p. 56-71.

. Lúcio Costa e a "Boa Causa" da Arquitetura Moderna. In: ARANTES, O. B. F.; ARANTES, P. E. Sentido da Formação. São Paulo: Paz e Terra, 1997. p. 113-133.

O Urbanismo em fim de linha. São Paulo: Edusp, 1998.

. Uma estratégia fatal. A cultura nas novas gestões urbanas. In: ARANTES, O.; VAINER, A.; MARICATO, E. A cidade do pensamento único: desmanchando conceitos. Petrópolis: Vozes, 2000. p. 11-74.

Cultura e Transformação Urbana. In: PALLAMIN, V. M.; LUDEMANN, M. (Org.). Cidade e Cultura: esfera pública e transformação urbana. São Paulo: Estação Liberdade, 2002. p. 59-70.

ARANTES, P. F. Arquitetura Nova. Sérgio Ferro, Flávio Império e Rodrigo Lefevre. De Artigas aos Mutirões. São Paulo: Editora 34, 2002.

ARTIGAS, R. (Org.). Paulo Mendes da Rocha. São Paulo: Cosac Naify, 2002.

ARTIGAS, V. Le Corbusier e o imperialismo. In: Caminhos da Arquitetura. São Paulo: Cosac Naify, 2004. p. 23-29. (artigo originalmente publicado em: Fundamentos, Revista de Cultura Moderna, São Paulo, ano 3, n. 18, p. 8-9, maio 1951). (a)

A Bienal é contra os artistas brasileiros. In: Caminhos da Arquitetura. São Paulo: Cosac Naify, 2004. p. 30-34. (artigo originalmente publicado em: Fundamentos, Revista de Cultura Moderna, São Paulo, ano 4, n. 23, p. 10-12, dez. 1951). (b)

Os caminhos da arquitetura moderna. In: Caminhos da Arquitetura. São Paulo: Cosac Naify, 2004, p. 35-50. (artigo originalmente publicado em: Fundamentos, Revista de Cultura Moderna, São Paulo, ano 4, n. 24, p. 20-25, jan. 1952). 
Aos Formandos da FAUUSP. In:

Caminhos da Arquitetura. São Paulo:

Cosac Naify, 2004. p. 59-63. (Discurso de Paraninfo na colação de grau dos arquitetos formados pela FAUUSP em 1955. texto originalmente publicado em: AD Arquitetura $e$ Decoração, São Paulo, ano 4, n. 17, maio/jun. 1956).

Revisão Crítica de Niemeyer. In:

Caminhos da Arquitetura. São Paulo: Cosac Naify, 2004. p. 100-101. (artigo originalmente publicado em: Acrópole, São Paulo, ano 20, n. 237, p. 420, jul. 1958).

Aos formandos da FAUUSP. In:

Caminhos da Arquitetura. São Paulo,

Cosac Naify, 2004, p. 70-73. (Discurso de Paraninfo na colação de grau dos arquitetos formados pela FAUUSP em 1958. texto originalmente publicado em: Acrópole, São Paulo, ano 21, n. 244, p. 125, fev. 1959). (a)

Arquitetura e Cultura Nacionais. In: Caminhos da Arquitetura. São Paulo: Cosac Naify, 2004. p. 74-81. (aula inaugural ministrada na Faculdade de Arquitetura e Urbanismo da Universidade Federal do Rio Grande do Sul em 1959. Texto originalmente publicado em: Cadernos de Estudos, Porto Alegre, Centro dos Estudantes Universitários de Arquitetura, n. 6, 1959). (b)

Uma Falsa Crise. In: Caminhos da Arquitetura. São Paulo: Cosac Naify, 2004. p. 102-107. (artigo originalmente publicado em: Acrópole, São Paulo, ano 27, n. 319, p. 21-22, jul. 1965).

Arquitetura e Construção. In: Caminhos da Arquitetura. São Paulo: Cosac Naify, 2004. p. 119-121. (artigo originalmente publicado em: Catálogo da IX Bienal de São Paulo. Acrópole, São Paulo, ano 31, n. 368, dez. 1969).

Arquitetura e Comunicação. In: Caminhos da Arquitetura. São Paulo: Cosac Naify, 2004. p. 132-138. (artigo escrito em 1970, publicado pela primeira vez em: ARTIGAS, V. Caminhos da Arquitetura. São Paulo: Livraria Editora Ciências Humanas, 1981.)

Depoimento. In: XAVIER, A. (Org.). Arquitetura Moderna Brasileira: depoimento de uma geração. São Paulo: Pini, 1987, p. 186-195. (artigo originalmente publicado em: $A$ Construção São Paulo, São Paulo, n. 1910, p. 14-22, set. 1984).

As idéias do velho mestre. In: Caminhos da Arquitetura. São Paulo: Cosac Naify, 2004. p. 167-173. (Entrevista ao jornalista Paulo Markun realizada em 10 de novembro de 1984 e publicada alguns dias após a sua morte em: Folha de São Paulo, São Paulo, 19 jan. 1985).

As posições dos anos 50. In: Caminhos da Arquitetura. São Paulo: Cosac Naify, 2004. p. 151-173. (entrevista de Vilanova Artigas a Aracy Amaral realizada em 1980, originalmente publicada em: Projeto, São Paulo, n. 109, p. 95-102, abr. 1988).

Caminhos da Arquitetura. São Paulo: Pini: Fundação Vilanova Artigas, 1986.

. Vilanova Artigas: arquitetos brasileiros. São Paulo: Instituto Lina Bo e P. M. Bardi: Fundação Vilanova Artigas, 1997.

Caderno dos Riscos originais: projeto do edifício da FAU/USP na Cidade Universitária. São Paulo: FAU-USP, 1998. 
Caminhos da Arquitetura. [Organização José Tavares Correia de Lira, Rosa Artigas].

São Paulo: Cosac Naify, 2004.

BAUDRILLARD, J. Simulacros e Simulação. Lisboa: Relógio d'água, 1991.

BONDUKI, N. Habitar São Paulo: reflexões sobre a gestão urbana. São Paulo: Estação Liberdade, 2000.

BRUAND, Y. Arquitetura Contemporânea no Brasil. São Paulo: Perspectiva, 1981.

BUCCI, A. São Paulo: quatro imagens para quatro operações. Da dissolução dos edifícios e como atravessar paredes. 2005. São Paulo: Tese (Doutorado em Arquitetura) - Faculdade de Arquitetura e Urbanismo, Universidade de São Paulo, São Paulo, 2005.

BUZZAR, M. A. João Batista Vilanova Artigas: elementos para a compreensão de um caminho da arquitetura brasileira. 1996. Dissertação (Mestrado em Arquitetura) - Faculdade de Arquitetura e Urbanismo, Universidade de São Paulo, São Paulo, 1996.

CALADO, C. Tropicália. São Paulo: Ed. 34, 1997.

CALDEIRA, T. P. R. do. Cidade de Muros: crime, segregação e cidadania em São Paulo. São Paulo: Edusp: Editora 34, 2000.

CARAMELlA, E. História da Arte - Fundamentos Semióticos: teoria e método em debate. Bauru: EDUSC, 1998.

CARDOSO, L. A. F.; OLIVEIRA, O. F. de (Org.). (RE) Discutindo o Modernismo. Salvador: Programa de Mestrado em Arquitetura e Urbanismo da UFBA, 1997.

CASTRAL, P. C. Territórios: a construção do espaço nas residências projetadas por Paulo Mendes da Rocha [décadas de 60 e 70]. 1998. Dissertação (Mestrado em Arquitetura) Escola de Engenharia de São Carlos, Universidade de São Paulo, São Carlos, 1998.

CAVALCANTI, L. Quando o Brasil era Moderno: Guia de Arquitetura 1928-1960. Rio de Janeiro: Aeroplano, 2001.

. Moderno e Brasileiro: a história de uma nova linguagem na arquitetura, (1930-60). Rio de Janeiro: Jorge Zahar, 2006.

CAVAlCANTI, L.; LAGO, A. C. Ainda Moderno? Arquitetura Brasileira Contemporânea. Rio de Janeiro: Nova Fronteira, 2005.

CEJKA, J. Tendencias de la Arquitectura Contemporánea. México DF: G. Gili, 1999.

CERVER, F. A. Atlas de Arquitectura Atual. Colonia: Könemann, 2000.

COLQUHOUN, A. Modernidade e Tradição Clássica. São Paulo: Cosac Naify, 2004.

CORRÊA, M. L. Artigas: da idéia ao projeto. 1998. Dissertação (Mestrado em Arquitetura) Faculdade de Arquitetura e Urbanismo, Universidade de São Paulo, São Paulo, 1998. (a) 
CORRÊA, M. L. Homenzinhos que se olham. In: ARTIGAS, V. Caderno dos Riscos originais: projeto do edifício da FAU/USP na Cidade Universitária. São Paulo: FAU- USP, 1998, p. 19-28. (b)

COSTA, L. Lúcio Costa: registro de uma vivência. São Paulo: Empresa das Artes, 1995.

EDITORS of Phaidon Press. SPBR. In: 10.10_2: 100 architects, 10 critics. Nova Iorque: Phaidon, 2005, p. 356-359.

DEBORD, G. A Sociedade do Espetáculo. Rio de Janeiro: Contraponto, 1997.

DROSTE, M. Bauhaus. Colonia: Taschen, 1994.

FEATHERSTONE, M. Cultura do Consumo e Pós-Modernismo. São Paulo: Studio Nobel, 1995.

O Desmanche da Cultura: globalização, pós-modernismo e identidade. São Paulo: Studio Nobel, 1997.

FELDMAN, S. Planejamento e Zoneamento, São Paulo 1947-1972. 1996. Tese (Doutorado em Arquitetura) - Faculdade de Arquitetura e Urbanismo, Universidade de São Paulo, São Paulo, 1996.

FERNANDES, F. A Revolução burguesa no Brasil. Rio de Janeiro: Zahar, 1975.

FERRARA, L. D. Os Significados Urbanos. São Paulo: Edusp, 2000.

FERRAZ, M. C. (Ed.). Lina Bo Bardi. São Paulo: Empresa das Artes, 1993.

FERREIRA, A. F. de; CORRÊA, M. E. P.; MELLO, M. G. de (Org.). Arquitetura Escolar Paulista. São Paulo: FDE: Imprensa Oficial do Estado, 1998.

FERREIRA, A. F. de; MELLO, M. G. (Org.). Arquitetura Escolar Paulista: estruturas préfabricadas. São Paulo: FDE, 2006.

FERRO, S. O Canteiro e o Desenho. São Paulo: Prolivros, 2005. Arquitetura e Trabalho Livre. São Paulo: Cosac Naify, 2006.

FIALHO, V. C. S. Arquitetura, texto e imagem: a retórica da representação nos concursos de arquitetura. 2007. Tese (Doutorado em Arquitetura) - Faculdade de Arquitetura e Urbanismo, Universidade de São Paulo, São Paulo, 2007. Cap. 6. O concurso para o Pavilhão de Sevilha 92: Transição. p. 167-227.

FICHER, S.; ACAYABA, M. M. Arquitetura Moderna Brasileira. São Paulo: Projeto Editores Associados, 1982.

FIORIN, E. São Paulo - as marginais do Rio Pinheiros e os megaprojetos arquitetônicos do capital financeiro: tempos de globalização. 2003. Dissertação (Mestrado em Arquitetura) Escola de Engenharia de São Carlos, Universidade de São Paulo, São Carlos, 2003.

FRAMPTON, K. História Crítica da Arquitetura Moderna. São Paulo: Martins Fontes, 1997. 
FRÚGOLI, H. Jr. São Paulo: Espaços Públicos e Interação Social. São Paulo: Marco Zero: SESC, 1995.

Centralidade em São Paulo: tragetórias, conflitos e negociações na metrópole. São

Paulo: Cortez: Edusp, 2000.

GHIRARDO, D. Arquitetura Contemporânea. São Paulo: Martins Fontes, 2002.

GOODWIN, P. L. Brazil Builds: architecture new and old 1652-1942. Nova Iorque: MOMA, 1943.

HARVEY, D. A Condição Pós-Moderna. São Paulo: Loyola, 1996.

HELENA, L. Modernismo Brasileiro e Vanguarda. São Paulo: Ática, 1986.

HERTZBERGER, H. Lições de Arquitetura. São Paulo: Martins Fontes, 1999.

IBELINGS, H. Supermodernismo: la arquitectura en la era de la globalización. Barcelona: G. Gili, 1998.

JACOBS, J. Morte e vida das grandes cidades. São Paulo: Martins Fontes, 1961.

JAMESON, F. Pós-Modernismo: A lógica Cultural do Capitalismo Tardio. São Paulo: Ática, 1997.

A Cultura do Dinheiro. Petrópolis: Vozes, 2001.

JENCKS, C. El Linguaje de la Arquitectura Pós-Moderna. Barcelona: G. Gili, 1984.

. Movimentos Modernos em Arquitetura. Lisboa: Edições 70, 1985.

JOHNSON, P.; WIGLEY, M. Arquitectura Deconstrutivista. Barcelona: G. Gili, 1988.

JUNQUEIRA BASTOS, M. A. Pós-Brasília: Rumos da Arquitetura Brasileira. São Paulo: Perspectiva, 2003.

KAMITA, J. M. Vilanova Artigas. São Paulo: Cosac Naify, 2000.

KOOLHAAS, R.; MAU, B. $S, M, L, X L$. Nova Iorque: The Monacelli Press, 1995.

KOOP, A. Quando o moderno não era um estilo e sim uma causa. São Paulo: Studio Nobel: Edusp, 1990.

KOURY, Ana Paula. Grupo Arquitetura Nova: Flávio Império, Rodrigo Lefevre e Sérgio Ferro. São Paulo: Romano Guerra: Edusp: Fapesp, 2003.

LE CORBUSIER. Precisões sobre um estado presente da arquitetura e do urbanismo. São Paulo: Cosac Naify, 2004.

LIMA, Z. R. M. de A. A Produção da Paisagem Urbana no Universo Pós-funcionalista. In: SILVA, K. P. (Org.). A Cidade Contemporânea: tendências e conceitos. Bauru: Unesp, 1995. p. 47-55. 
A cidade como espetáculo: $\mathrm{O}$ arquiteto no paradoxo da estetização da cultura contemporânea. 2000. Tese (Doutorado em Arquitetura) - Faculdade de Arquitetura e Urbanismo, Universidade de São Paulo, São Paulo, 2000.

LIPOVETSKY, G. O Império do Efêmero: a moda e seu destino nas sociedades modernas. São Paulo: Companhia das Letras, 1989.

MARTINS, C. A. F. Arquitetura e estado no Brasil: elementos para uma investigação sobre a constituição do discurso moderno no Brasil: a obra de Lucio Costa 1924-1952. 1987. Dissertação (Mestrado em Arquitetura) - Faculdade de Filosofia, Letras, Ciências Humanas e História, Universidade de São Paulo, São Paulo, 1987.

Construir uma Arquitetura, construir um País. In: SHWARTZ, J. (Org.). Da Antropofagia a Brasília: Brasil 1920-1950. São Paulo: FAAP: Cosac Naify, 2002. p. 373-383.

MELO, C. H. de. O design gráfico brasileiro: anos 60. São Paulo: Cosac Naify, 2006.

MEYER, R. M. P. Metrópole e Urbanismo anos 50. 1991. Tese (Doutorado em Arquitetura) Faculdade de Arquitetura e Urbanismo, Universidade de São Paulo, São Paulo, 1991.

MILHEIRO, A. V.; NOBRE, A. L.; WISNIK, G. Coletivo: arquitetura paulista contemporânea. São Paulo: Cosac Naify, 2006.

MINDLIN, Henrique E. Arquitetura moderna no Brasil. Rio de Janeiro: Aeroplano, 1999.

MONTANER, J. M.; VILLAC, M. I. Mendes da Rocha. Barcelona: G. Gili, 1996.

MONTANER, J. M. Arquitectura y Crítica. Barcelona: G. Gili, 1999.

G. Gili, 2001.

A Modernidade Superada: arquitetura, arte e pensamento do século XX. Barcelona:

MUSEU Brasileiro da Escultura Marilisa Rathsam. São Paulo: Editora JC, 2001.

NESBITT, K. (Org.). Uma nova Agenda para a Arquitetura. São Paulo: Cosac Naify, 2006.

NIEMEYER, O. Depoimento. In: XAVIER, A. (Org.). Arquitetura Moderna Brasileira: depoimento de uma geração. São Paulo, Pini, 1987. p. 221-224. (texto originalmente publicado em: Módulo, Rio de Janeiro, n. 9, p. 3-6, fev. 1958).

OLIVEIRA, F. Crítica à razão dualista - O ornitorrinco. São Paulo: Boitempo, 2003.

OLIVEIRA, O. Lina Bo Bardi. Sutis Substâncias da Arquitetura. São Paulo: RG: G. Gili, 2006.

PALlAMIN, V. M.; LUDEMANN, M. (Org.). Cidade e Cultura. São Paulo: Estação Liberdade, 2002.

PEIXOTO, N. B. Arte/ Cidade - A Cidade e suas Histórias. São Paulo: SESC, 1997.

PIÑÓN, H. Paulo Mendes da Rocha. São Paulo: Romano Guerra, 2002.

PORTOGHESI, P. Depois da Arquitetura Moderna. São Paulo: Martins Fontes, 2002. 
PUNTONI, A. Die FAU des Artigas und wir alle. / A FAU de Artigas e todos nós. In: LICATA, G.; BOHLAND, F. Brasil das Reisen und die Architektur / Viajar e Arquitetura. Kassel: Universität Kassel, 2003. p. 28-31.

QUEIROZ, M. V. de. Arquitetura e Desenvolvimento. In: XAVIER, A. (Org.). Arquitetura Moderna Brasileira: depoimento de uma geração. São Paulo: Pini, 1987. p. 155-172. (artigo originalmente publicado em: Revista do Instituto de Ciências Sociais, Rio de Janeiro, n. 01, p. 171-198, 1962).

RECAMÁN, L. Os Impasses da Arquitetura Paulista Recente. In: DO_CO, MO.MO BRASIL, 3, 1999, São Paulo. Anais do $3^{\circ}$. Seminário Do_co, mo.mo: a permanência do moderno. São Paulo, 1999.

. Forma sem utopia. In: ANDREOLLI, E.; FORTY, A. (Org.). Arquitetura Moderna Brasileira. Londres: Phaidon, 2004. p. 108-139.

RILEY, T. Light Construction - Transparencia e Ligeireza en la Arquitectura de los 90. Barcelona: G. Gili, 1996.

RIZEK, C. S. A Crise Contemporânea. In: SILVA, K. P. (Org.). A Cidade Contemporânea: tendências e conceitos. Bauru: Unesp, 1995. p. 72-89.

ROCHA, P. M. Cultura e Natureza. In: PIÑÓN, H. Paulo Mendes da Rocha. São Paulo: Romano Guerra, 2002. p. 15-41.

SANTOS, M. A Urbanização Brasileira. São Paulo: Hucitec, 1994.

SANTOS, V. C. Concursos de Arquitetura em São Paulo. 202. Dissertação. (Mestrado em Arquitetura) - Faculdade de Arquitetura e Urbanismo, Universidade de São Paulo, São Paulo, 2002. Capitulo 04: Os pavilhões nacionais. p. 145-163.

SCHWARZ, R. Cultura e Política, 1964-1969. In: Cultura e Política. São Paulo: Paz e Terra, 2001. p. 07-58. (texto originalmente publicado em francês, em 1970).

As idéias fora do lugar. In: . Cultura e Política. São Paulo: Paz e Terra, 2001. p. 59-83. (texto originalmente publicado em francês, em 1972).

Nacional por Subtração. In: Cultura e Política. São Paulo: Paz e Terra, 2001. p. 108-135. (texto originalmente publicado em: Folha de São Paulo, 07 jun. 1986).

Posfácio. In: ARANTES, P. F. Arquitetura Nova: Sérgio Ferro, Flávio Império e Rodrigo Lefèvre, de Artigas aos mutirões. São Paulo: Editora 34, 2002. p. 225-232.

SEGAWA, H. Arquiteturas no Brasil. 1900-1990. São Paulo: Edusp, 1998.

Rompecabezas latinoamericano. In: $2^{\circ}$. PREMIO Mies van der Rohe de Arquietctura Latinoamericana. Barcelona: Fundación Mies van der Rohe: Actar, 2000. p. 14-17.

SEGRE, R. Arquitetura Contemporânea Brasileira. Petrópolis: Viana e Mosley, 2003. Jovens Arquitetos - Brasil. Rio de Janeiro: Viana \& Mosley, 2004. 
SERAPIÃO, F. São Paulo - Guia de Arquitetura Contemporânea. Rio de Janeiro: Viana \& Mosley, 2005.

SOARES, A. A. Estudo de Caso e Levantamento de Campo da Residência Família Bueno Netto de Paulo Mendes da Rocha - Catanduva-SP. Monografia - Curso de Arquitetura e Urbanismo, Universidade Paulista, São José do Rio Preto-SP, 2007. mimeo.

SOMEKH, N. A (des) verticalização de São Paulo. 1987. Dissertação. (Mestrado em Arquitetura) - Faculdade de Arquitetura e Urbanismo, Universidade de São Paulo, São Paulo, 1987.

SPADONI, F. A Transição do Moderno. 2003. Tese. (Doutorado em Arquitetura) - Faculdade de Arquitetura e Urbanismo, Universidade de São Paulo, São Paulo, São Paulo, 2003.

STEELE, J. Architecture Today. Londres: Phaidon, 1997.

UNDERWOOD, D. K. Oscar Niemeyer: e o modernismo de formas livres no Brasil. São Paulo: Cosac Naify, 2002.

VENTURI, R. Complejidad y Contradicción en la Arquitectura. Barcelona: G. Gili, 1972.

VENTURI, R; BROWN, S.; IZENOUR, S. Aprendendo com Las Vegas. São Paulo: Cosac Naify, 2003.

VILARIÑO, M. C. do. Habitação verticalizada na cidade de São Paulo dos anos 30 anos 80. Investigação acerca da contribuição dos arquitetos modernos ao tema. Estudo de casos. Dissertação. (Mestrado em Arquitetura) - Faculdade de Arquitetura e Urbanismo, Universidade de São Paulo, São Paulo, 2000.

WISNIK, G. Lúcio Costa. São Paulo: Cosac Naify, 2001.

XAVIER, A. (Org.). Arquitetura Moderna Brasileira: depoimentos de uma geração. São Paulo: Pini: ABEA: Fundação Vilanova Artigas, 1987.

XAVIER, A. F. M.; LEMOS, C. A.; CORONA, E. Arquitetura Moderna Paulistana. São Paulo: Pini, 1983.

ZEIN, R. V. Arquitetura brasileira, Escola Paulista e as casas de Paulo Mendes da Rocha. Dissertação. (Mestrado em Arquitetura) - Faculdade de Arquitetura e Urbanismo, Universidade Federal do Rio Grande do Sul, Porto Alegre, 2000.

O Lugar da Crítica. Ensaios oportunos de Arquitetura. São Paulo, Porto Alegre: ProEditores: Ritter dos Reis, 2002.

Artigos de periódicos

AB’SÁBER, T. A. M. Um Debate. Arquitetura e História, Arte e Política. Caramelo, São Paulo, n. 02, p. 14-17, jul. 1991. 
ACAYABA, M. M. Vilanova Artigas, amado mestre. Tendências atuais da arquitetura brasileira: Vilanova Artigas 1915/1985, São Paulo, ed. esp., p. 48-52, 1985.

ALCÂNTARA, D. Dossiê: O que andam fazendo as novas gerações de arquitetos? Módulo, Rio de Janeiro, n. 71, p. 41-61, 1982.

ANELLI, R. A. Urbanidade do Subsolo. Novos Estudos CEBRAP, São Paulo, n. 68, p. 171176, mar. 2004.

ARQ./A. Lisboa: Futurmagazine, n. 26, jul./ago. 2004.

ARQUITETURA Paulista é destaque internacional. Boletim IAB, n. 45, p. 04, jun./jul. 2004.

ARTIGAS, R. C.; SILVA, D. T. Escola Paulista - sobre brutalismo, mitos e bares - ou de como consagrar uma impropriedade. $A U$, São Paulo, n. 17, p. 61-63, abr./maio 1988.

ARTIGAS, V. As posições dos anos 50. [Entrevista concedida a Aracy Amaral realizada em 1980]. Projeto, São Paulo, n. 109, p. 95-102, abr. 1988.

Contribuição para o relatório sobre o ensino de arquitetura UIA - UNESCO - 1974. Caramelo, São Paulo, n. 06, p. 31-38, 1993. (artigo publicado originalmente em: Sobre a História do Ensino de Arquitetura e Urbanismo no Brasil, ABEA, 1977).

ASQUINO, M. S. Quem somos nós. Caramelo, São Paulo, n. 02, p. 12-13, jun. 1991.

AZEVEDO, R. M. de. Futuro Passado. AU, São Paulo, n. 35, p. 76-79, abr./maio 1991.

BARACUHY, J. L. Ideais Amadurecidos. Arquitetura \& Construção, São Paulo, n. 09, p. 30, set. 2004.

BARELLI, S. A polêmica de Sevilha e os premiados no concurso do pavilhão do Brasil. Projeto. São Paulo, n. 139, p. 62-77, mar. 1991.

BARTALINI, V. Espaços Livres Públicos na Cidade. Óculum, Campinas, n. 04, p. 64-67, nov. 1993.

BASTIAN, W. Arquitetura Coletiva. Arc Design, São Paulo, n. 50, p. 38-42, out. 2000.

BAUDRILLARD, J. A violência do Objeto. AU, São Paulo, n. 64, p. 69-71, fev./mar. 1996. 1999.

. Verdade ou Radicalidade na Arquitetura. AU, São Paulo, n. 84, p. 49-50, jun./jul.

BISELLI, M. Impressões sobre arquitetura dos anos 90. AU, São Paulo, n. 96, p. 84-89, jun./jul. 2001.

Amadurecimeto da nova geração. [Entrevista concedida a AU]. AU, São Paulo, n. 113, p. 34-35, ago. 2003.

Um fã da arquitetura brasileira. [Entrevista concedida a Valentina Figuerola]. $A U$, São Paulo, n. 138, p. 56-59, set. 2005. 
BOZZO, C. Gian Carlo Gasperini. Metáfora em Diagonal. AU, São Paulo, n. 24, p. 74-82, jun./jul. 1989.

Assembléia DF. Sutil Resgate de uma Modernidade. AU, São Paulo, n. 28, p. 32-37, fev./mar. 1990.

BRAGA, M. Nos anos 80 o interesse renovado pelo projeto e o domínio da prática. Projeto, São Paulo, n. 228, p. 97, jan./fev. 1999.

Arquitetos têm direito de criticar o trabalho de colegas? Há uma forma ética de fazer isso? [Depoimento]. AU, São Paulo, 137, p. 21, ago. 2005.

BRANDÃO, L. Rudeza Minimalista. (Agência DPTO). Design Interiores, São Paulo, n. 46, p. 79-82, jun. 1995.

BRASILE: Nuova Architettura. Casabella, Milão, n. 723, p. 30-59, jun. 2004.

BUCCI, A. Um Arquiteto em busca de Razões. [Entrevista concedida a Valentina Figuerola]. Projeto, São Paulo, n. 137, p. 82-84, ago. 2005.

BUCCI, A.; PUNTONI, A. Escola Ataliba Leonel. $M D C$, Belo Horizonte, ano 01, n. 02, p. 50-51, fev. 2006.

BUCCI, A.; PUNTONI, A.; RAZUK, A. Arquitetura Paulista. Projeto, São Paulo, n. 143, p. 68, jul. 1991.

BUCCI, A; PUNTONI, A.; VILELA, J. O. Pavilhão do Brasil na Expo 92 Sevilha. Projeto, São Paulo, n. 138, p. 40, fev. 1991.

BUCCI, A; PUNTONI, A.; VILELA, J. O.; DENTE, E.; PUNTONI, P. A Polêmica de Sevilha e os premiados no concurso do pavilhão do Brasil. [Entrevista concedida a Suzana Barelli]. Projeto, São Paulo, n. 139, p. 62-63, mar. 1991.

CAFCALAS, A. O ultramoderno e a des/ilusão formal. Projeto, São Paulo, n. 263, p. 30-31, jan. 2002.

CALDEIRA, V.; RIBEIRO, A. C. Residência em São Paulo, SP: MMBB arquitetos. $A U$, São Paulo, n. 82, p. 55-7, fev./mar. 1999.

CASTRO, M. B. de. Paulista Architecture: From Generation to Generation. $A+U$, Tókio, n. 341, p. 04-08, fev. 1999.

COMAS, C. E. D. Paulo Mendes da Rocha: o prumo dos 90. AU, São Paulo, n. 97, p. 102109, ago./set. 2001.

CORBIOLI, N. Recuperados, armazéns transformam-se em centro de informação e cultura. (Conjunto KKKK, M. Ferraz e F. Fanucci). Projeto, São Paulo, n. 265, p. 40-46, mar. 2002.

Entorno e memória fabril da região são incorporados como elementos de projeto. (Terminal de ônibus urbanos da Lapa, Núcleo de Arquitetura). Projeto, São Paulo, n. 289, p. 48-54, mar. 2004. 
CZARNECKI, J. E. Dental Clinic, Orla ndia, Brazil. Architectural Record, s/n, p. 140-143, jul. 2002.

DAL CO, F. Paulo Mendes da Rocha, un maestro de ascoltare e osservare. Casabella, Milão, n. 758, p. 57-59, set. 2007.

DE VOLTA ao moderno. Cimento Hoje. Informativo ABCP, São Paulo, n. 42, p. 06-07, out. 2002.

DEGELO, M. Uma casa embaixo d'água. (Casa Mariante, MMBB). Casa e Jardim, São Paulo, n. 592, p. 80-87, maio 2004.

Divã ousado. (Clínica de Psicanálise de Orlândia, MMBB). Casa e Jardim, São Paulo, ano 51, n. 601, p. 80-4, fev. 2005.

ENTENDA o vaivém do julgamento. [Ata de Encerramento dos Trabalhos do Júri]. Projeto, São Paulo, n. 138, p. 39, fev. 1991.

ESCORIAL, L. E. (Ed.). Clínica de Odontologia spbr arquitetos. ARQ./A, Lisboa, n. 26, p. $37-$ 41, jul./ago. 2004.

ETCHBEHERE, J. O grito afônico das velhas e ultrapassadas lições. [Opinião do leitor: Repercussões do Concurso de Sevilha]. Projeto, São Paulo, (140): 10-15, abr. 1991.

FELICIANI, M. R. Vitrine da Arte na Avenida Paulista: Centro Cultural FIESP. Finestra Brasil, São Paulo, n. 15, p. 98-101, out./dez. 1998.

FERNÁNDEZ-GALIANO, L. Los héroes amargos. Houellebecq y Koolhaas, La toxidad lúcida del pesimismo. Arquitectura Viva, Madrid, n. 74, p. 17-31, set./out. 2000.

Arquitectos en La passarela. El espectáculo y la escala. AV Monografias. Madrid, n. 104, p. 94-5, nov./dez. 2003. (a)

. Obras que se exhiben. AV Monografias. Madrid, n. 104, p. 96-7, nov./dez. 2003. (b)

. Arquitectos de papel. AV Monografias. Madrid, n. 104, p. 98-9, nov./dez. 2003. (c)

. El autor y la audiencia. AV Monografias. Madrid, n. 104, p. 100-1, nov./dez. 2003.

(d)

Estilo frente a escala. AV Monografias. Madrid, n. 104, p. 102-3, nov./dez. 2003. (e)

(Ed.) SPBR. Biblioteca de la Universidad Católica, Rio de Janeiro. AV Proyetos, Madrid, n. 015, p. 10-11, maio/jun. 2006.

FERRARA, L. D. Redesenho de uma idéia. Cadernos de Arquitetura, Bauru, n. 01, p. 05-12, jan./jun. 1996.

FERRO, S. Residência no Butantã. Acrópole, São Paulo, n. 319, p. 34-35, jul. 1965.

Arquitetura Nova. Arte em Revista, São Paulo, n. 04 p. 89-94, ago. 1980. (texto divulgado em 1966 e originalmente publicado em: Teoria e Prática, n. 1, São Paulo, 1968) 
1980.

Reflexões para uma política na Arquitetura. Arte em Revista, n. 04, p. 95-99, ago.

A geração ruptura. $A U$, São Paulo, n. 03, p. 56-57, nov. 1985.

Reflexões sobre o brutalismo caboclo. [Entrevista concedida a Marlene Milan Acayaba]. Projeto, São Paulo, n. 86, p. 68-70, abr. 1986.

FICHER, S. Anotações sobre o pós-modernismo. Projeto, n. 74, p. 34-42, abr. 1985.

FINA, H. et. al. Concurso Público de anteprojetos para a matriz de Cerqueira César. Projeto, São Paulo, n. 128, p. 72-73, dez. 1989.

FINA, H.; SOARES, L. M.; URSINI, M.; GOMES, S. B.; SOUZA, S. L. S. Réplica a Edson Mahfuz e Sérgio Teperman. [Opinião do Leitor]. Projeto, São Paulo, n. 134, p. 10-11, nov./ dez. 1990.

Núcleo de Arquitetura. Projeto, São Paulo, n. 143, p. 72, jul. 1991.

FOSTER, H. Voces en vanguardia. Pequeño diccionario de ideas del diseño actual. Arquitectura Viva, Madrid, n. 93, p. 23-31, nov./dez. 2003.

FRANCISCO, E. R.; FRANÇA, L. M. L. Arquitetos Paulistas Associados S. C. Projeto, São Paulo, n. 143, p. 70, jul. 1991.

FUTUGAWA, Y. (Ed.). SPBR arquitetos. House in Carapicuíba, São Paulo, Brazil. G.A. Houses, Tóquio, n. 80, p. 24-5, nov. 2004.

GAMA, M. Leyendo (sobre) el paisage de Rio. Arquine, México DF, n. 37, p. 13, out. 2006.

GARAGEM Trianon. AU, São Paulo, n. 88, p. 78-79, fev./mar. 2000.

Projeto, São Paulo, n. 239, p. 51. jan. 2001.

GAUDENZI, L. M. Alguém foi desrespeitado? [Opinião do leitor: Repercussões do Concurso de Sevilha]. Projeto, São Paulo, n. 140, p. 10-15, abr. 1991.

GIMENES, L. E. Autenticidade e Rudimento - Paulo Mendes da Rocha e equipes em recentes intervenções. $A U$, São Paulo, n. 79, p. 70-71, ago./set. 1998.

GONÇALVES, F. M. Modernismo Hoje? Caramelo, São Paulo, n. 02, p. 80-81, jun. 1991. 1992. Faculdade de Medicina de Botucatu-SP. AU, São Paulo, n. 41, p. 18-19, abr./maio,

Discussão sobre o papel dos espaços livres públicos nos bairros de elite contemporâneos. Revista Paisagem e Ambiente, São Paulo, n. 15, p. 09-33, dez. 2002.

GONÇALVES, F. M.; FREIRE, L. M.; VILARIÑO, M. C. do; LIMA, Z. R. M. A. de. Projeto Paulista de Arquitetura S.C. Ltda. Projeto, São Paulo, n. 143, p. 71, jul. 1991.

GORGATTI, V.; FRANCO, F. M.; MOREIRA, M.; BRAGA, M. Memorial do Pavilhão da Expo' 92 em Sevilha. Projeto, São Paulo, n. 139, p. 68-69, mar. 1991. (a) 
. Via Arquitetura. Projeto, São Paulo, n. 143, p. 73, jul. 1991. (b)

GUATARRI, F. A Restauração da Paisagem Urbana. Revista do Patrimônio Histórico e Artístico Nacional, Rio de Janeiro, n. 24, p. 293-300, maio 1996.

GUEDES, J. Por uma nova Arquitetura. AU, n. 98, p. 76-77, out./nov. 2001.

GUERRA, A. Quattro Progetti del gruppo MMBB. Casabella, Milão, n. 723, p. 31-47, jun., 2004.

Projeto para todos. Bravo, São Paulo, n. 110, p. 43, out. 2006.

JAMESON, F. O pós-modernismo e a sociedade de consumo. Novos Estudos Cebrap, n. 12, p. 25-45, jun. 1985.

JENCKS, C. Critical Modernism. Architectural Design, n. 70, p. 94-99, 2001.

JORGE, L. A. Crônica de un aprendizaje. Elarqa-Architectura y Diseño, Montevideo, n, 39, p. 06-15, set. 2001.

Dez anos de Solidão. Projeto, São Paulo, n. 263, p. 28-29, jun. 2002.

KATINSKY, J. Uma Perigosa Montagem Ideológica. AU, São Paulo, n. 17, p. 66-71, 1988.

KAY, J. H. A Brief History of Parking: the life and after-life of paving the planet. Architecture Magazine, n. 02, p. 76-79, 122, fev. 2001.

KIEFER, F. O que há contigo arquitetura brasileira? [Opinião do leitor: Repercussões do Concurso de Sevilha]. Projeto, São Paulo, n. 140, p. 10-15, abr. 1991.

KIPNIS, J. El Último Koolhaas. El Croquis, Madrid, n. 79, p. 26-36, 1996.

KOOP, A. Modernismo hoje. Caramelo, São Paulo, v. 1, p. 15-20, 1991.

LARA, F. L. Arquitetura Brasileira volta às páginas das publicações internacionais na década de 90. Projeto, São Paulo, n. 251, p. 08-09, jan. 2001.

LIPOVETSKY, G. Hay que queimar los media? Quaderns, n. 237, p. 14-19, abr. 2003.

MACIEL, C. A. Orquestra filarmônica afro-brasileira. $M D C$, Belo Horizonte, ano 01, n. 01, p. 37-9, jan. 2006. (a)

. Escola Ataliba Leonel. $M D C$, Belo Horizonte, ano 01, n. 02, p. 50-1, fev. 2006. (b) $\overline{\text { 2006. (c) }}$

Terminal de Ônibus Urbanos da Lapa. MDC, Belo Horizonte, ano 01, n. 03, mar.

MAHFUZ, E. C. da. Quem tem medo do pós-modernismo? Notas sobre a base teórica da arquitetura contemporânea. Projeto, São Paulo, n. 101, p. 132-138, jul. 1987.

Em debate, a crise dos anos 80 e tendências da nova década. Projeto, São Paulo, n. 129, p. 146-147, jan./fev. 1990. 
La Arquitectura Consumida en la Hoguera de las Vanidades. Summa +, Buenos Aires, n. 51, p. 86-89, out./nov. 2001.

Arquiteturas Silenciosas. AU, São Paulo, n. 137, p. 38-45, ago. 2005.

MAIA, E.; PODESTÁ, S. E. Até hoje a gente se pergunta que país é este? [Opinião do leitor: Repercussões do Concurso de Sevilha]. Projeto, São Paulo, n. 140, p. 10-15, abr. 1991.

MAISON Mariante. D’ Architectures, Paris, n. 146, p. 62-63, maio 2005.

MARICATO, E.; BONDUKI, N.; SANT'ANNA, C. A. Jr. Habitação, uma utopia possível. Projeto, São Paulo, n. 134, p. 69-90, out./nov. 1990.

MARTINS, C. A. F. Identidade Nacional e Estado no Projeto Modernista: modernidade, Estado e tradição. Óculum, Campinas, São Paulo, n. 02, p. 71-6, 1992.

MAZZA, M. Vertiginosa ascensão ao anonimato ou lânguida preguiça. [Opinião do leitor: Repercussões do Concurso de Sevilha]. Projeto, São Paulo, n. 140, p. 10-15, abr. 1991.

Biblioteca encaixada no contexto. Álvaro Puntoni, Álvaro Razuk e Ângelo Bucci. [Coluna Ser Hurbano]. AU, São Paulo, ano 09, n. 47, p. 24, abr./maio 1993.

MEDEIROS, H. Em torno do Concurso. AU, São Paulo, n. 35, p. 74-75, abr./maio 1991.

MELENDEZ, A. Na década que separa Sevilha de Orlândia, mudaram os arquitetos ou mudou a crítica? Projeto, São Paulo, n. 251, p. 132, jan. 2001.

MÓDULO. Rio de Janeiro: Avenir. Ed. Esp. Vilanova Artigas, 1982.

MONTANER, J. M. Minimalismo: o essencial como norma. Projeto, São Paulo, n. 175, p. 36-44, jun. 1994.

MOOL, C. Dünne schale MIT bewegter Geschichte: Niemeyer-Pavillon renoviert. Baumeister, Munique, s/n, p.12, dez. 2002.

MOTTA, F. Arquitetura Brasileira para a EXPO'70. Acrópole, São Paulo, n. 372, p. 25-31, maio 1970.

MUNGIOLI, A. (Ed.). Evitando soluções convencionais, terminal paulista se destaca pela desconcertante leveza da cobertura. (Terminal do Parque D. Pedro II). Projeto, São Paulo, n. 207, p. 40-45, abr. 1997. (a)

(Ed.). Planos desencontrados, anteparos verticais, varandas, muxarabis, venezianas e beirais controlam a luz e o ar. (Pousada em Juquehy). Projeto, São Paulo, n. 207, p. 46-50, abr. 1997. (b)

(Ed.). Passarela central vazada conecta lâminas paralelas em residencial para estudantes. Projeto, São Paulo, n. 226, p. 63, nov. 1998.

(Ed.). Cotas de ocupação, percurso de acesso e controle da luz marcam relação entre espaço público e privado. (Clínica de Psicanálise). Projeto, São Paulo, n. 237, p. 66-71, nov. 1999. 
(Ed.). Sistemas industrializados: alternativas para pequenas edificações. (Casa em Perdizes, MMBB). Projeto, São Paulo, n. 241, p. 110-3, mar. 2000.

(Ed.). Nova sede acentuará caráter público do CREA cearense, em terreno já ocupado pela entidade. Projeto, São Paulo, n. 260, p. 68-9, out. 2001.

(Ed.). Equipe Mineira é vencedora do Prêmio Usiminas para a nova sede do grupo Corpo. Projeto, São Paulo, n. 267, p. 66-68, maio 2002. (a)

(Ed.). Grande praça homenageará a República com áreas de lazer, culturais e educacionais. (Concurso de projeto para o Memorial À República, SPBR). Design, São Paulo, n. 273, p. 66-67, nov. 2002. (b)

(Ed.). Grande Edificação integra conjunto esportivo e abriga novas instalações. (Concurso Ginásio do Ibirapuera, Núcleo de Arquitetura). Projeto, São Paulo, n. 281, p. 6465 , jul. 2003.

. (Ed.). Fábricas culturais para conter violência na periferia paulistana. Projeto, São Paulo, n. 303, p. 36-7, maio 2005. (a)

. (Ed.). Mineiro-paulista vence concurso para sede da Petrobrás capixaba. Projeto, São Paulo, n. 307, p. 36-8, set. 2005. (b)

NOVA arquitetura brasileira. Projeto, n. 263, p. 34-97, jan. 2002.

NOVA unidade do SESC contribuirá para a recuperação da região central de São Paulo. (Paulo M. Rocha e MMBB). Projeto, São Paulo, n. 275, p. 83, jan. 2003.

OLIVEIRA, N. C. A propósito da frustração nos concursos públicos. Projeto, São Paulo, n. 139, p. 08, mar. 1991.

ORLANDI, A. P. Transparente sotaque modernista. (Casa Mello MMBB). Casas de Autor. Arquitetura \& Construção, São Paulo, n. 01, p. 13-19, [s.d.], ed. esp.

PADOVANO, B. R. Arquitetura Contemporânea no Brasil: o que aconteceu depois de Brasília? Revista de Cultura Brasileña, Madrid, n. 02, p. 14-99, set. 1998.

PAVILHÃO do Brasil. Abrindo o jogo. AU, São Paulo, n. 35, p. 62-73, abr./maio 1991.

PAZZANESE, C. Trajetória de Artigas na Arquitetura Brasileira. [Depoimento a Ivana F. Peters]. Caramelo. São Paulo, ano 0, n. 01, p. 36-45, dez. 1990.

nov./dez. 2003.

Arquitetura Hoje: uma nova geração. Arc Design, São Paulo, n. 33, p. 56-63, Arquitetura Hoje II: urbis et orbis. Arc Design, São Paulo, n. 34, p. 30-7, jan./fev. 2004.

PEREIRA, M. Sevilha, um sonho inacabado para a arquitetura brasileira. Projeto. São Paulo, n. 139, p. 62, mar. 1991. 
PERRONE, R. Um compromisso com a cidade, a sociedade e a cultura. Projeto, São Paulo, n. 263, p. 26-27, jan. 2002.

PIRONDI, C.; TONETTI, A. C. The "New" School of Architecture of São Paulo. $A+U$, Tókio, n. 341, p. 130-133, fev. 1999.

PONTES, A. P. G.; VALENTIN, F. R.; BARBARA, F.; VIÉGAS, F. F. WISNIK, G.; LIMA, M. V. B. Fórum: o percurso do ensino na FAU. Caramelo, São Paulo, n. 06, p. 09-22, 1993.

PROPOSTAS diferenciadas têm como ponto de partida peças e vãos padronizados. Projeto, São Paulo, n. 284, p. 34-5, out. 2003.

PUNTONI, A. Um comentário ao livro de Anatole Koop Quando o moderno não era um estilo, mas uma causa. Caramelo, São Paulo, v. 1, p. 14, 1991.

Estruturas habitacionais urbanas. A cidade como ponto de partida. A idéia do projeto. Urbs. São Paulo, n. 18, p. 38-41, set./out. 2000.

Pensando em Escolas. MDC, Belo Horizonte, ano 01, n. 02, p. 12-15, fev. 2006.

PUNTONI, P. A negação do Pós Moderno e a Negação do Moderno. Caramelo, São Paulo, n. 02, p. 04-11, jun. 1991.

RIBEIRO, A. C. Vontade de ser. AU, São Paulo, n. 24, p. 84-88, jun./jul, 1989.

RIZEK, S. Cidades globalizadas e a crise das utopias urbanas. Boletim Óculum, Campinas, São Paulo, n. 15, p. 02, mar. 1998.

ROCHA, P. M. da. Casa de Concreto. Casa e Jardim, São Paulo, n. 156, p. 32-36, p. 33, jan./ 1968.

Pavilhão do Brasil na EXPO 70. Acrópole, São Paulo, n. 361, p. 13-27, maio 1969.

Depoimento. A Construção São Paulo, São Paulo, n. 1321, p. 35-36, jun., 1973.

ROCHA, P. M. da. Casa em Catanduva. AU, São Paulo, n. 08, p. 32-33, out./nov. 1986. (a)

Morar na era Moderna. Projeto, São Paulo, n. 94, p. 99, dez. 1986. (b)

Visibilidade e clareza da Forma. Projeto, São Paulo, n. 175, p. 54-57, jun. 1994. (a)

Olhando para as paisagens. Projeto. São Paulo, n. 175, p. 58-60, jun. 1994. (b)

. Virtudes de uma casa. Projeto. São Paulo, n. 175, p. 61-62, jun. 1994. (c)

Tentamos sempre preservar a integridade do projeto, enfrentando a vertigem do mercado. [Entrevista concedida a Fernando Serapião e Silvério Rocha junto de integrantes das equipes: Ricoy Torres e Colonelli, Piratininga Arquitetos, MMBB Arquitetos e Metro Arquitetos]. Projeto, São Paulo, n. 275, p. 06-11, jan. 2003.

ROCHA, S. Oca do Ibirapuera, a redescoberta da arquitetura. Projeto, São Paulo, n. 243, p. 66-73, maio 2000. 
ROLNIK, R. As barreiras de São Paulo. Revista da Folha, São Paulo, ano 09, n. 468, p. 16, maio 2001.

SANT'ANNA, A. C. Jr. Impressões de um observador participante. AU, São Paulo, n. 27, p. 74-82, dez. 1989/jan. 1990.

Strada Novissima. Projeto, São Paulo, n. 143, p. 55-56, jul. 1991. (a)

Concurso Paço em Osasco. AU, São Paulo, n. 37, p. 88-99, ago./set. 1991. (b)

SANTOS, C. R. dos. Morada Paulista. AU, São Paulo, n. 48, p. 31-47, jun./jul. 1983.

O concurso público para a igreja de Cerqueira César. Projeto, São Paulo, n. 128, p. 68-75, dez. 1989.

Novíssimos Arquitetos. Projeto, São Paulo, n. 143, p. 54-73, jul. 1991.

SEGAWA, H. (Org.). Duas entrevistas inéditas de Vilanova Artigas. [Entrevistas de Vilanova Artigas concedidas a Aracy Amaral e Lena Coelho Santos]. Projeto. São Paulo, n. 109, p. 91102, abr. 1988.

abr./maio 1990.

A Câmara de Brasília: a fênix abrindo as asas? Projeto, São Paulo, n. 131, p. 41-47, Pavilhão do Brasil em Sevilha: deu em vão. Projeto, São Paulo, n. 138, p. 34-39, fev. 1991.

Arquitetura modelando a paisagem. Projeto, São Paulo, n. 183, p. 32-47, mar. 1995.

SERAPIÃO, F. Complexa concepção construtiva é ocultada pela simplicidade volumétrica. (Clínica de Odontologia). Projeto, São Paulo, n. 248, p. 76-81, out. 2000.

Debate: A opinião dos críticos. A Arquitetura Brasileira evoluiu apesar das dificuldades impostas pela globalização. Projeto, São Paulo, n. 251, p. 42-47, jan. 2001. (a)

Anos 90: Bastante Construção, muita arquitetura e nenhum milagre. Projeto, São Paulo, n. 251, p. 60-63, jan. 2001. (b)

. Pavilhão suspenso acolhe espaço para cidadania em região carente. (Poupatempo Itaquera, Paulo M. Rocha e MMBB). Projeto, São Paulo, n. 253, p. 62-66, mar. 2001. (c)

Meninos do Brasil.com.br. Especial Nova Arquitetura Brasileira. Projeto, São Paulo, n. 263 , p. $34-97$, jan. 2002. (a)

Generosa, edificação inspira-se na cidade para gerar convivência. (Centro comercial e de serviços, Núcleo de Arquitetura). Projeto, São Paulo, n. 268, p. 62-66, jun. 2002. (b)

Apoiado em quatro pilares volume utiliza estrutura surpreendente. (Casa Mello, MMBB). Projeto, São Paulo, n. 270, p. 64-68, ago. 2002. (c)

Ripado e massa bruta dão ar contemporâneo a antiga ruína de concreto. (Museu de microbiologia, Márcio Kogan). Projeto, São Paulo, n. 276, p. 56-61, fev. 2003. (a) 
Transparência e relação com terreno revigoram essência da escola paulista. (Casa Mariante, MMBB). Projeto, São Paulo, n. 282, p. 34-41, ago. 2003. (b)

Paralelos (e transversais) na história da casa paulista. Projeto, São Paulo, n. 287, p. 26-37, jan. 2004. (a)

Escolas FDE. Estrutura pré-fabricada marca nova etapa de escolas paulistas. Projeto, São Paulo, n. 296, p. 58-75, out. 2004. (b)

Escola Ataliba Leonel. Brises de Madeira e obras de arte dão destaque à quadra.

Projeto, São Paulo, n. 314, p. 54-59, abr. 2006. (a)

Especial Paulo Mendes da Rocha. Consagração, no escritório virtual: do MuBE ao

Pritzker. Projeto, São Paulo, n. 316, p. 52-55, jun. 2006. (b)

SILVA, V. Idéias em Evolução. Projeto, São Paulo, n. 113, p. 26-33, ago. 2003.

SOUZA, M. de. Paulo Mendes da Rocha - Sutis pegadas do bicho arquiteto. AU, São Paulo, n. 79, p. 63-69, ago./set. 1998. (a) 1998. (b)

Centro Cultural FIESP - Estrutura Parasita. AU, São Paulo, n. 79, p. 72-76, ago./set.

SPEAKS, M. Tales from the Avant-Garde: How the new Economy is trasforming Therory and Practice. Architectural Record, n. 12, p. 74-78, dez. 2000.

STOLARSKI, A.; VIÉGAS, F. F.; RODRIGUES, F. N.; PRATA, J. M.; ASQUINO, M. S. Publicações: as revistas Desenho e Ou... Caramelo, São Paulo, n. 06, p. 23-30, 1993.

TEIXEIRA, C; BAVA, C. Dos anos 50 aos 90. Casa Baeta. Arquitetura \& Construção, São Paulo, n. 03, p. 28-37, mar. 1998.

TELLES, S. S. O frágil cotidiano. AU, São Paulo, n. 04, p. 34-7, fev. 1986. Museu da Escultura. AU, São Paulo, n. 32, p. 44-51, out./nov. 1990.

jun./jul. 1995.

Paulo Mendes da Rocha. [Documento]. AU. São Paulo, ano 10, n. 60, p. 69-81,

TERMINAL requalifica região da Lapa. Cimento Hoje. Informativo ABCP. São Paulo, n. 48, p. 05, mar. 2004.

THOMAZ, D. Sevilha no MASP como desfile de prêt-a-porter. Caramelo, São Paulo, n. 02, p. 18-20, jun. 1991.

Vilanova Artigas. [Documento]. AU, São Paulo, n. 50, p. 77-90, out./nov. 1993.

TRELCAT, S. “Brazil Builds", le retour. L'Architecture D'Aujourd'hui, Paris, n. 359, p. 4045, jul./ago. 2005

URBAN Bus Station Parque D. Pedro II. $A+U$, Tóquio, n. 341, p. 124-9, fev. 1999. 
URBINATI, A. Com simplicidade formal, pavilhão adapta-se às condições do local. Projeto, São Paulo, n. 249, p. 70-2, nov. 2000.

VIEIRA FILHO, C. A. Vilanova Artigas e a arquitetura paulista. Tendências atuais da arquitetura brasileira: Vilanova Artigas 1915/1985, São Paulo, ed. esp., p. 53-57, 1985.

VILlELA, A. H.; TONE, B.; ZANETTI, M.; MACHADO, T. Espaços da FAU. Caramelo, São Paulo, n. 10, p. 74-91, 1998.

WEISSEMBACH, V. (Ed.). Muita construção, alguma arquitetura, quem sabe um milagre. Projeto, São Paulo, n. 129, p. 67, jan./fev. 1990.

(Ed.). Guaraciaba. Parque combate degradação com mais lazer. Projeto, São Paulo, n. 139, p. 91, mar. 1991.

WILHELM, R.; POPOUTCHI, I.; PERRONE, R.; Arquitetura do Possível e o Possível da Arquitetura. Módulo, Rio de Janeiro, n. 71, p. 50-52, 1982.

WOLF, J. Exercício da Modernidade. AU, São Paulo, n. 08, p. 26-33, out./nov. 1986. 1988. Escola Paulista: uma pedra no caminho. AU, São Paulo, n. 17, p. 49-69, abr./maio Cerqueira César: o lugar da celebração. $A U$, São Paulo, n. 27, p. 68-73, dez. 1989/jan. 1990. 1997. Campo Limpo Uma catedral na periferia. $A U$, São Paulo, n. 74, p. 104-106, out./nov. Geração'90. AU, São Paulo, n. 80, p. 71-79, out./nov. 1998.

YURGEL, M. Arquitetura paulista - 1952/92. Quarenta anos de contribuição dos arquitetos formados na FAUUSP. Sinopses, São Paulo, número especial, p. 124-9, 1993.

ZARDINI, M. Skin, Wall, Facade. Lotus, Milano, n. 82, p. 39-50, 1994.

ZEIN, R. V. Arquiteturas brasileiras e outras oposições. Projeto. São Paulo, n. 50, p. 33, abr. 1983. (a) jul. 1983. (b)

As tendências e as discussões do pós-Brasília. Projeto. São Paulo, n. 53, p. 75-85, Nos últimos anos, surgem os novos caminhos e tendências. Projeto. São Paulo, n. 53, p. $86-126$, jul. 1983. (c)

A obra do arquiteto. Tendências atuais da arquitetura brasileira: Vilanova Artigas 1915/1985, São Paulo, ed. esp., p. 33-45, 1985.

Da necessidade dos Rótulos. Projeto, São Paulo, n. 175, p. 72-74, jun. 1994.

Crítica de arquitetura: algumas provas de sua não-inexistência. Projeto, São Paulo, n. 267, p. 26-8, maio 2002. 


\section{Artigos Eletrônicos}

ANELLI, R. L. S. A Urbanidade do subsolo. Projeto de Arquitetura da Garagem Trianon, do Escritório MMBB. São Paulo, 1996-99. Arquitextos n. 061. Portal Vitruvius. Disponível em: <http://www.vitruvius.com.br/arquitextos/arq061/arq061_03.asp>. mar. 2004. Acesso em: 29 jun. 2006.

BAHIA, T. Ausência e Presença arquitetônica na cidade contemporânea. Portal Vitruvius. Disponível em: <http://www.vitruvius.com.br/arq000/esp248.asp>. ago. 2004. Acesso em: 06 jun. 2005.

BRAGA, M. MMBB arquitetos. ARQ, Santiago, n. 51, p. 22-27, jul. 2002. Scielo.cl. Disponível em: <http://www.scielo.cl/pdf/arq/n51/art09.pdf>. jul. 2002. Acesso em: 23 jan. 2009.

BUCCI, A. Pedra e Arvoredo. SPBR. Disponível em: <http://www.spbr.arq.br/Dart.htm〉. 2002. Acesso em: 12 set. 2007.

BUCCI, A. et. al. Garagem Trianon. SPBR. Disponível em:

<http://www.spbr.arq.br/projetos/trianon/trianon.htm> 1996. Acesso em: 29 ago. 2007.

Centro de Arte Corpo. SPBR. Disponível em:

<http://www.spbr.arq.br/projetos/grupocorpo>. 2001. Acesso em: 15 ago. 2007.

BUCCI, A.; PUNTONI, A. Modernização do Conjunto Desportivo do Ibirapuera. SPBR.

Disponível em: <http://www.spbr.arq.br/projetos/ibirapuera.htm>. 2003. Acesso em: 15 ago. 2007.

CAVALCANTI, L.; LAGO, A. C. Ainda Moderno? Arquitetura Brasileira Contemporânea. Arquitextos n. 066. Portal Vitruvius. Disponível em:

<http://www.vitruvius.com.br/arquitextos/arq066/arq066_00.asp>. 2005. Acesso em: 09 jun. 2006.

COENEN, J. Meus encontros com Paulo Mendes da Rocha. Arquitextos n. 001. Portal Vitruvius. Disponível em: 〈http://www.vitruvius.com.br/arquitextos/arq001/arq001_02.asp〉. jun. 2000. Acesso em: 01 ago. 2008.

COMISSÃO Julgadora do Concurso Público Nacional Reconversão Urbana do Largo da Batata. São Paulo, 13 de maio de 2002. Institucional n. 037. Portal Vitruvius. Disponível em: <http://www.vitruvius.com.br/institucional/inst37/inst037_ata.asp>. maio 2002. Acesso em: 22 out. 2007.

DAL CO, F. Paulo Mendes da Rocha - Pritzker Prize 2006. Arquitextos n. 071. Portal Vitruvius, Disponível em: 〈http://www.vitruvius.com.br/arquitextos/arq071/arq071_00.asp〉. 2006. Acesso em: 29 jun. 2006.

FARIA, J. de. Traços renovados. Portal Veja SP. Disponível em: $<$ http://vejasaopaulo.abril.com.br/revista/vejasp/edicoes/2007/m0128182.html>. 2007. Acesso em: 29 ago. 2007. 
FRANCO, F. M. de; MOREIRA, M.; BRAGA, M.; Corredor Sabará. MMBB. Disponível em: <http://www.mmbb.com.br >. 1994. Acesso em: 29 ago. 2007.

FUÃO, F. F. Brutalismo, a última trincheira do movimento moderno. Arquitextos n. 036.

Portal Vitruvius. Disponível em:

<http://www.vitruvius.com.br/arquitextos/arq000/esp036.asp>. Acesso em: 29 jun. 2006.

GAMA, M. A herança moderna da arquitetura. Sinapse n. 64. Folha Online. Disponível em: <http://www1.folhauol.com.br/folha/sinapse/ult1063u585.shtml>. Acesso em: 10 abr. 2008.

GIMENEZ, L. E. As quatro escolas do FDE em Campinas. Arquitextos n. 064. Portal Vitruvius. Disponível em: <http://www.vitruvius.com.br/arquitextos/arq064/arq064_2.asp>. 2005. Acesso em: 21 ago. 2007.

GIOIA, M. Arquitetura do Presente. Folha de São Paulo, São Paulo, 06 de novembro de 2006. ADEMIRJ. Disponível em: <http://ademi.webtexto.com.br>. nov. 2006. Acesso em: 29 ago. 2007.

GUERRA, A. (Ed.). Depoimentos de uma geração migrante. Arquitextos n. 030. Portal Vitruvius. Disponível em: 〈http://www.vitruvius.com.br/arquitextos/arq030/arq030_00.asp〉. 2002. Acesso em: 29 jun. 2006.

Casa Mariante em Aldeia da Serra, projeto do MMBB Arquitetos. Arquitextos n. 225. Portal Vitruvius. Disponível em:

<http://www.vitruvius.com.br/arquitextos/arq000/esp225.asp>. nov. 2003. Acesso em: 29 jun. 2006.

Quatro projetos do grupo MMBB. Arquitextos n. 056. Portal Vitruvius. Disponível em: <http://www.vitruvius.com.br/arquitextos/arq056/arq056_02.asp>. 2004. Acesso em: 07 nov. 2007.

Arquitetura e Estado no Brasil. (Editorial). Arquitextos n. 064. Portal Vitruvius. Disponível em: <http://www.vitruvius.com.br/arquitextos/arq064/arq064_00.asp>. 2005. Acesso em: 29 jun. 2006.

GUIMARAENS, C. Arquitetura Brasileira após-Brasília: Redescobertas? Portal Vitruvius. Disponível em: <http://www.vitruvius.com.br/ac/ac010/ac010.asp>. fev. 2003. Acesso em: 06 jun. 2005.

LARA, F. L. Espelho de fora: a arquitetura brasileira vista do exterior. Arquitextos n. 012. Portal Vitruvius. Disponível em:

<http://www.vitruvius.com.br/arquitextos/arq000/esp012.asp>. 2000. Acesso em: 29 jun. 2006.

136 Arquiteturas Brasileiras. Portal Vitruvius. Disponível em:

<http://www.vitruvius.com.br/arq022/arq22_00.asp>. mar. 2002. Acesso em: 06 jun. 2005.

LEONÍDIO, O. De arquiteturas e ideologias. O esquema arquitetura carioca versus arquitetura paulista. Arquitextos n. 079. Portal Vitruvius. Disponível em: <http://www.vitruvius.com.br/arquitextos/arq079/arq079_02.asp>.jan. 2003. Acesso em: 25 abr. 2008. 
LIMA, Z. R. M. de A. Geração Migrante - Migrar, verbo transitivo e intransitivo. Arquitextos n. 164. Portal Vitruvius. Disponível em:

<http://www.vitruvius.com.br/arquitextos/arq000/esp164.asp>. jan. 2003. Acesso em: 21 ago. 2007.

NOBRE, A. L. A falta que nos faz. A Crítica e Arquitetura no Brasil. Arquitextos n. 002. Portal Vitruvius. Disponível em:

<http://www.vitruvius.com.br/arquitextos/arq002/arq002_02.asp>. Acesso em: 09 jun. 2006.

MMBB. Portal Vitruvius. Disponível em:

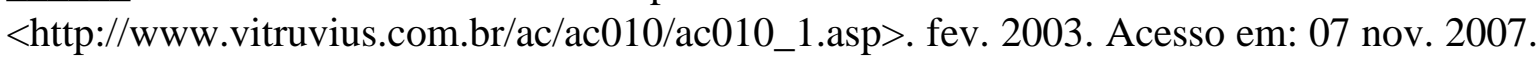

PUNTONI, A. Sede do Grupo Corpo. GrupoSP. Disponível em:

$<$ http://www.gruposp.arq.br/sitio_projetos/0108_grupo_corpo/0108.htm>. 2001. Acesso em: 29 ago. 2007.

Concurso HabitaSampa - Projetos para locação social. Isntitucional n. 77. Portal Vitruvius. Disponível em: 〈http://www.vitruvius.com.br/institucional/inst77_02_08.asp>. 2004. Acesso em: 21 ago. 2007.

RECAMÁN, L. A. A unidade Cruel - a arquitetura paulista explicada aos ingleses. Trópico. <http://p.php.uol.com.br/tropico/textos/350,1.shl>. 2000. Acesso em: 29 ago. 2007.

RECAMÁN, L. Velhos e Novos Conflitos - a cidade de São Paulo está se destruindo e reconstruindo pela quinta vez em um século. Trópico.

<http://p.php.uol.com.br/tropico/textos/814,1.shl>. 2002. Acesso em: 29 ago. 2007.

Curvas e Retas não alcançam as cidades no Brasil. Arquitextos n. 394. Portal Vitruvius. Disponível em: <http://www.vitruvius.com.br/arquitextos/arq000/esp394.asp>. 2006. Acesso em: 25 abr. 2008.

SALES, P. R. M. Operações Urbanas em São Paulo: crítica, plano e projetos. Parte 2 Operação Urbana Faria Lima: relatório de avaliação crítica. Arquitextos n. 300. Portal Vitruvius. Disponível em: <http://www.vitruvius.com.br/aquitextos/arq000/esp300.asp >. abr. 2005. Acesso em: 18 out. 2007.

SOARES, L. M.; URSINI, M. L.; SOUZA, S. L. S.; Concurso Público de Arquitetos para Modernização do Conjunto Desportivo do Ibirapuera. Institucional n. 56. Portal Vitruvius. Disponível em: <http://www.vitruvius.com.br/institucional/inst56/inst56_02.asp>. 2003. Acesso em: 21 ago. 2007.

Memorial do Concurso HabitaSampa - Projetos para Locação Social. Institucional n. 77. Portal Vitruvius. Disponível em: <http://www.vitruvius.com.br/institucional/inst77/inst77_02_04.asp>. 2004. Acesso em: 21 ago. 2007.

SPERLING, D. Museu Brasileiro da Escultura, utopia de um território contínuo. Arquitextos n. 018. Portal Vitruvius. Disponível em: <http://www.vitruvius.com.br/arquitextos/arq018/arq018_02.asp>. 2001. Acesso em: 12 set. 2007. (a) 
Arquitetura como discurso. O pavilhão brasileiro de Osaka de Paulo Mendes da

Rocha. Arquitextos n. 038. Portal Vitruvius. Disponível em:

$<\mathrm{http}: / /$ www.vitruvius.com.br/arquitextos/arq038/arq038_03.asp>. 2001. Acesso em: 12 set.

2007. (b)

VILARIÑO, M. C. do et. al. Concurso Público Nacional Reconversão Urbana do Largo da Batata. Institucional n. 037. Portal Vitruvius. Disponível em:

$<$ http://www.vitruvius.com.br/institucional/inst37/inst037_02.asp>. 2002. Acesso em: 10 abr. 2008 .

XAVIER, D. Aos vencedores as Batatas. Minha Cidade n. 049. Portal Vitruvius. Disponível em: <http://www.vitruvius.com.br/minhacidade/mc049/mc049.asp>. 2002. Acesso em: 21 Ago. 2007.

ZEIN, R. V. Arquitetos de SP: breve panorama de uma nova geração. Disponível em:

<http://rvzein.googlepages.com/seminariodedoctorado,unr2> 2000. Acesso em: 18 out. 2007.

IV Bienal Ibero-Americana: ampliando intercâmbios. Arquitextos n. 052. Portal

Vitruvius. Disponível em: <http://www.vitruvius.com.br/arquitextos/arq052/arq052_00.asp>. 2004. Acesso em: 09 jun. 2006.

Artigos de jornais

FOLGATO, M. A rica e fina arquitetura paulistana. O Estado de São Paulo. São Paulo, 31 ago. 2003. Caderno Cidades, p. 1.

SCHWARZ, R. Fim de Século: Incompleto, o processo de modernização provou ser ilusório. Folha de São Paulo. São Paulo, 04 dez. 1994. 